UNIVERSIDADE DE SÃO PAULO

FACULDADE DE EDUCAÇÃO

ANA BEATRIZ FELTRAN MAIA

O apostolado de Ernesto de Souza Campos:

modelos, projetos e espaços universitários (1900-1937)

São Paulo 


\title{
O apostolado de Ernesto de Souza Campos: modelos, projetos e espaços universitários (1900-1937)
}

\author{
Versão corrigida \\ (Versão original encontra-se na unidade que aloja o Programa de Pós-graduação)
}

Tese apresentada à Faculdade de Educação da Universidade de São Paulo para obtenção de título de Doutora em Educação.

Área de concentração: História da Educação e Historiografia

Orientador: Prof. Dr. Bruno Bontempi Júnior

São Paulo 
AUTORIZO A REPRODUÇÃO E DIVULGAÇÃO TOTAL OU PARCIAL DESTE TRABALHO, POR QUALQUER MEIO CONVENCIONAL OU ELETRÔNICO, PARA FINS DE ESTUDO E PESQUISA, DESDE QUE CITADA A FONTE.

Catalogação na Publicação

Serviço de Biblioteca e Documentação

Faculdade de Educação da Universidade de São Paulo

37(092) Maia, Ana Beatriz Feltran

M217a O apostolado de Ernesto de Souza Campos: modelos, projetos e espaços universitários (1900-1937) / Ana Beatriz Feltran Maia; orientação Bruno Bontempi Júnior. São Paulo: s.n., 2017.

$162 \mathrm{p}$.

Versão corrigida

Tese (Doutorado - Programa de Pós-Graduação em Educação. Área de Concentração: História da Educação e Historiografia) - Faculdade de Educação da Universidade de São Paulo.

1. Campos, Ernesto de Souza, 1882-1970 2.

Universidade 3. Cidades universitárias I. Bontempi Júnior, Bruno, orient. 
Nome: MAIA, Ana Beatriz Feltran

Título: O apostolado de Ernesto de Souza Campos: modelos, projetos e espaços universitários (1900-1937).

Tese apresentada à Faculdade de Educação da Universidade de São Paulo para obtenção de título de Doutora em Educação, na área de concentração História da Educação e Historiografia.

Aprovada em:

Banca Examinadora

Prof. Dr.:

Instituição:

Julgamento:

Prof. Dr.:

Instituição:

Julgamento:

Prof. Dr.:

Instituição:

Julgamento:

Prof. Dr.:

Instituição:

Julgamento:

Prof. Dr.:

Instituição:

Julgamento: 
Ao Deus do Tempo, força motriz da História Aos meus pais, fontes da vida 


\section{AGRADECIMENTOS}

Em primeiro lugar, agradeço a Deus por todas as bênçãos concedidas e pela permissão de realizar este trabalho.

Ao meus pais, irmãos e família, pelo carinho, força, incentivo e apoio em todos os momentos.

A Bruno Bontempi Júnior, pela orientação generosa e atenta, e por compartilhar comigo seu interesse e conhecimentos a respeito da história do ensino superior.

Ao CNPq, pelo auxílio financeiro indispensável para a realização da pesquisa.

Aos professores da banca de exame de qualificação, André Mota e Roni Menezes, pelas contribuições preciosas à finalização da tese. A todos professores que foram responsáveis pela minha formação acadêmica nos cursos de História, Pedagogia e Pós Graduação, que contribuíram direta ou indiretamente para que esta obra fosse possível.

Ao professor Noah Sobe e a Loyola University Chicago, pela recepção gentil, contribuições e condições necessárias para a realização da pesquisa documental e bibliográfica feita nos Estados Unidos. A Barbara Grasser, que tornou minha estada possível, pelo apoio, carinho e exemplo de dedicação ao próximo.

Aos funcionários das instituições visitadas para a pesquisa, pelo auxílio e disposição que foram preponderantes para que a pesquisa se realizasse. Em especial, à família Malta Campos e aos funcionários da Fazenda Santa Maria do Monjolinho, por terem me recebido generosamente para a investigação no acervo pessoal de Ernesto de Souza Campos.

Aos companheiros e professores do grupo de pesquisa "Intelectuais da educação brasileira: formação, ideias e ações”, pelas contribuições nas jornadas de estudos.

Aos amigos que compartilharam comigo os momentos de dificuldades e de conquistas durante o processo de pesquisa, doando afeto e palavras de incentivo que foram de suma importância para que o trabalho se realizasse. Em especial, agradeço a Moriane Tardioli, Camila Reichmann, Amanda Florêncio, Jaire Feltran, Emília Moussi, Edna Pimentel, Márcio Shimomaebara e José Carlos Epifânio por ajudarem, com palavras e ações, a conclusão do trabalho e meu aprimoramento como ser humano. 
"Quase tudo o que sabemos de outrem é de segunda mão. Quando um homem se confessa, ele defende sua causa. Se o observarmos, veremos que não está só: sua apologia está antecipadamente preparada” (YOURCENAR, 1980, p.31).

"Eu mesmo já os tenho apontado[, os exemplos de universidades] às dezenas, em várias ocasiões, e hei de citá-los ainda em outras, para documentação do que disser, sempre que me sobejarem tempo e ocasião para prestar meu concurso, desvalioso mas entusiástico, pequenino mas infatigável, pobre de ideias mas rico de energia para o apostolado a que espontaneamente me atirei, não para ostentar bordados de marechal que os não almejo, antes para ocupar o mais modesto, o mais trabalhoso dos postos em campanha tão cheia de elevação e de nobreza, como essa em que se acham empenhadas figuras das mais brilhantes e aprimoradas da nossa terra. Nestas lides, ninguém pense nem procure esperar recompensas que não sejam as de sua própria consciência, modelando o seu espírito na lição admirável de Vieira: 'O prêmio das ações honradas, elas o têm em si e o levam logo consigo; nem tarda, nem espera requerimentos, nem depende de outrem, são satisfação de si mesmo. No dia em que fizestes vos satisfizestes'. Rerum honestarum pretium in ipsis est, diziam os que falavam melhor língua. Pouco importa que as grandes realizações que sonhamos venham agora ou não sejam para o nosso tempo, se já nos satisfaz a ajuda o preparo do ambiente que as há de consagrar para o futuro” (CAMPOS, 1938a, p. 10). 


\section{RESUMO}

MAIA, Ana Beatriz Feltran. O apostolado de Ernesto de Souza Campos: modelos, projetos e espaços universitários (1900-1937). 2017. 162f. Tese (Doutorado em Educação) - Faculdade de Educação, Universidade de São Paulo, São Paulo, 2017.

A pesquisa tem por objetivo apresentar e analisar a trajetória intelectual de Ernesto de Souza Campos, engenheiro, professor catedrático da Faculdade de Medicina da Universidade de São Paulo e especialista em ensino superior, entre 1900 e 1937. Esse período compreendeu suas formações acadêmicas, a inserção profissional nos campos da engenharia, medicina e arquitetura, viagens ao exterior e aproximação com a filantropia científica da Fundação Rockefeller, tanto quanto os primeiros trabalhos como especialista em projeção de estruturas e espaços universitários e o desenvolvimento do "apostolado" pela universidade, engajamento intelectual pela causa da educação superior como local de pesquisa científica, no momento de criação das primeiras universidades e cidades universitárias brasileiras, especificamente a Universidade de São Paulo (USP) e a Universidade do Brasil (UB). Como base teórico-metodológica, partimos da noção de intelectual de Bobbio (1997) e Vieira (2011), de campo científico de Bourdieu (2004) e das noções de apropriação e representação de Chartier (2002), que filiam nosso trabalho à História dos Intelectuais e à História Cultural. Por meio da investigação, podemos afirmar que Ernesto de Souza Campos foi personagem relevante no processo de construção do prédio da Faculdade de Medicina e na campanha pela universidade ocorrida a partir de meados da década de 1920, assim como na criação dos projetos universitários da USP e da UB na década de 1930, tanto em seu aspecto “espiritual”, ou seja, da concepção de universidade, quanto em seu aspecto material, nos planos das cidades universitárias. Mediante seu "apostolado", Souza Campos contribuiu para a apropriação de aspectos do modelo universitário norte-americano durante os primeiros anos da Faculdade de Medicina, USP e UB, compondo o que nomeou como conceito brasileiro de universidade.

Palavras-chave: Ernesto de Souza Campos. Universidade. Cidade universitária 


\begin{abstract}
MAIA, Ana Beatriz Feltran. The apostolate of Ernesto de Souza Campos: models, projects and university spaces (1900-1937). 2017. 162f. Thesis (Doctorate in Education) - Faculty of Education, University of Sao Paulo, Sao Paulo, 2017.

The research aims to present and analyze the intellectual trajectory of Ernesto de Souza Campos, an engineer, professor at School of Medicine of the University of Sao Paulo and specialist in higher education, between 1900 and 1937. This period comprised his academic formations, professional insertion in the fields of engineering, medicine and architecture, travelings abroad and approach to the scientific philanthropy of the Rockefeller Foundation, as well as his first works like a specialist in the projection of structures and university spaces and the development of the "apostolate" by the university, intellectual engagement for the cause of higher education as a place of scientific research, at the time of the creation of the first universities and Brazilian campus, specifically the University of Sao Paulo (USP) and the University of Brazil (UB). As a theoretical-methodological basis, we have used Bobbio's (1997) and Vieira's (2011) intellectual notion, Bourdieu's (2004) scientific field concept and Chartier's (2002) notions of appropriation and representation, which link our work to the History of Intellectuals and Cultural History. Through the investigation, we can affirm that Ernesto de Souza Campos was a relevant character for the construction of the School of Medicine and for the university campaign that began in the mid-1920s, as well as in the creation of the university projects of USP and UB in the 1930s, both in their "spiritual" aspect, that is, of the conception of university, and in its material aspect, in the plans of university campus. Through his "apostolate", Souza Campos contributed to the appropriation of aspects of the American university model during the first years of the School of Medicine, USP and UB, composing what he named as the Brazilian concept of university.
\end{abstract}

Keywords: Ernesto de Souza Campos. University. University campus 


\section{LISTA DE SIGLAS}

ABC Academia Brasileira de Ciências

ABE Associação Brasileira de Educação

CAOC Centro Acadêmico Oswaldo Cruz

CNE Conselho Nacional de Educação

Co Conselho Universitário

COPU Comissão de Organização do Plano da Universidade

EUB Estatuto das Universidades Brasileiras

EUA Estados Unidos da América

FAU Faculdade de Arquitetura e Urbanismo

FFCL Faculdade de Filosofia, Ciências e Letras

FMCSP Faculdade de Medicina e Cirurgia de São Paulo

IEB International Education Board

IHB International Health Board

IHC International Health Commission

IHD International Health Division

IDORT Instituto de Organização Racional do Trabalho

OESP O Estado de S. Paulo

PD Partido Democrático

PNE Plano Nacional de Educação

PRP Partido Republicano Paulista

RAC Rockefeller Archive Center

S. S. Serviço Sanitário

UB Universidade do Brasil

URJ Universidade do Rio de Janeiro

USP Universidade de São Paulo 


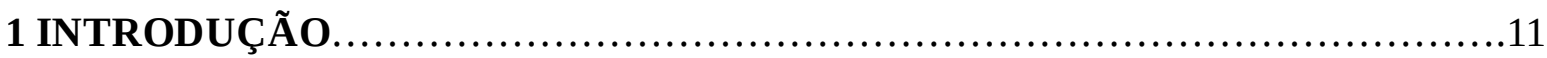

2 FORMAÇÕES ACADÊMICAS E SUAS REPRESENTAÇÕES SOCIAIS NA TRANSFORMAÇÃO DO ESPAÇO URBANO: O SENTIDO DE MISSÃO PELA

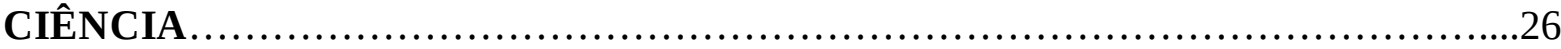

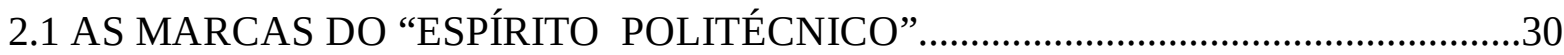

2.2 CONVERSÃO À "MÍSTICA MÉDICA”..................................................................40

2.3 DIÁLOGOS COM A ARQUITETURA E EMBATES COM A "MISSÃO SOCIAL DO ARQUITETO"...............................................................................................

3 INVESTIDURA DA MISSÃO: A REFERÊNCIA DO MODELO UNIVERSITÁRIO NORTE-AMERICANO E O APOSTOLADO PELA

UNIVERSIDADE .55

3.1 NUANCES DA APROXIMAÇÃO COM A FUNDAÇÃO

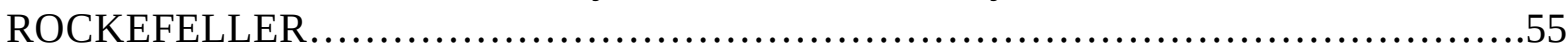

3.1.1 Viagem aos Estados Unidos em tempos de crise institucional...........................64

3.1.2 Disputas e "desencaixe" no retorno à São Paulo.........................................70

3.2 CONSTRUIR É MATERIALIZAR O MODELO....................................78

3.2.1 Das viagens da comissão de estudos à cátedra .........................................80

3.2.2 O Escritório de Obras e a concretização dos planos: o majestoso prédio da medicina

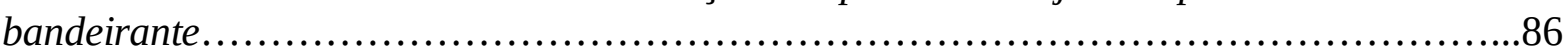

3.3 POR UMA UNIVERSIDADE EM SÃO PAULO: DA CAMPANHA À

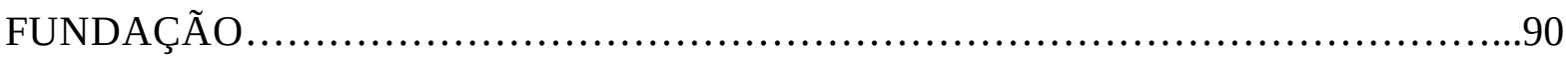

3.3.1 O "espírito de uma verdadeira organização universitária"..............................................92

3.3.2 A questão universitária na Faculdade de Medicina......................................99

3.3.3 O debate sobre a universidade no Rotary Club de São Paulo.............................103

3.3.4 Iniciativas rumo à universidade .........................................................110

3.3.5 Da revolução ao decreto: o ambiente da Faculdade de Medicina e a fundação da Universidade de São Paulo....................................................................115

4 CONSOLIDAÇÃO DA OBRA: ESPÍRITO E CORPO DA UNIVERSIDADE ......122

4.1 FORMAÇÃO DO “ESPÍRITO UNIVERSITÁRIO”: A FFCL ..........................122

4.1.1 Fundação da Faculdade de Filosofia, Ciências e Letras: contextos e contrapontos.

4.1.2 Contestações ao projeto da FFCL durante a diretoria de Ernesto de Souza

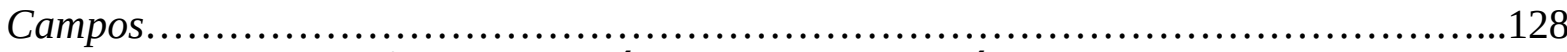

4.2 MATERIALIZAÇÃO DO “ESPÍRITO UNIVERSITÁRIO”: A CIDADE

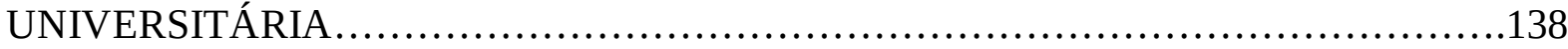

4.2.1 O caso da USP: a primeira fase dos

planos.

4.2.2 Projeto educacional versus projeto arquitetônico: disputas no caso da

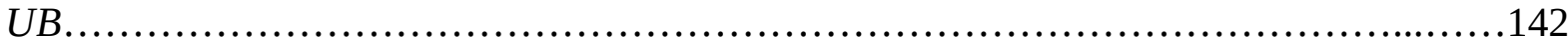

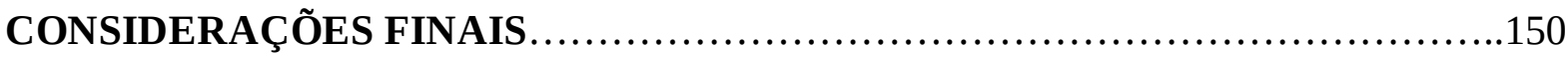

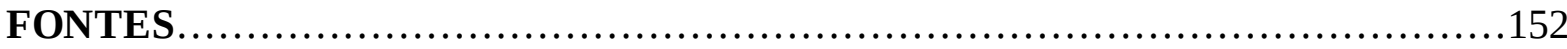

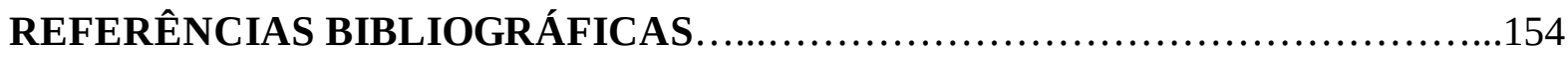




\section{INTRODUÇÃO}

Personalidade mitificada por uns e eclipsada por outros, Ernesto de Souza Campos tem seu nome vinculado à história da Universidade de São Paulo e ao ensino superior brasileiro por sua trajetória acadêmica como professor catedrático da Faculdade de Medicina, escritor da monumental História da Universidade de São Paulo (1954) e de livros sobre a história do ensino superior, assim como por trabalhos ligados ao plano da cidade universitária da Universidade do Brasil e do projeto e execução da cidade universitária Armando de Salles Oliveira, na capital paulista. Engenheiro e médico, produziu, além de relatórios técnicos e pesquisas acadêmicas, obras de ensaio histórico, poemas e artigos em jornais sobre assuntos diversos. Durante as décadas de 1920 e 1930, dedicou seu pensamento à causa da universidade, tornando-a seu “apostolado”, engajando-se no debate público pela criação de "verdadeiras universidades” embasadas na pesquisa científica e debruçando-se com afinco na organização e formação do "espírito” e do “corpo” da universidade -- a Faculdade de Filosofia, Ciências e Letras e a cidade universitária, respectivamente. Homem da virada do século XIX para o XX, Souza Campos tinha as credenciais de erudição de seu tempo e fez da formação e da carreira acadêmica uma plataforma para cumprir sua missão como “profissional da ciência” no encaminhamento do país para a modernidade, que abarcou a atuação nas áreas médica, política e educacional ${ }^{1}$.

Percorrendo o período que parte de sua primeira formação acadêmica na Escola Politécnica, em 1900, aos trabalhos nas comissões da cidade universitária da Universidade do Brasil e da Universidade de São Paulo, até 1937, traçamos o recorte temporal desta análise. Foi nesse ínterim que Ernesto de Souza Campos ingressou nos cursos de engenharia e medicina, começou a atuar profissionalmente, fez viagens ao exterior, lecionou, pesquisou, publicou, atuou em cargos em instituições de ensino superior e planejou prédios médicos e cidades universitárias, constituindo a fase de formação de seu engajamento intelectual por meio do “apostolado” pela universidade. Em 1937, Souza Campos esteve no auge dessa missão, ao ser designado diretor da Faculdade de Filosofia, Ciência e Letras da USP e atuar concomitante

\footnotetext{
1 A presente tese integra os trabalhos desenvolvidos pelo grupo de pesquisa "Intelectuais da educação brasileira: formação, ideias e ações”, coordenado pelo Prof. Dr. Bruno Bontempi Jr. e composto por docentes e estudantes do Programa de Pós-Graduação em Educação da Faculdade de Educação da Universidade de São Paulo (FE-USP) e do Programa de Estudos Pós-Graduados em Educação: História, Política, Sociedade da Pontifícia Universidade Católica de São Paulo (PUC-SP).
} 
como especialista na projeção de estruturas e espaços voltados ao ensino superior para os governos federal e paulista.

Como amante da História, Souza Campos preservou e organizou seu arquivo pessoal. Além de contar a história de instituições de ensino superior, contou a própria, criou caminhos interpretativos e narrativas que procuraram legitimar seus esforços e legar à posteridade seus melhores anos devotados à vida científica e pública. Exatamente por essa característica, estudar o itinerário intelectual de Ernesto de Souza Campos no ensino superior brasileiro foi instigante e ao mesmo tempo desafiador. Sábio narrador, tinha a perspicácia de ressaltar e ocultar fatos e personagens. Foi preciso dissecar tramas, contextualizar ações, cruzar informações, identificar lacunas e construir pontes interpretativas para termos um perfil histórico de sua atuação e tecermos nossas reflexões e análises.

O arquivo privado de Ernesto de Souza Campos está preservado no Instituto Souza Campos, localizado no Museu Histórico da Fazenda Santa Maria do Monjolinho, em São Carlos, pertencente a família Malta Campos. O fundo conta com centenas de documentos entre álbuns, fotografias, caricaturas, objetos pessoais, condecorações, manuscritos, documentos pessoais e profissionais, cartas, recortes de jornais, revistas, esboços de edifícios e espaços públicos, bem como publicações de sua autoria, parcialmente acondicionados e classificados. Em especial, a maior parte dos documentos encontram-se arquivados por Souza Campos em livros nomeados Curriculum Vitae, sendo um conjunto composto por sete exemplares.

O número elevado de documentos, a diversidade de instituições as quais esteve ligado, a vastidão e diversificação dos registros de suas ações em diferentes âmbitos institucionais, a perceptível presença de redes políticas, sociais, profissionais e intelectuais que o ligavam a distintas esferas de atuação demonstraram, aos olhos inquiridores do historiador, tratar-se de uma personalidade de complexidade e engenho. Sua preocupação em preservar a maior parte do volume dos documentos pessoais em grandes cadernos de capa dura, em sequência cronológica, além de ter confeccionado memoriais em sua juventude e madureza, registram e apresentam um sujeito ciente de suas ações e atento à construção da própria memória no espaço público. $\mathrm{O}$ notável zelo com que Souza Campos guardou os registros de sua trajetória profissional e intelectual remete-nos à questão: como compreender esta personalidade, que se exprime por meio dos documentos e pela forma com que foram ordenados e guardados?

Assim como Priscila Fraiz (2000, p.74) refletiu sobre o arquivo privado de Gustavo 
Capanema, semelhante ao de Souza Campos justamente por ter sido organizado pelo produtor com o objetivo de dar suporte à escrita memorialística, “a construção de seu arquivo pessoal pode ser reveladora da maneira como ele constituía seu eu, sua imagem, emprestava-lhe um sentido, dava-lhe coerência e a solidificava”. Fez-se necessário, portanto, ter no horizonte da pesquisa que o corpus fundamental não só constituiu o registro das ações de Souza Campos no âmbito do ensino superior, mas capturou suas intenções, interesses pessoais e profissionais, a necessidade de dar um sentido à sua trajetória. Ele resultou da capacidade e do desejo autoral de selecionar o que mereceria ser guardado e registrado para a memória pessoal e pública. Portanto, o discurso autorreferenciado contido neste arquivo tem, simultaneamente, o valor de testemunho e autoria (FRAIZ, 2000, p. 92).

Para Fraiz (2000, p.77) a escolha do historiador por trabalhar com arquivo pessoal como corpus principal fundamenta-se na preponderância do valor informativo deste para fins históricos, em detrimento do valor de prova legal, característico dos documentos públicos. No entanto, a organicidade do acervo privado, a maneira como foi arranjado e guardado constitui valor de prova para o pesquisador, pois lhe possibilita captar do conjunto as provas de que necessita para a pesquisa e resgatar a globalidade de sua lógica de arranjo. Além da ordenação dos documentos, o arquivo privado constitui um espaço de materialização da memória do indivíduo e dos grupos a que pertence e serve como instrumento de construção do "eu” dentro da noção de indivíduo moderno, dotado de singularidades perante o coletivo. Essas singularidades não representam um sujeito coeso e coerente, mas sua multiplicidade, heterogeneidade e fragmentação, representadas nos documentos.

A escrita de si, então, torna-se lugar de produção do sujeito em busca de coerência, linearidade, sentido e consolidação da identidade. Essa prática de escrita pode evidenciar uma trajetória individual que se altera ao longo do tempo, registrar fases específicas da vida, como viagens e experiências marcantes, ou mesmo estabelecer uma temporalidade baseada na memória da vida profissional, com uma linguagem mais distante da escrita íntima, mas não menos pessoal. É essencial, assim como a necessidade de atentar para as relações do documento com o tempo e a análise do suporte material do registro, evitar a ideia ingênua de ser o registro pessoal uma verdade sobre os fatos e compreender que ele apresenta a visão e a experiência do sujeito sobre os fatos (GOMES, 2004, p. 11-19). Não se trata, portanto, de assumir uma postura de inquirição da memória e da personalidade de Souza Campos, como em um julgamento em 
busca de uma suposta "verdade absoluta” dos fatos, mas trabalhar com as potencialidades do próprio acervo, de destrinchar a memória auto produzida, de dissecar suas tramas, de compreender seus posicionamentos e seleções, de dar voz à obra de maneira a conceder o devido peso de seu engajamento dentro do tempo/espaço de suas ações, de historicizar as memórias e as publicações, compondo um quadro histórico de seu itinerário intelectual dentro do contexto da formação das universidades brasileiras.

Para contrabalancear e por vezes contrapor os registros pessoais, marcados pela experiência do sujeito, foram selecionados outros conjuntos documentais de origem institucional. Foram feitas pesquisas no Museu Histórico Prof. Carlos da Silva Lacaz, da Faculdade de Medicina da USP, no Arquivo Geral da Escola Politécnica da USP, no Centro de Pesquisa e Documentação de História Contemporânea do Brasil (CPDOC), na Welch Medical Library da Universidade Johns Hopkins e no Rockefeller Archive Center, nos Estados Unidos, além de consultas aos resumos das atas do Conselho Universitário da USP. Com base nesta documentação pública, pudemos matizar os dados obtidos junto ao arquivo privado, alinhavando as nuances entre a memória e a história da trajetória intelectual de Ernesto de Souza Campos no ensino superior brasileiro.

A seleção do corpus fundamental igualmente nos impôs problematizações de ordem temática. O grande volume de documentos e a diversidade de registros que tratavam das esferas pessoal, financeira, profissional, familiar, religiosa e cultural de Souza Campos impingiu, primeiramente, a escolha de um recorte para a coleta de dados e análise. Assim, do volume total do acervo foram selecionados os documentos que tratavam de sua atuação no ensino superior como corpus principal, levando em conta registros que poderiam adicionar dados complementares.

A opção por pesquisar seu engajamento na constituição da história do ensino superior justifica-se por sua própria identificação com o tema e consequentemente seu destacado pertencimento e empenho na formação e estudo de instituições de nível superior, o que gerou um rico fundo arquivístico. No período histórico em que o acesso à formação superior era restrito a uma parcela ínfima da sociedade, compondo uma elite ilustrada (HEINZ, 2006), Ernesto de Souza Campos foi aluno da Escola Politécnica de São Paulo e da Faculdade de Medicina e Cirurgia de São Paulo, instituições incorporadas posteriormente à Universidade de São Paulo, da qual foi docente, gestor e entusiasta. Analisando o conjunto de livros e relatórios 
feitos por Souza Campos, percebemos que suas obras sobre o ensino superior são resultados de momentos específicos de trabalhos que executou, em demandas de instituições às quais esteve ligado. Essa especificidade de motivação e produção, como respostas a questões da vivência institucional apresenta um intelectual que fala e age a partir de um "lugar de ação privilegiado", ou seja, de uma instituição de ensino superior. Somadas a essas obras, encontramos no acervo de Souza Campos e nos arquivos institucionais, registros de sua vivência em instituições de ensino superior internacionais, por exemplo, nos Estados Unidos, Canadá, em países da Europa e no Japão, assim como sua participação em debates sobre o ensino superior em espaços de sociabilidade da elite paulista, como o Rotary Club de São Paulo, publicações em revistas estudantis, como a Revista de Medicina e Revista Polytechnica, e em jornais de grande circulação como O Estado de S. Paulo.

Além disso, sua relevante participação na projeção e construção de estruturas e espaços físicos de faculdades e universidades nos remeteu a investigar as relações entre projetos de ensino superior e sua constituição material em prédios e cidades universitárias, seguindo uma lógica dos estudos das ligações entre projeto educacional e espaço, explorados em trabalhos que tratam da educação infantil ou do ensino básico, mas ainda lacunar na historiografia quanto a educação superior.

Por conta da escolha do tema que guiou nossa investigação, parte da pesquisa bibliográfica foi delineada para compreender as problematizações, os debates e os principais debatedores da questão do ensino superior brasileiro entre as décadas de 1900 e 1930, recriando a atmosfera política, ideológica e científica institucional na qual Souza Campos defendeu e imprimiu seus trabalhos. A historiografia da educação que trata do ensino superior no Brasil (CUNHA, 1980, 1989; MENDONÇA, 2000; FÁVERO, 2006) tem se concentrado na discussão do conceito de universidade e no rastreamento das diversas formas de existência dos estudos e instituições superiores no país, de acordo como mudanças de ordem política, econômica e social, e pela implantação de projetos políticos, em especial das classes dominantes. O período analisado por Cunha, Fávero e Mendonça, autores de obras referenciais sobre a questão universitária, concentra-se especialmente entre os anos 1920, momento de intensificação dos debates sobre a criação de universidades, até 1968, ano da Reforma Universitária. Nos três trabalhos, entretanto, a questão da construção das cidades universitárias e a incorporação dos princípios de modelos de ensino superior estrangeiros, em especial o 
norte-americano, nas instituições brasileiras guardam consensos e são apresentadas de forma pouco aprofundada.

Em geral, a história dos campi brasileiros tem sido contada nas pesquisas de história da arquitetura e urbanismo, referências que utilizamos para o diálogo historiográfico ao longo do texto, e especialmente quanto à construção das cidades universitárias da Universidade do Brasil e da Universidade de São Paulo. Ernesto de Souza Campos é citado em alguns trabalhos como personagem em destaque, porém sem a devida compreensão de sua matriz intelectual, da formação e engajamento na campanha pela universidade e na criação de projetos universitários. Obra de caráter inovador, que discute e analisa a cidade universitária como expressão de um projeto pedagógico, Arquitetura e Educação: câmpus universitários brasileiros (2009), do arquiteto Gelson Pinto e da historiadora da educação Ester Buffa, traz ao debate uma nova visada sobre a estrutura espacial universitária, unindo-a à história do ensino superior como objeto de pesquisa educacional.

A presente pesquisa pretende dialogar com este ponto do debate historiográfico. Ao elegermos como eixo de análise a trajetória de produção intelectual de Souza Campos no ensino superior, nos deparamos com seus trabalhos de projeção e construção do prédio da Faculdade de Medicina e com os projetos dos campi da Universidade do Brasil e na Universidade de São Paulo. Seus projetos são espelhados nas instituições norte-americanas com as quais esteve em contato, e foram criados entre as décadas de 1920 e 1930, indicando modos de apropriação que antecedem os movimentos pela modernização dos anos 1950 e 1960, identificados pela historiografia tradicional como momento de inserção do modelo de ensino superior norte-americano no Brasil. Parte importante dessa apropriação foi promovida pelo contato com a Fundação Rockefeller na Faculdade de Medicina e nas consequentes viagens ao exterior, durante a década de 1920. Em decorrência dessa aproximação, Souza Campos continuou sendo o mediador entre a Rockefeller e a Universidade de São Paulo entre os anos 1930 e 1940 (MARINHO, 2001), dando sequência à implantação de aspectos do ensino superior norte-americano na universidade. Portanto, a pesquisa tem como um dos objetivos aprofundar a compreensão das formas pelas quais os princípios constituintes do modelo norte-americano de universidade foram adotados em instituições de ensino superior brasileiras, estando inscritos nos projetos de Souza Campos, entre as décadas de 1920 e 1930. 
Estamos cientes, no entanto, que não tratamos de esgotar o assunto circunscrito à pesquisa, mas pretendemos contribuir para a historiografia da educação brasileira ao compreender os caminhos e as marcas, os traços históricos fundamentais que compuseram a trajetória de Souza Campos como intelectual que tomou para si a missão de idealizar, projetar e construir o nascente ensino universitário nacional nas primeiras décadas do século XX. Interessou-nos compreender como Ernesto de Souza Campos idealizou, defendeu e argumentou concepções de ensino superior e de universidades; como opinou, engajou-se, planejou, apropriou-se de modelos culturais estrangeiros e participou da criação e da construção de instituições de ensino superior, mostrando como seu empenho à causa das universidades e das cidades universitárias marcou a história do ensino superior nacional. Nesta chave de análise, apresentamos como Souza Campos atuou no ensino superior, especialmente nas instituições e ambientes aos quais pertenceu e se engajou, apontando como esses espaços foram transformados por meio de suas ações.

Para o desenvolvimento da pesquisa, foram necessárias a interpretação e a operação de algumas noções como ferramentas teórico metodológicas, inscritas nas tradições historiográficas da história dos intelectuais e da história cultural. Estão entre elas as noções de trajetória, intelectual, apropriação e representação. Ao analisar as principais linhas de pensamento historiográfico que conduzem os trabalhos biográficos na atualidade, Paziani (2012, p. 194) observa que:

\footnotetext{
intimamente ligada à (re)emergência dos sujeitos individuais e/ou coletivos na escrita da história [...], a aposta biográfica articula-se aos estudos culturais, principalmente os que se enveredaram, em maior ou menor grau, pela análise de trajetórias individuais. Associada também a outros dois "retornos", o da política [...] e o da narrativa [...], a biografia conquistou um lugar indiscutível na sociedade moderna através do mercado editorial, das livrarias, de programas de televisão ou dos documentários cinematográficos.
}

Na mesma senda de análise das principais tendências e impasses do gênero biográfico, Schmidt (1996, p.165-166) aponta que

os estudos biográficos recentes, embora herdeiros de uma longa tradição, apontam para problemas que estão no centro do debate historiográfico contemporâneo: as relações entre indivíduo e sociedade, entre unidade e fragmentação do social, entre narração e explicação e entre o público e o privado, para citar alguns exemplos. 
A partir dos anos 1980, a redefinição de tendências teóricas na disciplina História, com o (re)despertar da importância do sujeito frente à sociedade massificada e a procura de sua identidade individual, a dimensão da vida privada ganhou novos contornos, apoiada na crítica aos enfoques excessivamente macroestruturais, e repercutiu na produção de biografias por historiadores. Embora haja uma aproximação do gênero biográfico com o estilo literário, dada a natureza de relato e narração, a biografia histórica não perde de vista a explicação do sentido da vida do sujeito em seu contexto histórico e social, pois está assentada em pesquisas documentais intensivas e em uma variedade de fontes (SCHMIDT, 1996, p.1971-183).

De acordo com Dosse (2009), a biografia não é uma produção de caráter artístico, mas está trilhada na busca pelo verídico, baseada em fontes, para dar a possibilidade ao biógrafo de encontrar, não uma ideia de verdade generalizada sobre o indivíduo, mas um tom, um relevo na história de vida do sujeito biografado. É a operação de encontrar uma unidade no gesto que caracteriza o sujeito, porém, com alterações e modificações possíveis ao longo do período analisado, já que o significado de uma vida pode ser plural e aberto a novas interpretações. É a partir desta proposta de entrar pela singularidade do sujeito para chegar à universalidade da questão que delineamos o presente trabalho. Assim, confluímos as potencialidades do acervo pessoal de Souza Campos com a intenção de elucidar fatos, características e personagens que constituem e compõem a história do ensino superior brasileiro do início do século XX, na busca dos momentos significativos, do clima intelectual, dos lugares de memória e dos grupos nos quais Souza Campos viveu e atuou. Ao lado dos procedimentos indicados por Dosse, utilizamos como base a metodologia utilizada por Sirinelli a respeito das intersecções entre a história intelectual, cultural e política.

Conforme apontou Alves (2012), Jean-François Sirinelli dedicou seus estudos a compreender as formas de representação de grupos de intelectuais em ligação com o campo político, identificando-se como propositor de uma história cultural do político no debate historiográfico francês dos anos 1980. Procurou sintetizar

as principais ferramentas metodológicas que poderiam renovar o tratamento da pesquisa histórica sobre as temáticas relativas aos intelectuais, apontando para a escrita de uma história dos intelectuais em parâmetros distintos dos que marcaram a história das ideias tradicionalmente configurada. Procurando escapar à ênfase nos polos frequentemente tomados como explicativos das trajetórias dos intelectuais -- segundo ele, a casualidade ou a predestinação --, Sirinelli 
defendia a inserção das ideias em seu contexto social e histórico, perseguindo e avançando nas indicações de pesquisadores da história cultural na França (ALVES, 2012, p. 115).

Dessa maneira, a construção de trajetórias intelectuais tem por pressuposto "afinar a capacidade de observação do contexto histórico que se traduzem em vivências cotidianas, que marcam a sensibilidade, as escolhas, as afinidades, as aproximações e os deslocamentos”, buscando reconstituir o "indivíduo inserido em múltiplas dimensões espaço-temporais” . Não se trata, portanto, da "simples menção às etapas de vida e formação escolar [do indivíduo], mas a tentativa de apreensão de como se foi construindo 'o intelectual' em cada momento e em cada experiência, evitando a projeção de sua figura, tal como aparece ao fim da vida” (ALVES, 2012, p.116).

A análise histórica da formação escolar do sujeito, de sua família e do meio social de sua origem, dos grupos de pertencimento e das adesões a causas temporárias ou duradouras auxiliam o historiador a evitar o erro da projeção de uma representação final, demarcando que o caminho não estava predefinido. Assim, “a atenção às escolhas, às decisões, às formas de inserção, aos embates que atravessam a vida de um intelectual deve dirigir a pesquisa que queira se pautar por essa noção” (ALVES, 2012, p. 116).

Qual seria o tom que regeu a trajetória intelectual de Souza Campos no âmbito do ensino superior? A investigação de suas formações acadêmicas, as viagens internacionais, o engajamento no debate público sobre as universidades e seus trabalhos nas construções de estruturas universitárias nos deu indícios para definirmos as especificidades de sua atividade intelectual. A identidade intelectual de Souza Campos está assentada em três pilares fundamentais: sua formação científica, que compôs o repertório simbólico e técnico profissional de sua atuação na arena pública, em diálogo com a cena política e institucional; as viagens internacionais, que serviram como referência de autoridade e legitimação de seus posicionamentos e a tomada para si de um sentido de missão, que correspondeu ao seu engajamento na causa do ensino superior como projeto de modernidade.

Quanto ao primeiro aspecto, o conceito de intelectual apresentado por Bobbio (1997, p.67-90) aponta uma caminho para pensar as relações dos intelectuais com o campo do poder. Estes podem atuar tanto como ideólogos ou expertos, isto é, especialistas, mesmo que ocorra a reunião das duas funções em uma mesma pessoa. Os ideólogos teriam como função fornecer 
princípios-guia para as ações, enquanto os expertos seriam responsáveis por fornecer os conhecimentos-meio para sua realização. Os intelectuais, independentemente de sua função, no entanto, não se identificam tout court com a classe política à qual estão vinculados, o que indica a possibilidade de constante negociação, aproximação e afastamento da órbita de poder. Assim, de acordo com essa relação com o poder, ora podem atuar como ideólogos, ora como expertos.

Tal definição elucida um dos principais aspectos da trajetória intelectual de Souza Campos no ensino superior. Souza Campos pode ser compreendido ora como experto, ora como ideólogo, sobre as questões que envolveram o debate pela causa da universidade, a construção do prédio da Faculdade de Medicina ou do plano do campus da Universidade do Brasil e da Universidade de São Paulo, pois tanto usou o conhecimento técnico adquirido em sua formação como engenheiro, médico e em suas missões estrangeiras, como defendeu publicamente concepções e princípios sobre a universidade, em consonância com as diretrizes das políticas públicas em educação dos governos federal e paulista.

O segundo elemento fundante da atividade intelectual de Souza Campos foram suas experiências de viagens. Nos anos 1920 e 1930, Souza Campos foi protagonista de diversas viagens entre países da Europa, América e Ásia. Este período de sua trajetória intelectual apresentou-se marcante para a atuação posterior como debatedor da questão do ensino superior, posto que durante seu trabalho no estrangeiro tomou contato com renomadas universidades e criou um repertório pessoal sobre as formações históricas e a organização dessas instituições, subsídios utilizados por ele como elementos de autoridade e legitimação de suas concepções nos embates sobre o ensino superior brasileiro.

Dessas viagens resultaram pronunciamentos em debates, publicações em periódicos, relatórios e o convite para atuar, no Brasil, na criação de espaços institucionais de ensino superior. Suas viagens, feitas a partir de motivações profissionais, formaram um repertório informativo e crítico sobre os princípios e aspectos constituintes das instituições de ensino superior ao redor do mundo, utilizado em debates sobre a universidade e trabalhos para as universidades. Conforme apontou Gondra (2010, p.13), os registros que resultam de viagens devem ser compreendidos pelo historiador da educação como técnicas de investigação e conhecimento, como registros de uma prática de observação, experimentação, comparação e produção de conhecimento sobre o outro. É a materialização de um exercício de poder, de 
autoridade que advém do ato de testemunhar. Esta é a diferença existente entre aquele que viajou e aquele que escuta o relato e se apropria do conhecimento veiculado.

Foram, portanto, as experiências estrangeiras de Souza Campos, utilizadas por ele como um diferencial no debate público, nos projetos da Faculdade de Medicina e nas universidades, que convertidas em valor de autoridade, alicerçaram seu prestígio público e reconhecimento entre os pares quanto à causa do ensino superior.

A questão do olhar sobre o estrangeiro e do testemunho sobre essa experiência leva-nos a problematização da noção de apropriação, sob as luzes dos estudos de Michel de Certeau (1996) e Roger Chartier (2002). Souza Campos, assim como demais intelectuais de seu tempo, foi ao estrangeiro em busca de compreender o outro para mudar sua realidade, especificamente, de conhecer e analisar modelos universitários para o projeto de ensino superior brasileiro. No entanto, essa busca pela outro não se deu de maneira ingênua e com a intenção de transplantar moldes, sem seleção e crítica. A incorporação de valores culturais da Europa e dos Estados Unidos, em especial, dão-se por meio de apropriações que passam tanto pelo crivo pessoal dos viajantes, quanto pelas condições sociais, históricas, políticas e institucionais às quais está condicionado (CARVALHO, 1998, p.30). No caso, compreendemos as apropriações de modelos universitários feitos por Souza Campos como parte de um contexto de circulação de modelos pedagógicos e culturais, nos quais os sujeitos têm papel preponderante em sua captação em escala internacional e na promoção em sua realidade sociocultural.

O que circula, na verdade, não são o pensamento ou as experiências originais, mas uma espécie de "vulgata", ela mesma sincrética, contaminada por referências "indígenas”. A questão não é, pois, a de procurar raízes ou influências diretas, mas, particularmente, a de especificar a forma original como as ideias são apropriadas na tentativa de resposta a condições particulares do contexto, resultando numa espécie de “mestiçagem” ou "hibridismo" pedagógico (CARVALHO; PINTASSILGO, 2011, p. 11).

As apropriações, isto é, os usos dos modelos e ou objetos culturais, podem ser compreendidos em uma chave interpretativa nomeada por Certeau (1996) como polemológica, entre táticas de apropriação e estratégias de imposição de modelos culturais.

Uma história dos usos que indivíduos, grupos ou sociedades fazem dos modelos que lhes são impostos ou dos objetos que lhes são distribuídos supõe -- já o dissemos -- um trabalho sobre a relação entre táticas de apropriação e estratégias de imposição. Isso porque uma história dos usos não pode ignorar as resistências que os objetos ou modelos culturais 
oferecem à sua utilização, ou os limites que a ela impõem, o que traz inúmeras dificuldades, algumas conceituais e outras relativas à informação sobre os modelos ou os objetos cujos o pesquisador pretende privilegiar em sua investigação (NUNES; CARVALHO, 2005, p. 53).

Ao reconstruir os ambientes e as práticas culturais em que Souza Campos esteve envolvido, percebemos que ora ele atua com propositor de estratégias, ou seja, como aquele que detém o poder de decisão e definição, ora atua taticamente, aproveitando as lacunas e as oportunidades das circunstâncias no campo do dominador, apropriando-se de modelos, objetos e conhecimentos para conseguir imprimir sua atividade intelectual no campo educacional. Além disso, o modelo polemológico nos permite perceber o constante jogo de forças envolvidas no processo de apropriação e projeção de modelos culturais, no caso, de modelos universitários para o Brasil moderno.

Levando em conta os embates que Souza Campos travou ao longo de duas décadas para a implantação e consolidação da universidade como local da pesquisa científica, observamos que seu discurso tomou o lugar de ação, foi a concretização de suas ideias como estratégia cultural. Conforme apontam Nunes e Carvalho (2005, p.55), a análise dos discursos como objetos de pesquisa dentro da linha encetadas por Michel de Certeau e Roger Chartier implicam procedimentos metodológicos que devem considerá-los como as próprias estratégias de persuasão ou de demonstração de seu veiculador.

Por fim, a trajetória intelectual de Souza Campos está intimamente ligada a um sentido de missão, traduzida na expressão “apostolado” pelo ensino superior. Este aspecto de sua identidade intelectual, contudo, não é uma característica singular, mas geracional. Ao investigar o percurso intelectual de Erasmo Pilotto, Vieira (2011) aponta ferramentas metodológicas e chaves interpretativas substanciais para a análise do intelectual brasileiro do final do século XIX até meados do XX. Uma das características essenciais para apontar o sujeito como intelectual é, além de seu pertencimento e reconhecimento neste estrato social, suas relações com o Estado e com os discursos de modernidade, a identificação com um sentimento de missão social dos cultos, como mote de sua atuação no campo político.

O termo missão, historicamente associado ao clérigo na Idade Média e, depois, ressignificado para explicar a posição social do professor na Modernidade, foi usado no discurso da intelectualidade brasileira para expressar o imperativo do dever e a decisão de engajamento político dos intelectuais. Na educação, o engajamento político representou uma característica comum dos intelectuais que se associaram ao campo, pois a 
educação foi e permanece sendo espaço de prática e de intervenção social (VIEIRA, 2011, p.36).

Mesmo partilhando das marcas simbólicas que lhe foram impressas durante as formações acadêmicas na engenharia e na medicina, sobretudo a partir de 1925, Souza Campos passou a atuar no espaço público tomando para si a causa do ensino superior, questão que se tornou uma missão e um caminho para a intervenção social por meio da causa educacional. Assim, progressivamente, Ernesto de Souza Campos passou a associar-se ao campo educacional, por meio de suas particularidades de formação profissional e científica, assim como pelo engajamento em projetos políticos institucionais.

Esta conversão à causa educacional pode ser explicada pela confluência de diferentes grupos de intelectuais ao discurso da modernidade, profundamente imbricado com a questão da educação.

No horizonte retórico dos intelectuais do último quartel do século XIX aos anos 60 do século XX, identificamos a presença marcante da ideia de modernidade, que foi representada como uma espécie de éden que se conquistaria a partir de investimentos em diferentes frentes, mas, de forma especial, a cultura e a educação representam áreas estratégicas nesse projeto. A análise do discurso da intelectualidade no Brasil, nas particularidades dos agentes que se destacam no campo educacional, bem como nas redes de sociabilidade intelectual criadas pelos jornais, revistas e instituições culturais confirmaram a tese, bastante difundida na área acadêmica, sobre a relação estreita entre os ideais de modernidade e a defesa de investimentos em cultura e em educação (VIEIRA, 2011, p.38-39).

Se a questão educacional pode ser entendida como um ponto de convergência entre os intelectuais, os meios para atingir o projeto de modernização implicou disputas que passam pelo conjunto das representações dos diferentes grupos que propalaram, a partir de seu papel social de salvação, propostas divergentes de encaminhar o Brasil. Nesta perspectiva e a partir da trajetória de formação e atuação intelectual de Souza Campos, destacamos os trabalhos de Bontempi Jr. (2015, 2016), Herschmann, Kropf e Nunes (1996), Mota (2005) e Cerasoli (1998), que analisam as relações entre as representações dos profissionais dos $\operatorname{campos}^{2}$ da

\footnotetext{
${ }^{2}$ Temos como referência teórica para o uso do termo campo a obra de Bourdieu (2004). Para o autor, a noção de campo é um instrumento para analisar o universo no qual estão inseridos os sujeitos e as instituições que produzem, reproduzem ou difundem arte, a literatura ou ciência, como um microcosmo social, dotado de leis próprias e relativamente autônomo em relação ao macrocosmo. O campo, marcadamente o científico, pode ser considerado um espaço de jogo de forças, onde lutas internas ocorrem entre os agentes para a conservação ou renovação desse campo, de acordo com o poder derivado da posição que nele ocupa. No entanto, faz-se necessário a ressalva que o uso de campo nesta tese é menos rigoroso do que em Bourdieu, ou seja, ele vale também para campos em formação e subcampos, sem a devida investigação e problematização da efetiva
} 
medicina, da engenharia, do direito e da educação com os discursos de modernização e modernidade que defenderam para o país.

As representações do mundo social assim construídas, embora aspirem à
universalidade de um diagnóstico fundado na razão, são sempre
determinadas pelos interesses de grupo que as forjam. Daí, para cada
caso, o necessário relacionamento dos discursos proferidos com a
posição de quem os utiliza.[...] As lutas de representação têm tanta
importância como as lutas econômicas para compreender os mecanismos
pelos quais um grupo impõe, ou tenta impor, a sua concepção do mundo
social, os valores que são os seus, e o seu domínio (CHARTIER, 2002,
p.17).

Junto à análise das diferentes estratégias de representações da missão social do médico, do engenheiro e do educador, somamos a investigação do papel social do arquiteto, com base nos trabalhos de Tafuri (1985) e Kopp (1990). Sendo assim, apresentamos no capítulo primeiro os conflitos e as místicas características das principais formações profissionais de ensino superior, configurando o quadro dos embates dos projetos de modernidade que compuseram o final do século XIX até meados de 1950. Fomos convidados a compreender a formação do campo científico nacional na virada do século $\mathrm{XX}$, as figuras do engenheiro, do médico, do arquiteto e do educador como agentes de modernização e civilização do Brasil considerado arcaico, e especialmente, compreender sua ideia de missão por meio da ciência. Por esta razão, problematizamos a trajetória de Souza Campos através de suas formação acadêmica na engenharia e na medicina, e as aderências e embates com outros campos, como o educacional e o arquitetônico, por conta de seu comprometimento com a causa das universidades.

No segundo capítulo, tratamos de apresentar a aproximação de Souza Campos com a filantropia científica da Fundação Rockefeller, sua viagem e estada nos Estados Unidos como bolsista da instituição e o contato com a realidade universitária norte-americana, o retorno ao Brasil e as disputas que travou para sua colocação no campo médico paulista. Também abordamos sua viagem à Europa, Estados Unidos e Canadá comissionado pela Rockefeller e pela Faculdade de Medicina, e o decorrente trabalho dessa missão na projeção e execução da obra da nova sede da faculdade. Para tratar desse período, nos amparamos especialmente nos trabalhos de Maria Gabriela Marinho (2013b) ${ }^{3}$, André Mota (2005), na obra comemorativa do

existência de suas condições estruturantes naquele momento histórico, tendo como objetivo facilitar a compreensão de um aspecto do traçado teórico metodológico da pesquisa.

${ }^{3}$ A dissertação de mestrado de Maria Gabriela Marinho foi defendida na Universidade de Campinas, em 1993. Ao longo do trabalho utilizaremos a versão reimpressa, publicada em 2013, na Coleção Medicina, Saúde e História. 
centenário da Faculdade de Medicina e em coletâneas coordenadas pelos autores a respeito da história da Faculdade de Medicina e do ensino médico paulista (MARINHO; MOTA, 2012, 2013, 2014). Ao final da década de 1920 e início de 1930, ancorado em seu prestígio com a construção do prédio da faculdade e com os conhecimentos adquiridos nas viagens, apresentamos como Souza Campos passou a atuar no debate do Rotary Club de São Paulo sobre a criação das universidades, em clara defesa de aspectos do modelo norte-americano, participando com iniciativas e discursos no debate público até a criação da Universidade de São Paulo, configurando assim a investidura de sua missão, o “apostolado” pela universidade.

Por fim, no capítulo terceiro analisamos as atuações mais significativas de sua missão, que foram a consolidação da Faculdade de Filosofia, Ciências e Letras da USP, a idealização do plano da cidade universitária da Universidade do Brasil e da cidade universitária da Universidade de São Paulo. Nessa perspectiva, apresentamos as obras de Souza Campos como ideólogo e experto sobre universidades e cidades universitárias, conhecedor e defensor do “espírito e do corpo da universidade”, protetor dos princípios fundantes da FFCL como "alma mater” da universidade e promotor de sua materialização no projeto da cidade universitária. Assim como no capítulo segundo, rastreamos as formas de apropriação de Souza Campos de aspectos do modelo norte-americano de universidade em seus trabalhos. Na FFCL da USP, como diretor, apresentamos e analisamos a batalha que travou com a Congregação da Escola Politécnica em favor da centralização das cadeiras de disciplinas fundamentais, na expectativa de promover a formação do “espírito universitário”. Em relação às cidades universitárias, Souza Campos teve atuação relevante na configuração dos primeiros projetos elaborados, na perspectiva de criar espaços que representassem espacialmente os princípios contidos nos planos das universidades, em consonância com elementos de modelos internacionais. No caso da universidade federal, disputou o poder de controle desses projetos com arquitetos modernos, em um embate entre o crescente prestígio do campo da arquitetura moderna brasileira e uma concepção de organização espacial pedagógica e de matriz estética diversa, ligada aos objetivos propalados nos projetos de criação das respectivas universidades. 


\section{FORMAÇÕES ACADÊMICAS E SUAS REPRESENTAÇÕES SOCIAIS NA TRANSFORMAÇÃO DO ESPAÇO URBANO: O SENTIDO DE MISSÃO PELA CIÊNCIA}

Ernesto de Souza Campos nasceu em 21 de setembro de 1882, em Campinas, e faleceu aos 88 anos, em 1970. Iniciou sua vida profissional ao formar-se engenheiro pela Escola Politécnica de São Paulo, em 1906 e, em 1908, esposou Celestina Brito de Souza Campos, com quem teve cinco filhos. Exerceu a profissão de engenheiro por alguns anos, porém imprimiu mudança definitiva à carreira ao formar-se médico, em 1918, na primeira turma da Faculdade de Medicina e Cirurgia de São Paulo. Doutor na área médica em 1919, Souza Campos tornou-se catedrático desta instituição em 1925 e neste cargo permaneceu até ser jubilado por idade em 1952, com 37 anos de atividade acadêmica, ganhando ao final da carreira as honrarias de professor emérito da Universidade de São Paulo, Honoris Causa das universidades do Recife, do Paraná e da Bahia e Scientia ei Honoris Causa da Pontifícia Universidade Católica de São Paulo (CAMPOS, 1956).

O relacionamento de Ernesto de Souza Campos com o ensino superior perpassou de forma intensa sua trajetória intelectual. Ele foi produto e produtor de suas instituições. Como homem da elite republicana paulista do final do século XIX, Souza Campos iniciou seus estudos superiores em uma estrutura herdeira da tradição de institutos isolados, característicos desde o período imperial, porém ressignificado pelos valores e ideais republicanos. Entre os símbolos que marcaram o nascente republicanismo nacional, e mais especialmente o paulista, estava a crença na ciência como ferramenta para alcançar os desígnios políticos. Diversas perspectivas foram postas como caminhos para atingir esse fim, não somente no período derradeiro daquele século como no início do seguinte, temporalidade na qual se inscreve o percurso acadêmico e intelectual de Souza Campos.

Conforme afirmou Mendonça (2000), tanto no período imperial quanto no momento da República Velha, o ensino superior brasileiro caracterizou-se por seu pragmatismo, que encontrou espaço na criação de escolas e faculdades, e não no modelo universitário, este ligado à pesquisa científica. O modelo universitário somente viria a existir na década de 1920, recebendo profusas críticas, que o reformulou e consolidou a partir da década de 1930.

Entre as áreas de saber profissional que foram eleitas como essenciais para a formação da elite nacional estavam a engenharia, a medicina, o direito e a educação. Esses campos 
científicos, formados historicamente de acordo com suas especificidades, têm em comum o objetivo de corresponder a um problema comum: tirar o Brasil do "atraso" em relação às sociedades civilizadas e colocá-lo nos trilhos da modernidade. Cada área concedeu respostas autônomas, privilegiando seu papel na transformação da sociedade e do país, rumo ao progresso. Ao analisar os campos da engenharia, da medicina e da educação no Rio de Janeiro da virada do século e suas representações como portadores dos ideais de progresso e civilização, Herschmann, Kropf e Nunes (1996, p.7) explicam:

Apresentando-se como categorias diferenciadas por uma formação técnico-científica, médicos, engenheiros e educadores engajaram-se ativamente no que acreditavam ser a construção de um novo saber sobre a nação, um saber que, respaldado nas supostas objetividade e eficácia da ciência, era tido como diretamente responsável por encaminhar a sociedade nos rumos de uma "evolução regeneradora". Guardadas as especificidades e diferenças própria a cada campo, esses sujeitos, no processo mesmo de busca pela afirmação e legitimação de sua identidade enquanto grupo, construíram para si e reivindicaram perante a sociedade o papel de articuladores de uma nova ordem, que pretendia selar o presente enquanto marco divisório entre um passado condenado como sinônimo de atraso e inércia e um futuro enaltecido como símbolo de promissora potencialidades para a "redenção nacional".

Por conta do trânsito do próprio personagem por essas carreiras, percorremos a história e a memória de Souza Campos nas interações com os campos da engenharia, da medicina, da educação e da arquitetura. As duas primeiras áreas foram os campos que marcaram sua identidade intelectual. Já o campo educacional, tanto quanto o arquitetônico, surgiu no itinerário intelectual de Souza Campos em diálogo e em confrontos com os campos de sua formação acadêmica, especialmente a partir da década de 1910.

Sua história familiar tem como espaço geográfico privilegiado os estados de São Paulo e Rio de Janeiro, onde estavam as instituições de sua formação acadêmica e onde se desenrolaram os principais acontecimentos de sua atividade profissional. A família Souza Campos, como componente da elite paulista, participou ativamente dos movimentos políticos do início do regime republicano. Filho de Pedro José de Souza Pimentel e Escolástica Ferraz de Campos, fazendeiros de café da cidade de Campinas, importante centro econômico e político republicano, Antônio de Souza Campos, pai de Ernesto, mudou-se com a família para o Rio de Janeiro em 1867, onde matriculou-se na Faculdade de Medicina. Ainda estudante foi signatário do Manifesto Republicano, publicado em 3 de dezembro de 1870. Após formar-se, em 1873, casou-se com Cândida Rosa Velho Bittencourt. No ano de 1879, fundou em propriedade de sua 
família um “clube republicano” do qual foi presidente e José do Patrocínio o primeiro secretário. Engajou-se no movimento republicano no Rio de Janeiro e em São Paulo. Na capital do Império, foi companheiro de luta de Saldanha Marinho, João Clapp, Lopes Trovão, Pedro Ferreira Viana, Aristides Lobo, José do Patrocínio e Quintino Bocaiúva. Na capital paulista, foi companheiro de causa dos republicanos Rangel Pestana, Campos Sales, que era seu primo por parte da descendência materna, Francisco Glicério, Bernardino de Campos, Cerqueira César, Júlio de Mesquita e Pereira Barreto. Com a proclamação da República, Antonio de Souza Campos participou do Congresso Estadual como senador. Apoiou o Estado de S. Paulo em defesa do governo de Américo Brasiliense e manteve-se ao seu lado em sua queda ${ }^{4}$. Segundo relato de Ernesto de Souza Campos, seu pai era amigo íntimo de Américo Brasiliense. Juntos, os correligionários “debatiam assuntos do passado e problemas da época, antevendo o futuro” em encontros na chácara da família Velho Bittencourt, ancestrais maternos de Ernesto, localizada no Rio de Janeiro (CAMPOS, 1954, p.345-346).

De acordo com Alonso (2002), a geração de 1870, composta por intelectuais contestadores do Império caracterizou-se por utilizar um repertório de ideias da política-científica europeia e norte-americana apropriadas para apontar reformas do sistema vigente. Entre os diversos grupos que compuseram essa geração, que diferenciavam-se quanto ao projeto político e à forma de interpretar os problemas nacionais, destacam-se os liberais republicanos e os federalistas científicos de São Paulo, grupos com os quais Antônio de Souza Campos manteve relações políticas.

Os liberais republicanos, núcleo que fundou o primeiro Clube Republicano no Rio de Janeiro e publicou o Manifesto Republicano tinham como base o "liberalismo democrático" de inspiração republicana francesa e interpretavam a crise do Império como sinônimo de

\footnotetext{
${ }^{4}$ Folha da Manhã. As inspiradoras dos paulistas de ontem e de hoje. A geração atual da família Sousa Campos. São Paulo, 3 de maio de 1953, s/p. [Fundo Ernesto de Souza Campos]. Deodoro caiu como resultado de uma sublevação bem sucedida, articulada no Rio Grande do Sul, apoiada pelos republicanos "históricos" e grupos militares no Rio, concluída com uma revolta da Marinha, que eclodiu a 23 de novembro. A 15 de dezembro de 1891, Brasiliense foi deposto por antigos companheiros do PRP, renunciando em favor de seu sucessor legal, José Alves de Cerqueira César, vice-governador e cunhado de Campos Sales. "Não há dúvida de que, entre as cisões provocadas pela dinâmica da política nacional, a mais importante foi a sequência do triunfo e derrota de Américo Brasiliense, em 1891-92, que afastou a maioria dos ex-monarquistas do poder, de modo permanente" (LOVE, 1982, p. 162). A partir da contextualização apresentada por Love sobre o fato, podemos deduzir que Antonio de Souza Campos sofreu o "expurgo" feito pelos republicanos "históricos" durante a primeira crise interna do Partido Republicano Paulista após a constituinte, devido ao apoio dado a Américo Brasiliense. De acordo com Souza Campos (1954, p.346), seu pai manteve-se ao lado de Brasiliense, e após sua queda o senador abandonou a política e retirou-se para o interior de Minas Gerais, local onde deixou de morar somente para retornar a São Paulo no governo do presidente da República Prudente de Morais.
} 
decadência e inadequação do centralismo monárquico, no entanto, sem afrontá-lo integralmente. A forma de governo deveria ser a república federativa, à luz dos Estados Unidos, mantendo o sistema escravocrata e incentivando a imigração de mão-de-obra livre. A linguagem tinha um teor organicista, que compreendia a sociedade como um corpo social doente e degenerado, que necessitava do diagnóstico correto para a busca da cura pelas reformas propostas (ALONSO, 2002, p.-179- 185).

No estado de São Paulo, os federalistas científicos, organizados no Partido Republicano a partir da Convenção de Itu, ocorrida em 1873, guardavam algumas aproximações diagnósticas dos problemas nacionais com os liberais republicanos. A monarquia seria um regime político artificial, não condizente com a nação brasileira. Criticavam contundentemente a elite imperial pela inadequação das instituições políticas vigentes, consideradas decadentes. Quanto a economia, os paulistas eram penalizados pelo sistema centralizado de contribuição, sustentando com sua produção ascendente os estados em crise. Além disso, a legislação imperial não correspondia aos anseios da expansão cafeeira. Politicamente, os paulistas sofriam com a falta de representatividade, em descompasso com sua proeminência econômica no cenário do momento. Dessa forma, o remédio para os males da economia e da política seria o regime republicano federativo. A escravidão era vista como uma mazela, mas deveria ser combatida com “bom senso” e “dentro da ordem”, e substituída pela mão-de-obra imigrante (ALONSO, 2002, p.230-237).

Os dois grupos, ao defenderem a república federalista propunham uma política na qual cada estado tinha autonomia para direcionar sua legislação e, consequentemente, sua administração econômica e política social. No caso paulista, essa era uma questão nodal, pois a elite cafeeira buscava por meio do Partido Republicano organizar as políticas estatais de acordo com seus interesses. Sendo assim, com o fim do Império e a instauração da República, foi redigida a Constituição Estadual de 1890, que estabeleceu o Congresso do Estado de São Paulo, composto de uma Câmara de Deputados com mandato de três anos e uma Câmara de Senadores, com mandato de seis (apud CERASOLI, 1998, p. 42). Os legisladores em exercício em 1891 foram responsáveis pelos primeiros projetos de criação das instituições republicanas, como os casos dos institutos de ensino superior e dos órgãos sanitários. Dentre eles estava Antônio de Souza Campos, senador que representava os interesses da classe produtora “ilustrada”, ao lado dos senadores Luiz Pereira Barreto, Paula Machado, Paula Ramos, José Vieira de Carvalho, Arthur Breves e Júlio de Mesquita. Nessa ocasião, Pereira Barreto, Paula 
Machado, Paula Ramos, Souza Campos e Vieira de Carvalho deram andamento ao projeto número 13 de 1891, que propunha a criação da Escola Superior de Agricultura, ao mesmo tempo que a Câmara dos Deputados encaminhava os projetos da Academia de Medicina e Cirurgia de São Paulo e de outra Escola Superior de Agricultura e Veterinária (CERASOLI, 1998, p.43).

Os três institutos superiores propostos correspondiam diretamente aos anseios da elite cafeeira paulista, pois seriam a base para a formação dos lavradores e da manutenção sanitária da mão-de-obra para as áreas produtoras. No entanto, entre as disputas internas dos grupos no poder, a academia de medicina acabou esbarrando nas discussões acerca das "condições para o funcionamento da escola, como a necessidade de um hospital equipado, de amplos recursos e da contratação de professores”, e outra escola, a de engenharia, acabaria tomando maior dimensão e vingando como resultado do debate de diferentes propostas (CERASOLI, 1998, p.28-29).

O projeto do Senado de criação da Escola Superior de Agricultura e de dez estações agronômicas a ela subordinadas recebeu modificações, incluindo uma emenda pela Câmara dos Deputados que lhe acrescentou uma escola de Engenharia. O projeto acabou tomando força de lei em maio de 1892, e ambos institutos tinham em sua estrutura curricular uma tendência ao ensino prático, mais do que teórico. Entretanto, o engenheiro e deputado Antônio Francisco de Paula Souza apresentou à Câmara, em abril de 1892, projeto para a criação de um instituto politécnico diverso ao do Senado, que gerou intensos debates e "uma tomada de posição mais clara do Congresso paulista em relação à instrução técnica, ao ensino público e às funções governamentais referentes à instrução” (CERASOLI, 1998, p.47- 49). Por fim, foi implantada a Escola Politécnica de São Paulo aos moldes de Paula Souza, resultado da união dos projetos do Senado e da Câmara pelo executivo, em agosto de 1893.

\subsection{AS MARCAS DO “ESPÍRITO POLITÉCNICO”}

Desde a segunda metade do século XIX, o eixo Rio de Janeiro - São Paulo constituía o centro econômico do Império, por conta da produção cafeeira que se expandia no sentido do oeste paulista. A economia cafeeira proporcionou o acúmulo de capital que foi aplicado no setor industrial, desenvolvendo os dois setores de forma complementar e favorecendo assim o processo de urbanização dessa área. Os capitais excedentes da produção de café eram investidos 
em ferrovias, bancos e indústrias, em torno das principais cidades dos estados do Rio de Janeiro, São Paulo e Minas Gerais (TELAROLLI Jr., 1996, p.24-25).

Esse cenário de crescimento urbano, ligado à dinamização dos setores agrário, do comércio e da indústria, foi o ambiente de ação dos engenheiros como reformadores do espaço físico da nação. Antes de ingressar na Medicina, Souza Campos havia se formado engenheiro agrônomo $^{5}$ pela Escola Politécnica, em 1906. De acordo com as informações de sua pasta de aluno, matriculou-se em 28 de agosto de 1900 para o curso preliminar e, a partir do ano letivo de 1901-1902, optou pelo curso de engenheiros agrônomos, seguindo a lógica de formação desejada por seu pai como senador. De acordo com o regulamento em vigor no período, a primeira divisão do curso era composta pela formação de engenheiros civis, industriais e arquitetos, com carga horária de seis anos de estudos, e pela formação de engenheiros agrônomos, com o período de cinco anos de estudos (ESCOLA, 1906, s./p.).

Em resumo, conforme a versão regulamentar de 1897, o curso de engenheiros agrônomos era composto no primeiro ano por estudos de física, química e botânica, mais aulas de laboratório, com Desenho Topográfico e de Construções, seguido de cadeiras de Mineralogia e Geologia, Agricultura e Zoologia e aula de Prática de Cultura no segundo ano. No terceiro, acrescentava-se diferencialmente a cadeira de Mecânica Elementar e Zootecnia e no quarto ano, as cadeiras de Veterinária e de Técnica e Economia Rural (ESCOLA POLITÉCNICA, [1935?], p.7).

Na sessão solene de formatura, Souza Campos recebeu o prêmio Dr. Luiz Pereira Barreto $^{6}$, destinado ao melhor aluno da turma em sua especialidade. Além da honraria, o prêmio lhe garantiu colocação como funcionário do Estado por um ano, cargo que exerceu por pouco tempo pois preferiu abrir um escritório na capital (CAMPOS, 1923, p.4). Ganhando o prêmio, Souza Campos iniciou a carreira na engenharia em posição de destaque, além de um posto profissional junto ao governo estadual. Sua formação de engenheiro agrônomo lhe proporcionou conhecimentos teóricos e práticos que possivelmente aproveitou adiante, durante

\footnotetext{
${ }^{5}$ A especialidade da formação de Souza Campos na Escola Politécnica era uma incógnita, pois em seu arquivo pessoal não consta o diploma e em seus memoriais não há menção a sessão cursada. Sendo assim, foi necessária a busca por documentação externa, encontrada no Arquivo Geral da Escola Politécnica e nos Anuários da mesma instituição. Tanto em sua pasta de aluno (número 689) quanto no anuário de 1907, que publicou as solenidades da formatura da turma de 1906, ficam confirmadas sua formação como engenheiro agrônomo.

${ }^{6}$ A personalidade que dava nome ao prêmio, Luiz Pereira Barreto, era médico e político de grande prestígio. Foi membro da comissão executiva do Partido Republicano Paulista e elegeu-se senador, ao lado de Antônio de Souza Campos (MARINHO, 2014, p.16-17).
} 
o curso de medicina, mas proporcionou, além disso, sua inserção em um grupo profissional e social de prestígio e poder ${ }^{7}$. Mais que isso, a formação na escola de engenharia teria lhe conferido uma formação moral e ideológica, baseada nos ideais de progresso, modernidade e civilização, os quais Souza Campos levaria consigo em atuação profissional e acadêmica.

Quanto à missão que a Escola Politécnica de São Paulo arrogava para si, a instituição tinha como objetivo formar homens de saberes superiores preparados para a vida prática, tendo como pilar a crença no saber científico e técnico a serviço da pátria, em contraposição ao saber “literário”, no momento identificado com a formação de bacharel em direito.

O olhar do engenheiro sobre a realidade constrói-se [...] como um olhar pragmático, que tem como objetivo determinante agir sobre ela e transformá-la. É o olhar da obra, da construção e da construtibilidade; e a ótica através da qual ele se julga capacitado a estabelecer os marcos de sua ação é a ciência (KROPF, 1996, p.104).

Segundo Bontempi Jr. (2015, p.231), "nos discursos de formatura da Poli figuram as imagens de uma escola e de um corpo profissional voltados ao progresso pelo domínio da ciência positiva e da técnica, a defesa do industrialismo e a ênfase na formação do caráter do alunado”. Nessa perspectiva, Cerasoli (1998, p.23) destaca que

envolvidos pelo otimismo científico que pairava sobre as "elites ilustradas”, os engenheiros não poderiam cruzar esses caminhos em direção à modernidade, ao progresso e à civilização, sem aderir ao idealismo que se constituía como uma das tônicas do cientificismo do século XIX. Frequentemente a superação desse descompasso entre ser e dever-ser adquiria proporções de missão, de chamado, como se partissem numa "Cruzada civilizatória". Nas palavras do formando [Alexandre Albuquerque] de 1905: "hoje saímos armados cavaleiros da Grande Cruzada”.

\footnotetext{
${ }^{7}$ No ano letivo de 1905-1906, Souza Campos ocupou o cargo de secretário da terceira diretoria do Grêmio Politécnico, atuando também na ocasião como presidente interino. "Colaborou na Revista Polytechnica e exerceu numerosas comissões como representante dos alunos de engenharia”, época em que Paula Souza e Ramos de Azevedo eram diretor e vice, respectivamente. Além de sua atuação estudantil no Grêmio Politécnico, que teria lhe conferido experiência no trato político com os professores, Souza Campos participou de associações profissionais da categoria, mantendo após sua formação os laços profissionais e de ideais com a comunidade dos engenheiros. No Instituto de Engenharia de São Paulo, órgão criado em 1916 como centro de organização profissional e política da classe, foi membro fundador e na Sociedade dos Arquitetos e Engenheiros de São Paulo, criada em 1912, exerceu o cargo de secretário e tesoureiro (CAMPOS, 1923, p.5). O Instituto de Engenharia teria surgido como reação dos engenheiros paulistas frente à contratação de um arquiteto francês para as obras no Estado e pela necessidade de organização da categoria. A associação, criada sob os auspícios de Antônio Francisco de Paula Souza e Rodolpho de São Thiago e apoiada por docentes e alunos da Escola Politécnica, foi fundada em sua sede "com a proposição de defender os direitos da categoria e dos interesses da classe, a regulamentação e a cooperação profissional e o posicionamento frente a questões nacionais", que viria posteriormente dar origem ao Conselho Federal de Engenharia e Arquitetura, em 1933, e promover a prestação de serviços de estudos técnicos e publicações periódicas da área (INSTITUTO DE ENGENHARIA, 2016).
} 
A par do saber técnico, o engenheiro constituía-se por qualidades morais superiores como honra, mérito, patriotismo, responsabilidade e altruísmo. Por essa razão, as metáforas religiosas foram incorporadas ao seu discurso de autorrepresentação, pois pretendiam associar seu papel ao de missionário, levita da ciência que possui a tenacidade moral para lutar em nome dos interesses gerais da sociedade. A cidade, lugar privilegiado da ação de salvação desses engenheiros era considerada como um laboratório ou um canteiro, lugar de exercício das potencialidades de sua ação criadora, de intervenção, controle e modificação do espaço urbano e social (KROPF, 1996).

Mesmo diplomado como engenheiro agrônomo, Souza Campos atuou por uma década em trabalhos voltados para a área da engenharia civil. Conforme Ficher (2005, p.26), embora existissem as distinções curriculares na primeira divisão do curso de engenheiro, na prática muitos graduados de um curso trabalhavam nas atribuições do outro até o advento das legislações do controle das profissões, o que pode explicar a trajetória de Souza Campos, se analisada conjuntamente com suas relações sociais, influência familiar e prestígio profissional ${ }^{8}$.

Egresso da Escola Politécnica e imbuído pela “espírito civilizatório” de sua profissão, Ernesto de Souza Campos passou a atuar com seus antigos docentes ${ }^{9}$ em obras públicas e pela iniciativa privada, construindo sistemas de saneamento, prédios médicos, escolares e edificações particulares (CAMPOS, 1923, p.4). Entre os projetos e obras que esteve envolvido estão:

- projeto de abastecimento de água e esgotos da cidade de Santa Cruz do Rio Pardo, em colaboração com Antônio de Cerqueira César;

\footnotetext{
${ }^{8}$ De acordo com Bontempi Jr. (2015, p.235), existiu até a década de 1930, momento de regulamentação da profissão do engenheiro, uma forte preferência entre os estudantes de cursarem engenharia civil e arquitetura, pois eram especialidades relacionadas à confecção de projetos e à construção de edificações, em expansão no momento, áreas que correspondiam a mais oportunidades de trabalho e o prestígio social.

${ }^{9}$ Antônio de Cerqueira César e Rodolpho São Thiago eram professores da Escola Politécnica e prestavam serviços para o governo do estado em obras de saneamento. Antônio de Cerqueira César era filho do jurista e político do Partido Republicano Paulista José Alves de Cerqueira César, correligionário de Antônio de Souza Campos. Seu pai foi presidente do Estado de São Paulo entre 1891 e 1892, após a queda de Américo Brasiliense, e presidente do senado de São Paulo entre os anos de 1898 e 1901. Antônio de Cerqueira César iniciou sua formação pela Escola de Minas da Universidade de Liége, mas transferiu-se para a Escola Politécnica de São Paulo, onde formou-se em 1899 e tornou-se professor em 1901. Casou com umas das irmãs de Ernesto, Elisa de Souza Campos, em 1906 (TAUNAY, 1915). Rodolpho de São Thiago foi engenheiro civil formado pela Escola Politécnica do Rio de Janeiro. Em São Paulo, trabalhou no serviço de águas de Itapetininga antes de tornar-se professor da escola de engenharia paulista, onde exerceu o cargo de secretário até a gestão de Ramos de Azevedo e, em seguida ao falecimento deste, o cargo de diretor (GRÊMIO POLYTECHNICO, 1933, p.217-218). Participou da Comissão de Saneamento do Interior do Estado de São Paulo e da capital, realizando trabalhos relativos aos serviços de água e esgoto. Manteve laços profissionais e de estreita amizade com Francisco de Paula Souza e Francisco Ramos de Azevedo (ESCOLA POLITÉCNICA, 2016).
} 
- projeto de abastecimento de água de Taquaritinga, em colaboração com Rodolpho de São Thiago;

- projeto e construção do Dispensário Modelo Clemente Ferreira, em colaboração com Antônio de Cerqueira César;

- construção do Grupo Escolar de São Joaquim, em São Paulo;

- construção da Escola Modelo e Cadeia de Itapetininga;

- construção do Grupo Escolar de Santana, em São Paulo;

- diversas construções particulares, trabalhos de topografia, irrigação e drenagem.

A questão da higienização por meio da construção de estruturas físicas de saneamento como forma de ordenamento social não era alheia aos politécnicos, que se consideravam, assim como os médicos, guerreiros na luta contra os estigmas da doente sociedade paulista. No discurso proferido pela ocasião de formatura da turma de 1905, Alexandre Albuquerque ${ }^{10}$, orador dos graduandos, afirmava:

somos o higienista protegendo não um homem mas populações inteiras contra os desvarios da Morte. Em todos os recantos se manifesta a constante preocupação da engenharia moderna no intuito de prolongar a existência humana (ESCOLA POLYTECHNICA, 1906, p.22).

Em São Paulo e no Rio de Janeiro, a vinda massiva de imigrantes para o trabalho na lavoura e na cidade em curto espaço de tempo, a facilidade de locomoção devido ao sistema ferroviário e os processos de migração campo-cidade geraram consequências epidemiológicas e sanitárias para os estados, pois doenças como a febre amarela, varíola e febre tifoide se alastraram nas principais regiões produtoras de café, na cidade portuária de Santos e na capital paulista. À época, a assistência médica era precária e dependia de recursos individuais privados (TELAROLLI Jr., 1996, p.27-30; p.38).

As questões da insalubridade e das epidemias tornaram-se um problema central para médicos e engenheiros, que assumiram a posição de traçar diretrizes para a transformação da cidade arcaica para a cidade moderna, civilizada, racionalizada e higiênica. Nessa perspectiva, a

\footnotetext{
${ }^{10}$ Alexandre Albuquerque foi aluno da Escola de Engenharia do Rio de Janeiro, transferido em 1903 para Escola Politécnica de São Paulo, onde formou-se como engenheiro civil e foi o primeiro presidente do Grêmio Politécnico. Entre 1907 e 1909 trabalhou no escritório de engenharia e arquitetura de Ramos de Azevedo, colaborando no desenvolvimento de projetos para a remodelação da cidade de São Paulo. Atuando na área da arquitetura, lecionou Composição Geral e História da Arquitetura e Estética e História das Construções Civis e Higiene das Habitações, na Escola Politécnica, sendo nomeado seu diretor em 1937 e permanecendo nesse cargo por um ano. Na política, foi vereador pelo Partido Republicano Paulista por duas gestões, entre 1926 e 1930 e 1934 e 1937 (ESCOLA POLITÉCNICA, 2017a).
} 
cidade moderna toma o papel de representação de uma sociedade sadia, vista como corpo são. Operando a partir do princípio da circulação e do movimento emprestados das teorias higienistas, os engenheiros remodelaram e normatizaram o espaço urbano, inspirados no trabalho de Haussmann na capital francesa (KROPF, 1996). Mesmo trabalhando ao lado dos médicos, o politécnico assume para si o controle desse processo de modernização, pois

o crescente agravamento das condições sanitárias provocado pelos periódicos surtos epidêmicos faz do saneamento uma questão na ordem do dia, imprimindo às discussões sobre a cidade um caráter de urgência quanto à concretização de soluções. É nesse contexto que se estabelece a projeção especial dos engenheiros: se por um lado o debate estava fundamentalmente embasado nos conhecimentos médicos propostos pelas teorias higienistas, a engenharia assume uma importância preponderante na medida em que se reconhece como sendo de sua alçada a competência e a responsabilidade pela materialização efetiva das obras saneadoras (KROPF, 1996, p.98).

Além das obras de saneamento básico, um importante marco do envolvimento de Souza Campos com projetos de regeneração nacional por meio da higienização da sociedade teria sido sua participação no projeto e construção do Dispensário Modelo Clemente Ferreira, ao lado de seu cunhado Cerqueira César. Essa experiência pode ser considerada representativa das relações sociais e políticas que Souza Campos mantinha com parte da elite paulista ligada ao movimento sanitarista. O Dispensário Modelo Clemente Ferreira, inaugurado em 1913, foi considerado como símbolo de sucesso da luta da Liga Paulista Contra a Tuberculose, organização filantrópica fundada em 1900 e liderada pelo médico Clemente Ferreira, que contava com o apoio de parte da classe médica paulista e da sociedade civil. A despeito de tentar aproximações com a política sanitarista oficial por meio do Serviço Sanitário, o movimento da Liga sofreu forte oposição por parte do órgão governamental e do grupo que considerava essas ações errôneas e ineficazes do ponto de vista médico e social, que pode ser representado pelo posicionamento contrário de Arnaldo Vieira de Carvalho e Emílio Ribas. Esta oposição simbolizava a transição entre um modelo de ação focada na campanha de erradicação de doenças para um voltado à educação médica e ações preventivas, como ficará evidente no processo de implantação da Faculdade de Medicina e Cirurgia de São Paulo (MOTA, 2005).

A despeito das resistências à construção do dispensário, ao ser apresentado à sociedade paulista, 0

edifício foi descrito pela imprensa como um grande passo nessa direção [da modernização], aproximando-se, por suas inovações tecnológicas e 
pela concepção dos espaços, do pensamento científico e moderno dos países europeus e norte-americanos. A complexidade de suas divisões, indicadas com precisão em cada andar, sancionava, em sua arquitetura, os novos tempos da higiene moderna (MOTA, 2005, p. 154, itálicos nossos).

A exaltação da opinião pública não era fortuita e correspondia aos anseios políticos e sociais de um grupo das classes dirigentes, que enxerga na construção do dispensário mais uma realização paulista no caminho da regeneração nacional, rumo à modernidade. Como forma de demarcar sua legitimidade, a propaganda do dispensário alegava sua estreita conexão com os mais modernos saberes europeus e norte-americanos nas áreas da arquitetura e da higiene, unindo ao saber médico à precisão métrica da técnica do engenheiro.

Os engenheiros politécnicos paulistas compartilhavam de um repertório político ideológico amplo, que caracterizou as gerações da elite produtora da República Velha. Alinhados à ideia do progresso derivado do saber científico, os países europeus e os norte-americanos eram os paradigmas a serem seguidos. Em especial, os Estados Unidos, país do mesmo continente que havia se libertado do sistema colonial e construído seu governo liberal democrático a base da industrialização, era um forte exemplo nos discursos politécnicos.

Apesar do modelo curricular da Escola Politécnica ser devedor das instituições congêneres na França e na Alemanha, Paula Souza, mentor do projeto, não deixava de transparecer sua admiração pelo “espírito industrial e comercial” dos norte-americanos (BONTEMPI Jr., 2015, p.232). Essa imagem de referência dos Estados Unidos aparece em outros discursos, como o do professor Francisco Ferreira Ramos, que relatou, em solenidade comemorativa da casa, detalhes de sua viagem pelas linhas férreas norte-americanas, solução que deveria ser incorporada ao Brasil (ESCOLA POLYTECHNICA, 1907, p.284-295); e do paraninfo da turma de Souza Campos, professor Brant de Carvalho, que afirmava ser os Estados Unidos o exemplo maior dos avanços na área da engenharia agronômica (ESCOLA POLYTECHNICA, 1907, p.81).

Além das obras de saneamento e do dispensário, destaca-se a atuação de Souza Campos na construção de grupos escolares. O complexo escolar de Itapetininga, elaborado por Ramos de Azevedo, constituiu um dos mais representativos exemplares do período da Primeira República por abrigar uma escola normal e dois grupos escolares, sediado em cidade escolhida por influência dos políticos republicanos Fernando Prestes de Albuquerque e Peixoto Gomide (SILVA, 2007). Cruzando as informações historiográficas com as existentes no arquivo pessoal 
de Souza Campos, depreendemos que a obra por ele executada foi o último prédio construído, localizado ao lado esquerdo da escola normal, que hoje abriga a Escola Estadual Cel. Fernando Prestes. Em continuidade aos trabalhos prestados para o governo do Estado, Souza Campos e Antônio de Cerqueira César apresentaram, em março de 1911, proposta para a execução do edifício. Nas anotações feitas por Souza Campos à margem das fotografias das obras, Souza Campos e Cerqueira César teriam construído o grupo escolar alguns anos depois, quando já estava no curso de medicina, e a mesma informação aparece registrada sobre a construção da cadeia e do grupo escolar de Santana.

Na Primeira República, os grupos escolares foram, assim como os institutos superiores de educação e a Escola Normal Caetano de Campos, compreendidos como símbolos da razão, da ordem e do progresso, instrumentos para modernizar, civilizar e moralizar a sociedade. "No projeto liberal dos republicanos paulistas, a educação tornou-se uma estratégia de luta, um campo de ação política, um instrumento de interpretação da sociedade brasileira e o enunciado de um projeto social” (SOUZA, 1998, p.26). Como projeto primordial das primeiras décadas da república, as escolas primárias foram criadas para serem o lugar de formação dos cidadãos republicanos, verdadeiros “templos de civilização”, nas palavras da autora. Para concretizar o projeto político de instrução do povo era necessário criar espaços específicos, edifícios apropriados para as práticas escolares e moralização das mentes e dos corpos. Sendo assim

essa modalidade de escola primária implicou uma nova concepção arquitetônica. Pela primeira vez, surge a escola como lugar, a exigência do edifício-escola como um espaço imprescindível para o seu funcionamento, dotada de uma identidade. A especialização dos espaços ocorreu de acordo com as finalidades do ensino, com as necessidades da completa separação dos sexos e com as exigências da pedagogia moderna: classes, bibliotecas, museus, laboratórios, oficinas, ginásios, pátios para recreio, auditórios (SOUZA, 1998, p.16).

Este fenômeno de estruturação de espaços escolares de acordo com valores pedagógicos e higiênicos igualmente se apresentou no cenário fluminense. Em meio a ainda existente precariedade da vida urbana, os educadores buscaram projetar "um organismo arquitetônico determinado pela natureza da escola”, para exercer sobre alunos e professores uma ação pedagógica (higiênica) que se irradiasse sobre a sociedade. Assim como no caso do aparelho sanitário, as escolas foram idealizadas a partir de dados técnicos, em comparação com congêneres internacionais, tornando-se uma metáfora de ordem da cidade ideal modernizada (NUNES, 1996, p. 166-168). 
O binômio saúde e educação se complementava. Em ambos os casos, a construção de prédios específicos, fundamentados nos valores e práticas civilizadas e modernas, de bases científicas, foram a forma de representação e materialização de um discurso de regeneração nacional, que assumia contornos pedagógicos e sanitaristas. Neste contexto, engenheiros, médicos e educadores trilharam a mesma “cruzada” contra o atraso, projetaram e criaram “templos” irradiadores da salvação da população, lugares de “formação do espírito” e da “mente e corpos sadios" -- a escola e os centros de pesquisa, profilaxia e tratamento médico. Ernesto de Souza Campos, na qualidade de engenheiro durante a década de 1910, atuou na construção de “templos de civilizar” e, junto a sua classe profissional, participou de projetos que visavam a reconstrução da nação mediante projetos modernizadores. Como pontuou Cerasoli (1998, p.26) sobre a atuação dos engenheiros, "seu envolvimento profundo com os projetos de construção nacional e com as concepções interpretativas da situação brasileira no período são marcas de sua conexão com a cultura e as ideias naquele momento”.

Por meio de trabalhos técnicos e imbuído dos valores morais adquiridos na área da engenharia, Souza Campos esteve envolvido em construções diretamente ligadas ao movimento educacional e sanitarista no estado paulista, promovidos tanto por órgãos públicos quanto pela iniciativa privada no início do século XX. Sua atuação no campo educacional e no médico, por meio do uso dos conhecimentos, técnicas e valores adquiridos no curso de engenharia prolongou-se por sua carreira como docente da Faculdade de Medicina, em São Paulo, no Rio de Janeiro e em outros estados do país, chegando a ocupar, em 1946, o cargo de Ministro da Educação e Saúde Pública no governo Dutra. Dada sua aproximação com o movimento sanitarista, no mesmo ano em que foi inaugurado o dispensário modelo Souza Campos matriculou-se na recém-criada faculdade de medicina da capital paulista, projeto que daria continuidade à política médico-sanitarista estadual por meio da formação dos profissionais da área. A fundação da faculdade de medicina representou, no jogo de posições do campo médico paulista, a transição de uma tradição ligada ao combate de epidemias para a nova solução saneadora médica -- a formação dos quadros médicos. Com essa nova abertura no campo, a área médica mostrou-se um caminho promissor a ser seguido, algo que Souza Campos compreendeu e tratou de associar-se, utilizando seus conhecimentos, ideais morais, políticos e a rede de sociabilidade adquiridos de sua origem familiar e formação profissional para construir sua carreira na medicina. 
As relações estreitas de amizade, de ideário político e de parentesco que a família de Ernesto mantinha com as famílias da elite republicana tanto em terras cariocas quanto paulistas permite-nos compreender as redes de sociabilidade de seu pai, que se estendeu consequentemente a seus descendentes. No tocante à trajetória intelectual de Ernesto de Souza Campos, é evidente que a inserção de sua família entre a elite política e ilustrada paulista, especialmente pela formação acadêmica e atuação pública de seu pai como médico e senador são elementos a considerar quanto a suas escolhas e posicionamentos políticos e institucionais. Como pudemos analisar, além da proximidade que seu pai tinha com as famílias Vieira de Carvalho, Brasiliense, Barreto, Paula Ramos e Mesquita por conta de seu cargo político, Antônio de Souza Campos também legislou sobre a instrução pública em seu mandato. Como representante da classe de produtores agrários do oeste paulista, assinou o projeto de criação de uma escola superior de agricultura para o estado, que serviria para a formação dos herdeiros da elite agroexportadora. Mesmo não sendo implantada conforme o projeto original, a formação em engenharia agronômica seria oferecida, por um curto período na Escola Politécnica. Como estudante e egresso dessa escola de engenharia, Souza Campos participou de importantes órgãos que congregaram os profissionais da área e possibilitaram a criação de laços sociais, de ofício e político-ideológicos entre os membros. Com a aprovação e implantação da Faculdade de Medicina e Cirurgia de São Paulo na década de 1910, Ernesto postulou-se ao curso médico e ali construiu relações com Arnaldo Vieira de Carvalho, filho do senador contemporâneo ao seu pai, tornando-se um expoente da primeira turma e posteriormente assumindo o papel de docente da instituição. As ligações político-ideológicas de Antônio Souza Campos com os republicanos Rangel Pestana e Júlio de Mesquita igualmente aproximavam a família Souza Campos de um importante núcleo da imprensa paulista -- o jornal A Província de S. Paulo, renomeado O Estado de S. Paulo, em 1890 -- periódico crucial nas primeiras décadas do século XX para a propaganda e organização dos debates em torno de projetos de educação republicana, como foi o caso da Faculdade de Medicina e Cirurgia. Na conjuntura da década de 1920, o diário dirigido por Júlio de Mesquita Filho liderou e agendou no debate público a campanha pela universidade estadual paulista, culminado com a fundação da Universidade de São Paulo em 1934, período em que Ernesto de Souza Campos foi partidário da causa. Ernesto de Souza Campos fez parte da elite herdeira dos republicanos de 1870 e construiu sua carreira nas instituições por eles idealizadas e criadas. 


\subsection{CONVERSÃO À “MÍSTICA MÉDICA”}

No contexto do início do século, a classe médica paulista arrogava para si a missão de curar não apenas o indivíduo mas a sociedade, em sua dimensão biológica e moral, seguindo a lógica de salvação nacional a partir de seu conhecimento específico. Por meio de um saber positivo, científico, o médico era um apóstolo do mundo civilizado, capaz de conduzir a sociedade pelos trilhos da modernidade, que passava pela higienização e regeneração do povo. Desta maneira, incorporaram-se às políticas públicas sanitárias o planejamento urbano e as análises sociais, movimento conceituado como medicalização da sociedade. Com o objetivo de retirar o brasileiro de seu estado mórbido e restituir-lhe o estado sadio necessário para o progresso e desenvolvimento econômico da nação, os médicos paulistas e seus representantes políticos procuraram organizar o sistema sanitário do estado, que deveria ser o exemplo para o resto do país. Entre campanhas sanitárias e criação de instituições que comporiam o aparelho médico sanitário paulista, a elite médica identificava como uma das necessidades a fundação de um instituto superior para a formação dos quadros de acordo com suas prerrogativas científicas e morais (MOTA, 2005).

Com a proclamação da República e a instauração do sistema federativo foi criado, em 1891, o Serviço Sanitário do Estado de São Paulo, órgão responsável por centralizar e orientar as ações sanitárias em âmbito estadual. Além das práticas sanitárias, a pesquisa médica para subsidiar as campanhas mostravam-se uma necessidade. Sendo assim, organizou-se o Instituto Vacinogênico e Laboratório de Bacteriologia, chamado posteriormente de Instituto Bacteriológico (CASA DE OSWALDO CRUZ/ FIOCRUZ, 2016).

A elite cafeeira, representada na política pelo Partido Republicano Paulista, propôs projetos de criação de escolas superiores oficiais a partir de 1891, entre elas a Academia de Medicina, Cirurgia e Farmácia de São Paulo, criada em dezembro daquele ano. Esta instituição, por ser parte do aparelho técnico e científico estadual, seria responsável pela formação dos quadros médicos necessários para a concretização das políticas sanitárias do estado. No entanto, por conta da deposição de Américo Brasiliense devido à queda de Deodoro da Fonseca, o projeto da escola médica foi adiado e só viria a ser regulamentado em dezembro de 1912, com o retorno de Rodrigues Alves ao governo do Estado após sua gestão na Presidência da República. O hiato de 21 anos que separaram os dois decretos foi marcado pelo debate entre os profissionais da área, políticos e imprensa sobre a necessidade de criação da instituição de 
ensino médico, com destaque ao periódico O Estado de S. Paulo, jornal que publicava artigos anônimos escritos por Arnaldo Vieira de Carvalho, importante personagem no movimento em prol da instalação da faculdade (MARINHO, 2013b, p.107).

Para Nadai (apud MOTA, 2005, p.181), a razão de não ter se implantado a faculdade em seu primeiro decreto teria sido a ideologia do progresso e modernização, que considerava prioritária a criação de escolas de engenharia, agricultura e comércio para a ordenação da política vigente. A área da saúde estaria contemplada com os serviços de profilaxia, que garantiriam o suprimento de mão-de-obra para a produção cafeeira e a indústria. A mudança de diretiva se deu quando o cenário político estadual ficou propício devido às ações de Rodrigues Alves, que deu continuidade em solo paulista à política saneadora que desenvolvera na capital da república com o auxílio de Oswaldo Cruz (MARINHO, 2013a, p.109). Conforme Marinho (2013b) a implantação da Faculdade de Medicina e Cirurgia de São Paulo foi a conquista da elite médica paulista que lutava pela instalação do projeto de formação de seus quadros com base em critérios científicos e experimentais, considerados cruciais para consolidar a capital paulista como centro propagador da regeneração nacional. Diferentemente de outras faculdades de medicina do país, que davam ênfase à clínica e às aulas teóricas, a FMCSP seria ancorada em um ensino que destacaria os estudos laboratoriais e a pesquisa, necessários para responder aos desafios da época.

Os debates promovidos pela imprensa paulista que antecederam a efetiva implantação da faculdade tiveram de resultar em ações concretas que consolidassem o projeto desejado de escola, pois tanto o impasse estabelecido anteriormente nas casas legislativas relacionado ao projeto da instituição quanto à promulgação da Lei Rivadávia Corrêa, de 1911, que instituiu o ensino livre, abriram espaço para a criação de uma universidade particular na cidade de São Paulo, que tinha como componente principal uma faculdade de medicina ${ }^{11}$. Assim, o tão sonhado projeto da escola médica oficial via-se comprometido por uma instituição concorrente, encabeçada por um grupo diverso e que não compartilhava diretamente da matriz política e da formação acadêmica considerada necessária para sustentar uma instituição de formação de

\footnotetext{
11 A primeira Universidade de São Paulo, criada em 1911, foi um estabelecimento privado, composto pelos cursos de medicina, direito, belas-artes, comércio, engenharia, odontologia e farmácia. A instituição foi fundada pelo médico e político positivista Eduardo Augusto Guimarães, em conjunto com uma sociedade de profissionais liberais e um sócio capitalista. A iniciativa recebeu duras críticas de parte da classe médica que, além de considerá-la uma ameaça ao projeto de escola médica ligada ao governo estadual, condenava sua organização, o corpo docente formado por farmacêuticos, a direção e os métodos de ensino utilizados pela instituição. (MOTA, 2005, p.171-174).
} 
quadros médicos. A reação à escola de medicina privada foi imediata e cindiu a Sociedade de Medicina e Cirurgia, que aglutinava a elite médica local. Arnaldo Vieira de Carvalho liderou o movimento de oposição e foi o principal articulador político para a criação da Faculdade de Medicina e Cirurgia de São Paulo, em contraposição à jovem escola particular. Utilizando-se de seu renome como diretor de órgãos que compunham o sistema sanitário paulista e de sua força política derivada de sua família, Carvalho negou qualquer apoio à faculdade privada e fundou a faculdade estatal sob seus auspícios ${ }^{12}$. Diferentemente daqueles que ampararam a iniciativa da universidade privada, o grupo representado por Arnaldo Vieira de Carvalho via na criação da faculdade de medicina pública a solução para a instalação de um ensino voltado para os interesses do estado e para a formação de quadros de excelência (MOTA, 2005, p. 172-177).

Foi nesse contexto que Souza Campos matriculou-se na Faculdade de Medicina. Com a abertura do curso médico em São Paulo, foi-lhe dada a chance de seguir a carreira de seu pai e a oportunidade de seguir estudos nas áreas das ciências naturais, com que tivera contato em seu primeiro curso de graduação. Além disso, estava engajado na construção de obras ligadas ao ideário médico-sanitarista, aproximando-o dos debates e questões voltadas área da medicina.

Já graduado como engenheiro, Souza Campos levou consigo a bagagem de conhecimentos das áreas da botânica, física, química e preparos técnicos de laboratório, que certamente lhe garantiram maior domínio da linguagem científica durante o curso de medicina. Este estofo conceitual somado a uma personalidade investigativa teria lhe proporcionado a “consagração" como melhor aluno da primeira turma da instituição, conquistando a classificação de grande distinção no curso preliminar, no primeiro e segundo anos do curso geral, e de distinção no terceiro e quarto anos ${ }^{13}$. Concomitantemente, Souza Campos construiu estreitos laços profissionais e afetivos com professores e médicos, além de manter-se durante toda a graduação na posição de aliado aos comandos do diretor Arnaldo Vieira de Carvalho, inclusive em situações expressivas de oposição ao seu projeto, que teriam posto em risco a consolidação da oficial Faculdade de Medicina.

\footnotetext{
${ }^{12}$ Arnaldo era filho de Joaquim José Vieira de Carvalho, bacharel e catedrático da Faculdade de Direito de São Paulo. Seu pai foi juiz da cidade de Campinas, cidade onde nasceu, deputado provincial de São Paulo, deputado estadual e senador no período republicano e vice-presidente da província de São Paulo nos governos de Rodrigues Alves e Francisco Antônio Dutra Rodrigues. Arnaldo Vieira de Carvalho foi formado pela Faculdade de Medicina do Rio de Janeiro, e em 1892 assumiu a diretoria do Instituto Vacinogênico em São Paulo. Em 1984, acumulou o cargo de diretor clínico da Santa Casa de Misericórdia e foi sócio fundador da Sociedade de Medicina e Cirurgia de São Paulo em 1895. Em 1913, fundou a Faculdade de Medicina e Cirurgia de São Paulo e assumiu como seu primeiro diretor (MOTA, 2005, p. 175-176).

${ }^{13}$ Boletim do Sr. Dr. Ernesto de Souza Campos [Fundo Ernesto de Souza Campos, Curriculum Vitae, Vol. I].
} 
No primeiro ano de funcionamento, a direção e o quadro docente da faculdade tiveram graves conflitos com os alunos, devido ao sistema de avaliação e notas. Arquitetado sob o molde do sistema usado na Escola Politécnica, com o qual Souza Campos era familiarizado, o processo avaliativo pretendia-se rigoroso para garantir a boa formação e a respeitabilidade pública de seus egressos. No entanto, entre o esperado e a realidade quanto à entrada dos estudantes existiu uma marcante lacuna: “a capital constatava o desnível entre o sonho da obtenção das ‘melhores cabeças', para que em solo paulista nascessem os melhores médicos, e a realidade de uma elite despreparada para os anseios civilizatórios” (MOTA, 2005, p. 195).

A polêmica em torno da avaliação poderia assim ser resumida: os exames parciais de física e química do professor Edmundo Xavier teriam ocorrido de forma inapropriada por conta da falta de espaço adequado, e acabaram resultando em elevada classificação abaixo da nota mínima. Como um estopim, a situação teria levado grande parte dos alunos a criticarem o sistema de avaliação, os professores Edmundo Xavier, Emile Brumpt e o próprio diretor da instituição. Em um jogo de forças entre a continuidade do funcionamento "normal” da instituição e as reivindicações dos alunos, que se configuraram em manifestações por meio de vaias em sala de aula e por depredações da clínica particular do Dr. Xavier, Vieira Carvalho foi obrigado a fechar as portas da faculdade por duas vezes, para acalmar a situação e tentar identificar os alunos insurgentes, o que desembocou na punição por um ano de todos os alunos pertencentes às duas turmas “revoltas”, dado a improfícua investigação e o receio de repreender apenas alguns descendentes de famílias de renome na sociedade paulistana. Entre os 95 alunos punidos, 59 recorreram e 34 terminariam suspensos. Desse processo de confronto entre o sonho de excelência em educação médica e a resistência dos alunos ao sistema avaliativo, resultou a eliminação de grande parte dos ingressantes, considerada pela classe docente e gestora como consequência “natural da seleção dos melhores alunos” da Faculdade, estes sendo os que se apresentaram ao diretor para repudiar os acontecimentos e manter-se ao lado das regras da instituição, entre os quais figura Souza Campos. De 180 alunos matriculados, seriam aprovados apenas 36 nos exames finais (MOTA, 2005, p. 195-198).

Souza Campos teria desempenhado papel decisivo no desenrolar das relações entre professores e alunos durante e depois da crise institucional que crivou a história da primeira turma da faculdade. O Centro Acadêmico Oswaldo Cruz, fundado em meados de 1913 e inicialmente composto por alguns alunos rebelados, foi reorganizado após o desligamento destes e implantada uma nova gestão, dirigida por Souza Campos, que permaneceria neste posto até 
1918. “Assim, o CAOC ganhou a missão de colaborar com a diretoria e os desígnios imputados pela escola, de modo a torná-la mais um exemplo de força e poder” (MOTA, 2005, p. 199).

Conforme apontou Souza Campos (1923, p.6), durante sua presidência no CAOC ele apresentou, executou e comandou o projeto da Revista de Medicina, publicando dez números do periódico, mantendo-a "sempre dentro dos limites científicos e procurando elevá-la ao nível das melhores publicações congêneres”. Podemos cogitar que a iniciativa de criar uma revista editada pelos alunos teria sido inspirada em sua vivência no Grêmio Politécnico da Escola Politécnica, que tinha entre suas ações a publicação da Revista Polytechnica. A Revista de Medicina, assim como no caso da similar politécnica, foi usada como forma de promover a produção discente e para criar vínculos acadêmicos e de reconhecimento entre alunos, professores e até mesmo com políticos. No caso da Revista de Medicina, esta era o símbolo da unificação entre alunos e professores em torno do projeto de uma faculdade médica paulista de excelência e referência para o país. O periódico, conforme consta em seu primeiro fascículo, tinha a função de garantir a divulgação de boas doutrinas, dos princípios que deveriam guiar os agentes da profissão e de representar a comunhão entre mestres e discípulos (MOTA, 2005, p. 199-200). Dessa maneira, cumpria a sua missão, enaltecendo a instituição e representando o clima amistoso buscado entre diretoria, alunos, professores e políticos, contra a instituída crise interna da Faculdade.

No período de sua presidência no Centro, Souza Campos comandou a campanha da comissão de alunos para a confecção do estandarte da faculdade (CAMPOS, 1923, p.6-7). Unindo os símbolos nacionais e as insígnias que caracterizavam a profissão médica, o estandarte tornou-se um emblema da "tradição” que a novel faculdade criava para si. Iniciativa do Centro Acadêmico, o estandarte acabou acolhido pela Congregação e tornou-se uma representação da distinção e autoridade científica da Faculdade (MOTA, 2005, p. 204-207).

Algumas personagens centrais no desenrolar das decisões acadêmicas e políticas da Faculdade de Medicina de Cirurgia de São Paulo na década de 1910 e 1920 mantiveram laços acadêmicos e pessoais estreitos com Souza Campos e contribuíram para sua trajetória ascendente na instituição que, em 1925, culminaria com a nomeação para o cargo de professor catedrático.

Quando ainda aluno interno na enfermaria da Santa Casa de Misericórdia a convite de Ovídio Pires de Campos, professor responsável pela $2^{\text {a }}$ cadeira de Clínica Médica, Souza Campos publicou trabalhos em colaboração com Pedro Dias da Silva, à época assistente 
voluntário da mesma sessão. Souza Campos e Dias da Silva foram orientados pelo mesmo docente, trabalharam juntos na mesma ala hospitalar e desenvolveram laços de amizade (CAMPOS, 1954, p.347; p.362) que se estenderam pelos anos seguintes, especialmente no período em que Pedro Dias da Silva foi nomeado diretor da Faculdade de Medicina.

Ovídio Pires de Campos exerceu papel fundamental na consagração e consolidação de Souza Campos como aluno de "destaque" da primeira turma e, posteriormente, como docente na faculdade. O médico foi contratado por Arnaldo para lecionar Fisiologia e Patologia Geral em 1914, tornando-se catedrático no ano seguinte. Homem de confiança do diretor, foi nomeado vice em 1918, assumindo a direção em julho de 1920, após a morte do patrono, em momento delicado da instituição (MUSEU HISTÓRICO DA FACULDADE DE MEDICINA, 2016).

Conforme o relato de Souza Campos (1954, p. 348) “estreitamente ligados a Ovídio Pires de Campos, por uma amizade que ali começou e se manteve até seu passamento, tomamos contato direto com o Dr. Arnaldo”. Exercendo a presidência do centro acadêmico por cinco anos, Souza Campos tratou diretamente com Arnaldo de questões que envolviam a estabilidade de recém-criada instituição, como a procura por uma sede própria e adequada para as aulas e a harmonização entre alunos e professores.

[...] não raro comparticipamos (sic) na solução de vários problemas surgidos na época. Com Arnaldo, no seu próprio carro, percorremos vários pontos e casas de São Paulo, à procura de uma sede definitiva. Na séria questão que se levantou, em consequência da atitude de um mestre contratado, exercemos duas vezes missão de confiança. Na primeira, para impedir que estudantes agissem contra aquele professor por ocasião da declaração de guerra, do Brasil contra a Alemanha, na primeira guerra mundial. O professor era de naturalidade austríaca, mas tinha formação alemã e por alemão ${ }^{14}$ passava. Arnaldo chamou-nos ao seu escritório, na rua de São Bento, quase na hora em que a manifestação se preparava. Corremos para o local. Procuramos os líderes. Eram dois distintos colegas. Informados da atitude enérgica de Arnaldo, ameaçando demitir-se caso se realizasse a agressão, imediatamente transformaram

\footnotetext{
${ }^{14}$ Pelas características apresentadas por Souza Campos, deduzimos que o professor em questão era Walter Haberfeld. A querela entre os alunos e o professor continuou. Souza Campos expôs em detalhes: "Na segunda vez, fomos encarregados de obter, do mesmo professor, sua demissão, em vista da repercussão que tiveram suas palavras, em aula, contra eminente personalidade de São Paulo. Não teve êxito nossa empreitada, como também não obteve um professor que depois recebeu idêntica missão. E o caso só se resolveu depois da morte de Arnaldo, pela voluntária exoneração do mestre. Arnaldo era muito cioso da sua situação de hospedeiro. Tendo contratado um professor estrangeiro considerava-se responsável por qualquer motivo que escolarmente pudesse atingir” (CAMPOS, 1954, p. 348). De acordo com seu memorial, Souza Campos foi aluno interno voluntário do Instituto de Anatomia Patológica da Faculdade de Medicina, à época sob a direção do professor Walter Haberfeld (CAMPOS, 1923, p.9).
} 
aquela espécie de comício em passeata pelas ruas da cidade, sem maiores complicações (CAMPOS, 1954, p.348).

Ocupando o posto estratégico de representante estudantil e utilizando de sua autoridade e conhecimentos como engenheiro, Souza Campos auxiliava na busca por uma espaço próprio para a Faculdade e agia em nome de Arnaldo para apaziguar conflitos internos da casa. Quanto à relação com Arnaldo Vieira de Carvalho e Ovídio Pires de Campos, Souza Campos reafirmava sua posição de seguidor e admirador, proximidade que teria como base a ligação acadêmica, mas que ao fundo apresentava uma convergência política, institucional e moral:

Nessa meia intimidade, mantido absoluto respeito do discípulo pelos mestres, embora já fosse também graduado por uma escola superior de São Paulo, nessa meia intimidade, repetimos, tivemos a possibilidade de privar com os dois máximos formadores e organizadores da nossa Faculdade de Medicina. É de apreciar o devotado empenho de Arnaldo e Ovídio em construir sólidas bases que permitissem, como permitiram, o êxito maravilhoso alcançado na hora presente, igualada, como está, as melhores escolas de ensino médico do mundo, especificamente dos Estados Unidos da América do Norte” (CAMPOS, 1954, p. 348).

Claramente adepto e apoiador do projeto de Arnaldo, Ernesto de Souza Campos era um símbolo do "sucesso" do empreendimento da faculdade médica oficial paulista. Com notas de alto rendimento, comportamento exemplar e ativismo pró instituição, sua trajetória representava a vitória do plano institucional. Decorrência disto foi sua "natural” indicação ao quadro de docentes, logo após sua titulação ${ }^{15}$.

Em 26 de fevereiro de 1919, Souza Campos defendeu a tese de doutoramento Doença de Rustizky-Kahler (Myeloma) vinculada às cadeiras de Anatomia Patológica e Clínica Médica, sob a orientação de Walter Haberfeld e colaboração de Ovídio Pires de Campos. Segundo registro jornalístico, a defesa foi feita perante a congregação da Faculdade, o presidente do estado, Altino Arantes, e o secretário do interior, Oscar Rodrigues Alves. Ovídio Pires de Campos, que compunha a banca, teria elogiado o trabalho, afirmando que Souza Campos deveria, pela qualidade da obra, estar no lugar de catedrático e não de examinado ${ }^{16}$. Logo em seguida, em 6 de março de 1919, Souza Campos fora nomeado preparador na Faculdade de Medicina na vaga anteriormente ocupada por Diaulas de Souza e Silva, da cadeira de Histologia

\footnotetext{
${ }^{15}$ Importante é ressaltar que as instituições de ensino superior estavam organizadas em cátedras, e o catedrático responsável de cada cadeira tinha total liberdade de escolher seus assistentes, como cargo de confiança. Além disso, a nomeação de docentes poderia ser feita diretamente pelo diretor da faculdade, sem a necessidade de concurso público (MOTA, 2005, p.190).

${ }^{16}$ O PRIMEIRO doutor pela Faculdade de Medicina, 1919?. [Fundo Ernesto de Souza Campos, Curriculum Vitae, Vol. I].
} 
Normal, comandada por Alfonso Bovero. Após ter sido aprovada com distinção e louvor, a tese foi apresentada na Sociedade de Medicina e Cirurgia de São Paulo, e o jovem doutor recebeu o prêmio “Dr. Sérgio Meira” pela melhor tese defendida na Faculdade de Medicina de São Paulo (CAMPOS, 1919) $)^{17}$. Tornava-se, assim, maduro o fruto da medicina paulista, pronto para agir, por meio de seu conhecimento científico, na cura da sociedade rumo à modernidade.

\subsection{DIÁlogos COM A ARQUITETURA E EMBATES COM A “MISSÃO SOCIAL DO ARQUITETO”}

Ao longo das décadas de 1920 e 1930, Souza Campos passou a atuar não apenas como engenheiro e médico, mas utilizou esses títulos e conhecimentos a serviço de uma causa maior, a da educação superior, questão que tomou conta do debate público no período e que foi um dos principais objetos de disputas políticas e ideológicas entre as elites como elemento de modernização nacional. Dessa maneira, progressivamente Souza Campos passou a atuar como intelectual, ao abraçar a causa educacional em sua forma universitária. O preâmbulo desse engajamento deu-se no início de sua carreira na Faculdade de Medicina, convidado a viajar para o Estados Unidos como fellow da Fundação Rockefeller. Esta experiência marcou em seu “espírito” o modo de ser universitário norte-americano, suas estruturas espaciais, científicas e didáticas, tendo conhecido uma das principais especificidades do ensino superior norte-americano: o campus universitário (PINTO; BUFFA, 2009). Ao assumir o papel de idealizador e construtor de estruturas espaciais de ensino universitário, Souza Campos atuou diretamente no campo da arquitetura. Este passava por uma redefinição interna, na qual o estilo eclético e o neocolonial eram suplantados pelo estilo moderno, que buscava ascender às principais posições e configurar a autonomia do campo em relação aos domínios da engenharia e das belas artes, identificando-se com o movimento moderno internacional.

A aproximação de Souza Campos com o campo da arquitetura pode ser remontado ainda à década de 1910, por meio das construções dos grupos escolares e do dispensário modelo. Naquele momento, desde o final do século XIX, o estilo eclético era utilizado pela elite paulista como sinônimo de modernidade (THEODORO, 1996; FABRIS, 1995; MELLO,

\footnotetext{
${ }^{17}$ O prêmio foi criado, em 1917, após a morte do médico Sérgio Florentino de Paiva Meira, primeiro Inspetor do Serviço Sanitário de São Paulo e fundador da Sociedade de Medicina e Cirurgia de São Paulo. Destinava-se para a melhor tese de doutoramento defendida na Faculdade de Medicina de São Paulo (ACADEMIA DE MEDICINA DE SÃO PAULO, 2016). Ao que tudo indica, Souza Campos foi o primeiro a receber o prêmio, pois era aluno da primeira turma.
} 
2006). O principal representante desta vertente no campo arquitetônico paulista foi o Escritório Técnico Ramos de Azevedo, Severo \& Villares, responsável pela construção de dezenas de prédios públicos que se tornaram símbolo da modernização e urbanização da cidade de São Paulo na virada do século. Entre eles constam, somente no setor educacional, a Escola Politécnica (Edifício Ramos de Azevedo, 1912-1920), a sede dos Laboratórios da Escola Politécnica (Edifício Paula Souza, 1895-1896), o Liceu de Artes e Ofícios (atual Pinacoteca do Estado, 1897-1900), a Escola Normal (Caetano de Campos, 1892-1894), a Faculdade de Direito (1933) (BUENO, 2015) e a sede da Faculdade de Medicina, inaugurada em 1931.

O Escritório chegou a ter filiais em Santos e no Rio de Janeiro e durante 42 anos foi liderado por Ramos de Azevedo (1886-1928), 12 anos por Ricardo Severo (1928-1940), 25 anos por Arnaldo Dumont Villares (1940-1965) e os últimos 15 anos pelos politécnicos Dr. Roberto Pereira de Almeida e Affonso Iervolino. No amplo leque temporal de existência, alinhou-se ao que havia de mais moderno em termos de arquitetura, destacando-se pela adesão ao ecletismo na sua primeira fase [...]. A arquitetura eclética envolvia novos procedimentos e mão de obra especializada e, nesse aspecto, a vinculação dos protagonistas com a Poli[técnica] e o Liceu [de Artes e Ofícios] foi essencial para a formação de quadros técnicos capazes de dar cabo à nova estética. Pelo Escritório passaram os melhores profissionais, polarizando inclusive artesãos imigrantes recém-chegados e relacionados aos mais diversos ofícios (BUENO, 2015, p.198-199).

A arquitetura eclética, por sua natureza de composição de estilos e temporalidades diversas, tinha em si um componente de apropriação, de livre interpretação e elaboração de elementos estrangeiros (FABRIS, 1995, p.74). Portanto, um dos pontos do estilo eclético era a repúdio ao estatuto colonial e a busca pelo espelhamento na arquitetura europeia, por uma ação ordenadora do espaço que não mais se alicerçava no passado. Dessa forma, o campineiro Ramos de Azevedo, docente e diretor da Escola Politécnica e do Liceu de Artes e Ofícios, filiou suas obras à tradição arquitetônica europeia, derivada da formação na Universidade de Gante, na Bélgica. Por essa razão, preocupou-se mais com o uso dos materiais e dos espaços de acordo com as necessidades do que era executado, buscando uma "razão construtiva” no lugar de polêmicas de estilo (THEODORO,1996). A marca de Ramos de Azevedo manter-se-ia no escritório técnico por longo período, mesmo após sua morte, em 1928, quando assume o português Ricardo Severo, momento da execução do prédio da Faculdade de Medicina projetado por Ernesto de Souza Campos. 
Ricardo Severo, além de sócio ativo, foi continuador da obra que Ramos de Azevedo edificara a partir do final do século XIX e que transformara profundamente o cenário arquitetônico da capital paulista, apagando sua feição colonial e tornando-a uma capital “atualizada”, seguindo os moldes das cidades européias de feição eclética e universalista. Curiosamente, como se vê, foi no interior deste processo de modernização capitalista e beaux-arts da cidade, que transformou sua paisagem arquitetônica, pública e burguesa, dando-lhe um caráter cosmopolita, para muitos, como o próprio engenheiro, demasiadamente estrangeiro, que Severo se tornou o chefe de fila da arquitetura “tradicional” no Brasil, de caráter nacional. (MELLO, 2006, p.84-85).

Severo manteve relações estreitas de amizade e parentesco com a elite ilustrada paulista, e atuou não somente na construção arquitetônica mas como pensador da cultura brasileira, sendo membro do Instituto Histórico e Geográfico de São Paulo e aproximando-se do núcleo do jornal O Estado de S. Paulo. Nesse bojo, característico da ambiguidade existente no contexto histórico da época e que colocava em discussão o fator da nacionalidade, mesmo produzindo obras no estilo eclético, Severo projetou um discurso inovador, criando o movimento neocolonial, que ficaria conhecido como “campanha de arte tradicional”, na defesa de um lado pela valorização do passado e das tradições nacionais, e de outro, pela proposição de uma arte nacional presente e futura (MELLO, 2006) ${ }^{18}$.

A incoerência do discurso e da prática arquitetônica de Severo aponta para a ambivalência do engenheiro na definição do nacional/estrangeiro, local/universal, tradicional/cosmopolita, mostrando que esta era uma questão em aberto. [...] esta ambivalência revela o quadro de intensa disputa em torno da construção da modernidade, universalidade e/ou nacionalidade artística entre nós naquele momento (MELLO, 2006, p.85).

Do lado oposto dos defensores do neocolonial estavam os modernistas, ambos na disputa pelo controle do campo e do signo do moderno, contra o que passou a ser considerado como velho e fora de nossas tradições: o estilo eclético. Tanto o discurso do neocolonial quanto do moderno partiram à busca por uma expressão do nacional, preocuparam-se em conhecer e recuperar o passado para fundar uma arquitetura nacional por meio de uma reinterpretação e atualização. Dessa maneira, a procura de Severo foi compartilhada, entre companheiros e críticos, por Alexandre de Albuquerque, Adolpho Morales de los Rios, Lúcio Costa, Monteiro

\footnotetext{
${ }^{18}$ Como elemento do projeto de modernização e modernidade nacional, "a arquitetura neocolonial, em São Paulo, começava assim a se afirmar como um produto cultural erudito, gestado, discutido e consumido num circuito cultural e institucional bem definido: o Liceu de Artes e Ofícios, o Escritório Técnico Ramos de Azevedo, a Sociedade de Cultura Artística, o jornal O Estado de São Paulo, a Revista do Brasil, o Instituto Histórico e Geográfico de São Paulo. Geograficamente, a produção construída se resume a residências que se distribuem pelos bairros chics da capital e pelos balneários do litoral” (KESSEL, 2002, p.118-119).
} 
Lobato, Mário de Andrade e Manuel Bandeira. No caso de Lúcio Costa, ícone da arquitetura moderna a partir de 1930, foi seguidor do neocolonial durante a formação estudantil, mas ao assumir a direção da Escola Nacional de Belas Artes, no Rio de Janeiro, passou a defender a vertente moderna. Para os dois grupos, era unânime que a raiz da arquitetura brasileira deveria ser assentada na produção feita desde o descobrimento, em especial no barroco mineiro, resgatada após o período de interrupção do ecletismo. A diferença residia na questão de qual movimento retomava esse fio: o neocolonial ou o moderno (MELLO, 2006, p.95 -97).

Foi nesse contexto que a obra projetada por Souza Campos para a Faculdade de Medicina foi idealizada e executada. Ao Escritório Técnico Ramos de Azevedo foi entregue a construção do prédio, feito entre os anos de 1926 e 1931. Mesmo liderado por Severo, defensor do neocolonial, a obra permaneceu com a marca da elite ilustrada paulista, ou seja, o estilo eclético, especificamente o neo-Tudor, de origem inglesa. O primeiro projeto para a sede própria da Faculdade, datado do final da década de 1910 sob o comando de Arnaldo Vieira de Carvalho, também havia sido confiado ao escritório de Ramos de Azevedo. Naquele momento, a proposta foi de construir cinco pavilhões separados de acordo com a especialidade de cada ramo, correspondendo ao modelo tradicional de ensino médico. Dos cinco, apenas o edifício da Medicina Legal, hoje Instituto Oscar Freire, foi construído e abrigou essa cátedra até 1924, quando cedeu o lugar a outras disciplinas. Esta unidade apresenta características da arquitetura eclética, com elementos neo-românticos (KATINSKY; SILVA; COSTA, 2013, p.19-20). Com a introdução do modelo de ensino médico da Fundação Rockefeller e a exigência de seguir seu padrão de ensino e pesquisa, o segundo projeto da faculdade, elaborado por Ernesto de Souza Campos “representou um grande avanço em relação ao desenho do edifício, estrutura acadêmica e orientação pedagógica. O edifício foi construído de maneira inovadora para a época, pelas suas dimensões, sistema construtivo e técnicas aplicadas” (KATINSKY; SILVA; COSTA, 2013, p.23).

Mesmo sendo uma obra inovadora, a fachada do prédio permaneceu seguindo a tradição eclética. Quanto a escolha desse estilo, podemos conjecturar algumas razões: o prédio estaria em consonância com o princípio de universalidade e modernidade europeia, como um vínculo simbólico; o ordenamento da planta foi feito a partir do olhar médico de Souza Campos, buscando corresponder às necessidades de ensino e pesquisa da faculdade de acordo com uma visão científica do espaço, algo que foi mantido na construção como sendo sua "razão construtiva”; e por fim o uso do neo-Tudor, uma corrente do eclético, utilizado nos Estados 
Unidos durante as primeiras décadas do século XX (WATKIN, 2005), país da Fundação Rockefeller, que financiou a obra e as viagens de estudos onde Souza Campos baseou seu projeto. De acordo com Thelin (2004), as universidades norte-americanas utilizaram o estilo eclético, expressão do colonial revivalism na construção de edifícios simbólicos em seus campi, como forma de demonstrar a herança histórica advindas das formações dos college coloniais, que garantem, por meio do recurso à memória de uma saga institucional, prestígio, autoridade e distinção. Esse prédios, aliados aos seus rituais, personagens e episódios da história, são reconhecidos como monumentos nacionais. Escolhendo o estilo neo-Tudor, Souza Campos criava a herança simbólica entre a Faculdade de Medicina e seu patrocinador, como homenagem e filiação à medicina norte-americana.

Na ocasião do lançamento da pedra fundamental, em 25 de janeiro de 1928, por sua monumentalidade e modernidade, a sede dos laboratórios da escola de medicina rendeu a Souza Campos repercussão na imprensa, tanto por meio de críticas por parte de arquitetos quanto elogios por parte de Mário de Andrade ${ }^{19}$, colunista de $O$ Diário Nacional sobre Arte e de $O$ Estado de S. Paulo. Assim, estes últimos assinalavam a grandiosa obra prima da arquitetura paulista: segundo OESP, “achávamos diante de um projeto grandiosamente concebido, e, o que mais importa, estudado e ideado para as necessidades e as exigências do ensino médico de $\mathrm{S}$. Paulo!”20. Para Mário de Andrade, sua “impressão é que a Faculdade de Medicina paulista vai ficar um dos trechos mais monumentais da terra brasileira tratada por mão de homem”; com esta obra "vamos ficar com um monumento arquitetônico de muito valor. De valor extraordinário no Brasil. A arquitetura é talvez, de todas as artes, aquela que tem menos obras de valor no Brasil. Não vejo quase nada que me impressione de deveras"21.

\footnotetext{
${ }^{19}$ Em entrevista para o Jornal do Campus (MANZALLI, 2008), da Universidade de São Paulo, a equipe de restauro do prédio da faculdade classificou o valor arquitetônico da obra: "A Faculdade de Medicina da USP, construída pelo escritório Ramos de Azevedo e inaugurada em 1931 com fachada em estilo neo-Tudor, é tombada pelo Condephaat desde 1981 não só por sua arquitetura. 'A Faculdade representa pouco para a arquitetura, é um projeto modesto. Mas para a cultura de São Paulo, ele é muito importante. Foi o maior prédio feito na época pelo governo, e para abrigar uma escola!', explica Julio Roberto Katinsky, professor da FAU e um dos responsáveis pelo restauro do prédio desde 2004. Sua irmã e também arquiteta da equipe, Thereza Katinsky, afirma que o prédio não foi inovador. 'Em relação à arquitetura, o prédio já era desatualizado quando foi feito. Naquela época, o modernismo já estava consolidado'. Helena Ayoub Silva, a terceira arquiteta a compor o time de restauro, completa apontando a mistura única da construção. 'A estrutura do prédio é independente, modulada e flexível - e isso são preceitos modemistas. Mas a fachada é demodée. Talvez por isso o tombamento; por essa necessidade de colocar uma fachada mais palatável para as pessoas da época”’.

${ }^{20}$ O Estado de S. Paulo, Faculdade de Medicina, 25 de janeiro de 1928 [Fundo Ernesto de Souza Campos. Curriculum Vitae, vol I].

${ }^{21}$ Diário Nacional. Arte - Arquitetura Brasileira, 28 de janeiro de 1928 [Fundo Ernesto de Souza Campos. Curriculum Vitae, vol I]. Naquele ano, Mário de Andrade dedicou uma série de artigos intitulada Arquitetura
} 
Se para representantes da intelectualidade paulista o projeto da sede da faculdade era considerado um avanço arquitetônico e médico, houve quem o visse com críticas e ressalvas, marcadamente o grupo de profissionais da arquitetura, anunciando uma indisposição com a atuação de Souza Campos que se intensificou na década de 1930. De acordo com O Jornal,

Há dias, tivemos oportunidade de colher uma entrevista de um punhado de conhecidos arquitetos paulistas sobre o projeto das novas instalações da Faculdade de Medicina. Vários pontos dele mereceram críticas acerbas e houve até dentre os arquitetos, quem chegasse ao extremo de afirmar que as novas construções estariam em desacordo com disposições do Código Sanitário do Estado ${ }^{22}$.

Souza Campos defendeu-se, afirmando serem infundadas as críticas, pois seu projeto era um novo tipo aplicável ao gênero médico, decorrente de extensivo estudo comparativo. Por essa razão, diferente do primeiro projeto da faculdade, Souza Campos optou por centralizar os laboratórios em um único prédio, em cooperação com o hospital. Neste bloco único de laboratórios, as cadeiras afins seriam unidas, obedecendo aos planos que partiram de cada sala, de suas minúcias para o ensino e pesquisa ${ }^{23}$. Percebemos que, ainda no momento de elaboração e construção do edifício da faculdade, a definição dos traços identitários da arquitetura moderna era imprecisa e ambígua, pois obras de estilo eclético eram consideradas por parte da intelectualidade como representantes desse movimento. No entanto, o "sentido de moderno" vai se deslocando progressivamente, por meio do discurso de ruptura com o passado eclético, ganhando uma nova roupagem, agora nacional, mas em sintonia com os movimentos da arquitetura moderna internacional (FABRIS, 1995). No Brasil, a arquitetura moderna, inspirada nos escritos de Le Corbusier, teve expressões em São Paulo e no Rio de Janeiro, com os manifestos dos arquitetos Rino Levi e Gregori Warchavchik e a partir das reformas que Lúcio Costa tentou implementar em sua passagem pela direção da Escola Nacional de Belas Artes, sacramentando a palavra "modernista" como sinônimo de uma arquitetura funcional, sem ornamentação, despojada e geométrica, de formas clara e puras do clássico mediterrâneo, que utiliza o concreto armado e dispensa qualquer elemento da antiga arquitetura colonial, pois está ancorada nos valores da máquina: racionalidade da construção somada a beleza das formas e

Colonial, em que se põe a reavaliar o estilo neocolonial frente a disputa com a vertente futurista moderna. Como conclusão, defende a adoção do neocolonial como forma brasileira de arquitetura (KESSEL, 2002).

${ }^{22}$ O Jornal. O palácio da Faculdade de Medicina, 11 de fevereiro de 1928[Fundo Ernesto de Souza Campos. Curriculum Vitae, vol I].

${ }^{23}$ O Jornal. O palácio da Faculdade de Medicina, 11 de fevereiro de 1928[Fundo Ernesto de Souza Campos.

Curriculum Vitae, vol I]. 
das linhas (KESSEL, 2002; FABRIS, 1995).

A vertente que historicamente ficou conhecida como arquitetura moderna, especialmente a partir da década de 1930, passou a disputar com a tradição eclética e o movimento neocolonial o controle do campo e, consequentemente, do poder de encetar suas marcas sobre os espaços arquiteturáveis e sobre o modo de vida da sociedade. A “missão social do arquiteto", que teria nascido com a introdução da causa social pela arquitetura moderna, ganhou contorno em sua relação com obras do Estado e seu caráter nacionalista, e atingiu seu auge nos anos 1950 e 1960. Conforme aponta Kopp (1990, p.15-16, itálicos do autor), arquiteto moderno russo formado na França e nos Estados Unidos, o movimento da arquitetura moderna,

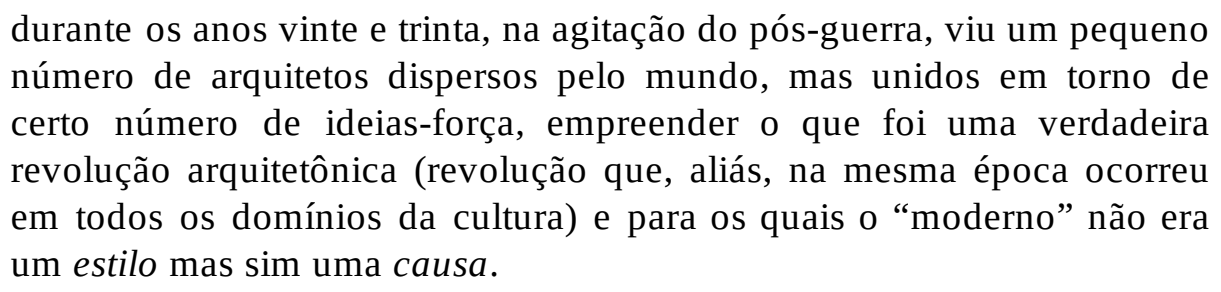

Essa revolução arquitetônica passou a ser identificada com a revolução política e social, marcadamente de esquerda, tendo suas maiores expressões nas vanguardas construtivistas da Rússia comunista, os funcionalistas na Alemanha da República de Weimar e os membros do L'Esprit Nouveau francês. Das três vertentes, a vanguarda francesa foi a que mais se aproximou dos arquitetos modernos brasileiros, em especial pelo contato com Le Corbusier. Por ser um movimento diminuto em termos quantitativos -- não correspondeu a um grupo de profissionais mas a duas personalidades, Le Corbusier e André Lurçat -- e de pouca aplicabilidade em seu território, pois a França não vivenciou as transformações políticas e econômicas da Rússia e da Alemanha, L’Esprit Nouveau procurou atuar em outros países, por meio do convívio com Le Corbusier, que abria seu escritório como espaço de reflexão para estágios estrangeiros (KOPP, 1990).

A arquitetura moderna, dessa maneira, assumiu feições de mecanismo de reconstrução social, pois não mais reverenciava um passado, mas criava uma nova sociedade por meio da construção de novos espaços urbanos, formando uma "crença nas virtudes pedagógicas do ambiente construído considerado como um instrumento de transformação social” (KOPP, 1990, p.17). Estava assentada nessa crença a “missão social do arquiteto”. Para Tafuri (1985), embora o movimento moderno tenha se associado às preocupações revolucionárias, teve em sua base a 
estrutura do capitalismo industrial urbano, contribuindo sobremaneira para sua reconstrução nos pós-guerras. No caso brasileiro das décadas de 1930 a 1950, será a expressão máxima do desenvolvimento econômico, substituindo a preocupação da causa social pela causa nacional.

Por ter trabalhado nos projetos das cidades universitárias da Universidade do Brasil e da Universidade de São Paulo, Souza Campos tomou contato com o movimento da arquitetura moderna em seu momento de introdução e consolidação no campo, inclusive como afirmação da arquitetura em relação à engenharia e as belas artes. As cidades universitárias foram, como obras governamentais e símbolos de modernidade, objetos de disputa pelo grupo dos modernos nas capitais paulista e federal, de acordo com as especificidades do campo da arquitetura de cada localidade. Na universidade paulista, Souza Campos foi designado por Armando de Salles Oliveira à comissão da cidade universitária, sendo seu relator e principal idealizador, além de diretor do Escritório Técnico que projetou os primeiros planos, de acordo com os princípios defendidos pelos fundadores da USP. No Rio de Janeiro, Lúcio Costa liderou um contra-ataque ao projeto de cidade universitária feito por Marcello Piacentini, a convite de Gustavo Capanema, e planejado pela comissão de professores responsável pelos planos da universidade, entre os quais estava Souza Campos. A atuação de Ernesto de Souza Campos na concepção das cidades universitárias e os embates com o campo da arquitetura moderna serão abordados detalhadamente no capítulo terceiro. 


\section{A INVESTIDURA DA MISSÃO: A REFERÊNCIA DO MODELO UNIVERSITÁRIO NORTE-AMERICANO $\mathrm{E}$ O APOSTOLADO PELA UNIVERSIDADE}

A ascensão da carreira de Ernesto de Souza Campos no campo médico paulista está intimamente conectada com a história do estabelecimento do modelo de educação médica da Fundação Rockefeller na Faculdade de Medicina e Cirurgia de São Paulo. Inicialmente como beneficiário de bolsa de estudos da entidade em solo norte-americano e posteriormente como protagonista nas negociações entre as instituições para a construção da sede da faculdade, Ernesto de Souza Campos participou ativamente, em colaboração com outros sujeitos, da consolidação do modelo norte-americano de medicina na terra bandeirante.

Um momento importante e decisivo em sua trajetória acadêmica foi a estada na Escola de Medicina da Universidade Johns Hopkins, na cidade de Baltimore, Estados Unidos, entre os anos de 1920 e 1922. Além da viagem ter sido um marco em sua carreira de pesquisador, foi parte decisiva das negociações entre a Faculdade de Medicina e Cirurgia de São Paulo e a Fundação Rockefeller e compôs o quadro de relações entre as duas instituições, tanto quanto no movimento de filantropia científica da instituição norte-americana na América Latina.

A partir de 1925, após seu retorno ao Brasil de viagem comissionada pela Faculdade e pela Fundação Rockefeller para estudos dos centros médicos e universitários na América do Norte e Europa e de sua colocação como catedrático na Faculdade de Medicina, Souza Campos trouxe consigo uma bagagem de conhecimentos sobre a organização do ensino superior no estrangeiro, da qual utilizou para inserir-se no movimento pela criação da universidade em São Paulo. A experiência de ter visitado, observado e estudado essas instituições estrangeiras tornou-se seu principal instrumento e repertório argumentativo para discorrer e engajar-se na causa universitária, missão que designou como seu “apostolado” pela universidade.

\subsection{NUANCES DA APROXIMAÇÃO COM A FUNDAÇÃO ROCKEFELLER}

A Fundação Rockefeller está no cerne do movimento da filantropia científica, isto é, a destinação de recursos privados para a atuação em interesses públicos, no caso, a produção de conhecimento científico (MARINHO, 2001, p. 14). Conforme apresentou Farley (2003, p.4), para os membros da Fundação Rockefeller era claro que a filantropia não era caridade, mas um investimento feito com agências governamentais para estimular a auto-ajuda e a independência 
das instituições. Por isso, os receptores teriam de se comprometer a perpetuar o trabalho iniciado após o recebimento do auxílio ${ }^{24}$.

A Fundação Rockefeller foi organizada em 1913, a partir do reagrupamento das juntas filantrópicas da família Rockefeller que existiam desde o século XIX, responsáveis por ações voltadas à saúde pública, educação geral, economia e relações industriais. A partir do final da Primeira Guerra, suas atividades concentraram-se na educação médica e na saúde pública. Sob a coordenação de Wickliffe Rose, a Junta Internacional de Educação (International Education Board) foi destinada a promover o desenvolvimento das áreas das ciências físicas, biológicas e agricultura. Em 1928, após reestruturação, foi organizada em cinco departamentos: Ciências Naturais, Ciências Sociais, Ciências Médicas, Humanidades e Departamento Internacional de Saúde, somando-se ao IEB, que estava independente. As ações desenvolvidas pela fundação foram responsáveis pela institucionalização e pelo financiamento da produção científica mundial, que deslocou seu eixo da Europa para os Estados Unidos no período entreguerras. Suas doações foram responsáveis pelo estabelecimento da ciência moderna nos Estados Unidos e pelo financiamento de atividades científicas nas universidades norte-americanas e estrangeiras. Ainda na década de 1910, a Rockefeller iniciou seus investimentos em campanhas sanitaristas e em educação médica na América Latina, sendo instituição preponderante no desenvolvimento da ciências médicas, biológicas e físicas no estado de São Paulo, em especial na Faculdade de Medicina e, a partir de década de 1940, na Universidade de São Paulo (MARINHO, 2001).

De 1913 a 1951, os investimentos da Fundação Rockefeller para a área da saúde foram administrados por uma junta, inicialmente chamada de International Health Commission (1913-1916), denominada posteriormente de International Health Board (1916-1927) e International Health Division (1927-1951). Quando a junta foi dissolvida, sua equipe havia trabalhado em oitenta países: Estados Unidos e Canadá, vinte e cinco países da Europa, quinze no Caribe, todos os países da América Central e Latina, dezenove na Ásia e alguns na África e Oriente Médio. O principal foco da junta foi a erradicação de epidemias como ancilostomíase, malária, febre amarela e tuberculose e o consequente treinamento de médicos e enfermeiros para

\footnotetext{
${ }^{24}$ Para Stepan (2011, p.471-472), os trabalhos acadêmicos produzidos sobre as ações filantrópicas da Fundação Rockefeller podem ser classificados em três diferentes perspectivas: a primeira, laudatória da política institucional, que enxerga a atuação da Rockefeller por meio dos valores filantrópicos e valoriza seus “sucessos” no campo da Saúde Pública e da Medicina; a segunda, que a autora adjetivou como “imperialista”, situado no outro extremo por meio de uma crítica acentuada à instituição, negando a ideia do humanitarismo e destacando suas ações como instrumento do imperialismo norte-americano; e a terceira, que propõe uma visão historiográfica a partir dos países contemplados sem negar a ideia do imperialismo, buscando as ambiguidades das negociações, de acordo com os contextos e agentes locais.
} 
o trabalho em Saúde Pública. Para a formação desses profissionais eram oferecidas bolsas de estudos nos Estados Unidos e na Europa (FARLEY, 2003, p.2).

De acordo com Marinho (2013b, p.88; p.114-117), os acordos travados entre a Fundação Rockefeller e a Faculdade de Medicina e Cirurgia de São Paulo tiveram início em 1916, com o pedido de apoio ao estabelecimento das cadeiras de Higiene e Patologia por Arnaldo Vieira de Carvalho. Apesar do pedido ter partido da instituição beneficiada, a fundação já havia mostrado interesse em investir no Brasil após a deliberação das primeiras comissões enviadas em 1915 e 1916, que verificaram os locais adequados para estabelecer um amplo programa de combate a doenças endêmicas e identificar instituições de ensino médico que pudessem servir de apoio às campanhas por meio da implantação das disciplinas de Higiene e Saúde para formação de quadros. Nessa ocasião, o estado de São Paulo e a Faculdade de Medicina paulista foram considerados aptos a receber o auxílio para a formação dos profissionais da área, em razão dos já existentes serviços de profilaxia e da base intelectual e científica configurada em institutos oficiais de ensino superior e de pesquisa. Desta maneira, foram travados os primeiros acordos e, entre 1918 e 1925, foi introduzido o modelo Rockefeller de educação médica na FMCSP. A partir de 1925 até 1931, deu-se a fase de consolidação do modelo, por meio dos fortes investimentos em instalações, aparelhamento de laboratórios e treinamento de pessoal no exterior, que teriam concedido à faculdade reconhecimento internacional como instituição modelo da Rockefeller.

Na área médica, a política institucional da Fundação Rockefeller estava baseada na disseminação, em escala mundial, da produção científica em saúde e suas decorrentes intervenções técnicas, assim como nos investimentos em formação de profissionais da área, criando um modelo institucional fundado na modernização das práticas médicas e sanitárias, mediante uma articulação entre o fazer técnico e a investigação científica de base laboratorial. Para atingir este objetivo, o modelo de educação médica da Fundação Rockefeller consistia na implantação do limite do número de alunos por turma; da introdução do regime de trabalho de tempo integral para os professores, especialmente para as disciplinas pré-clínicas ligadas à pesquisa laboratorial; da organização dos componentes disciplinares em sistema departamental e da vinculação entre os estudos clínicos e o uso da estrutura de um hospital-escola. Esses termos estavam baseados no Relatório Flexner, documento que se tornou o pilar da modernização da medicina norte-americana e do modelo difundido pela fundação. Nos Estados Unidos, a Fundação Rockefeller implementou esse modelo organizacional e curricular na Universidade 
Johns Hopkins, em sua Escola de Higiene e Saúde Pública e na Escola de Medicina, utilizando aquela instituição como centro de formação de quadros pela concessão de bolsas de estudos para os programas médicos subsidiados pela entidade em todo o mundo (MARINHO, 2013b).

Importante é destacar que as expectativas iniciais e os objetivos existentes nos acordos feitos entre a FMCSP e a Fundação Rockefeller correspondiam mutuamente aos interesses de ambas instituições. Em linhas gerais, o foco central da fundação na terra dos bandeirantes foi a formação de pessoal especializado, indo ao encontro dos interesses e dos anseios de Vieira de Carvalho e de parte da elite médica paulista que vislumbrava a consolidação do projeto de formação médica de “excelência” com base na pesquisa científica. Na análise de Stepan (2011, p.475), a introdução do modelo Rockefeller de saúde pública e ensino médico no caso brasileiro não se deu em uma "tábula rasa”, mas em um contexto em que as elites médicas locais já desenvolviam métodos de pesquisa, campanhas sanitárias e projetos próprios de "excelência” acadêmica.

Em um plano generalizado, para o staff da $I H C$, a melhor forma de criar padrões de uma saúde pública cientificamente fundamentada era prover instituições de saúde pública de alta qualidade ligadas à universidades e escolas de medicina (FARLEY, 2003, p. 203). Para alcançar esse objetivo, a Fundação Rockefeller passou a investir no

\footnotetext{
fomento à pesquisa científica e o apoio ao estabelecimento de grupos permanentes [nos locais contemplados], por meio de financiamento às instalações e equipamentos necessários ao desenvolvimento das atividades, além da concessão de bolsas de estudos e patrocínios, aquisição de publicações, formação de bibliotecas (MARINHO, 2013a, p.14).
}

Esta política institucional encaixava-se perfeitamente nas necessidades da recém-criada faculdade, que buscava soluções para sanar as dificuldades pelas quais passava com a falta de espaço adequado e próprio para as aulas, clínicas e laboratórios; o parco acervo bibliográfico, a instabilidade do quadro docente e a ausência de professores considerados qualificados. Esses entraves teriam levado Arnaldo Vieira de Carvalho a optar pela "solução” Rockefeller, ou seja, pelo apoio institucional privado e estrangeiro, uma vez que o próprio governo paulista não correspondia satisfatoriamente aos pedidos de investimentos do diretor (MOTA, 2005, p. 183-192; p. 200).

Desta maneira, em 1918 instalou-se na FMCSP o Departamento de Higiene sob a direção de Samuel Taylor Darling e apoio de Wilson Smillie, enviados pela fundação para o 
início dos trabalhos. Mediante os auspícios desta instituição, enviou-se para os Estados Unidos Geraldo de Paula Souza e Francisco Borges Vieira para a especialização em pós-graduação na Universidade Johns Hopkins, com o objetivo de retornarem e darem sequência aos trabalhos dos estrangeiros na faculdade paulista. Junto com a implantação do departamento foram criados a função de pesquisador e o regime de tempo integral de trabalho, que seriam posteriormente estendidos às outras cadeiras de disciplinas pré-clínicas como um dos pilares do modelo Rockefeller. Ambos os professores brasileiros receberam bolsas de estudos para o doutoramento na Escola de Higiene e Saúde Pública, onde ficaram ligados entre setembro de 1918 e junho de 1920, quando formaram-se e retornaram ao Brasil para assumir o Departamento de Higiene, justamente no momento de abalo da instituição por conta da morte do Dr. Arnaldo e da instabilidade interna do próprio departamento, com o retorno antecipado de Darling aos Estados Unidos por motivo de doença (CAMPOS, 2013).

Maria Gabriela Marinho (2013b, p.129) e Cristina de Campos (2013, p.51-53) apontam que a morte repentina de Arnaldo Vieira de Carvalho, em junho de 1920, gerou um clima de incertezas quanto ao direcionamento político e institucional da faculdade e deixou em aberto a efetivação dos acordos com a Rockefeller, que estavam ancorados na credibilidade pessoal e profissional do primeiro diretor. Segundo relatos de Geraldo de Paula Souza, parte dos docentes da Faculdade retomaram aproximação com a França por meio de intercâmbio de professores entre a Universidade de Sorbonne e as instituições de ensino superior paulista, reforçando uma prática do próprio governo, tradicionalmente francófilo. Em contrapartida, outro grupo tinha por objetivo manter as relações com a medicina norte-americana, prezando pela manutenção dos acordos com a Fundação Rockefeller. Por conta dessas circunstâncias, ficou ameaçada a concretização da instalação do Instituto de Higiene, assim como a reforma curricular, exigida como ponto chave nos acordos com a fundação.

Este processo de dissensão e oposição correspondia a questões estruturais que perpassavam o campo médico e educacional brasileiro, especificamente, o paulista. Na medicina brasileira, as duas primeiras escolas formadas - na Bahia e no Rio de Janeiro -- foram criadas com base no modelo francês anatomoclínico, que "pressupunha um ensino realizado por meio de trabalho e pesquisa no hospital, especializado na observação técnica do corpo humano”. Esse modelo, implantado na primeira metade do século XIX começava a receber transformações já 
na segunda metade do século, com a introdução de aspectos do modelo médico alemão (KEMP; EDLER, 2004, p.571) $)^{25}$.

As apropriações e transições de modelos de ensino e pesquisa não se deram sem disputas e envolviam arranjos políticos e profissionais dos grupos locais. Nos Estados Unidos, a adoção de aspectos do modelo médico alemão em fins do século XIX fez com que

os médicos práticos, em aliança com aqueles que haviam contribuído para a construção de suas carreiras ancorados nos preceitos e práticas franceses, passaram a resistir aos ataques da nova geração. Os novos adeptos da medicina experimental, impregnados pelo espírito de confiança na renovação e pelo interesse na especialização, procuravam usar o conhecimento laboratorial alemão para apoiar a sua entrada na elite médica (KEMP; EDLER, 2004, p 574).

Foi a partir do início do século XX, imerso neste contexto de "renovação na área médica” que Abraham Flexner desenvolveu sua plataforma de reformas educacionais para estabelecer aspectos do modelo alemão na educação médica e o correlato estilo da Universidade Johns Hopkins para o ensino superior nos EUA, propagando para o mundo o modelo norte-americano de medicina por meio dos trabalhos de filantropia científica da Fundação Rockefeller. Da mesma forma,

a situação no Brasil não era menos complexa do que aquela em que Flexner trabalhava, nos EUA. O ensino médico brasileiro mudava, no começo do século $\mathrm{XX}$, para um padrão indiscutivelmente mais próximo daquele da universidade e do laboratório. Não é difícil portanto encontrar aqui [no Brasil] personagens que, tal como Flexner nos EUA, lutavam por idéias semelhantes. Qualquer análise da mudança brasileira em questão precisa levar em conta o fato de que o Brasil tinha, no começo do século XX e mesmo antes, uma tradição médica complexa e rica que não poderia mudar com facilidade ao capricho das forças de fora (KEMP; EDLER, 2004, p 570).

Em São Paulo, o campo médico no final do século XIX e início do XX representava essa complexidade. Se podemos identificar um grupo em torno da figura de Arnaldo Vieira de Carvalho, defensor da modernização da área médica antes mesmo da efetiva implantação da Faculdade de Medicina na década de 1910 e da adoção do modelo médico norte-americano, há também um grupo que se ligava ao modelo de ensino e pesquisa francês, por adesão a teorias, métodos e estrutura institucional. As diferenças de concepção do saber médico não passava

\footnotetext{
${ }^{25}$ Kemp e Edler (2004) esclarecem que mesmo existindo a prática da pesquisa e da observação no modelo francês, especialmente na tradição pós-revolucionária, fortes queixas às instituições científicas francesas consolidaram-se a partir de 1860, com base nos avanços dos institutos de pesquisa e universidades alemãs, voltados na área médica às pesquisas experimentais e laboratoriais.
} 
somente pela discussão teórica mas, principalmente, pelo comando de instituições médicas e sanitárias pelo rumo de suas políticas de atuação.

Arnaldo Vieira de Carvalho e a faculdade instituída sob seus auspícios acabaram por representar a instalação de uma nova corrente médica em solo paulista, que prezava pela formação científica experimental. Nas palavras de Mota (2014, p.33-34),

em São Paulo, nesse período, as mudanças em torno da medicina ganharam espaço de forma paulatina e truncada, por mais que muitos discursos tentassem dar à Capital um status de modernização e à ciência médica pautada na bacteriologia um espaço amplo de difusão. [...] Com os desdobramentos apontados e somados ao aparecimento de outros atores decisivos, como as investidas, no campo do ensino e da pesquisa na área médica da Fundação Rockefeller, a partir de 1916, configurou-se uma medicina cada vez mais tecnológica no ambiente científico e das práticas de saúde. Foi nesse terreno que Arnaldo Vieira de Carvalho firmou-se como principal expoente da medicina em São Paulo.

Médico formado pela Faculdade de Medicina do Rio de Janeiro na década de 1880, Vieira de Carvalho havia tecido fortes críticas a sua instrução, que caracterizava como retórica, e denunciava a falta de pesquisa experimental no programa de formação. Sendo assim, procurou implementar na estrutura curricular da FMCSP aulas práticas, teóricas e de laboratório, acentuando a formação científica e experimental, mesmo antes dos acordos com a Rockefeller (MARINHO, 2013a, p.111; 2014, p.22-24), demonstrando uma aproximação com a concepção defendida pelo modelo alemão de formação universitária.

A partir das negociações travadas com a Fundação Rockefeller e a consequente implementação de seu modelo de educação médica, o campo médico paulista foi tensionado, assim como as relações com as instâncias de poder ligadas às políticas médico-sanitárias e ao próprio Legislativo e Executivo, criando grupos a favor e contra o paradigma norte-americano. A complexidade do campo médico paulista da década de 1920, momento da crise institucional da faculdade, refletia a própria constituição da ciência médica internacional, pois igualmente na Europa e nos Estados Unidos (a partir da apropriação de elementos do modelo alemão de ciência) os modelos de educação e pesquisa médica estavam em disputa (KEMP, EDLER, 2004).

Como exemplos da existência da tradição científica francesa na área médica paulista, podemos citar o Serviço Sanitário e o Instituto Bacteriológico. Quando criados, tinham como fundamentos a teoria dos miasmas e a teoria microbiana de Pasteur, sendo o instituto instalado por Félix Le Dantec, preparador do Instituto Pasteur em Paris, a pedido do governo do estado 
(CASA OSWALDO CRUZ/ FIOCRUZ, 2016). Seria justamente no Instituto Bacteriológico que, na década de 1920, apareceria forte resistência à introdução dos moldes norte-americanos de medicina no estado de São Paulo, além da existente na própria faculdade por parte de alguns professores. Ao lado da figura de Arnaldo Vieira de Carvalho e da política filantrópica da Fundação Rockefeller formou-se em contrapartida, a “American Legion”26, grupo que disputaria espaço e poder com os defensores da tradição francesa e levaria a cabo a consolidação do modelo Rockefeller de pesquisa e educação médica na Faculdade e em outras instâncias, como no Serviço Sanitário e no Instituto de Higiene.

Para compreender o desenrolar dos acontecimentos após o falecimento de Arnaldo Vieira de Carvalho é imperioso salientar que em 6 de abril de 1919, a Faculdade de Medicina e a Fundação Rockefeller havia travado novos direcionamentos para os investimentos na instituição paulista. Em reunião com Richard Pearce, diretor da Divisão de Educação Médica, Vieira de Carvalho apresentou seu desejo de cooperar com o International Health Board no estabelecimento do departamento de Fisiologia e Farmacologia experimental, que ocorreria da mesma forma da implantação do departamento de Higiene, sendo ainda necessário consultar o governo paulista. Além disso, garantiu um acréscimo no orçamento do departamento de Higiene. Quanto à situação do departamento de Patologia, um dos projetos tratados no primeiro contato entre as instituições, Vieira de Carvalho havia se esquivado a discutir o assunto ${ }^{27}$. De acordo com o registro de Pearce, o diretor evitou tratar a situação, pois não havia candidato disponível para treinamento no Estados Unidos. Da parte da fundação, ficaram à disposição para oferecer uma bolsa de estudos a qualquer momento ${ }^{28}$.

\footnotetext{
${ }^{26}$ A expressão “American Legion” foi encontrada em carta recebida por Ernesto de Souza Campos, em 1923, de seu conterrâneo e colega de turma da Faculdade de Medicina Simeão dos Santos Bomfim, no momento das disputas internas à FMCSP após a morte de Arnaldo Vieira de Carvalho e da partida de Souza Campos para o Instituto Oswaldo Cruz. A carta torna evidente a existência de um grupo defensor das políticas norte-americanas na faculdade, no qual Ernesto de Souza Campos estava incluído. Usamos de empréstimo essa expressão para designar esse grupo, buscando identificar seus componentes por meio do delineamento das ações dos principais personagens relacionados à introdução do modelo Rockefeller na Faculdade de Medicina e dos envolvidos nas tensões desenroladas entre 1920 e 1925, que culminaram na consolidação deste modelo até 1931. Carta de Simeão dos Santos Bomfim a Ernesto de Souza Campos, 7 de dezembro de 1923 [Fundo Ernesto de Souza Campos, Curriculum Vitae, Vol.I].

${ }^{27}$ Extracts from letters by Dr. Richard M. Pearce with reference to the Board's future activities in Brazil. [RAC, Medical Commission to Brazil. "Medical Education in Brazil”, 1.1, 305A, 2, 15, p.41-42]. Os registros dos acordos selados entre a Fundação Rockefeller e a Faculdade de Medicina e Cirurgia encontram-se preservados no Rockefeller Archive Center (RAC), em New York, Estados Unidos, e serão referidos oportunamente na presente pesquisa, especialmente os que dizem respeito à atuação de Emesto de Souza Campos.

${ }^{28}$ Extracts from letters by Dr. Richard M. Pearce with reference to the Board's future activities in Brazil. [RAC, Medical Commission to Brazil. "Medical Education in Brazil”, 1.1, 305A, 2, 15, p.42].A importância da implantação da cadeira de Patologia nos moldes da Rockefeller tem relação com a própria história da
} 
Visivelmente, a Fundação Rockefeller tinha interesse em expandir sua influência na formação médica da Faculdade para além do departamento de Higiene. Entre as cadeiras estava a de Patologia, questão que Arnaldo Vieira de Carvalho negava a desenvolver nos acordos. Até aquele momento, a cadeira de Patologia Geral tinha sido liderada por Alexandre Donati e a de Anatomia Patológica por Walter Haberfeld, que compunham junto a Antonio Carini (cadeira de Microbiologia), Alfonso Bovero (cadeira de Anatomia Experimental e Descritiva), Émilie Brumpt (cadeira de Parasitologia) e Lambert Mayer (cadeira de Fisiologia) um forte grupo de especialistas vindos da Europa $^{29}$ (MARINHO, 2013b, p.112). O entrave para a colocação de docentes enviados pelos norte-americanos nas cadeiras de Patologia era de conhecimento da Fundação e constituía um jogo de forças com os contratos estrangeiros já em andamento. Os planos da Rockefeller passavam pelo envio de um jovem promissor para os Estados Unidos por dois anos de treinamento com um de seus eruditos em patologia e, se o experimento acabasse bem, nomeá-lo em dois ou três anos como chefe do departamento ${ }^{30}$.

Apesar das pressões feitas pelo International Health Board para conseguir o comando do departamento de Patologia na faculdade, o desenrolar dos acontecimentos apontam que isto não foi possível. A “saída” sugerida por Pearce de enviar um jovem pesquisador para treinamento nos Estados Unidos a fim de se preparar para assumir a cadeira também não vingou. Em 7 de janeiro de 1919, em carta de Geraldo de Paula Souza a Richard Pearce o brasileiro sugeria a possibilidade da Rockefeller patrocinar uma cadeira ou departamento na terceira cadeira de clínica médica da faculdade que ainda estava vaga, que poderia ser usada para o desenvolvimento de métodos usados pelos americanos no campo da patologia, especialmente em estudos de doenças tropicais. Com este começo, poderiam enviar aos Estados Unidos um ou dois assistentes do atual departamento de patologia para que no futuro pudessem ter a direção desta seção da escola e ser úteis para as melhorias da Rockefeller na instituição ${ }^{31}$. Embora existisse o empenho de Pearce e Paula Souza em incentivar o envio dos bolsistas para a formação em solo americano, a ideia não foi nutrida por Arnaldo Vieira de Carvalho, ficando o assunto apenas latente, junto com o impasse sobre a situação da cadeira de Patologia. Seria

\footnotetext{
Faculdade de Medicina da Universidade Johns Hopkins e de seus titulares, médicos influentes no staff da Fundação.

${ }^{29}$ Para mais informações sobre a missão italiana na Faculdade de Medicina, consultar Andrade (2017).

${ }^{30}$ Carta de Richard M. Pearce a Wickiliffe Rose, 21 de fevereiro de 1917[ RAC, 305A Sao Paulo Faculty of Medicine -Sao Paulo Historical Records VII, 1.1, 305,4, 24, p.3].

${ }^{31}$ Carta de Geraldo de Paula Souza a Richard M. Pearce, 7 de janeiro de 1919[RAC, 305A Sao Paulo Faculty of Medicine- Sao Paulo Historical Records VII, 1.1, 305, 4, 24, p.8-9].
} 
justamente a referida bolsa de estudos em Patologia oferecida pela Rockefeller que, após o falecimento de Carvalho, viria a ser indicada para Ernesto de Souza Campos, em um contexto de reorganização da direção da faculdade e dos acordos com o novo diretor perante os projetos da Fundação Rockefeller.

\subsubsection{Viagem aos Estados Unidos em tempos de crise institucional}

Como desenvolvimento das negociações seladas entre Pearce e Vieira de Carvalho em 1919, surgiu o segundo acordo assinado entre as instituições, datado do dia de 25 de setembro de 1920. Com a morte de Vieira de Carvalho, principal articulador entre as duas instituições, os acordos entre a Fundação Rockefeller e a Faculdade de Medicina passaram a receber maior influência política da Secretaria do Interior, órgão ao qual a escola estava subordinada, tornando as cláusulas mais exigentes, buscando diminuir o poder decisório da fundação frente ao governo estadual (MARINHO, 2013b, p.127-128). Porém, mesmo com as restrições, a Fundação Rockefeller aproveitou a oportunidade da mudança de direção da Faculdade e avançou na questão da cadeira de Patologia. A pedido de Ovídio Pires de Campos, que assumiu a cadeira de diretor, foi acordada a implantação da área de Anatomia e Histologia Patológicas por

renomados patologistas vindos pela fundação e o envio aos Estados Unidos do bolsista prometido anteriormente.

Conforme apresentou em memorial para o concurso na Faculdade de Medicina no ano de 1923, (CAMPOS, 1923, p.11-14), dois dias após a assinatura do acordo, Souza Campos recebeu o comunicado de que a congregação o classificara como aluno mais distinto da turma de 1918 por suas elevadas notas, razão pela qual recebia como prêmio uma viagem ao exterior. Naquele momento, Souza Campos era sócio titular da Sociedade de Medicina e Cirurgia de São Paulo, trabalhava na faculdade como preparador em Histologia e havia se formado há cerca de um ano. Ernesto de Souza Campos foi o indicado para a vaga de bolsista da Rockefeller deliberada nas negociações em 1919. A assinatura do segundo contrato entre as instituições e sua “premiação" com a viagem ao exterior, ambos na mesma data, além de sua atuação nos Estados Unidos na área de Patologia confirmam esta hipótese. Dado o acirramento do ambiente na faculdade, que se dividiu em dois grupos opostos, os que apoiavam a manutenção da influência norte-americana por meio da Fundação Rockefeller e os que seguiam o movimento 
de aproximação da política governamental com a França, Ovídio Pires de Campos conseguiu, por meio da ratificação da congregação, fundamentar perante o governo paulista a ida de Souza Campos aos Estados Unidos com a indicação do prêmio e assim garantir o recebimento da bolsa da Rockefeller, que já havia sido acordada e somente aguardava a indicação de um candidato pelo diretor. Oficialmente, após a indicação, a bolsa foi concedida por meio de convite feito por Alexandrino de Moraes Pedroso, médico formado nos Estados Unidos, professor da Faculdade e membro da Comissão da Fundação Rockefeller no Brasil juntamente com Carlos Chagas e Vital Brazil.

Não por acaso Souza Campos foi escolhido como bolsista. Àquela altura, já ocupava uma posição bem estabelecida na Faculdade e na Sociedade de Medicina e Cirurgia. Sua trajetória de destaque acadêmico e na gestão do grêmio estudantil da Politécnica e da faculdade médica, seu alinhamento à política institucional da "Casa de Arnaldo" e seus laços estreitos com Ovídio Pires de Campos lhe garantiram a preferência na indicação. Além disso, Souza Campos estava ocupando no momento o cargo de preparador na área de Histologia, uma disciplina afim da cadeira de Patologia e igualmente laboratorial. Os registros indicam que, existindo a possibilidade da bolsa de estudos em um momento de reorganização da administração da faculdade e de incertezas em relação ao andamento dos acordos definidos em 1919 com a Fundação Rockefeller, a indicação de Souza Campos foi mais uma forma de garantir a continuidade das boas relações, especialmente na almejada área de Patologia. Além disso, a ida de um professor da faculdade para os Estados Unidos seria uma forma de contrabalancear a resistência do grupo francófilo à manutenção dos acordos com os norte-americanos. Souza Campos unia o profissionalismo ao trato político e, sendo homem de confiança do diretor Ovídio Pires de Campos, recebeu oportunamente o prêmio de viagem logo após sua indicação à bolsa de estudos, como uma forma de confirmar sua escolha ao intercâmbio e justificar-se perante as pressões internas e o governo estadual. Souza Campos, filho distinto da primeira turma formada pela "Casa de Arnaldo", seria um contato da Faculdade com a Rockefeller nos Estados Unidos, posto estratégico novamente acionado em anos posteriores. Na perspectiva da Fundação, Souza Campos preenchia os requisitos meritocráticos desejados para a formação dos homens que expandiriam as técnicas e os valores científicos em seus locais de origem após o treinamento no país norte-americano.

Antes da partida, Souza Campos acionou sua rede de contatos para a futura inserção no campo acadêmico norte-americano, filiando-se ao grupo dos defensores da manutenção dos 
acordos com a Rockefeller. Em carta endereçada ao Dr. Watson Sellarde, da Escola de Medicina Tropical da Universidade de Harvard, o colega e docente Geraldo de Paula Souza indicava a ida de Souza Campos aos Estados Unidos como bolsista da Rockefeller, pedindo a introdução deste aos patologistas da referida faculdade. Geraldo de Paula Souza escreveu carta semelhante a William Welch, apresentando Souza Campos e pedindo seu acolhimento acadêmico na Escola de Medicina da Universidade Johns Hopkins, referindo-se a sua formação como engenheiro e médico e sua classificação como "um dos melhores alunos" da faculdade paulista $^{32}$.

A história da Universidade Johns Hopkins pode elucidar importantes aspectos a respeito da conformação do modelo médico da Rockefeller e sua utilização como referência de modelo universitário para Souza Campos. A instituição foi aberta em 1876, composta primeiramente por uma Faculdade de Filosofia, pois a planejada Escola de Medicina teve de aguardar a construção do hospital por questões de financiamento, sendo inaugurada somente em 1893. Em discurso, o primeiro reitor da universidade pontuou que, nos Estados Unidos, era muito necessária a formulação de um programa de formação em ciências fundamentais para os estudantes que desejassem ingressar na Medicina, algo que a Universidade Johns Hopkins era capaz de organizar e oferecer antes da abertura de sua escola (JOHNS HOPKINS UNIVERSITY, 1943, p.6).

Como a escola de medicina e o hospital demoraram a serem formados, em 1878, criou-se na Faculdade de Filosofia o curso preliminar de medicina, conhecido como Curso de Química-Biologia, que era feito por todos os alunos de graduação que quisessem entrar na escola de medicina. O curso era composto por aulas de física, química e biologia e estudo de francês e alemão. Por conta desse caminho, a escola teve sua peculiaridade, que seria a ênfase nos estudos e na pesquisa das chamadas disciplinas pré-clínicas. Como havia a pressão pela abertura do curso de Medicina mas ao mesmo tempo, dificuldades financeiras e estruturais de criá-lo, a universidade optou pela criação do curso preparatório e de treinamento para médicos práticos, até a formação do curso profissional (JOHNS HOPKINS UNIVERSITY, 1943).

Em abril de 1884, William H. Welch, graduado em Yale e no Colégio de Físicos e Cirurgiões de Nova Iorque, foi indicado para professor de Patologia, ligado ao curso preliminar. Sob sua cadeira começou a organizar os cursos de bacteriologia e patologia para médicos

\footnotetext{
${ }^{32}$ Carta de Geraldo de Paula Souza ao Dr. William Welch, São Paulo, 16 de outubro de 1920 [Fundo Ernesto de Souza Campos - Curriculum Vitae, Volume I]. Carta de Geraldo de Paula Souza ao Dr. Watson Sellards, São Paulo, 16 de outubro de 1920 [Fundo Ernesto de Souza Campos - Curriculum Vitae, Volume I].
} 
práticos, que eram dados no pequeno Laboratório de Patologia, construído no terreno destinado ao Hospital. Foram nessas condições que seus assistentes, como Simon Flexner, conduziram uma série de investigações que se refletiram em grandes créditos para o hospital e a universidade (JOHNS HOPKINS UNIVERSITY, 1943, p.8).

Outra característica marcante da medicina da Johns Hopkins, que se tornou um pressuposto dos seguidores de seu modelo, é a relação intrínseca entre a faculdade e o hospital, que deveriam estar didática e fisicamente conectados (JOHNS HOPKINS UNIVERSITY, 1943, p.5). Com a abertura do curso de Medicina, sob a direção de William Welch, implantou-se o que ficaria conhecido como modelo de educação médica da Johns Hopkins, seguido por outras instituições no país, especialmente por suas disciplinas pré-clínicas com professores trabalhando em tempo integral (JOHNS HOPKINS UNIVERSITY, 1943, p.11).

Na ocasião dos primeiros acordos da Fundação Rockefeller com a Universidade Johns Hopkins -- que ocorreram por meio de doações do General Education Board para a construção de laboratórios para a Escola de Medicina entre as décadas de 1910 e 1920 e especialmente na criação da Escola de Higiene e Saúde Pública, em 1918, sob seus auspícios e a direção de William Welch -- o modelo de educação médica da universidade já estava fundamentado nos pilares que viriam a ser difundidos pela Rockefeller como necessários para a preparação dos médicos e das instituições contempladas por sua filantropia: o sistema de tempo integral de dedicação nas disciplinas pré-clínicas e a união entre hospital e escola para o ensino das disciplinas clínicas, fazendo os estudantes parte integral da equipe do Hospital durante a formação. Essa base convergiu com os princípios defendidos por Abraham Flexner, irmão de Simon Flexner, em seu plano de reformas para a educação médica norte-americana na década de 1910, à frente do General Education Board da Fundação Rockefeller.

Enquanto estudava na Alemanha, Abraham Flexner escreveu suas críticas ao sistema educacional superior americano, que lhe renderam a indicação por Henry Pritchett, presidente da Fundação Carnegie, para estudar a situação das escolas médicas nos Estados Unidos e Canadá. Deste estudo de campo resultou Medical Education in the United States and Canada, relatório no qual alegava que os principais pontos críticos das instituições eram a falta de formação científica e o enraizado sistema de educação voltado para o lucro, que teria resultado em um grande número de médicos credenciados, mas não qualificados. Após o sucesso do relatório, Abraham Flexner foi convidado a ser secretário da General Education Board em 
1912, e sob sua liderança a junta e a Fundação Rockefeller ingressaram em um importante programa de reforma de educação médica (ROCKEFELLER ARCHIVE CENTER, 2017).

Segundo Farley (2003, p.203-204), apesar de Wickliffe Rose, primeiro diretor da International Health Commission, desejar dar suporte às pequenas escolas orientadas ao treinamento para as necessidades práticas dos departamentos de saúde pública, a Junta de Educação Geral, responsável pelo empreendimento, optou pelo modelo médico alemão voltado à pesquisa, concordando com Welch, defensor da criação de escolas que cultivassem o avanço da ciência da higiene e não objetivassem suprir imediatamente as necessidades do serviço de saúde pública. Assim, a Junta decidiu por favorecer a formação de escolas de higiene, baseada na pesquisa biomédica em bacteriologia e na teoria dos germes, escolhendo a escola de medicina da Universidade Johns Hopkins, em Baltimore, como local para seu modelo de escola de higiene e saúde pública.

A história da Universidade Johns Hopkins e sua tomada como posto de formação médica para os projetos da Fundação Rockefeller entraram em cooperação por meio da atuação de William Welch, figura chave no processo. Welch, que unia a autoridade de pesquisador em Patologia e Bacteriologia e de diretor da Escola de Medicina (1893-1898), foi convidado a organizar e liderar a Escola de Higiene e Saúde Pública no ano de 1917, tornando-se professor de Bacteriologia e Imunologia e primeiro diretor da unidade (JOHNS HOPKINS UNIVERSITY, 1943). Na Escola de Medicina foi sucedido por William G. MacCallum, membro da primeira turma de graduação da escola. Foi nesse contexto que Ernesto de Souza Campos embarcou para os Estados Unidos, para especializar-se na cadeira de Patologia, considerada como a “origem” das pesquisas laboratoriais da instituição antes mesmo da criação da Escola de Medicina. Não foi, portanto, sem propósito que a Fundação Rockefeller, ao escolher a Faculdade de Medicina e Cirurgia de São Paulo como centro de formação de seu modelo no Brasil recomendou a instalação dos laboratórios de Patologia e Higiene, indicação que foi aceita inicialmente por Vieira de Carvalho e reiterada na gestão de Pires de Campos, constituindo o cerne dos trabalhos da Fundação até 1925.

Enquanto isso, na Faculdade de Medicina e Cirurgia de São Paulo, como era de costume entre os médicos, foi oferecido um chá em homenagem a Souza Campos na véspera de sua partida para os Estados Unidos, evento que foi noticiado na imprensa por diferentes jornais. Estavam entre os aderidos o diretor Ovídio Pires de Campos, Alexandrino de Moraes Pedroso, Alfonso Bovero, Oscar Freire, Cantídio de Moura Campos, Adolfo Lindemberg, Alessandro 
Donati, Celestino Bourroul, Pedro Dias da Silva, Raul Vieira de Carvalho, Zeferino do Amaral, representante do “Centro Acadêmico Oswaldo Cruz”, entre outros ${ }^{33}$.

O fellow chegou aos Estados Unidos em 4 de novembro de 1920 e foi para Baltimore, em Maryland, onde ingressou no Departamento de Patologia da Johns Hopkins Medical School no dia 12 de novembro, lá permanecendo até 18 de novembro de 1922. Durante esse período, foi convidado a fazer parte do staff do professor MacCallum, dando aulas práticas e teóricas. “Admitido como assistente foi, mais tarde, promovido a 'instructor in Pathology', posto superior na escola dos que se dedicam à carreira do professorado”, publicando durante esse período trabalhos pela universidade norte-americana (CAMPOS, 1923, p.15-17).

Da estada de Souza Campos nos Estados Unidos destacamos sua vivência em uma universidade e faculdade de renomado status internacional na área médica e sua relação estreita com os preceitos defendidos e difundidos pela Fundação Rockefeller para a pesquisa e o ensino médico. Em seu arquivo pessoal, poucos são os registros da permanência em Baltimore. Alguns dos documentos preservados são fotos com legendas que apresentam o grupo de professores de seu convívio, o prédio antigo do Departamento de Anatomia Patológica, seu laboratório e sua atividade de pesquisa experimental. Na Johns Hopkins, Souza Campos trabalhou com MacCallum; com o professor Ben Jones, da cadeira de Bacteriologia; com o Dr. Cash, assistente e posteriormente professor de Patologia na Universidade de Pequim; com o Dr. Berstrand, da Universidade de Christiania, na Noruega; com o professor Rich, instrutor do Departamento; com o professor do Instituto Oswaldo Cruz Olympio Fonseca Filho, que em 1920 estava de passagem em Baltimore, e com o com Dr. Firket, assistente do Departamento e posteriormente professor de Anatomia Patológica na Universidade de Liége, na Bélgica. Durante sua carreira na Faculdade de Medicina em São Paulo, Souza Campos manteve contato com colegas de estágio, por meio de troca de correspondências e materiais de pesquisa, fato que contribuiu para a circulação internacional de suas pesquisas ${ }^{34}$.

Outro ponto essencial é que entre os escassos registros da viagem, Souza Campos preservou fotografias do trabalho em laboratório, o que indica a importância que dispensou à questão. O Departamento de Patologia da Escola de Medicina da Johns Hopkins constituiu base importante da renovação da medicina norte-americana, ao lado dos departamentos de Higiene e

\footnotetext{
${ }^{33}$ CHÁ em homenagem a Ernesto de Souza Campos por sua partida aos Estados Unidos [Fundo Ernesto de Souza Campos - Curriculum Vitae - Volume I].

${ }^{34}$ No acervo pessoal de Souza Campos estão preservadas diversas cartas de professores de outras universidades em que esteve em contato durante a carreira, relatando a troca de artigos e livros entre os pares.
} 
Saúde Pública. Sua formação em pesquisa laboratorial em solo norte-americano o incorporava ao movimento de instituição do modelo de educação médica da Rockefeller, difundido e implantado em São Paulo e pelo mundo, que tinha como pilar a pesquisa experimental para o subsídio da clínica. Por esta “marca” acadêmica, de pesquisador laboratorial, Souza Campos iniciava seus contatos com a Fundação Rockefeller, para mais tarde destacar-se como conhecedor da questão, especialmente na fase de consolidação dos acordos entre a Fundação e a Faculdade, com a construção da sede da instituição.

\subsubsection{Disputas e "desencaixe” no retorno a São Paulo}

Enquanto Ernesto de Souza Campos cumpria estágio na Johns Hopkins, os embaraços nas negociações entre o governo estadual e a Fundação Rockefeller continuaram, refletindo as disputas internas à Faculdade de Medicina. Na tentativa de convencer a instituição norte-americana a manter o apoio à faculdade e ao laboratório de Higiene, Dr. Smillie, junto a Geraldo de Paula Souza fazia esforços para avaliar e apontar soluções. Na defesa do modelo norte-americano de saúde pública, Paula Souza escrevia a Wickliffe Rose explicando as causas das conflitos instaurados pela ofensiva dos defensores do modelo francês. Para o médico, laboratórios de numerosas áreas foram abertos para preencher diversos nichos, tanto no Rio quanto em São Paulo, refletindo a influência francesa nas pesquisas em Microbiologia. Tal situação teria levado ao que chamou de “calamidade pública dos laboratórios”, fator que era agravado se somado às circunstâncias das faculdades de medicina do Rio e da Bahia, “afundadas em profunda inércia” e comandadas por médicos que trabalhavam em regime parcial e que dedicavam o tempo restante às clínicas particulares, não à pesquisa. Sendo assim, se a Rockefeller mantivesse seus investimentos e orientação, a Faculdade em São Paulo poderia gradualmente suplantar as tradicionais escolas e exercer importante influência sobre o sistema médico educacional no Brasil. Nas palavras de Smillie, existia na faculdade paulista um pequeno mas forte grupo, que tinha a concepção clara do que uma boa escola médica deveria ser e com que os representantes da Rockefeller poderiam contar, mesmo diante das resistências dos adeptos do modelo francês (apud FARLEY, 2003, p.204-206).

Uma dessas oposições era representada pelo Dr. João Alves de Lima, professor de Clínica Cirúrgica e cunhado do governador Washington Luís. Alves de Lima tinha se formado 
na Faculdade de Medicina de Paris em 1897, e era adepto convicto da medicina e cultura francesa (ACADEMIA DE MEDICINA DE SÃO PAULO, 2017). Para Smillie, Alves de Lima era quem verdadeiramente detinha o poder na faculdade no ano de 1921, portanto, era com ele que os norte-americanos deveriam se preocupar, não com o diretor Edmundo Xavier. Era sabido pelo americano que Alves de Lima não simpatizava com Geraldo de Paula Souza e Alexandrino de Moraes Pedroso, americanófilos, e não confiava nos motivos do International Health Board em apoiar a faculdade. Por essa razão, Wilson Smillie recomendou cautela, sugerindo a seus superiores encontrar maneiras de o doutor respeitar e confiar na política da Rockefeller. Desta forma, Alves de Lima foi convidado a receber um título honorário da American College of Surgeons, nos Estados Unidos, ocasião utilizada para tentar uma aproximação por parte dos americanos, apresentando ao cirurgião os benefícios que o país teria a oferecer ao Brasil (FARLEY, 2003, p.206). A estratégia teria rendido frutos, pois Alves de Lima compôs o comitê de professores da faculdade que comandou o processo de reorganização do currículo com base nas recomendações da Rockefeller, de cujo projeto Washington Luiz expressou sua apreciação ${ }^{35}$.

Em 1922, Fred Russell e Richard Pearce visitaram São Paulo e com a indicação do novo diretor da Faculdade, Celestino Bourroul, considerado mais "progressista”, as reformas começaram a desenrolar. Paula Souza assumiu a direção do Instituto de Higiene da faculdade após a volta de Smillie aos Estados Unidos e o posto de diretor do Serviço Sanitário do estado. Concentrando os dois cargos, propôs à Rockefeller a execução do plano de amalgamar sob o Departamento de Higiene os institutos sanitários do Estado -- Vacinogênico, Bacteriológico e Butantã, tornando assim o Instituto de Higiene de São Paulo independente da faculdade e ligado diretamente à Secretaria do Interior. O plano não teria agradado Russell, pois de acordo com o antigo staff do International Health Board, estava inclinado a defender que o Instituto de Higiene estivesse ligado à escola médica, como no modelo da Johns Hopkins, para evitar sua submissão aos caprichos dos governos (apud FARLEY, 2003, p.207).

O projeto de Paula Souza desagradava também o Dr. José Pedro de Carvalho Lima, que entre 1922 e 1923, foi diretor do Instituto Bacteriológico. Em contra-ataque à proposta, Carvalho Lima enviou um relatório à junta da Rockefeller e à Secretaria do Interior, justificando sua oposição com base nos trabalhos já feitos e bem sucedidos do instituto sob sua liderança.

\footnotetext{
${ }^{35}$ RAC, Medical Commission to Brazil. “Medical Education in Brazil”, 1.1, 305A, 2, 15A, p.3-4.
} 
Além de defender a autonomia administrativa e científica do órgão e justificar que a implantação da organização americana perturbaria os serviços já instituídos, Carvalho Lima teria entrado em desafeto com os americanos por conta de uma palestra de Lewis Hackett, na Escola Médica de Harvard. Nesta oportunidade, Hackett teria insultado e ridicularizado os médicos brasileiros, comparando-os a “jecas” e ressaltando a proeminência da Rockefeller como promotora do melhoramentos científicos no Brasil (FARLEY, 2003, p.208). Apesar dos percalços, sob a influência política e institucional de Paula Souza o projeto do Instituto de Higiene de São Paulo foi aceito pelo congresso e instituído em 1925.

Ao retornar a São Paulo no final do ano de 1922, a carreira de Souza Campos encontrava-se em uma encruzilhada de possibilidades e de pouca certeza. Ao mesmo tempo que alavancava seu status acadêmico para fellow da Fundação Rockefeller, reconhecido pela nova formação em pesquisa experimental, a situação interna da Faculdade de Medicina e Cirurgia colocava empecilhos para seu estabelecimento definitivo, como era previsto. Por conta do desenrolar do acordo com a Rockefeller e da indicação do pesquisador Oskar Klotz para a cadeira de Anatomia e Histologia Patológicas, Souza Campos retornou ao cargo de preparador na cadeira de Histologia, não o exercendo diretamente na cadeira de Patologia, área de seu estágio. Oskar Klotz, eminente patologista e professor da Universidade de Pittsburg havia sido indicado por William Welch, Simon Flexner e MacCallum, professores da Johns Hopkins e membros conselheiros da Fundação Rockefeller, para ocupar pelo período de dois anos a cadeira na Faculdade de Medicina e Cirurgia de São Paulo naquele momento estratégico dos acordos. Chegando a São Paulo em 1921, Klotz tornou-se o principal intermediador entre a fundação e a Faculdade, pois Darling já havia retornado para os Estados Unidos em 1920, e Smillie, que retornaria aos Estados Unidos em breve, concentrava-se em trabalhos de pesquisa de verminoses no interior. Klotz ficou em São Paulo de fevereiro de 1921 a fevereiro de 1923, sendo substituído por Robert Archibald Lambert, último professor da delegação Rockefeller na faculdade. No período em que Klotz esteve em São Paulo, foi o responsável pela assinatura e intermediação de acordos importantes, como a manutenção do Departamento de Higiene, renomeado Instituto de Higiene como órgão anexo à Faculdade e a efetiva implementação do modelo Rockefeller após o envio da Recomendação à Faculdade de Medicina de São Paulo no tocante aos meios de melhorar a Educação Médica, elaborada por Richard Pearce a pedido da direção da instituição paulista. Este documento foi a base para a oficialização legal da reforma curricular da escola, entre 1924 e 1925 (MARINHO, 2013b, p.132-137). 
Do ponto de vista da Fundação Rockefeller, a efetivação do modelo de educação médica na Faculdade de Medicina era a principal questão a partir do ano de 1922, ação que estava concentrada nas interlocuções entre Pearce, seus representantes Klotz e Lambert e a direção da faculdade, que ainda permanecia instável, com uma “troca de cadeiras” constante ${ }^{36}$.

Por conta deste cenário, em 1922 a fundação necessitou enviar um novo representante de peso para dar continuidade aos trabalhos de intermediação iniciados por Darling e, em consequência, o bom posicionamento de Ernesto de Souza Campos ficou comprometido. Como resultado da situação indefinida, deu-se a crescente proeminência de Geraldo de Paula Souza como "executor" dos projetos do Instituto de Higiene e o afastamento de Souza Campos da faculdade no ano seguinte, em busca de melhor colocação profissional. Este desencaixe institucional vivenciado por Souza Campos ficou evidente no processo do concurso que participou em 1923, concorrendo à vaga com Ludgero Cunha Motta, assistente de Oscar Klotz em regime parcial desde janeiro de $1922^{37}$.

O próprio diretor da Divisão de Educação Médica, Alan Gregg, em carta dirigida a Klotz reconheceu a situação desconfortável de Souza Campos no concurso para o preenchimento da cadeira de professor substituto na seção IV Histologia, Microbiologia, Anatomia e Histologia Patológica, classificando a posição de Souza Campos como infeliz ${ }^{38}$. Com a volta eminente de Klotz aos Estados Unidos e a vinda do novo representante da Rockefeller, Alan Gregg reforça a posição de distanciamento perante o resultado do concurso, indicando ao recém contratado professor Robert Archibald Lambert, manter-se em posição de neutralidade ${ }^{39}$. Os norte-americanos viam os processos de concursos na faculdade com certa ressalva, pois estes geravam um clima de acirramento na instituição, algo que não era salutar aos planos da Rockefeller, além de identificá-lo ao sistema de concurso das escolas francesas, em detrimento do sistema norte-americano de indicação e contrato ${ }^{40}$. Com o desenrolar do

\footnotetext{
${ }^{36}$ De julho de 1920 até maio de 1924, quando conseguiu-se uma relativa estabilidade na direção da Faculdade de Medicina com a indicação do médico Pedro Dias da Silva para diretor, quatro professores revezaram-se na cadeira: o vice de Arnaldo Ovídio Pires de Campos, no período de 16 de julho de 1920 a 14 de janeiro de 1921; Edmundo Xavier, de 21 de fevereiro de 1921 a 21 de fevereiro de 1922; Celestino Bourroul, de 2 de março de 1922 a 11 de dezembro de 1922 e Adolpho Carlos Lindenberg, de 15 de dezembro de 1922 a 30 de abril de 1924 ( MARINHO, 2013b, p. 130).

${ }^{37}$ RAC, Medical Commission to Brazil. “Medical Education in Brazil”, 1.1, 305A, 2, 15A, p.2.

${ }^{38}$ Carta de Alan Gregg a Oskar Klotz, 17 de janeiro de 1923 [RAC, 305A Sao Paulo Faculty of Medicine- Sao Paulo Historical Records VIII, 1.1, 305, 4, 24 A, p.7].

${ }^{39}$ Carta de Alan Gregg a Robert A. Lambert, 4 de abril de 1923 [RAC, 305A Sao Paulo Faculty of MedicineSao Paulo Historical Records VIII, 1.1, 305, 4, 24 A, p.33].

${ }^{40}$ Carta de Oskar Klotz a Richard M. Pearce, 17 de janeiro de 1923 [RAC, 305A Sao Paulo Faculty of

Medicine- Sao Paulo Historical Records VIII, 1.1, 305, 4, 24 A, p.9-10].
} 
concurso, em maio de 1923, apesar da orientação de imparcialidade dada por Alan Gregg, o professor Lambert discorreu de forma eloquente sobre o assunto com George E. Vincent, presidente da Fundação Rockefeller. Para Lambert, depois de conversar com Souza Campos sobre sua experiência no concurso, estava inclinado fortemente contra o sistema, dada a sua crueldade em estender-se por um período de duas a três semanas de avaliações. No entanto, ponderou que os concursos eram defendidos pelos brasileiros como forma de evitar indicações de favorecimento político ${ }^{41}$.

Durante esse processo, Souza Campos tinha voltado a frequentar as reuniões da Sociedade de Medicina e Cirurgia e utilizou esse local de exposição e reafirmação no campo médico paulista para apresentar seus trabalhos de pesquisa experimental, buscando reconhecimento entre os pares. No memorial preparado para o concurso, além de apresentar seu histórico de formação acadêmica, Souza Campos esforçou-se em expor os contatos com importantes estudiosos em patologia nos Estados Unidos, incluindo uma lista de trabalhos feitos em pesquisa experimental e de anatomia no hospital-escola da Universidade Johns Hopkins. Chegou a afirmar que, antes mesmo de retornar ao Brasil, teria sido

convidado pelo professor MacCallum para permanecer no Departamento de Patologia pelo menos, durante mais um ou dois anos,[mas] declinou do honroso convite porque a sua comissão deveria durar dois anos, de acordo com o que fora estabelecido pela Diretoria da Faculdade de Medicina de S. Paulo. Foi ainda convidado para um dos lugares de patologista residente do Johns Hopkins Hospital (CAMPOS, 1923, p.21).

Não obstante o empenho em demonstrar sua superioridade para o cargo, que passava pela exposição da vivência na Johns Hopkins e pelo convite para permanecer nos Estados Unidos, a vaga do concurso foi preenchida pelo médico Ludgero da Cunha Motta. Naquele momento a influência da Rockefeller não era unânime entre os professores de modo que o

\footnotetext{
${ }^{41}$ Carta de Robert A. Lambert a George E. Vincent, 26 de maio de 1923 [RAC, 305A Sao Paulo Faculty of Medicine- Sao Paulo Historical Records VIII, 1.1, 305, 4, 24 A, p.60-61]. Robert Lambert referia-se às cartas de recomendação feitas por Richard Pearce em 1922, nas quais fazia sugestões para a reforma da escola. Nelas, Pearce acreditava ser suficiente a escolha do professor por um comitê de titulares que iria avaliar a competência do candidato de acordo com seu histórico curricular (MARINHO, 2013b, p. 142). As sugestões de modificações foram encaminhadas ao comitê da faculdade responsável pela reforma. O desenrolar desta questão na nova regulamentação da faculdade necessitaria um trabalho detalhado que fugiria de nosso objetivo no momento. No entanto, fica indicada pela documentação subsequente que Lambert debruçou-se sobre o assunto durante sua estada em São Paulo e em conversa com Pedro Dias da Silva, em julho de 1924, ambos acordaram que o concurso não era um sistema adequado mas que, por resistência dos docentes, deveria ser mantido com algumas modificações que assegurassem maior eficiência para escolher o candidato de acordo com as necessidades da cadeira. Carta de Robert Lambert a Richard Pearce, 5 de julho de 1924. [RAC, 305A Sao Paulo Faculty of Medicine- Sao Paulo Historical Records VIII, 1.1, 305, 4, 24 A, p.165].
} 
estágio nos Estados Unidos não lhe garantiu a melhor posição, pois o controle do processo era dos professores catedráticos brasileiros. A decepção de Souza Campos foi profunda. Imediatamente, Souza Campos pediu demissão de seu cargo de preparador em Histologia e passou a considerar sua ida para o Instituto Oswaldo Cruz, no Rio de Janeiro. Como forma de amenizar a situação, o diretor Adolfo Lindenberg deixou o pedido de demissão em aberto, na esperança de que ele mudasse de ideia. Robert Lambert lamentava sua situação, e em conversa com Souza Campos tentou convencê-lo a não agir de forma precipitada. Souza Campos estava de partida para a fazenda, para descansar por um ou dois meses. Segundo o relato de Lambert, o diretor Lindenberg expressou seu profundo pesar sobre a decisão de Souza Campos, expressando-se favorável a este pelo treinamento nos Estados Unidos, mas ressaltou que a questão do “emaranhamento com os oposicionistas" deveria ser levado em conta para compreender a circunstância ${ }^{42}$.

O concurso do qual Souza Campos participou foi representativo das tensões internas no campo médico paulista, especialmente na Faculdade de Medicina e Cirurgia. Em carta a Klotz, Lambert expõe sua visão de que o resultado, de onze votos a favor de Cunha Motta contra sete a favor de Souza Campos fora efeito de pura expressão de afiliações políticas, já que ambos os candidatos haviam mostrado competência sobre o assunto e que existia indecisão sobre os resultados $^{43}$. O representante da Rockefeller também demonstrava preocupação com o futuro da cadeira após o término do seu contrato. Com o fim do concurso, Cunha Motta foi orientado a escolher a cadeira de Patologia, já que o concurso era válido para toda a seção, evitando que Carmo Lordy, catedrático de Bacteriologia e considerado do grupo opositor, a assumisse ao retornar de seus estudos na Alemanha, na área de Patologia. O diretor Lindenberg acreditava que Lordy, mesmo desejando a cadeira de Patologia não aceitaria o sistema de tempo integral proposto, o que era imprescindível para o sucessor de Lambert, conforme os planos da Fundação. Em acordo entre o diretor e Cunha Motta ficou decidido que este permaneceria na cadeira de Bacteriologia até a volta de Lordy, quando assumiria full-time a cadeira de Patologia, até que em ocasião oportuna pudesse seguir para treinamento nos Estados Unidos ${ }^{44}$. Estava, dessa maneira, planejada a continuidade do sistema Rockefeller na fundamental cadeira de

\footnotetext{
${ }^{42}$ Carta de Robert A. Lambert a Richard M. Pearce, 12 de junho de 1923.[ RAC, 305A Sao Paulo Faculty of Medicine- Sao Paulo Historical Records VIII, 1.1, 305, 4, 24 A, p.79; p.81].

${ }^{43}$ Carta de Robert A. Lambert a Richard M. Pearce, 25 de junho de 1923 [RAC, 305A Sao Paulo Faculty of Medicine- Sao Paulo Historical Records VIII, 1.1, 305, 4, 24 A, p.93].

${ }^{44}$ Carta de Robert. A. Lambert a Oskar Klotz, 25 de junho de 1923 [RAC, 305A Sao Paulo Faculty of Medicine- Sao Paulo Historical Records VIII, 1.1, 305, 4, 24 A, p.90-91].
} 
Patologia, que, ao lado do Instituto de Higiene, eram estratégicos para o seguimento do modelo da Johns Hopkins na Faculdade de Medicina e Cirurgia de São Paulo.

Em julho de 1923, Souza Campos tentou uma nova colocação na carreira em São Paulo, pedindo auxílio a Geraldo de Paula Souza, diretor geral do Serviço Sanitário do estado, para ser indicado ao cargo de sua especialidade nesse órgão. No entanto, sua tentativa não encontrou êxito. Em carta, Paula Souza reconhece a elegibilidade de Souza Campos para o cargo no Serviço Sanitário, mas acaba reportando a impossibilidade às questões de organização técnica interna, orçamento e negociação política, possivelmente o aspecto crucial. Restaria apenas uma oportunidade de assumir o cargo comissionado neste órgão, através da Faculdade de Medicina, ou de aguardar oportunamente um cargo que viria a ser conversado com o Secretário do Interior para o Instituto Bacteriológico, acordo que possivelmente Souza Campos descartou dada a situação de indisposição na faculdade ${ }^{45}$.

Em 30 de outubro, Souza Campos recebeu carta de Olympio da Fonseca, à época professor em Micologia no Instituto Oswaldo Cruz e antigo colega durante o estágio em Baltimore, convidando-o para conversar com Carlos Chagas a respeito de uma possível vaga no instituto:

Em conversa a seu respeito com o Dr. Chagas, fui autorizado a escrever a V. perguntando se lhe agradaria fazer parte do pessoal do Instituto Oswaldo Cruz, onde poderia V. se dedicar a estudos de hematologia, ali instalando para isso laboratório especial, ou a estudos de anatomia patológica. Devo dizer também que espera-se para breve uma reforma e que é possível que esta acarrete a efetivação do pessoal contratado. Apesar de seus numerosos defeitos, muito exagerados pelos seus detratores, estou certo que embora seja eu suspeito para dizê-lo, que constitui uma boa organização para pesquisa científica, a melhor que possuímos. Por isso mesmo, faltando aqui quem cuide de hematologia, viria V. preencher um claro evidente, além de nos dar o prazer da amável companhia ${ }^{46}$.

Souza Campos havia conhecido Carlos Chagas durante sua estada nos Estados Unidos, e àquela altura já considerava uma colocação no Instituto Oswaldo Cruz, igualmente financiado

\footnotetext{
${ }^{45}$ Carta de Geraldo de Paula Souza a Ernesto de Souza Campos [Fundo Ernesto de Souza Campos, Curriculum Vitae, Vol. I].

${ }^{46}$ Carta de Olympio da Fonseca a Ernesto de Souza Campos, 30 de outubro de 1923 [Fundo Ernesto de Souza Campos, Curriculum Vitae, Vol.I]
} 
pela Fundação Rockefeller, por provável aconselhamento de Lambert e sugestão de Pearce, que garantiu a busca de Carlos Chagas por um pesquisador do perfil de Souza Campos ${ }^{47}$.

Para Stepan (2011, p. 478), se o foco da Fundação Rockefeller na Faculdade de Medicina de São Paulo foi criar um centro de treinamento de excelência, a capital federal constituía uma oportunidade de inserção que não poderia ser ignorada, o que tornava o Rio de Janeiro interessante para que suas políticas pudessem influenciar em nível nacional. Além disso, foi considerada a proeminência do Instituto Oswaldo Cruz, antes liderado pelo internacionalmente renomado pesquisador Oswaldo Cruz. Por conta desses fatores, o escritório central do International Health Board para a América Latina ficou instalado no Rio entre 1917 e 1942. Na década de 1920, o principal intermediário entre a Fundação Rockefeller, o Instituto Oswaldo Cruz e o governo federal era Carlos Chagas. Chagas foi nomeado diretor do Departamento Nacional de Saúde Pública em 1920, cargo que somou ao da diretoria do Instituto Oswaldo Cruz, que exercia desde 1917, após a morte do patrono (KROPF, 2011). Conforme apontou Stepan (2011, p.481), nesse período Carlos Chagas encontrava-se em "forte posição para negociar os termos da cooperação” do Brasil com a Fundação Rockefeller.

Com os ventos soprando a seu favor em terras cariocas, Souza Campos acabou por aceitar o convite de Carlos Chagas e mudou-se para o Rio de Janeiro, onde permaneceu como assistente adjunto na seção de Hematologia do Instituto Oswaldo Cruz até o ano de 1925. Porém, antes de sua partida, seus aliados não deixaram a decisão passar despercebida, aproveitando a oportunidade para enaltecer o feito de Souza Campos e superar as tramas que envolveram sua escolha de mudança. Em carta, o amigo e colega de profissão, Dr. Simeão dos Santos Bomfim, o congratulava:

\section{Meu caro Souza Campos}

A boa nova que o "Estado de S. Paulo" de hoje coloca nas suas colunas de honra constitui para mim motivo de intenso júbilo: Carlos Chagas, após ter conhecido V. em Baltimore, no Laboratório de Mac. Callum, reitera o convite para trabalhar no Instituto Oswaldo Cruz.

Era muito mais consumado para V. ter ficado na Johns Hopkins University, onde MacCallum, conhecedor de suas excelentes qualidades de investigador e de seu sólido preparo já o prestigiara grandemente, confiando-lhe cargos de responsabilidade que V. exerceu em todo brilhantismo ou então ter interrompido sua viagem quando, juntos, pisamos terras brasileiras e satisfazer o primeiro convite do cientista que, com toda competência, dirige Manguinhos.

\footnotetext{
${ }^{47}$ Carta de Richard M. Pearce a Robert A. Lambert, 27 de junho de 1923 [RAC, 305A Sao Paulo Faculty of Medicine- Sao Paulo Historical Records VIII, 1.1, 305, 4, 24 A, p.97].
} 
Mas, compromissos anteriores e o amor que V. dedica à nossa Faculdade te conduziram a S. Paulo, onde V., provou o cálice da amargura num momento em que as paixões empolgavam a alma de seus antigos mestres, asfixiando o que há de mais nobre, mais divino e mais vital sobre a terra - a Justiça.

O armistício celebrado ontem não me parece que tenha longa duração. O que é de se lastimar profundamente porque a Escola construída com tanto carinho e firmeza por Arnaldo V. de Carvalho muito sofrerá com essas dissenções.

Pois bem, meu boníssimo amigo e companheiro dedicado do "American Legion”, faço a mais ardentes votos para que mantenha sempre vivo dentro do peito, o fogo sagrado do Ideal, que venho admirando desde a fundação da nossa Escola, porque dele depende o progresso da Ciência, a grandeza da Pátria e o bem da Humanidade. ${ }^{48}$

O apoio a Souza Campos foi manifesto publicamente no almoço oferecido por colegas e amigos em homenagem à sua partida, no Parque Trianon. Em resposta ao tributo, Souza Campos discursou sobre as Ciências e as Artes, indicando o espírito que guiava sua nova jornada:

No que de mais perto nos toca, lembremos que as complicações crescentes e as múltiplas exigências dos problemas sociais demandam um preparo científico correlato. Temos ainda um problema social de máxima importância. Nosso povo é ainda amorfo, indefinido, vago. É preciso formá-lo e mais ainda educá-lo. Para isto é necessário organizar e estimular a classe dos professores e cientistas pelo método da seleção gradual e lenta que é o único que dá resultados seguros. Os cristais puríssimos obtêm-se por lenta cristalização. Neste sentido é que mais avulta a contribuição da escola de Manguinhos, escola de seleção e de ciência pura. Por isso aceitei o convite de Carlos Chagas [...]. Para lá vou ungido de fé e confiante no futuro ${ }^{49}$.

Embora confiasse ter encontrado seu caminho de agente “civilizador" no campo das ciências médicas no Instituto Oswaldo Cruz, Souza Campos viu seu destino transformar-se novamente em 1925, quando, por mudanças de ordem política, as portas da Faculdade de Medicina lhe ficaram novamente abertas.

\subsection{CONSTRUIR É MATERIALIZAR O MODELO}

\footnotetext{
${ }^{48}$ Carta de Simeão dos Santos Bomfim a Ernesto de Souza Campos, 7 de dezembro de 1923 [Fundo Ernesto de Souza Campos, Curriculum Vitae, Vol.I].

${ }^{49}$ Discurso de Ernesto de Souza Campos na ocasião de almoço em sua homenagem [1923?] [Fundo Ernesto de Souza Campos, Curriculum Vitae, Vol. I].
} 
No dia 1 de maio de 1924, assumiu o novo presidente do estado de São Paulo Carlos de Campos. Em consequência, o cargo de diretor da Faculdade de Medicina foi revisto, assumindo em lugar de Adolpho Lindenberg o médico Pedro Dias da Silva, a 14 de maio. Conforme depoimento de Souza Campos (1954, p.362), Carlos de Campos convidou Pedro Dias para o cargo de diretor por ser-lhe homem de confiança (Pedro Dias da Silva era seu médico particular) e por ser profissional estranho ao corpo docente da faculdade, então dividida em duas facções hostis. Souza Campos e Pedro Dias eram amigos de longa data, desde o trabalho na Santa Casa de Misericórdia sob a orientação de Ovídio Pires de Campos. Em conversa, Souza Campos teria aconselhado Pedro Dias sobre a situação da Faculdade de Medicina e as negociações com a Fundação Rockefeller:

Perguntou-nos Pedro Dias qual a nossa opinião sobre sua possível nomeação. Afirmamos que seria interessante sua aceitação. Gozando de absoluta confiança da administração pública, poderia reatar as negociações com a Fundação Rockefeller e prestar, assim imenso serviço à educação médica paulista. Pedro Dias não estava informado do assunto a não ser muito pela rama. Explicamos miudamente a questão, por duas longas horas, abrigados em uma casa de café, existente nas proximidades. Perguntou-nos se poderíamos auxiliá-los no provável empreendimento. Garantimos nossa cooperação, embora estivéssemos trabalhando na capital da República. No Rio de Janeiro chegou-nos a notícia da nomeação do Dr. Pedro Dias (CAMPOS, 1954, p.362-363).

De acordo com Marinho (2013b, p.137-149), o processo de formulação dos projetos de reorganização da estrutura curricular da Faculdade estava completo em 1923. Entre os anos de 1922 e 1923, Richard Pearce, os diretores Celestino Bourroul e Adolpho Lindenberg e os professores Oskar Klotz, Robert Lambert e Geraldo de Paula Souza haviam acertado os termos do plano de reforma, que resumidamente diziam respeito à implantação do regime de tempo integral para as disciplinas pré-clínicas, a necessidade de construção dos edifícios próprios para os laboratórios, administração e departamentos da Faculdade, a construção de um hospital ligado a Faculdade e o limite de número de alunos por turma. Apesar da sintonia de interesse entre os representantes da Fundação Rockefeller e da Faculdade de Medicina, que rapidamente aceitou os termos propostos por Pearce, a aprovação do projeto de reforma pelo governo estadual foi mais lenta e cautelosa. Ela somente viria a ocorrer entre 1924 e 1925, sob a direção de Pedro Dias da Silva, que para tanto gozava de influência política. O ciclo da implementação do modelo fechou-se em 1925, com a "Reforma Pedro Dias", que viria a mudar o nome da instituição para Faculdade de Medicina de São Paulo. Materialmente, no entanto, o modelo 
Rockefeller se consolidaria com a construção da nova sede para a Faculdade, processo que perdurou de 1925 a 1931 e teve Ernesto de Souza Campos como um dos protagonistas.

\subsubsection{Das viagens da comissão de estudos à cátedra}

Com a primeira fase da reforma concluída, restava cumprir as etapas de desdobramento da implantação do modelo, ou seja, a construção dos edifícios e do hospital. De fato, desde 1922 Richard Pearce havia encaminhado à faculdade a sugestão de formar uma comissão para viajar aos Estados Unidos e Europa, sob os auspícios da Rockefeller, e colher subsídios para o projeto das obras. Assim estava disposto no documento enviado em 10 de março de 1922, reproduzido integralmente por Marinho (2013b, p.144):

[...] prontifiquei-me a recomendar à Fundação Rockefeller de convidar uma comissão da Faculdade de Medicina a fim de que visitando os Estados Unidos e outros países estude os métodos em uso tanto na construção de laboratórios e hospitais, como relativamente às questões de administração dessas instituições e métodos de ensino médico.

Deverá fazer parte da comissão um arquiteto.

A questão da necessidade de haver um arquiteto na comissão viria a gerar um embate de opiniões. Para Pedro Dias, a presença do arquiteto era dispensável, pois “um número de prédios públicos de alto valor foi feito por homens do local”. Lambert desconfiava da afirmativa do diretor, levando em conta a situação precária dos prédios até então usados pela faculdade. Para este último, o medo de Pedro Dias era que a Rockefeller insistisse em criar uma estrutura utilitária semelhante ao Colégio Mackenzie, algo que Lambert tratou de enfatizar que utilidade, boa arquitetura e custos razoáveis eram perfeitamente compatíveis ${ }^{50}$. Conforme apontou Marinho (2013b, p.153 [itálicos nossos]), nos ofícios subsequentes entre Lambert e o diretor, ficou sugerido por Pearce que a presença do arquiteto não era obrigatória, mas que um ou dois membros da faculdade fossem ao exterior e observassem os laboratórios a fim de controlar o trabalho do arquiteto para o espaço interno dos edifícios. Ficou também a ressalva de que se oporiam a gastos dispendiosos com a parte externa em detrimento da interna. Em tom firme, Pedro Dias reafirmava sua opinião de que os “detalhes” das construções deveriam estar a cargo

\footnotetext{
${ }^{50}$ Carta de Robert Lambert a Richard M. Pearce, 5 de julho de 1924 [RAC, 305A Sao Paulo Faculty of Medicine
} - Sao Paulo Historical Records VIII, 1.1, 305, 4, 24 A, p.166]. 
dos brasileiros, dizendo ser salutar a ida da comissão ao estrangeiro para basear-se nas ideias mais modernas sobre a organização e construção de edifícios planejados ${ }^{51}$.

Finalmente, no início de 1925, com a reforma aceita nos termos da lei, a comissão foi formada pelo diretor da faculdade. Nesse momento, Ernesto de Souza Campos entrou em cena novamente. Cumprindo a promessa feita em 1924, Pedro Dias o convidou para fazer parte da comissão de professores para visitar os países na Europa e América do Norte, solicitação que o médico teria refutado de antemão pois estava instalado no Rio de Janeiro e satisfeito com o trabalho em Manguinhos. Convencido do contrário pelo professor Aguiar Pupo, recebeu a nomeação para compor o grupo com o consentimento de Carlos Chagas (CAMPOS,1954, p.363). O convite era de conhecimento de Robert Lambert, que em carta a Richard Pearce, comemorou a volta de Souza Campos a São Paulo, quando ambos seguiam preocupados com a sucessão na cadeira de Patologia. Apesar das esperanças que recaiam sobre Cunha Motta, restava ainda a possibilidade de Carmo Lordy assumir a cadeira, conforme pretendia anteriormente, por meio de uma tentativa de permuta ${ }^{52}$.

De acordo com documento enviado a Pearce por Lambert, a possível comissão seria composta pelos seguintes professores, sendo dois representantes de cada partido:

1) Benedicto Montenegro (graduado na Universidade da Pennsylvania e professor substituto de Anatomia);

2) Celestino Bourroul (professor de Parasitologia, clínico e ex-diretor);

3) Alves Lima (professor de Cirurgia);

4) Souza Campos (Patologista arquiteto, graduado em Engenharia antes da Medicina) - (Campos é arquiteto) ${ }^{53}$

Além da perspicácia em tentar criar uma comissão que tivesse elementos dos dois partidos opositores na faculdade, Souza Campos foi inserido como arquiteto, título que de fato não possuía. Era de conhecimento público que Souza Campos havia se formado em engenharia, no entanto, omitia-se a especialidade em agronomia. Para poder nomear Souza Campos para uma comissão que deveria ser de professores da Faculdade de Medicina, instituição da qual não

\footnotetext{
${ }^{51}$ Ofício do diretor Pedro Dias da Silva a Fundação Rockefeller, 16 de junho de 1924[RAC, 305A Sao Paulo Faculty of Medicine - Sao Paulo Historical Records VIII, 1.1, 305, 4, 24 A, p.171-172].

${ }^{52}$ Carta de Richard M. Pearce a Robert A. Lambert, 27 de janeiro de 1925.[RAC, 305A Sao Paulo Faculty of Medicine - Sao Paulo Historical Records VIII, 1.1, 305, 4, 24 A, p.171-172].

${ }^{53}$ Carta de Robert A. Lambert a Richard M. Pearce, 7 de janeiro de 1925, tradução e itálicos nossos [RAC, 305A

Sao Paulo Faculty of Medicine - Sao Paulo Historical Records VIII, 1.1, 305, 4, 24 A, p.171-172].

1)Benedict Montenegro (graduate of the University of Pennsylvania and substitute professor of Anatomy);

2) Celestino Bourroul (professor of Parasitology, clinician and former director);

3) Alves Lima (professor of Surgery);

4) Souza Campos (Pathologist architect, graduated in Engineering before Medicine) - (Campos is an architect)
} 
era membro, Pedro Dias valeu-se da antiga exigência de Richard Pearce sobre a necessidade de haver um arquiteto. Apesar do aparente arranjo, era indiscutível a experiência de Souza Campos em trabalhos de engenharia civil e arquitetura, especialmente por sua contribuição na área médica com o Dispensário Modelo Clemente Ferreira. Assim, Souza Campos pode compor o grupo, sob a confiança de Pedro Dias e dos representantes da Fundação Rockefeller.

Da lista sugerida apenas dois nomes permaneceram: Benedicto Montenegro e Souza Campos. O terceiro professor a compor a equipe foi Luiz de Rezende Puech, da cadeira de Pediatria. Segundo Souza Campos (1954, p.364), Puech foi incorporado ao grupo por interesse da direção da Santa Casa de Misericórdia. No entanto, em carta de Pearce a Lambert, fica evidente que a presença de Puech era desejada também pela fundação, por conta da necessidade dos estudos para o hospital anexo à escola como parte dos acordos, enquanto os estudos dos laboratórios ficariam a cargo de Souza Campos ${ }^{54}$.

A comissão partiu em fins de abril de 1925 para os Estados Unidos, com a previsão de que Souza Campos e Puech só embarcariam para a Europa depois de junho. De antemão, esperavam que todos estivessem de volta a São Paulo em setembro, momento em que Lambert, mesmo com o prazo de seu contrato expirando, ficaria por mais algumas semanas para acordar os planos de construção com a diretoria e a comissão. No itinerário americano estavam previstas visitas a New York, Philadelphia, Baltimore, Washington, St. Louis, Nashville, Cleveland e New Haven, nos Estados Unidos; enquanto no Canadá visitaram Toronto e Montreal ${ }^{55}$.

Em mensagens reproduzidas do diário de Pearce e enviadas à Fundação Rockefeller e a Robert A. Lambert (8 e 10 de junho), constavam as últimas notícias da viagem da comissão. Puech e Souza Campos descreviam as visitas de forma entusiástica, pois na opinião de Pearce eles haviam descoberto o quanto os métodos modernos americanos poderiam ser encaixados na tradição latina de prédios e organização universitários. Reiteraram a necessidade da espera de voltarem a São Paulo para fazerem um relatório ao governo e para darem andamento aos projetos dos prédios. Quanto ao trabalho de Souza Campos com os laboratórios, Pearce afirmou que Souza Campos estava considerando seriamente em colocar todos os laboratórios em um único prédio à maneira americana. Pearce sugeriu a Souza Campos observar cuidadosamente o caso da Universidade de Yale, onde o prédio de Patologia é ligado ao hospital e os outros

\footnotetext{
${ }^{54}$ Carta de Richard M. Pearce A. Robert A. Lambert, 8 de abril de 1925 [RAC, 305A Sao Paulo Faculty of Medicine - Sao Paulo Historical Records VIII, 1.1, 305, 4, 24 A, p.271].

${ }^{55}$ Carta de Richard M. Pearce A. Robert A. Lambert, 1 de maio de 1925 [RAC, 305A Sao Paulo Faculty of Medicine - Sao Paulo Historical Records VIII, 1.1, 305, 4, 24 A, p.287].
} 
laboratórios estão dispostos em um único prédio. Tocou também no assunto do prédio de Higiene, que por conta de interesses do estado sugeria que ficasse em prédio separado. Sobre a localização dos prédios dos laboratórios e o hospital, Souza Campos e Puech defendiam a construção em um mesmo terreno ${ }^{56}$, corroborando uma antiga recomendação de Richard Pearce.

Embora os planos estivessem seguindo o que era esperado por Pearce, ele temia que estes pudessem exceder as provisões financeiras, tendo em vista as ideias de grandeza comuns no Brasil. O pressentimento de Pearce mostrou-se certeiro. $\mathrm{O}$ valor estimado para doação pela fundação, que em 1925 era de 5.300 contos de réis já com o reajuste de câmbio, passou a ser considerado insuficiente pela comissão e pela diretoria da faculdade, gerando um clima de insatisfação de ambos os lados ${ }^{57}$. Outra questão prevista pelos representantes da Rockefeller era uma possível discórdia quanto aos planos para o Instituto de Higiene. Existia entre a diretoria da faculdade, do Instituto de Higiene e a comissão um conflito de interesses quanto ao status do prédio, pois se Pedro Dias insistia que fizesse parte da escola, ficando seu plano a cargo da comissão, Paula Souza desejava orientá-lo pessoalmente. Conforme apontou Farley (2003, p.209), a tentativa frustrada de Pedro Dias de recolocar sob o controle da faculdade o recém independente Instituto de Higiene era uma estratégia para angariar mais fundos para a construção dos laboratórios da escola, pois somente para o edifício de Higiene estava destinada a verba de 1.500 contos de réis dos 5.300 totais, valor que Puech e Souza Campos consideravam exagerado.

Para George Strode, membro do staff da Rockefeller, a solução para equacionar as disputas entre o desejo de controle de Pedro Dias e de autonomia de Paula Souza seria construir o Instituto no mesmo terreno da faculdade para gerar uma impressão de que o Instituto era uma divisão de ensino e pesquisa da Faculdade de Medicina, tal como o Health Board havia planejado (apud FARLEY, 2003, p.208). No entanto, o Instituto deveria contar com a verba total a ele destinado, dada a envergadura de sua projeção como instituto independente da Faculdade $^{58}$.

\footnotetext{
${ }^{56}$ Relatório feito por Richard M. Pearce sobre as notícias da comissão, com cópia enviada a Robert A. Lambert, 11 de junho de 1925 [RAC, 305A Sao Paulo Faculty of Medicine - Sao Paulo Historical Records VIII, 1.1, 305, 4, 24 A, p.303].

${ }^{57}$ Carta de Richard M. Pearce a Robert Lambert, 11 de junho de 1925 [RAC, 305A Sao Paulo Faculty of Medicine - Sao Paulo Historical Records VIII, 1.1, 305, 4, 24 A, p.306].

${ }^{58}$ Carta de Robert A. Lambert a Richard M. Pearce, 11 de setembro de 1925 [ RAC, 305A Sao Paulo Faculty of Medicine - Sao Paulo Historical Records VIII, 1.1, 305, 4, 24 A, p. 318].
} 
Em carta enviada a Souza Campos em resposta a seus projetos e ideias sobre as futuras obras da faculdade, Robert Lambert discorria em tom de crítica e advertência sobre a viabilidade dos planos cogitados pelo brasileiro, deixando claro que deveria ser levado em conta as diferenças da realidade entre as universidades norte-americanas e a faculdade paulista, especialmente em relação à destinação de verba e a união das múltiplas cadeiras em departamentos comuns ${ }^{59}$, aconselhando que seus planos fossem praticáveis e capazes de execução imediata.

Em evidente controvérsia, os grandiosos planos dos “bandeirantes” chocavam-se com a intenção da Fundação Rockefeller, que não se sentia incumbida de financiar um projeto físico que ultrapassasse os limites da funcionalidade e das condições locais. No entanto, a concretização do modelo de educação médica introduzido pela Rockefeller passava não somente pela reorganização em departamentos e pela instituição do tempo integral, mas pela construção dos laboratórios e do hospital para o ensino clínico. De acordo com essas necessidades, a faculdade teria as condições físicas para a prática da pesquisa laboratorial e das aulas práticas nas áreas clínicas. O número reduzido de alunos, um dos critérios exigidos, não dizia respeito apenas a uma seleção meritocrática, mas à necessidade de assegurar espaço, equipamento e financiamento para as pesquisas laboratoriais e manter o nível de excelência da instituição, de acordo com as possibilidades financeiras da escola, uma questão de responsabilidade do governo paulista. A mesma medida deveria ser guardada para a existência dos departamentos, que, na visão dos americanos, deveriam ter número reduzido de profissionais no cargo de titular e uma hierarquia mais rígida em relação aos seus assistentes, algo que de fato contrastava com a realidade vigente na faculdade. Ou seja, era defendida pelos representantes da Rockefeller como necessária a construção física da faculdade de acordo com os termos do plano de reforma; no entanto, qualquer tentativa de ultrapassar os limites orçamentários propostos seriam barrados e entendidos como excedentes aos objetivos finais.

A despeito de Souza Campos (1954, p.365) afirmar que a comissão somente regressara a São Paulo em 1926, documentos de seu arquivo pessoal e da Fundação Rockefeller confirmam o retorno em outubro de 1925, momento crucial para a definição de sua carreira. Pedro Dias havia assumido o desejo de que Souza Campos permanecesse ligado à Faculdade de Medicina em São Paulo para dar sequência aos trabalhos desenvolvidos na comissão dos

\footnotetext{
${ }^{59}$ Carta de Robert A. Lambert a Emesto de Souza Campos, 21 de julho de 1925 [RAC, 305A Sao Paulo Faculty
} of Medicine - Sao Paulo Historical Records VIII, 1.1, 305, 4, 24 A, p.325-329] 
professores. No entanto, o próprio Souza Campos dava indícios de que pretendia continuar empregado em Manguinhos. Em carta a Robert Lambert, de F. W. O’Connor, cientista da Escola de Medicina Tropical de Londres que acompanhou a comissão paulista, confirmava ter conversado informalmente com Souza Campos durante a viagem a respeito de seu futuro em São Paulo. Souza Campos dizia ter discutido a questão com Carlos Chagas, que era fortemente contrário a sua partida do Oswaldo Cruz. Além disso, dizia estar mais inclinado à área da pesquisa do que a docência ${ }^{60}$. A sondagem feita pelos americanos não era sem propósito. Apesar do acordo de se manterem afastados do “emaranhado da patologia”, Lambert ainda não tinha uma definição clara sobre o futuro de sua cadeira e existia a possibilidade de Souza Campos ser contratado para assumi-la, por aspiração de Pedro Dias ${ }^{61}$.

Com Montenegro, Souza Campos e Puech de volta iniciaram-se as discussões a respeito dos planos de construção. Para Lambert, o progresso da comissão, composta por Campos e Puech, era lento, por conta da grande massa de informações acumulada. Sentindo que sua presença pudesse ter um efeito contrário ao desejado, Lambert anunciava sua partida para o Uruguai, Paraguai e interior brasileiro. Embora a Secretaria do Interior tenha pressionado a comissão para sumarizar com urgência as informações, Souza Campos sentia-se impelido a, primeiramente, escrever uma descrição detalhada de tudo que tinha visto ${ }^{62}$.

Neste ínterim, a situação profissional de Souza Campos estava indefinida, entre seu cargo no Instituto Oswaldo Cruz e os trabalhos da comissão. Pressionado a regressar ao Rio, Souza Campos hesitou, permanecendo em São Paulo e abrindo mão de seus vencimentos em Manguinhos durante o processo $^{63}$. Enquanto Souza Campos produzia o relatório, que daria origem ao livro Estudos sobre o problema universitário, publicado em 1938, sua carreira na instituição paulista era negociada com Pedro Dias. Provavelmente, por insistência do diretor, pela possibilidade de assumir um cargo estável na faculdade e dar andamento às obras dos laboratórios, mudou de decisão e aceitou retornar ao solo paulistano. Em 13 de dezembro de 1925, a imprensa noticiava a nomeação de Souza Campos:

\footnotetext{
${ }^{60}$ Carta de F. W. O’Connor a Robert. A. Lambert, 15 de julho de 1925 [RAC, 305A Sao Paulo Faculty of Medicine - Sao Paulo Historical Records VIII, 1.1, 305, 4, 24 A, p.323-324]. Cartas com notícias semelhantes seguiram-se em 27 de agosto e 5 de setembro de 1925.

${ }^{61}$ Carta de Robert A. Lambert a Richard M. Pearce, 19 de agosto de 1925 [RAC, 305A Sao Paulo Faculty of Medicine - Sao Paulo Historical Records VIII, 1.1, 305, 4, 24 A, p.340].

${ }^{62}$ Carta de Robert A. Lambert a Robert M. Pearce, 9 de novembro de 1925 [RAC, 305A Sao Paulo Faculty of Medicine - Sao Paulo Historical Records VIII, 1.1, 305, 4, 24 A, p.389].

${ }^{63}$ Carta de Ernesto de Souza Campos a Leocádio Chaves, 23 de outubro de 1925 [Fundo Ernesto de Souza Campos, Curriculum Vitae, Vol. I].
} 
Por decreto de ontem foi nomeado o Sr. Ernesto de Souza Campos para o cargo de lente catedrático da $3^{\text {a }}$ cadeira do $2^{\circ}$ ano, "Histologia e Embriologia” da Faculdade de Medicina de São Paulo.

O jovem cientista patrício, que vai ser um ótimo elemento para a Faculdade paulista, onde fez o seu curso médico, foi um dos mais brilhantes alunos dessa casa de ensino, como já o fora na Escola Polytechnica, que anteriormente cursou [...].

Tendo feito concurso, há tempos, para outra cadeira da Faculdade de Medicina, a sua competência e dedicação às pesquisas científicas ficaram ali bem patenteadas, e essas qualidades o distinto patrício, que é assistente do Instituto de Manguinhos, continuou a afirmar em várias comissões científicas no estrangeiro, onde representou o nosso Estado. Entrando agora para a congregação da Faculdade que o diplomou, inicia o dr. Souza Campos a sua carreira definitiva no magistério médico, onde terá novos ensejos de revelar todos os seus méritos de estudioso e pesquisador nobremente devotado à ciência ${ }^{64}$.

O acordo feito para acomodar Souza Campos, no entanto, não parou por aí. Nomeado para a cadeira de Histologia, em questão de dias teve sua cadeira permutada com a de Carmo Lordy, passando a ser o titular de Microbiologia (Bacteriologia). Na visão dos americanos, a permuta, embora não inteiramente aprovada, abria caminho para o desenvolvimento da bacteriologia, um assunto que consideravam “morto" desde o falecimento de Alexandrino Pedroso $^{65}$. Assim, também se adicionava outro departamento de tempo integral à escola, condição de Souza Campos para permanecer em São Paulo, pelo desejo de atuar em pesquisa experimental. Naquele mesmo ano, enviou a Pearce carta anunciando sua mudança do Instituto Oswaldo Cruz para a Faculdade de Medicina, sentindo-se muito entusiasmado com o novo caminho que a Faculdade de Medicina de São Paulo estava tomando, não somente em relação aos prédios e ao hospital, mas igualmente nos métodos de ensino, e sem demora pediu ajuda financeira para equipar seu laboratório, algo concedido pela Fundação no ano seguinte ${ }^{66}$.

3.2.2 O Escritório de Obras e a concretização dos planos: o majestoso prédio da medicina bandeirante

\footnotetext{
${ }^{64}$ Sem autor. Sem título, 13 de dezembro de 1925 [Fundo Ernesto de Souza Campos, Curriculum Vitae, Vol. I].

${ }^{65}$ Carta de Robert A. Lambert a Richard M. Pearce, 22 de dezembro de 1925 [RAC, 305A Sao Paulo Faculty of

Medicine - Sao Paulo Historical Records VIII, 1.1, 305, 4, 24 A, p.419]. Em anotação feita por Lambert na mesma, Dr. Carmo Lordy estava satisfeito com a permuta.

${ }^{66}$ Carta de Emesto de Souza Campos a Richard M. Pearce, 23 de dezembro de 1925 [RAC, 305A Sao Paulo

Faculty of Medicine - Sao Paulo Historical Records VIII, 1.1, 305, 4, 24 A, p.420].
} 
No ano de 1926, as negociações para a organização dos planos dos laboratórios e do hospital continuaram. Puech, Souza Campos, Pedro Dias e Paula Souza solicitavam a vinda de Richard M. Pearce ao Brasil para autorizar os projetos, que excediam o orçamento. Prevendo que sua ida seria uma ocasião para um pedido de mais verbas, Pearce procurou adiá-la o máximo possível. De acordo com Marinho (2013b, p.155-158) a questão do orçamento continuou em pauta, sendo necessária a ida de Rezende Puech a Nova York para acertar os detalhes dos planos, em evidente tentativa de controlar o "ímpeto" de grandiosidade dos projetos de Souza Campos. Pearce sugeriu a redução de alguns espaços e laboratórios no plano original, o que resultou em diminuição de $10 \%$ do valor do $20 \%$ excedente. Por fim, cedendo à pressão dos paulistas, a fundação autorizou a suplementação necessária. A agilidade da Fundação Rockefeller em dar suporte financeiro às obras dos laboratórios não foi acompanhada pelo governo estadual, responsável pela verba destinada à construção do hospital. Em razão da mudança no cargo executivo após o falecimento de Carlos de Campos, as obras do hospital, que somente seriam iniciadas em 1938, ficariam no papel e caíram no esquecimento após a Revolução de 1930.

Em tom solene e profético, Souza Campos foi apresentado como catedrático no início do ano letivo de 1926, sendo responsável pela aula inaugural no prédio destinado à cadeira de Microbiologia, a antiga sede do Instituto de Medicina Legal, no complexo do Araçá. Sua aula ocorreu no mesmo dia da comemoração de aniversário da escola e consequente homenagem ao patrono Arnaldo Vieira de Carvalho, realizada na sede da Rua Brigadeiro Tobias, demarcando e unindo "o passado e o futuro" da Faculdade de Medicina. Assim foram noticiados os dois eventos pela imprensa:

Duas cerimônias de incontestável relevo gravaram-se na história da nossa escola médica -- uma no edifício novo, à volta de um novo professor, figura das mais brilhantes da nova geração de cientistas formados no ambiente novo e virente da terra dos bandeirantes; a outra, como que em contraste, no velho edifício da rua Brigadeiro Tobias, desviando a atenção para um dos mais velhos e respeitáveis mestres, que fez a recordação de velhas coisas relativas à velha ideia da criação de uma Faculdade de Medicina em nosso meio ${ }^{67}$.

A aula de Souza Campos foi também sua tribuna. Nela representou os projetos dos aliados do modelo Rockefeller, que se consolidava naquele ano com a primeira turma iniciada

\footnotetext{
${ }^{67}$ Folha da Noite. 7 de abril de 1926, p.1. [Fundo Ernesto de Souza Campos, Curriculum Vitae, Vol. I].
} 
pelos novos regulamentos. Deu o tom dos desafios que a escola se propunha a alcançar e salientou a importância da construção de sua futura sede:

Conhecedor profundo da nossa escola, onde conquistou o título de médico com que veio acrescer o número dos que já possuía, o dr. Souza Campos iniciou a sua lição fazendo um estudo comparativo da nossa Faculdade com as escolas médicas estrangeiras, tendo oportunidade de demonstrar como até agora temos vivido num regime quase asfixiante, dada a carência de acomodações de que felizmente já nos vamos libertando. Campo aberto aos estudantes, para que se vão acamaradando com as pesquisas desde cedo. O professor é apenas o orientador e não o massudo discursador palavroso. Exemplos de cientistas, cujo renome corre mundo e fizeram as suas primeiras grandes descobertas durante a vida acadêmica -- cita-os vários o novo catedrático. Amor pelo laboratório, todos. Ainda mais agora que o governo, num rasgo de luminosa orientação, está dotando a nossa escola de aparelhamentos que a transformam em um vasto campo para os voos da imaginação dos moços. A Comissão Rockefeller mereceu do novo professor os maiores encomias, que, aliás, ninguém lhe regatearia. A sua obra gigantesca foi resumida em pinceladas incisivas, que vieram irmanar na internacionalidade da ciência as cores da mais acatadas bandeiras do mundo civilizado. Chegou até nós a ação benfazeja dessa instituição universal. E chegou e a mais e mais se prende a nós, graças à política administrativa de Arnaldo Vieira de Carvalho, seguida com segurança pelos seus sucessores na direção da Faculdade ${ }^{68}$.

A pedra fundamental das obras do novo bloco médico foi inaugurada a 25 de janeiro de 1928, data de comemoração da cidade de São Paulo. Contando com a verba destinada aos laboratórios pela Rockefeller, Souza Campos, diretor do Escritório Técnico de Obras, iniciou os trabalhos de construção, junto ao escritório de engenharia e arquitetura de Ramos de Azevedo.

Em 27 de outubro de 1930, Pedro Dias da Silva foi deposto do cargo de diretor da faculdade como resultado do movimento armado liderado por Getúlio Vargas, que saíra vitorioso poucos dias antes com a queda do presidente da República, Washington Luís. Em cerimônia solene foi empossado como seu sucessor, em caráter provisório, Ernesto de Souza Campos, tendo como vice diretor Rezende Puech, que ficariam responsáveis pela finalização das obras da sede e por uma reforma didática da Faculdade, ambos indicados pelo secretário do Interior do governo provisório, José Carlos de Macedo Soares ${ }^{69}$. Apesar de ter tomado posse de

\footnotetext{
${ }^{68}$ Folha da Noite. 7 de abril de 1926, p.1 [Fundo Ernesto de Souza Campos, Curriculum Vitae, Vol. I].

${ }^{69}$ O Estado de S. Paulo. Faculdade de Medicina, 29 de outubro de 1930 [Fundo Ernesto de Souza Campos, Curriculum Vitae, Vol. II]. José Carlos de Macedo Soares, em 1930, "deu apoio ativo à candidatura presidencial de Getúlio Vargas, lançada pela Aliança Liberal. Após a deposição de Washington Luís em outubro daquele ano, e antes mesmo da posse de Vargas, participou das negociações entre os membros paulistas da Aliança Liberal em torno da formação do novo secretariado estadual, cabendo a ele próprio a Secretaria de Justiça (sic). Esse secretariado foi mantido por Vargas, mas os paulistas tiveram de aceitar, em contra-partida, a
} 
uma forma laureada, segundo a imprensa local, por conta da instabilidade política do momento, Souza Campos permaneceu no cargo de 28 de outubro a 2 de dezembro, quando pedira exoneração, sendo posposto por Guilherme Bastos Milward, o professor catedrático mais velho em exercício na casa, já que Luiz de Rezende Puech igualmente pediu demissão ${ }^{70}$. A situação de conflito é explicada pela indicação feita pelo interventor federal em São Paulo, João Alberto Lins de Barros para que Arthur Neiva assumisse a Secretaria do Interior em lugar de Macedo Soares, investidura que exerceu por pouco tempo, pois em fevereiro foi indicado para a interventoria federal na Bahia. As tramas políticas enlaçadas sobre a questão podem ser compreendidas pela carta de Macedo Soares enviada a Arthur Neiva, copiada a Ernesto de Souza Campos:

Fiquei muito chocado pela maneira com que V. tratou os meus dois amigos que, n’uma hora difícil e de sacrifícios, aceitaram a direção do S. S. e da Faculdade de Medicina. Ao primeiro, Prof. A. de Almeida Prado, atual Presidente da Sociedade de Medicina, e possuidor de títulos incontáveis, que o fazem merecedor de alta consideração, V. sob pretexto de dar posse na Secretaria, sem solenidade, ao novo Diretor, impediu de dizer o que entendesse, como é de praxe, no ato da transmissão do cargo. Ao segundo, Prof. Ernesto de Souza Campos, o homem que, desculpe-me a franqueza, as boas normas administrativas aconselhariam naturalmente para o posto até, pelo menos, a próxima conclusão das obras da Faculdade, foi tratado com maior desconsideração ainda. Um ofício extemporâneo colocou-o na posição incômoda (e, não compreendendo a razão do fato) de não ter a quem entregar a direção da Escola, forçando-o a procurar o lente mais antigo, par receber a investidura.

Aproveito a oportunidade para pedir o favor de comunicar ao Coronel João Alberto que o Dr. Ernesto de Souza Campos, ao contrário do que foram dizer ao Interventor, não é meu parente, nem mesmo longinquamente. É meu amigo há algumas décadas, e por isso mesmo, conhecendo seu grande valor, é que propus seu nome ao Governo Provisório para Diretor da Faculdade de Medicina. Os aplausos com que a nomeação foi recebida pelos corpos docente e discente, e pela classe médica em geral, deram-me plena convicção de haver praticado um ato acertado $^{71}$.

\footnotetext{
imposição do nome do tenente João Alberto para a interventoria federal no estado. Em pouco tempo, as relações entre João Alberto e seu secretariado se deterioraram, levando à demissão coletiva de todos os secretários 40 dias após terem assumido seus postos. Macedo Soares continuou, porém, ativo nas articulações em torno dos rumos da política paulista nos meses seguintes. Em julho de 1931 apoiou a indicação de Laudo de Camargo como substituto de João Alberto” (FUNDAÇÃO GETULIO VARGAS, 2016).

${ }^{70}$ Ofício de Ernesto de Souza Campos a Arthur Neiva, 15 de dezembro de 1930 [Fundo Ernesto de Souza Campos, Curriculum Vitae, Vol. II].

${ }^{71}$ Carta de José Carlos de Macedo a Arthur Neiva, 16 de dezembro de 1930 [Fundo Ernesto de Souza Campos, Curriculum Vitae, Vol. II].
} 
Apesar de terem saído da diretoria da Faculdade, Souza Campos e Rezende Puech continuaram no Escritório Técnico, por intermediação do diretor Sérgio Meira Filho com Arthur Neiva, podendo finalizar as obras da instituição. Nesse mesmo momento, de acordo com ofício de Milward como diretor interino, foi nomeada uma comissão de professores -- Luiz de Rezende Puech, Domingos Goulart de Faria, Floriano Paulo de Almeida e Paulo de Toledo Artigas --, sob a presidência de Souza Campos, para dar andamento ao projeto da herma em homenagem a Arnaldo Vieira de Carvalho no jardim fronteiriço do novo prédio, ideia de Ernesto de Souza Campos durante sua direção na escola ${ }^{72}$.

A imprensa paulista, ao longo dos anos de 1927 até 1931 publicou, passo a passo, o andamento da moderna obra que alçaria São Paulo à cidade com "um dos melhores complexos médicos do mundo”, epopeia encerrada em 15 de março de 1931, com a solenidade de inauguração do “monumental” e “majestoso” prédio até hoje usado pela Faculdade de Medicina da Universidade de São Paulo. Completado o ciclo que levou à efetivação do projeto de modernização da educação médica paulista, a locomotiva bandeirante trilhava um novo caminho para o progresso: a criação da universidade. Paralelamente à direção das obras e das pesquisas em seu laboratório, Souza Campos deu início ao que viria a chamar posteriormente de seu “apostolado" -- a missão de defender a criação e a organização de uma universidade em solo paulista. De forma progressiva, Souza Campos ganhou visibilidade pública nacional e internacional por conta da construção do "imponente edifício” da faculdade, e na imprensa passou a escrever, com base nos conhecimentos adquiridos na viagem ao exterior sob o patrocínio da Fundação Rockefeller, sobre as organizações universitárias estrangeiras. Nesse tempo, o debate sobre a criação da universidade paulista já estava em andamento desde a publicação, em 1925, do livro A crise nacional, de Julio de Mesquita Filho e do inquérito por ele promovido sobre a questão em O Estado de S. Paulo.

\subsection{POR UMA UNIVERSIDADE EM SÃO PAULO: DA CAMPANHA À FUNDAÇÃO}

Apesar de não ter participado diretamente como colaborador dos inquéritos da Associação Brasileira de Educação e do jornal $O$ Estado de S. Paulo sobre a questão

\footnotetext{
${ }^{72}$ Ofício de Guilherme Bastos Milward a Ernesto de Souza Campos, 18 de dezembro de 1930 [Fundo Ernesto de Souza Campos, Curriculum Vitae, Vol. II]
} 
universitária, Ernesto de Souza Campos passou a integrar os debates sobre o ensino superior nas discussões ocorridas no Rotary Club de São Paulo e na Faculdade de Medicina nos anos finais da década de 1920, desenvolvendo o que posteriormente classificou como o seu verdadeiro “apostolado”. Em suas palavras, “desde 1920, quando tive oportunidade de observar, de perto as grandes conquistas universitárias de outros países, procurei conjugar os meus esforços aos poucos brasileiros que se inscreveram neste apostolado ${ }^{73}$ ” (CAMPOS, 1940, p. 375-376).

De acordo com o Dicionário Crítico de Teologia (LACOSTE, 2004, p.175-177), a palavra em grego apostolos designava na maioria das vezes o cumprimento de uma missão (frota ou expedição), ou o próprio documento que a legitimava, sendo aplicada excepcionalmente a pessoas. Na literatura cristã primitiva, o termo apostolos era usado de acordo com o antigo direito oriental, segundo o qual "um enviado representava e substituía seu mandatário durante toda a duração de uma missão particular”. Nas escrituras de Paulo encontra-se pela primeira vez o emprego da palavra apostolado como um termo técnico para designar um “cargo ligado à pessoa do (a.) [apóstolo], enquanto depositário permanente de uma missão” instruída pela Espírito. A partir desta definição podemos depreender o sentido de apostolado que Souza Campos utilizou para designar sua obra em prol da universidade. Imbuído do repertório moral cristão e do discurso de regeneração nacional que fez parte de sua formação na Escola Politécnica e na Faculdade de Medicina, Souza Campos colocava-se ao lado dos outros “apóstolos”, homens esclarecidos que tinham como missão remodelar o país por meio da cultura e das ciências. Assim, participou do conjunto de intelectuais, o “apostolado”, ao inserir-se no debate sobre o ensino superior, contribuindo para o cumprimento da missão perante a nação: a criação de verdadeiras universidades, baseadas no espírito científico, que seriam os centros de formação das elites, líderes da sociedade brasileira rumo ao progresso e à democracia.

Reverberando as questões levantadas e defendidas nos inquéritos de 1926 de OESP e de 1928 da ABE, as plenárias do Rotary Club de São Paulo tornaram-se palco de importantes discussões da elite intelectual paulista a respeito das especificidades desejadas à futura Universidade de São Paulo, tornando-se representativo dos diferentes pontos de visão e

\footnotetext{
${ }^{73}$ Importante ressaltar que o conhecimento de Souza Campos sobre as organizações universitárias na Europa e América do Norte não constitui caso inédito e isolado no debate sobre o ensino superior. Outros intelectuais apresentaram esses saberes como subsídios para suas argumentações, discutindo os diferentes modelos universitários, em especial o francês, o alemão e o norte-americano. Para maior compreensão deste aspecto, consultar o inquérito promovido pela ABE , em O problema universitário brasileiro (1929).
} 
interesses em torno desse projeto ${ }^{74}$.

\subsection{1 - O "espírito de uma verdadeira organização universitária”}

De acordo com Cunha (1980), as primeiras iniciativas concretas de criação de universidades no Brasil surgiram durante a Primeira República, com as universidades de "vida curta” -- a Universidade de Manaus (1909), a Universidade de São Paulo (1911) e a Universidade do Paraná (1912) ${ }^{75}$; e as de "vida longa” -- a Universidade do Rio de Janeiro (1920) e a de Minas Gerais (1927). As três primeiras, resultantes de um momento no qual a desoficialização do ensino estava em processo, especialmente após a Reforma Rivadávia Corrêa, são classificadas por Cunha como de “vida curta” justamente por não terem vingado, diferente do que ocorreu com as duas criadas na década de 1920. Uma diferença existente entre as universidades de "vida curta” e as de "vida longa” teria sido o estatuto legal das instituições: as que foram temporárias eram resultado de iniciativas privadas, enquanto as duas últimas foram iniciativas oficiais. Apesar de haver causas específicas que explicam o insucesso dessas universidades privadas, um dos principais pontos estava na fragilidade em relação à estabilidade financeira, diferentemente das universidades do Rio de Janeiro e de Minas Gerais, que recebiam recursos governamentais.

A primeira instituição universitária oficial do país, a Universidade do Rio de Janeiro, foi criada a partir da aglutinação das faculdades federais de Medicina, Engenharia e Direito, porém, sem efetiva integração entre elas. Esta forma de implementação teria suscitado críticas por seu funcionamento de "fachada”, já que a instituição universitária permaneceu no campo

\footnotetext{
${ }^{74}$ Para Cardoso (1982, p.63), a fundação da Universidade de São Paulo, em 1934, foi menos um resultado de campanhas e iniciativas educacionais renovadoras do que a chegada ao poder do representante do "grupo do Estado", Armando de Salles Oliveira, como interventor do governo Vargas no estado paulista. No entanto, a "campanha pela Universidade", elemento fundamental do projeto político e ideológico do grupo, não constituiu um movimento isolado em defesa da criação da universidade. O tema foi debatido pela imprensa, por professores e intelectuais, em instituições de ensino e associações de caráter civil, o que leva a crer que o debate a respeito da construção da universidade foi mais amplo que o projeto encetado pelo jornal. Essa característica, que não configurou o objeto de investigação de Cardoso, focada em identificar os elementos do projeto defendido pelo partido ideológico composto no "grupo do Estado", demonstra a complexidade do tema e a diversidade de sujeitos e instituições envolvidas, sendo uma das causas que levaram, posteriormente, a processos de crise e disputas entre diferentes grupos pelo controle da política institucional universitária.

${ }^{75}$ Embora Cunha classifique a Universidade do Paraná como de "vida curta", a historiografia aponta traços de continuidade desta universidade, que foi oficialmente desmembrada em faculdades por conta da Reforma Carlos Maximiliano em 1915, com a Universidade Federal do Paraná. Para aprofundamento sobre a questão, consultar Campos (2009) e Wachowicz (1983).
} 
simbólico, situação que viria a reavivar o debate em torno da questão universitária ao longo da década de 1920. Apesar das críticas à forma pela qual foi criada a URJ, a reunião das faculdades profissionais pré-existentes como forma de criar a instituição universitária tornou-se modelo para as futuras universidades, figurando uma característica histórica do ensino universitário brasileiro (CUNHA, 1980; MENDONÇA, 2000).

Foi neste contexto institucional que a ABE e o OESP reavivaram e intensificaram o debate em torno da questão do modelo de universidade que deveria ser implantado no país. De modo estrutural, no que diz respeito aos modelos de universidade e sua principal função, as discussões giravam em torno da vocação da universidade como centro de pesquisa científica, em contraposição à ênfase dada até então a sua função de formação profissional (CUNHA, 1980; FÁVERO, 2006; MENDONÇA, 2000).

Conforme apontou Carvalho (1998), para a Associação Brasileira de Educação, nascida após o malogro do partido político Ação Nacional, em outubro de 1924 na capital federal, a educação era um fator preponderante para possibilitar as reformas políticas necessárias para o país. Aglutinando pessoas em torno do civismo como expressão da dimensão política do grupo no discurso educacional, a partir de 1927, a associação passou a ter maior projeção nacional por meio de campanhas educacionais e organizações de conferências. Apesar de terem um repertório comum a respeito da importância da educação como instrumento para a regeneração nacional, a entidade era composta por diferentes grupos políticos e ideológicos que disputavam o controle da atuação institucional. Uma das disputas existentes na ABE girava em torno da questão da educação do povo, voltada à alfabetização, e das elites, centrada no ensino superior. As diferentes concepções teriam levado a uma polarização interna da organização, representada por seus defensores, respectivamente: Fernando de Magalhães e Ferdinando Labouriau. Para Carvalho (1998, p.212), na ABE

\footnotetext{
A repartição educação do 'povo'/ educação das 'elites' divide o campo em que se articularam, expressando a função de que se investiam os educadores sediados na ABE: a de 'elites' às quais cabia conceber e executar projetos de educação do 'povo' que efetivassem a Ordem e o Progresso tais como programavam. Neste campo, as propostas de educação de 'elites' - a remodelação da escola secundária e a reorientação do ensino superior - tiveram primazia como tema de estudos e debates.
}

Fundamentados no nacionalismo político do pensamento de Alberto Torres, os 
principais articuladores do inquérito da ABE compreendiam a universidade como "usina" de formação de uma nova elite dirigente, uma “aristocracia mental” que pensaria o Brasil de forma prática e racional, representando e liderando o povo, ainda analfabeto, para os verdadeiros interesses de ordem moral e econômica do país. Entrementes, mediante uma matriz política que privilegiava o regionalismo paulista como exemplo e guia para o nacional, a universidade era entendida por Júlio de Mesquita Filho e seus colaboradores como local de formação de alta cultura, onde os mais aptos intelectualmente formulariam o "problema brasileiro” e partiriam para o esclarecimento do povo, rumo aos trilhos da democracia. Dessa forma, em ambos inquéritos era consensual que à elite intelectual, formada nas universidade com bases científicas, caberia a direção política do país (BONTEMPI Jr., 2017).

Em São Paulo, a bandeira da formação das elites na universidade foi hasteada com artigo publicado em O Estado de S. Paulo. De acordo com Bontempi Jr. (2002, p.26),

Se o imperativo de 'educar o povo’ marcara os primeiros anos da década,
de 1925 em diante, o foco das discussões passou a ser a educação das
elites. Essa mudança de perspectiva foi desencadeada pelo artigo A crise
nacional (1925), de Júlio de Mesquita Filho, em que este defende pela
primeira vez a criação de uma universidade em São Paulo, afirmando ser
um dos fatores determinantes do caos político do país naquele início de
década a ausência de uma elite intelectual capaz de compreender os
problemas nacionais e de dar a eles solução adequada.

Dando sequência às preocupações levantadas por Mesquita Filho e demonstrando o poder de articulação do OESP em seu envolvimento com questões políticas e educacionais, foi feito o Inquérito sobre a Instrução Pública em São Paulo, em 1926, encomendado pelo diretor do jornal e organizado por Fernando de Azevedo. Esse inquérito fortaleceu as bases da política educacional do "grupo do Estado", que culminou na “campanha pela Universidade” durante o final da década de 1920 e início de 1930, e na própria fundação da Universidade de São Paulo, em 1934, auge da ação do grupo no projeto de construção das elites dirigentes paulistas. Para o grupo, porta voz da Comunhão paulista ${ }^{76}$, a universidade seria o principal pilar para o projeto de regeneração política, pois nela se formaria a “elite orientadora” que lideraria o processo de saída da crise nacional por meio do conhecimento científico (CARDOSO, 1982).

\footnotetext{
${ }^{76} \mathrm{~A}$ Comunhão paulista seria um grupo suprapartidário que tinha "visão dos grandes problemas da nacionalidade" e enxergavam o estado de São Paulo como a unidade chave para a resolução destes, por sua liderança que advinha historicamente da supremacia paulista. "A Comunhão paulista era a representação ideológica que o 'grupo do Estado' fazia de si mesmo” (CARDOSO, 1982, p.40-41).
} 
Para Cardoso (1982, p.60-63), o inquérito realizou-se em um ambiente de críticas à Reforma do Ensino Federal, de 1925, a qual reforçava a manutenção do molde da Universidade do Rio de Janeiro como modelo para a criação das congêneres estaduais. Desde esse episódio, o jornal liderava uma "campanha educacional” que tinha como propósito fundamental defender a criação das faculdades de Letras e de Filosofia, onde se disseminariam os estudos desinteressados e de alta cultura, responsável pela formação dos pensadores dos problemas nacionais. Entre as iniciativas defendidas na campanha estava a criação do Liceu Franco-Brasileiro, liderada pelo jornal junto a George Dumas, professor de Sociologia da Universidade Sorbonne e futuro promotor das relações entre São Paulo e França na contratação dos professores estrangeiros para a Faculdade de Filosofia, Ciências e Letras da USP, em 1934. Entre 1927 e 1929, professores franceses tiveram conferências publicadas no matutino, nas quais versavam sobre a fundação de uma Faculdade de Filosofia e Letras e uma de Ciências, com o objetivo de tornar o ensino vinculado à pesquisa, de elevar o ensino secundário e de formar intelectuais para o estudo desinteressado. Estas conferências foram importantes para a “campanha pela Universidade” do jornal, sendo compreendidas por Júlio de Mesquita Filho como parte da evolução da ideia de universidade que levou à fundação da USP e ao contato com os professores da missão estrangeira.

Articuladas de forma a induzir a convergência das respostas dos colaboradores com o pensamento defendido por Fernando de Azevedo e pelo "grupo do Estado", as questões do inquérito relacionadas ao ensino superior giravam em torno da criação de uma universidade orientada pelo "espírito universitário moderno", que contribuísse para o progresso do saber humano universal e consequentemente para a cultura nacional, unindo em um único sistema as faculdades profissionais, os institutos técnicos e os de altos estudos. De maneira geral, os inquiridos, Rui de Paula Souza, Mario de Souza Lima, Ovídio Pires de Campos, Raul Briquet, Theodoro Ramos, Reynaldo Porchat e Artur Neiva, defenderam a existência de uma universidade aos moldes das necessidades de São Paulo, (com exceção de Ovídio Pires de Campos, que considerava a iniciativa prematura), em contraposição à realidade da Universidade do Rio de Janeiro, confiando à Faculdade de Ciências e Letras o papel de promotora de pesquisas científicas de caráter desinteressado (BONTEMPI Jr., 2017).

No Rio de Janeiro, em agosto de 1927, a questão da organização do sistema universitário foi objeto de debate no Congresso do Ensino Superior, promovido pela Faculdade 
de Direito do Rio de Janeiro, como atividade das comemorações do centenário da fundação dos cursos jurídicos no país. Em cinco dias de discussões sobre o tema foram apresentadas as teses pelos colaboradores, entre eles membros da $\mathrm{ABE}$, como respostas ao questionário desenvolvido pela comissão organizadora. As questões versavam, entre outros pontos, sobre o tipo de universidade que deveria ser adotado no país, os quesitos necessários e os lugares apropriados para tal instituição, sua natureza jurídica, a existência de institutos de pesquisa e as formas de desenvolver o "espírito universitário”, aspecto que segundo os debatedores não existia de fato na Universidade do Rio de Janeiro. Para criar a instituição universitária, seria preciso unir, por epigênese, pelo menos duas faculdades profissionais, acrescentando-se uma faculdade de letras e outra de ciências e altos estudos (CAMPOS, 1940, p. 295-339).

Ao final de 1928, sob a liderança de Ferdinando Labouriau e à luz do inquérito produzido pelo OESP, a ABE lançou o Inquérito sobre o problema universitário, promovido pela Seção de Ensino Técnico e Superior, composto majoritariamente por engenheiros da Escola Politécnica do Rio de Janeiro, a partir das contribuições de teses apresentadas na Segunda Conferência Nacional de Educação, realizada em Belo Horizonte naquele ano, em especial as desenvolvidas por Tobias Moscoso, primeiro reitor da URJ, em seu estudo "Sobre o problema universitário”. A iniciativa do inquérito sobre o ensino universitário teve ampla adesão de intelectuais e da imprensa, especificamente de Julio de Mesquita Filho em São Paulo, Mendes Pimentel em Minas Gerais e Bernardino de Souza na Bahia, com cobertura em $O$ Jornal e $O$ Estado de S. Paulo. Iniciado com um documento contendo uma síntese de ideias que serviriam de partida para a discussão do problema, o inquérito foi organizado por temas desenvolvidos por Ferdinando Laboriau, Roquette Pinto, Vicente Licínio Cardoso, Raul Leitão da Cunha, Inácio Azevedo do Amaral e Domingos Cunha. Em 1929, o documento original com as diretrizes da seção foi reeditado, tendo-se acrescentadas à base inicial as respostas ao inquérito da ABE e ao inquérito promovido em 1926 pelo OESP (CARVALHO, 1998, p. 258-259).

Conforme afirma Carvalho (1998), a concepção de universidade predominante na Seção de Ensino Técnico e Superior da ABE pode ser encontrada nas respostas apresentadas por Amoroso Costa, Tobias Moscoso e Álvaro Ozório de Almeida, junto ao pensamento dos líderes Vicente Licínio Cardoso e Ferdinando Laboriau. De forma estrutural, os organizadores do inquérito orientavam-se por uma visão nacionalista da função universitária. Retomando o 
pensamento de Vicente Licínio Cardoso, a universidade deveria ser concebida como "usinas mentais” e "focos de brasilidade”, local onde “pensar o Brasil” seria o objetivo para criar uma “consciência nacional”. A pesquisa científica seria o instrumento para o exercício de pensar a nacionalidade e formar uma "mentalidade” de interesse público. Apesar de defenderem a criação de uma instituição voltada às questões nacionais, os pensadores eram críticos à fundação de um modelo universitário único ao país, pois cada universidade deveria resolver os problemas de sua área de influência. A "mentalidade" de interesse público, nascida no seio da universidade, deveria ser levada aos outros membros da sociedade por meio do serviço de “extensão universitária”, aos moldes defendidos por Laboriau, assim como a própria ABE vinha promovendo, desde 1926, por meio de cursos de alta cultura e conferências de uma variedade de assuntos, ministrados por professores e especialistas de variadas instituições. Este serviço também cumpriria a importante função de criar o "espírito universitário", por meio da aproximação entre os professores e alunos das diversas escolas. Porém, a concepção de universidade predominante na Seção de Ensino Técnico e Superior não era unânime na entidade. A oposição a esse grupo pode ser representada por Barbosa de Oliveira, membro do Conselho Diretor. Em resposta ao inquérito, Oliveira defendia a impossibilidade de criação de universidades sem primeiro efetuar alterações no ensino secundário, buscando a formação paciente e gradativa da elite que cursaria o ensino superior. Por fim, era partidário do ensino superior voltado às escolas profissionais, as “universidades industriais”, pois o "tipo científico" ainda seria prematuro para o país. Este argumento não foi, tampouco, exclusivo aos membros da ABE. Ele apareceu como força de oposição em outras instâncias de debate sobre a criação de universidade, como no Rotary Club de São Paulo.

Vale ressaltar que entre os dois inquéritos e o relatório do congresso existiram diferenças substanciais. O documento promovido pelo OESP constituiu um texto orgânico, representativo das bases da política educacional da Comunhão paulista. Já o questionário promovido pela ABE e o relatório do Congresso do Ensino Superior foram mais abrangentes e heterogêneos, não mantendo uma unidade de pensamento sobre a questão universitária por representarem de fato o embate de ideias entre diferentes grupos que se propunham a discutir a universidade no Brasil (CUNHA. 1980, p. 203). Para Cardoso (1982, p. 52-54), a matriz ideológica do inquérito da $\mathrm{ABE}$ e de $O E S P$ eram diversas, pois enquanto no primeiro a universidade era concebida como local de formação da nacionalidade, no segundo caso o foco estava voltado para o estado, 
representado pela Comunhão paulista liderando o projeto de desenvolvimento da nação por meio de sua hegemonia política e cultural. Para além da diferença em relação ao enfoque dado à questão da nacionalidade, destacamos outro ponto primordial: a criação dos institutos de altos estudos. Na concepção do grupo paulista, era necessária a criação da faculdade de filosofia, algo que não foi apontado nos outros documentos, os quais os debatedores centravam-se na criação de faculdades de letras e de ciências como centro de altos estudos. Apesar de parecer uma pequena nuance ou mesmo um sinônimo, a diferença de nomenclatura em relação à qual faculdade seria o local de formação dos estudos desinteressados representa a diversidade de concepções de universidade e posicionamentos institucionais dos intelectuais envolvidos no amplo movimento pela criação de uma “verdadeira universidade” e dá relevo a uma especificidade do projeto de universidade paulista. Em outros termos, evidencia uma diferença nas apropriações dos modelos universitários, notadamente entre o francês, o alemão e o norte-americano, que está calcada na própria matriz de pensamento da área de saber pela qual os intelectuais estavam engajados: para o "grupo do Estado”, chefiado por bacharéis, a faculdade de filosofia à maneira francesa era central, pois era a representação do pensamento liberal e carregava consigo o conceito de ciência desinteressada; já para os engenheiros e médicos, o pilar dos estudos desinteressados estava na faculdade de ciências, destaque do modelo alemão e americano, local da pesquisa experimental e laboratorial, feita em busca da ciência pura como contraposição ao imediatismo técnico e profissional.

“Todas essas propostas a respeito da organização do ensino superior no Brasil, no sentido da criação de universidades, de 'verdadeiras universidades’ [...] constituíram um conjunto complexo e contraditório”, que somente iria se destacar nitidamente após a Revolução de 1930 (CUNHA, 1980, p. 203). A incompreensão da complexidade de concepções de universidade e mesmo das especificidades de quais e como seriam os institutos responsáveis pelos estudos científicos pode levar a uma avaliação parcial do movimento pela universidade em São Paulo, centralizada na visão de universidade defendida pelo "grupo do Estado". No entanto, os debates promovidos fora das páginas de OESP constituíram importantes espaços de disputa sobre o projeto da universidade, que ecoaram vozes tanto perpetuadas quanto ocultadas ou submetidas com o decreto de criação da USP no formato desejado pelo "grupo do Estado", posteriormente contestado internamente por representantes das faculdades pré-existentes.

Entre esses espaços, destacamos a Faculdade de Medicina de São Paulo e o Rotary Club 
de São Paulo, onde Ernesto de Souza Campos atuou, ao lado de outros entusiastas, na campanha pela universidade paulista. Particularmente, Souza Campos manteve aproximação com a concepção universitária vigente na Seção de Ensino Técnico e Superior da ABE, por meio do contato e afinidade de pensamento com Álvaro Ozório de Almeida, que igualmente era pesquisador na área médica. De toda forma, questões seminais sobre o tipo de universidade, a formação do "espírito universitário", da "consciência nacional” e a criação das faculdades de pesquisas "puras e desinteressadas" circulavam nos debates de diversas instâncias e nos inquéritos, o que constituiu entre os intelectuais envolvidos, tanto organizadores quanto colaboradores e entusiastas, um ambiente de discussão de projetos de educação superior e de nação.

\subsubsection{A questão universitária na Faculdade de Medicina de São Paulo}

Na capital paulista, a imprensa propagava o movimento pela universidade, pautando o debate público do assunto e registrando o intercâmbio de ideias e de pensadores entre a capital federal e os centros acadêmicos bandeirantes. Em visita a São Paulo, em maio de 1929, Bruno Lobo, microbiologista da URJ e colaborador do Inquérito da ABE, afirmou:

É evidente que S. Paulo muito se preocupa com o ensino superior e com a futura organização universitária. Sua imprensa acadêmica, ou diária, está quotidianamente a focalizar o assunto, publicando numerosos trabalhos que bem revelam a inquietação do meio. Aqui não se pensa, como já foi dito em outros pontos do Brasil, que a Universidade implica, apenas, na união das diversas Faculdades em um único local, em edifícios proximamente situados. A classe acadêmica paulista de há muito que se impregnou do espírito universitário, graças ao qual os centros de estudantes do Brasil agem nas questões importantes e de interesse básico com uma única vontade. Está, portanto, em via de efetivação a fundação da nova Universidade de S. Paulo ${ }^{77}$.

Em junho daquele ano, a “campanha pela Universidade” em São Paulo contou com a palestra do professor fisiologista da Universidade do Rio de Janeiro Álvaro Ozório de Almeida, presidente da Secção de Ensino Técnico e Superior da ABE em 1927. Foi promovida a convite do Centro Acadêmico Oswaldo Cruz da Faculdade de Medicina de São Paulo, naquela ocasião

\footnotetext{
${ }^{77}$ ENSINO universitário no Brasil, 5 de maio de 1929 [Fundo Ernesto de Souza Campos, Curriculum Vitae, Vol. I].
} 
presidido por Paulo de Toledo Artigas, genro de Souza Campos ${ }^{78}$. O conteúdo da conferência de Ozório de Almeida constitui importante indício dos principais pontos do debate sobre a questão no ambiente da Faculdade de Medicina de São Paulo, em ligação com a campanha da $\mathrm{ABE}$ e de OESP. Logo após à conferência proferida no Centro Oswaldo Cruz, os médicos paulistas Geraldo de Paula Souza e Ernesto de Souza Campos protagonizaram a discussão sobre o tema do ensino universitário no Rotary Club de São Paulo, tornando públicas suas respectivas teses sobre a problemática universitária.

De acordo com Souza Campos (1940, p.353-354), Ozório de Almeida era "grande conhecedor da vida universitária no país e no estrangeiro”, com diversos trabalhos publicados sobre o tema. O fisiologista já teria ido a São Paulo, em 1927, para expor suas considerações sobre as organizações universitárias e retornava para discorrer sobre suas "Reflexões sobre a organização das Universidades”, texto que foi publicado na íntegra pelo jornal O Estado de S. Paulo. Conforme declarou em entrevista, Ozório de Almeida, junto com outros membros da ABE, viajava em campanha para “despertar a atenção do país sobre o problema”, que em seu entendimento não poderia ser resolvido sem um "estudo profundo e consciencioso do assunto". Com sua série de conferências, pretendia “fazer barulho” sobre a questão e “agitar a opinião do país” para que a população saísse do estado de apatia sobre uma das questões nacionais mais sérias: o problema universitário.

Reafirmando a necessidade de criação de universidades em São Paulo e em todo o território, Ozório de Almeida defendia que este seria o "único caminho para a emancipação intelectual do Brasil e seu principal instrumento de progresso”, pois elas serviriam como "laboratório em que se geram os espíritos componentes e ativos que vão imprimir à sociedade a sua força de evolução” (CAMPOS, 1940, p. 355). Sendo assim, a questão mestra era perguntar qual tipo de universidade se deveria criar, já que existia uma imensa variedade de universidades pelo mundo. Em sua opinião,

só são eficientes as Universidades que cultivam o espírito científico, que dele se acham impregnadas, e com ele impregnam a mocidade até aos últimos refolhos da alma, criando-lhes uma nova consciência, e no mundo prático, uma moderna forma de bom senso. A essência de uma Universidade, digna desse nome, a sua razão de ser é a criação, o desenvolvimento, a propagação, a transmissão do espírito científico

\footnotetext{
${ }^{78}$ Paulo de Toledo Artigas era casado com uma das filha de Emesto, Maria de Souza Campos Artigas.
} 
(Almeida apud CAMPOS, 1940, p. 355).

Nas considerações feitas em conferência anterior e que constam como resposta ao inquérito da $\mathrm{ABE}$, o professor apresentou a universidade alemã e a norte-americana como modelos possuidores do espírito científico, locais onde “espíritos utilitários”, ou seja, das faculdades profissionais e técnicas e "espíritos idealistas”, das faculdades de ciências e letras, promovem juntos o progresso da nação.

Na América do Norte, a associação de todos esses elementos de tendências variadas, forma como na Alemanha, um conjunto harmônico que constitui verdadeiramente a Universidade. Assim, longe de se oporem, essas tendências diversas se completam (ALMEIDA, 1929, p. 150).

Esta concepção vai ao encontro da apresentada na conferência feita em 1929, quando sua resposta para o tipo de universidade que o Brasil deveria implantar era a "Universidade enciclopédica, na qual quem quer que seja deve poder estudar o que quer que seja”, cumprindo a finalidade de instruir os alunos no espírito científico, na formação profissional, na preparação de professores e na extensão dos conhecimentos (CAMPOS, 1940, p. 355-356).

Outro ponto em destaque na argumentação de Ozório de Almeida era sua concepção a respeito da organização interna da universidade por matérias, ou seja, o agrupamento de todo o pessoal, material e biblioteca em um mesmo edifício, constituindo assim um instituto, departamento ou seção específica de cada área do saber. Desta maneira, evitar-se-ia a dispersão dos pesquisadores e dos recursos necessários para as pesquisas científicas e a universidade cresceria pela adição de novas cadeiras. A evolução deste pensamento desembocava na compreensão de que

dentro dessa organização, do mesmo modo que se agruparam os especialistas de maneira a facilitar-lhes o trabalho, assim também se poderia agrupar as matérias afins em escolas de Ciências para as ciências atualmente separadas nas escolas profissionais de Letras, de Medicina, Engenharia, estas para as cadeiras de aplicação média de engenharia, etc. Não há nenhum inconveniente, antes apresenta algumas vantagens pela aproximação e auxílios mútuos dos professores (CAMPOS, 1940, p. 358).

A questão da criação da faculdade de Ciências era um dos pontos nevrálgicos das arguições sobre o sistema universitário, pois para muitos pensadores este era o diferencial que lhe dava a natureza de uma verdadeira organização universitária. Até aquele momento, o ensino 
superior estava voltado para a formação profissional, concentrado especialmente nas faculdades de Medicina, Direito e Engenharia. Essa característica histórica da formação do ensino superior nacional foi apontada pelos contemporâneos de Souza Campos, que compreendiam os desafios propostos para a formação do sistema universitário perante as existentes unidades de formação superior. Como solução ao problema da justaposição dos institutos profissionais sem uma conexão que os unisse -- ou seja, o “espírito universitário” ou a “consciência científica” --, Ozório de Almeida e, mais adiante, Souza Campos defendiam a concentração das cadeiras de ciências fundamentais pré-existentes nas faculdades profissionais em uma faculdade, a Faculdade de Ciências. Este tema seria, na década de 1930, após a formação da Universidade de São Paulo e do estabelecimento da Faculdade de Filosofia, Ciências e Letras como a alma mater da universidade, o motivo de uma verdadeira batalha protagonizada por Souza Campos, como diretor da FFCL, contra a congregação da Escola Politécnica (BONTEMPI Jr., 2001; CELESTE FILHO, 2009).

Ozório de Almeida teceu considerações a respeito da organização espacial da universidade, elemento importante para promover o contato entre alunos, professores e as diversas áreas do saber, fator indispensável à formação do "espírito universitário”. Para o professor,

torna-se absolutamente necessário reunir as atuais escolas em um mesmo terreno, de modo a tornar íntimo o contato entre os estudantes e professores de estudos diferentes. Os resultados de uma tal medida são inúmeros e importantíssimos. Assim haveria uma grande economia na manutenção e organização da Universidade, evitando-se a formação de múltiplos laboratórios iguais, bibliotecas incompletas. [...] Quanto ao contato de alunos de várias especialidades e a possibilidade para eles de seguirem cursos fora do programa de seus estudos, serve para alargar o espírito de cada um, tornar melhor conhecidas as outras profissões, retificar as próprias ideias e alargar os horizontes de todos os espíritos, evitando o que acontece entre nós, a ignorância recíproca que apresentam os médicos, engenheiros, advogados, comerciantes, veterinários, agricultores, etc. etc. Com tal concentração, a pesquisa científica torna-se mais fácil, pois que nunca um pesquisador verdadeiramente original e superior prescindirá dos inúmeros conhecimentos de especialistas em outras ciências, com os quais aprenda as questões que sozinho não pode resolver.

As considerações de Ozório de Almeida sobre o tipo de universidade, o "espírito científico”, a concentração das cadeiras em unidades de afinidade e estas unidades em um mesmo espaço universitário foram aspectos que Ernesto de Souza Campos se apropriou, 
abordou e defendeu publicamente em sua trajetória no debate e na organização do ensino superior em São Paulo, notadamente em congruência com o posicionamento do professor da URJ. Esta aproximação com aspectos do modelo norte-americano de universidade não foi casual. Naqueles tempos, a inspiração de elementos da ciência médica norte-americana (com suas apropriações do modelo alemão) e, consequentemente do ensino superior norte-americano, já era uma realidade no campo médico, como na Faculdade de Medicina de São Paulo, conformada pelo modelo Rockefeller. Portanto, havia uma boa razão para que as teses defendidas por Ozório de Almeida ressoassem na instituição médica paulista e encontrassem apoio e seguidores, como Souza Campos.

O arremate da ascensão de Ernesto de Souza Campos como conhecedor da causa universitária no ambiente da faculdade foi por meio da publicação, no segundo semestre de 1929, do artigo “Considerações sobre o problema universitário” na Revista de Medicina, periódico do Centro Acadêmico Oswaldo Cruz. Na seção editorial Chronica, a revista anunciava

\begin{abstract}
em seu número presente a colaboração de um dos professores da Escola Médica de São Paulo que maior interesse tem mostrado pelos assuntos universitários, tão dos acadêmicos e, infelizmente, ainda muito pouco considerados por grande número, que, não raras vezes, demonstram não ter deles as mais corriqueiras noções. Solicitando a colaboração do Prof. Souza Campos, a redação da "Revista de Medicina" tem a certeza de estar caminhando ao encontro dos desejos dos estudantes interessados pelos problemas escolares e estará, também, prestando a sua quota de auxílio para a generalização das ideias universitárias, que só muito recentemente têm sido explanadas de modo amplo entre nós (CENTRO ACADÊMICO OSWALDO CRUZ, 1929, p1).
\end{abstract}

Souza Campos, herdeiro de Ozório de Almeida na campanha pela universidade na Faculdade de Medicina de São Paulo, manteve viva a “centelha de entusiasmo”, iniciada pelo médico da $\mathrm{ABE}$ entre os estudantes paulistas e deu sequência a sua obra, ampliando os espaços de debate e de atuação da classe médica paulista sobre o tema universitário.

\title{
3.3.3 O debate sobre a universidade no Rotary Club de São Paulo
}

Em meados de 1929, Souza Campos apresentou-se à opinião pública como mais um expert sobre o problema universitário, unindo-se ao movimento pela universidade de São Paulo 
por meio dos embates no Rotary Club de São Paulo ${ }^{79}$. Nesse espaço, Souza Campos partilhou e combateu argumentos a respeito da organização universitária com outros intelectuais e definiu os princípios defendidos em sua atuação no debate público e em instâncias institucionais. Na grande imprensa, Souza Campos conquistou progressivamente destaque com seu posicionamento e atuação em iniciativas voltadas ao tema universitário como a criação da Casa do Estudante e da Associação dos Antigos Alunos da Faculdade de Medicina.

O tema da organização universitária foi introduzido como debate na associação por Geraldo de Paula Souza, em julho de 1929. No início daquele mês, fora empossada uma nova diretoria, na qual Theodoro Ramos, igualmente defensor da causa e futuro fundador da Universidade de São Paulo, foi eleito presidente. Em sua oração, Paula Souza defendeu a universidade como local de "despertar o gosto da investigação ou da pesquisa original nos diferentes ramos da ciência”. Para tanto, se deveria pleitear a "fundação de dois institutos modelares, uma faculdade de filosofia e letras e uma faculdade de ciências”. Porém, de imediato, a união das faculdades pré-existentes seria o indicado, homogeneizando seus fins nos

\footnotetext{
${ }^{79}$ Conforme Setton (2004), o Rotary Club constitui uma entidade civil internacional denominada como clube de serviço ou organização voluntária, criada no ano de 1905, em Chicago, nos Estados Unidos, por iniciativa de quatro profissionais liberais e idealizada pelo advogado Paul Harris, como forma de manterem contatos de auxílio mútuo e de companheirismo, frente a uma cidade em crescente urbanização e insegurança, fadada ao anonimato das multidões. No Brasil, o primeiro clube foi fundado no Rio de Janeiro, em 1922, por empresários e autoridades governamentais. No entanto, a maior parte dos membros atuais são de homens que ascenderam à classe média por meio do capital cultural adquirido na escola e pelo consequente posicionamento no mercado profissional. Para a autora, os clubes rotários funcionaram e funcionam como espaços de sociabilidade, local de aquisição e reafirmação do capital social e simbólico ligada ao habitus burguês. Fundada com o objetivo de promover benefícios profissionais, a entidade passou a ter como foco a moral do serviço ao próximo, o que lhe concedeu, por meio do engajamento de seus indivíduos, um status de promotora do bem estar social, sentimento que dá significado e utilidade à vida dos membros da entidade e corresponde à prática da filantropia, cara à cultura norte-americana. De acordo com Uhle (1991), a filantropia rotária tem como característica ser de "socorro útil", ou seja, que trabalha no campo moral ao invés do material, tutelando e investindo em áreas como a educação e a saúde, pois os rotarianos, elite esclarecida, se colocam no papel de redentores da sociedade em busca de sua harmonização. O Rotary Club de São Paulo, criado em 1924, é considerado como centro de referência para o país pelo porte político e econômico de seus associados e pela influência de suas obras. Entre elas estiveram iniciativas de criação e manutenção de escolas e projetos voltados à educação, assistência, higiene e saúde da camada popular, assim como dos debates em torno da criação da universidade em São Paulo, voltada à elite. Em nossa perspectiva, buscamos identificar as diferentes vozes que estiveram representadas nos debates sobre o ensino superior nas reuniões rotárias entre 1929 e 1930, compreendendo suas filiações com as instituições e projetos de educação superior na capital paulista. No acervo pessoal analisado, encontramos uma lista dos sócios de 1929, na qual podemos identificar um número expressivo de professores do nível superior, a título de amostra: Theodoro Ramos, Victor da Silva Freire, Luiz Anhaia Mello, Francisco E. da Fonseca Telles e Alexandre Albuquerque, da Escola Politécnica; José Joaquim Cardoso de Melo Neto e Reynaldo Porchat, da Faculdade de Direito; Geraldo de Paula Souza, Emesto de Souza Campos, Cantídio de Moura Campos, Benedicto Montenegro, Antônio de Almeida Prado, da Faculdade de Medicina. Além dos professores, destacamos os nomes de José Carlos de Macedo Soares, figura importante na carreira de Souza Campos pela indicação à direção da Faculdade de Medicina, em 1930, e de Plínio Barreto, bacharel e jornalista, membro do "grupo do Estado". Rotary Club de São Paulo, 1929 [Fundo Ernesto de Souza Campos, Curriculum Vitae, Vol.II] .
} 
pontos possíveis, resguardando a autonomia didática e administrativa de cada unidade ${ }^{80}$. Para Souza Campos, em relato feito no livro Educação Superior no Brasil, publicado em 1940, Geraldo de Paula Souza propunha a criação de uma universidade para a formação das elites. Por isso, o número reduzido de alunos, a adoção do tempo integral de dedicação dos professores e o bom aparelhamento dos laboratórios e bibliotecas eram imprescindíveis, como fora implantado na Faculdade de Medicina, com a adoção do modelo Rockefeller. A universidade não deveria ser uma justaposição administrativa das escolas superiores, mas um organismo que crescesse gradualmente a partir de sua base de organização, "lacuna” a ser preenchida urgentemente no ensino nacional: a escola de formação de cultura geral. Quanto ao modelo universitário, não deveriam ser copiadas ou transplantadas organizações de países estrangeiros (CAMPOS, 1940, p.362).

Como objeção à fala de Paula Souza, Rodolpho Nogueira argumentou não achar razoável pensar em universidade se o ensino secundário ainda era inexistente e se o país estava repleto de analfabetos. Em sua visão, se deveria primeiramente cuidar de alfabetizar e de melhorar o ensino secundário, para depois se pensar em universidades ${ }^{81}$. Após lançar acusações “fulminantes” contra o sistema escolar, as palavras de Rodolpho Nogueira teriam deflagrado uma "saraivada de apartes". Em defesa do ensino superior pronunciou-se Fonseca Telles, argumentando que seriam das universidades que se formariam professores capazes para o ensino secundário. Ao lado de Fonseca Telles, replicaram as falas de Nogueira os rotarianos Leão Pinto Serva, José Augusto de Magalhães, Paulo de Moraes Barros, Waldemar Ferreira, Ernesto de Souza Campos e Heribaldo Siciliano. Nesse momento, Souza Campos propôs a nomeação de uma comissão especial para o estudo do problema universitário, com o intuito de coligirem subsídios e dados em torno da questão, aplicáveis às necessidades de São Paulo. Theodoro Ramos designou, incluindo-se nesse grupo como presidente da comissão, os rotarianos Paula Souza, Souza Campos, Cardoso de Mello Netto, Plínio Barreto e Fonseca Telles ${ }^{82}$.

\footnotetext{
${ }^{80}$ ROTARY Clube de São Paulo, 20 de julho de 1929 [Fundo Ernesto de Souza Campos, Curriculum Vitae, Vol. I].

${ }^{81}$ Conforme apontou Carvalho (1998), a discussão entre intelectuais sobre a prioridade de desenvolver o ensino secundário ou o ensino superior perpassou igualmente os embates dos grupos sediados na ABE e constituiu uma relevante questão educacional no período.

${ }^{82}$ ROTARY Clube de São Paulo, 20 de julho de 1929 [Fundo Ernesto de Souza Campos, Curriculum Vitae, Vol. I]. Embora não conste nesta reportagem, Reynaldo Porchat, futuro primeiro reitor da USP, também fez parte da comissão nomeada pelo presidente do Rotary Club. Interessante destacar a presença de Plínio Barreto na
} 
Na sessão seguinte, Souza Campos retomou a questão e apresentou a comissão especial encarregada do assunto. Para ele, a comissão, ao reunir e debater as informações pertinentes à organização do ensino superior, criaria um trabalho de "inestimável valor e utilidade”, sendo possível que dali saísse um "esboço das linhas gerais que servirão de base para a discussão do modelo mais conveniente para a futura universidade de S. Paulo”. Expressando sua opinião a respeito da contenda anteriormente deflagrada sobre o ensino secundário e o ensino superior, Souza Campos defendia a existência de um “curso intermediário” entre os dois níveis, futuro núcleo dos institutos de ciências e letras da universidade, que seria oportunamente unido às escolas profissionais ${ }^{83}$. Esse curso supriria a lacuna deixada pelo ensino secundário, pois proporcionaria os estudos das disciplinas fundamentais com base científica e, ao mesmo tempo, centralizaria o aparelhamento destinados às tais disciplinas, que até então se encontravam desdobrados nos diversos cursos profissionais ${ }^{84}$.

Em agosto, o tema universitário continuou sendo objeto de discussão entre os rotarianos. Victor da Silva Freire ${ }^{85}$ entrou em desacordo sobre o tipo de universidade defendido pelos médicos Paula Souza e Souza Campos. Em sessões subsequentes, intercedeu, com base no histórico de outros países, por uma concepção de universidade como local de formação pragmática, de ensino voltado à preparação dos líderes do progresso industrial, de caráter essencialmente profissional. Para Silva Freire, a universidade serviria para a formação dos grandes chefes administradores das empresas nacionais (CAMPOS, 1940, p. 362-363).

Apesar de Souza Campos (1940, p.363) afirmar que a concepção de universidade comissão, provavelmente por seu status como elemento do "grupo do Estado", como forma de manter uma
conexão entre a "campanha pela Universidade” do jornal e o debate no Rotary. No entanto, para Cardoso (1982,
p. 66), o "inquérito" do Rotary Club teve pequeno destaque em OESP e não foi incorporado como parte da sua
campanha, provavelmente pela heterogeneidade dos depoimentos. Tal afirmação corrobora a hipótese de que
existiam diferentes visões acerca do formato da universidade em São Paulo, caracterizando um campo de debate
mais complexo do que o que envolvia diretamente na campanha encetada pelo jornal.
83 Mesmo sem podermos afirmar, por falta de registros documentais, que a argumentação de Souza Campos teve
ressonância, a ideia de "curso intermediário" acabou sendo implantada à criação da universidade no formato do
Colégio Universitário, que funcionaria com programas discutidos pelas congregações da instituição e
regulamentado pelo Conselho Universitário, com base nos Estatutos das Universidades Brasileiras, de 1931 .
84 Diário de S. Paulo. A sessão semanal de hontem do Rotary Clube de S. Paulo, 27 de julho de 1929 [Fundo
Ernesto de Souza Campos, Curriculum Vitae, Vol. I].
85 Victor da Silva Freire foi professor e diretor da Escola Politécnica, formado em engenharia civil pela École
Nationale des Ponts et Chaussées, na França, em 1891 . Tendo iniciado sua carreira na Europa, foi convidado a
retornar ao Brasil por Campos Salles, em 1895, assumindo cargos de comando do sistema de saneamento
paulista. Além do trabalho no setor público, atuou em várias companhias e organizações. Em 1898, iniciou a
carreira docente, lecionando na cadeira de Tecnologia Civil e Mecânica, exercendo a diretoria entre 1933 e
1934 (ESCOLA POLITÉCNICA, 2017b). 
externada por Silva Freire estava em “posição muito diversa de que é geralmente admitida pelos estudiosos do assunto”, esta não era, tampouco, uma idiossincrasia. A ideia de educação voltada aos interesses industriais estava bem representada dentro do Rotary Club e em outras instituições pelos adeptos dos métodos científicos de racionalização da produção e do trabalho ${ }^{86}$. Roberto Simonsen e Roberto Mange foram pilares de iniciativas que visavam a introdução dos métodos tayloristas e fordistas nas fábricas e nos espaços de formação profissional. Por trás desse objetivo estava a convicção de que o controle social (entendido como harmonização da sociedade) e a prosperidade econômica somente seriam possíveis por meio da administração científica do trabalho, liderada pelos engenheiros e administradores. De acordo com Weinstein (2000, p.40),

a filosofia fordista apresentava a fábrica como um modelo para toda a sociedade e considerava a burguesia industrial, aliada a um corpo de gerentes tecnicamente competentes, a classe mais capacitada para cumprir o dever cívico de uma elite moderna, dada a sua competência técnica e sua posição estratégica no campo da produção.

O embate, polarizado entre a comissão especial e Silva Freire, intensificou-se em setembro. Souza Campos rebateu os argumentos advogados por seu opositor, especialmente sobre os tipos de universidades estrangeiras. Para tanto, discorreu sobre a história das universidades, atentando especialmente sobre as críticas feitas a universidade norte-americana. Em sua fala, Souza Campos colocou-se ao lado dos conhecedores do assunto, dos homens que deveriam de fato debater e propor soluções para o problema universitário, estando entre eles os membros da comissão especial, inspirados pelos colaboradores dos inquéritos da ABE e de OESP. Após historiar sobre a formação universitária de alguns países usando o arcabouço teórico reunido em suas viagens ao estrangeiro, Souza Campos preocupou-se em rebater as críticas de Silva Freire no tocante às universidades norte-americanas, esclarecendo qual o

\footnotetext{
${ }^{86}$ A partir de 1928, com a criação da Fundação do Centro das Indústrias de São Paulo e o rompimento com a Associação Comercial de São Paulo, os industriais paulistas passaram a disputar com maior força a hegemonia das elites econômicas. Esse grupo apoiou a candidatura de Júlio Prestes, em 1930, e aliou-se ao interventor João Alberto Lins de Barros com a queda do secretariado do Partido Democrático. Em 1931, fundaram o Instituto de Organização Racional do Trabalho, órgão privado de prestação de serviços voltados à racionalização da produção e do ensino profissional. A instituição contou com maior colaboração do governo estadual sob a interventoria de Armando de Salles Oliveira, membro fundador do IDORT, empresário e acionista de O Estado de S. Paulo. Com o advento do Estado Novo, os entusiastas dos métodos de racionalização do trabalho romperam com os políticos constitucionalistas e aproximaram-se da política varguista. Quanto à educação superior, em 1934, Simonsen e Mange colaboraram na implantação da Escola Livre de Sociologia e Política, instituição estreitamente ligada ao IDORT, com base na crença de que as ciências sociais eram fundamentais para resolver os problemas relacionados ao desenvolvimento industrial (WEINSTEIN, 2000).
} 
“espírito que deve reger a organização universitária nos tempos modernos”. Um dos pontos nodais estava no status da escola de engenharia. Segundo o estudo de Souza Campos (1940, p. 369),

as escolas de engenharia e outros institutos técnicos geralmente não fazem parte das organizações universitárias, salvo raras exceções. Só recentemente foi criado o título de engenheiro doutor que na França depende da Faculdade de Ciências [...]. É que ali ainda perdura o agrupamento histórico das quatro ou cinco faculdades e o preconceito de isolar o ensino das ciências aplicadas -- o estudo profissional -- dos estudos de ciências puras que são privilégios dos grandes centros universitários. Este é mesmo um dos traços característicos que distinguem as universidades europeias das norte-americanas em geral, a que estão, frequentemente, incorporadas as escolas de engenharia assim como outros Institutos modernos de ensino. Mais novas que as outras, desligadas de laços tradicionais seculares e modeladas segundo os tipos mais diversos, não viram inconvenientes, senão vantagens, em associar na sua maioria os dois ensinos superiores - científico e profissional, imprimindo, deste modo, a este, dentro de limites razoáveis, os métodos e processos daquele.

Conforme explicação de Souza Campos, o que teria proporcionado a mudança no caráter do ensino superior norte-americano, inicialmente constituído com base no college inglês, foi a introdução da escola de graduados (graduate school), "baseados nas faculdades de filosofia das universidades alemãs e que oferecem a mesma oportunidade para estudos avançados em artes, ciências e investigações científicas que os principais centros europeus”. Não por acaso, o exemplo dado por Souza Campos foi a Johns Hopkins. Reproduzindo as palavras do patrono da referida instituição, Souza Campos explanou: “a Universidade tem dois fins principais -- o progresso do ensino através da investigação científica de seus professores e estudantes qualificados e o aprendizado pelos seus cursos de instrução”. Dessa maneira, os pesquisadores competentes no exercício da investigação científica serviriam como guia para os que desejassem adquirir conhecimentos. O diferencial estaria na implementação do método experimental no ensino universitário, ao lado do ensino prático e teórico, cuja função seria desenvolver a "imaginação e o espírito de crítica, tão necessário ao refinamento da civilização moderna” (CAMPOS, 1940, p.370-371).

Souza Campos arremata, por fim, discutindo o tipo universitário ideal para o Brasil. Em sua visão, o tipo profissional puro, aquele defendido por Silva Freire, não caberia no conceito universitário moderno, assim como não seria cabível criar um tipo cultural puro, como eram os 
colleges ingleses, pois ambos não proporcionariam aos alunos e professores a investigação por meio do método experimental. Indo ao encontro de outros pensadores da questão universitária, Ernesto de Souza Campos advogava pelo

tipo misto, com um bom núcleo de estudos científicos e culturais desinteressados que irá crescendo gradualmente, pela justaposição de novas peças, até atingir o valor das faculdades de filosofia ou ciências e letras ou artes liberais, sistema completado pelas escolas profissionais que possuam elevada organização científica e capacidade para desenvolver pesquisas originais, aparelhamento este indispensável para manutenção destes institutos no alto nível que lhes compete (CAMPOS, 1940, p.374).

Dessa maneira, a cultura universitária deveria ser desenvolvida em todas as direções do saber, como no caso do tipo universitário norte-americano,

dentro do espírito científico, cuidando, especialmente, de desdobrar, cada vez mais, o ensino desinteressado, no domínio das ciências, das letras, das artes e da investigação original, essência esta que lhe dá valor próprio pela sua força criadora em desvendar novos conhecimentos, contribuindo assim para o progresso do saber humano (CAMPOS, 1940, p. 373-374).

Mesmo não explicitando sua defesa pelo tipo norte-americano de universidade para o Brasil, as características argumentadas por Souza Campos o levam a sugerir a apropriação de elementos desse modelo, classificado por ele como misto. Este seria o paradigma ideal, pois encaixava-se perfeitamente nas condições nacionais -- união das escolas profissionais pré-existentes -- junto à criação de núcleos de ensino e pesquisa desinteressados, voltadas diretamente à investigação científica pura e à formação do “estado moral da nação”, tão necessários ao momento de regeneração nacional. Outra questão importante a destacar é que naquele momento, tanto Geraldo de Paula Souza quanto Souza Campos defendiam a criação da universidade com os institutos superiores já existentes, com a nuance de unir em um núcleo as cadeiras de pesquisas desinteressadas, ou seja, aquelas devotadas aos estudos científicos espalhadas pelas unidades profissionais, que dariam origem à faculdade de filosofia, ciências e letras.

Embora existisse um forte grupo no clube rotário de apoiadores da universidade como local da investigação científica e da criação do "espírito universitário”, baseado no núcleo das ciências puras, a defesa do ensino profissional continuou em pauta, com a palestra sobre 
inovações da área, feita pelo convidado Roberto Mange ${ }^{87}$, professor da Escola Politécnica, apresentando argumentos que reforçavam o posicionamento de Silva Freire. Para este último, a elite intelectual teria a missão de "ver as coisas com precisão", dirigindo o trabalho, a sociedade e os interesses públicos. Em seu último parecer, voltou a defender o ensino secundário como o primordial a ser pensado no momento, pois estava diretamente relacionado às necessidades reais da nação. ${ }^{88}$

Embora os debates sobre a questão universitária não terem resultado em unanimidade e nem apresentado um documento com definições da entidade sobre o assunto, a reprodução das discussões e dos argumentos dos comentadores na grande imprensa levou o episódio ao conhecimento da opinião pública paulista. Desta maneira, Souza Campos teve seu nome inserido no rol dos entendidos sobre o ensino universitário, e aproveitando esse "trampolim”, passou a atuar, com consentimento e apoio de seus pares no âmbito acadêmico, em ações pela criação da universidade. Entre elas constam a criação da Casa do Estudante em São Paulo e a fundação da Associação dos Antigos Alunos da Faculdade de Medicina.

\subsubsection{Iniciativas rumo à universidade}

A criação da Casa do Estudante Brasileiro foi um projeto civil inicialmente organizado no Rio de Janeiro, que visava à fundação de um centro de apoio e moradia aos estudantes de ensino superior, com intenção de ser reproduzido pelos outros estados brasileiros. A embaixadora da iniciativa era a poetisa carioca Anna Amelia Carneiro de Mendonça, responsável por visitar o Rotary Club de São Paulo, em dezembro de 1929, para discutir a formação de uma comissão para engendrar uma campanha pela aquisição dos recursos para o

\footnotetext{
${ }^{87}$ Roberto Mange (1855-1955) era suíço, e havia se formado em engenharia na Escola Politécnica de Zurique. Em 1913, passou a lecionar na Escola Politécnica de São Paulo, onde fixou carreira e passou a atuar no campo acadêmico paulista, especialmente com a proposição da racionalidade científica aplicada na formação do trabalhador da indústria. A partir de 1924, Mange defendeu a criação de uma Escola Profissional Mecânica, momento em que começou a fazer proposições no campo do ensino industrial. Atuou em instituições como o Liceu de Artes e Ofícios de São Paulo, a Escola Profissional Mecânica, o Serviço de Ensino e Seleção Profissional da Estrada de Ferro Sorocaba, o Instituto de Organização Racional do Trabalho, o Centro Ferroviário de Ensino e Seleção Profissional e o Serviço Nacional de Aprendizagem Industrial (CHAMON; GUIMARÃES, 2012). Conforme apontou Weinstein (2000, p. 46), “a partir de sua ligação com a Escola Politécnica e com os círculos educacionais progressistas rapidamente estabeleceu uma rede de contatos com intelectuais brasileiros que partilhavam de seu interesse por métodos científicos”. Entre eles estavam Lourenço Filho e Geraldo de Paula Souza, que trabalharam diretamente com Mange nos projetos implantados no IDORT.

${ }^{88}$ O Estado de S. Paulo, setembro de 1929 [Fundo Ernesto de Souza Campos, Curriculum Vitae, Vol. I.]
} 
projeto em terras paulistas. Estiveram presentes na sessão representantes do Centro Acadêmico XI de Agosto, da Faculdade de Direito e do Centro Acadêmico Oswaldo Cruz, da Faculdade de Medicina, com senhoras apoiadoras da causa e alguns professores, entre os quais figurava Ernesto de Souza Campos ${ }^{89}$.

Reavivando o espírito missionário da classe médica, foi criada a Sociedade Beneficente Acadêmica “Arnaldo Vieira de Carvalho”, que tomou para si a responsabilidade da campanha em prol da Casa do Estudante, promovendo uma semana de conferências transmitidas pela Rádio Educadora Paulista durante o início do ano de 1930, com palestra inaugural pronunciada por Souza Campos. Entre os objetivos da entidade estava não somente possibilitar os recursos materiais para estudantes necessitados, mas especialmente criar um ambiente universitário de convívio físico, moral e intelectual entre os participantes. ${ }^{90}$ Em abril daquele ano, a iniciativa tomou forma, sendo aprovados os estatutos da entidade e a diretoria provisória, com participação de Souza Campos no Conselho Deliberativo. Convergindo os objetivos da Casa do Estudante como parte do movimento em prol da universidade em São Paulo, a imprensa noticiou a ação como um avanço na questão do problema universitário, pois contava com representantes das escolas superiores oficiais e uma escola privada (curso de engenharia da Faculdade Mackenzie). Para atingir umas das finalidades da entidade -- "promover a aproximação intelectual e social entre alunos, ex-alunos diplomados e professores” -- os fundadores organizariam o "Club Universitário, centro da atividade social, [que] compreenderá diversos departamentos, criando, oportunamente, uma biblioteca, salas de reunião, de diversões, anfiteatro para sessões científicas, artísticas e literárias, um campo de esportes, etc”.

Ao mesmo tempo que se empenhava na campanha pela Casa do Estudante, Souza Campos idealizava e fundava a Associação dos Antigos Alunos da Faculdade de Medicina, em março de 1930, conjuntamente com egressos que já haviam presidido o Centro Acadêmico Oswaldo Cruz. De acordo com o noticiário, a nova entidade associativa tinha por objetivo “promover a aproximação intelectual e social e a mútua cooperação entre os médicos diplomados pela Faculdade de Medicina de São Paulo, e manter sempre vivo neles o interesse

\footnotetext{
${ }^{89}$ O Estado de S. Paulo, A Casa do Estudante, 17 de dezembro de 1929 [Fundo Ernesto de Souza Campos, Curriculum Vitae, Vol. II].

${ }^{90}$ Correio Paulistano, Casa do Estudante, 5 de fevereiro de 1930 [Fundo Ernesto de Souza Campos, Curriculum Vitae, Vol. II].

${ }^{91}$ O Estado de S. Paulo. Está fundada a Casa do Estudante de S. Paulo, 1 de maio de 1930 [Fundo Ernesto de Souza Campos, Curriculum Vitae, Vol. II].
} 
por tudo quanto se relacione com o desenvolvimento e o progresso desse estabelecimento”. Em seu programa de ação, a agremiação propunha-se a organizar informações de utilidade para os membros, promover e manter intercâmbio de ideias e relações sociais entre os associados, amparar materialmente os sócios, auxiliar iniciativas de aperfeiçoamento da educação médica e do exercício da profissão, participar de comemorações da Faculdade e auxiliar os alunos em iniciativas para melhora de suas condições materiais ${ }^{92}$. Como fundo moral, Souza Campos defendia que a organização serviria para despertar nos egressos e professores o sentimento de amor e retribuição a escola -- a alma mater, prática cultural existente nas instituições de ensino superior nos Estados Unidos ${ }^{93}$.

A entidade contou com ampla adesão dos membros da classe médica e foi apresentada à opinião pública como “uma contribuição à futura universidade paulista”. Em explícita defesa da iniciativa como ação que reforçava o movimento pela universidade, o jornal O Estado de $S$. Paulo assim a definiu:

Está ainda vivo na lembrança de todos recente movimento de opinião, em prol da Universidade de S. Paulo, que empolgou as nossas rodas intelectuais e do magistério especialmente. Essa aspiração, que se manifesta cada dia mais forte em nosso meio -- aliás como expressão de uma necessidade que se faz sentir com crescente intensidade [...] vai silenciosamente conquistando terreno e tende para a realização. É o que faz pensar o surto de certas iniciativas afins, preparatórias, e que parecem prenunciar auspiciosamente o advento da Universidade de S. Paulo, com todos aqueles inconfundíveis benefícios que só de tais instituições pode uma sociedade fruir. Conhecem os leitores o grande impulso que ultimamente vem tendo, entre nós, a "Casa do Estudante”, que já se pode contar como iniciativa vitoriosa. A esse passo, de alta significação moral e material, como preparatório do ambiente universitário, seguiu-se outro, que hoje com prazer revelamos aos leitores. Acaba de ser fundada nesta capital a Sociedade dos Ex-Alunos da Faculdade de Medicina ${ }^{94}$.

No discurso do jornal, a iniciativa de fundar uma associação dos ex-alunos deveria ser repercutida nos outros institutos de ensino superior, pois tinha como mérito criar um "ambiente especial, próprio para o nascimento de uma universidade de fato e compatível com a vida de uma instituição dessa ordem”. Em crítica ao caso da Universidade do Brasil, criada por decreto

\footnotetext{
${ }^{92}$ A ASSOCIAÇÃO dos Antigos Alunos da Faculdade de Medicina recentemente fundada nesta capital, [1930?] [ Fundo Ernesto de Souza Campos, Curriculum Vitae, Vol. II].

${ }^{93}$ ERNESTO DE SOUZA CAMPOS, Considerações gerais sobre o problema universitário, [1929?] [Fundo Ernesto de Souza Campos, Curriculum Vitae, Vol. II].

${ }_{94}$ O Estado de S. Paulo. Uma obra sympathica, 14 de maio de 1930 [Fundo Ernesto de Souza Campos, Curriculum Vitae, Vol. II].
} 
e sem preparo da comunidade acadêmica, a fundação de associações de ex-alunos seria o meio de “preparar o terreno”, de criar o “espírito universitário” entre os profissionais das escolas superiores para a futura universidade.

De fato, as duas iniciativas lideradas por Souza Campos o colocaram em posição de destaque nos círculos intelectuais paulistas, conferindo-lhe autoridade na questão do problema universitário, devido ao conhecimento e à atuação em prol da fundação da instituição em São Paulo. Em decorrência, Souza Campos chegou a ser indicado para concorrer ao cargo da presidência do Rotary Club em 1930, a que declinou por encontrar-se absorto nos trabalhos relacionados à Casa do Estudante e à Associação dos Ex-Alunos da Faculdade de Medicina ${ }^{95}$.

Concomitantemente a essas ações, Souza Campos foi convidado a realizar, em junho daquele ano, uma conferência na Sociedade de Educação ${ }^{96}$, com o tema "Educação literária e educação científica”. Naquele espaço, Souza Campos professou sua missão na defesa pela criação da universidade moderna, baseada no "espírito científico e cultural” dos estudos, ao lado dos conhecimentos aplicáveis das áreas profissionais. Instigando a atuação da sociedade organizada e dos grupos acadêmicos em prol desta obra, Souza Campos defendia que a "cultura científica e a cultura literária se complementavam” e eram “indispensáveis para a educação total do espírito”. Em consonância com os outros intelectuais paulistas que aspiravam a criação da universidade em São Paulo, Souza Campos declarava sua "profissão de fé”:

E porque esse empenho assim pertinaz, assim obstinado nesta campanha de onde há de surgir um dia -- um grande dia -- cujo sol já começa a apontar, a universidade de São Paulo constituída de todas as peças indispensáveis para formar o seu arcabouço inteiriço e harmonioso? É que, se nos cristalizou no espírito, a ideia de que só por meio dessas grandes oficinas intelectuais será possível aperfeiçoar o nosso espírito, difundindo os estudos de alto valor educativo, criando, multiplicando, propagando, divulgando a aprendizagem dos assuntos desinteressados, assim como os cursos de aperfeiçoamento e os laboratórios de investigação original que são, em essência, o elemento criador a se desdobrar em novas fontes do saber. Só nesses grandes centros é possível fazer, com a máxima eficiência, o aproveitamento integral e harmônico

\footnotetext{
95 Carta de Ernesto de Souza Campos a Manfredo Costa, 14 de maio de 1930 [Fundo Ernesto de Souza Campos, Curriculum Vitae, Vol. II]

${ }^{96}$ A Sociedade de Educação foi uma agremiação, fundada em 1922, para congregar profissionais do magistério de todos os níveis para o estudo e organização de ideias e interesses no campo educacional paulista. Reestruturada após rompimento com a campanha da ABE, a Sociedade de Educação, então dirigida pelo médico Raul Briquet, filiou-se a Federação Nacional das Sociedades de Educação, fundada por Vicente Licínio Cardoso, em 1929. Na lista de associados constavam Sampaio Dória, Fernando de Azevedo, João Toledo, Renato Jardim, Lourenço Filho, Brenno Ferraz do Amaral, José Carlos de Macedo Soares, Oscar Freire (1922-1923), Frederico V. Steidel, Roldão Lopes de Barros, Almeida Júnior, Pedro de Alcântara Machado, entre outros. (NERY, 2001). A conferência proferida por Souza Campos foi publicada na Revista Educação, periódico da Sociedade de Educação, no volume XII, número 2., fascículo 35.
} 
de todas as faculdades, disciplinando a inteligência, modelando o caráter, robustecendo o corpo, na ânsia de atingir a perfeição, o que só se consegue cultivando o amor pela ciência e despertando e dignificando os sentimentos pela arte, que imprimem na alma a verdadeira percepção do belo, em toda sua plenitude ${ }^{97}$.

Em um ato de arroubo e esperança, Souza Campos afirmou, em tom de promessa:

A Sociedade de Educação é justamente o instituto que deve tomar a si, ativamente, se já não tomou, a direção desse movimento que culminará certamente na fundação da faculdade de filosofia ou de ciências e letras, núcleo indispensável para o advento da futura universidade de São Paulo.

A concretização do desejado e debatido projeto de universidade parecia estar prestes a se realizar. A expectativa da vitória da Aliança Liberal e a implementação do programa de regeneração e reconstrução nacional via formação científica das elites criava um quadro de entusiasmo entre os intelectuais. Em outubro de 1930, Souza Campos colheu os frutos de sua ascensão no campo médico e no debate público sobre os rumos da educação paulista. Alinhado à política instaurada pelo governo provisório logo após o golpe de Getúlio Vargas, foi indicado por José Carlos de Macedo Soares, Secretário do Interior e colega rotariano, para assumir a diretoria da Faculdade de Medicina, substituindo seu amigo Pedro Dias da Silva. Entretanto, como expusemos, seu mandato durou pouco tempo, em razão do afastamento dos membros do Partido Democrático e do "grupo do Estado" do poder estadual, resultando em isolamento político e na impossibilidade de imposição de seu projeto no poder. Mesmo em um clima de instabilidade dentro e fora da faculdade, Souza Campos conseguiu entregar a obra da nova sede, o que lhe angariou louros na imprensa nacional e internacional.

A mesma sorte não teve o projeto da universidade, que ficou, com a Revolução em 1930, somente na campanha. Apesar da aparente esperança dos apoiadores da Aliança Liberal quanto à promessa do governo provisório de reforma do ensino superior ser a oportunidade para a fundação da Universidade de São Paulo, esta iria se realizar anos depois, como herdeira da Revolução Constitucionalista de 1932, encetada pelos paulistas contra o governo Vargas, e da consequente chegada de Armando de Salles Oliveira à interventoria do estado, em 1933. A reforma do ensino superior, no entanto, saiu aos moldes do governo federal, sob a orientação do ministro da Educação e Saúde Pública Francisco Campos, consubtanciada no decreto-lei n.

\footnotetext{
${ }^{97}$ ERNESTO DE SOUZA CAMPOS. Educação literária e educação científica. Separata da Revista Educação de São Paulo, 1930 [ Fundo Ernesto de Souza Campos, Curriculum Vitae, Vol. II]

${ }^{98}$ ERNESTO DE SOUZA CAMPOS. Educação literária e educação científica. Separata da Revista Educação de São Paulo, 1930 [ Fundo Ernesto de Souza Campos, Curriculum Vitae, Vol. II].
} 
19.851, promulgado em 11 de abril de 1931, nomeado de Estatuto das Universidades Brasileiras $^{99}$, condicionando a estrutura jurídica e pedagógica pela qual a Universidade de São Paulo iria ser decretada, em 1934 (CARDOSO, 1982).

3.3.5 Da revolução ao decreto: o ambiente da Faculdade de Medicina e a fundação da Universidade de São Paulo

Com a implementação da "Reforma Pedro Dias da Silva" e as adequações estruturais feitas sob as normas do EUB ${ }^{100}$, a Faculdade de Medicina consolidou, ao longo dos anos 1930, um ambiente de produção científica que contribuiu para que a instituição atingisse a condição de referência no campo médico nacional e internacional. No laboratório de Microbiologia liderado por Souza Campos, algumas figuras ganharam renome nos círculos científicos, como Zeferino Vaz, Clemente Ferreira, Flávio da Fonseca e Floriano de Almeida (MARINHO; MOTA, 2012, p.95-97). A consolidação dessa faculdade como um centro científico foi usada como instrumento de legitimação por membros da classe médica paulista, em sua luta e apoio à política de instalação de um governo liberal e “democrático”, encetados pela Aliança Liberal ${ }^{101}$. Conforme Cardoso (1982), esta agenda política passava necessariamente pela instituição da universidade, assunto que ficou em suspenso devido à ação do governo federal de centralizar as diretrizes do sistema educacional.

\footnotetext{
${ }^{99}$ As concepções básicas do projeto educacional de ensino superior do governo provisório, representadas pelas ações do ministro Francisco Campos podem ser compreendidas no conjunto dos seguintes documentos: Exposição de motivos sobre a Reforma do Ensino Superior; o decreto-lei n. 19.850, que criou o Conselho Nacional de Educação, o decreto-lei n. 19.851, que criou o Estatuto das Universidades Brasileiras e o decreto-lei n. 19.852, que tratava da Organização da Universidade do Rio de Janeiro, os três expedidos no mesmo dia (ROTHEN, 2008).

${ }^{100}$ Um dos pontos da reorganização da Faculdade foi a instituição do curso pré-médico como requisito para entrada no primeiro ano da graduação em medicina. Seu objetivo era promover ao estudante uma "adaptação didática” ao nível superior, contendo disciplinas de alemão ou inglês, matemática, física, química, história natural, psicologia, lógica história e sociologia (MARINHO; MOTA, 2012, p. 107). O curso pré-médico, de caráter complementar de instrução secundária diretamente aplicada a medicina, estava previsto pelo decreto federal n. 19.890, de 18 de abril de 1931. Tal medida assemelhava-se aos cursos preliminares existentes nos Estados Unidos, como no caso da Universidade Johns Hopkins, e remete à defesa de Souza Campos no Rotary Club pela criação de um "curso intermediário" que fizesse a ligação entre o ensino secundário e o ensino superior, preparando os alunos nas matérias de ciências básicas para a formação científica posterior.

${ }^{101}$ Ressentidos pela exclusão nos cargos de poder do estado apesar do apoio oferecido à Vargas e contrariados por sua hesitação em convocar a constituinte, os democratas paulistas iniciaram uma campanha de ataque ao interventor pernambucano João Alberto Lins de Barros, utilizando-se largamente da máquina de imprensa da qual eram filiados e proprietários. Após um período de inabilidade do interventor de constituir uma base aliada no estado, foi substituído pelo magistrado paulista Laudo Ferreira de Camargo, em julho de 1931, ato que teria amenizado, temporariamente, a influência dos tenentistas no comando de São Paulo (LOVE, 1982, p.167-168).
} 
Em 25 de julho de 1931, Antônio de Almeida Prado tomou posse do cargo de secretário da Educação e Saúde Pública, substituindo o interino da pasta, Benedicto Montenegro, em solenidade composta pela presença de grande número de médicos, docentes da Faculdade de Medicina, dos diretores do Ensino e do Ginásio da Capital e representantes do governo federal e estadual. Em discurso, Montenegro, que havia ingressado no posto de diretor do Departamento de Educação, narrou sua trajetória no cargo após o rompimento do PD com o governo provisório, elogiando a atuação de Theodoro Ramos, secretário entre fevereiro e julho de 1931, que teria se debruçado sobre a reforma do ensino, sendo responsável pelo projeto de autonomia das escolas superiores paulistas, aceito pelo governo federal. Não deixou de agradecer aos esforços do diretor da Faculdade de Medicina, Sérgio Meira Filho, que estava colaborando “com o ardor da nossa fé e com o entusiasmo de verdadeiros idealistas para o desenvolvimento da primeira Faculdade de Medicina da América do Sul”, e a Souza Campos e Rezende Puech, aos quais "coube a árdua tarefa da qual se desempenhavam de modo tão brilhante, dotando a Faculdade com um edifício que é mais um padrão de glória para São Paulo”. Lamenta, entretanto, não ter conseguido instalar o projeto de Faculdade de Ciências Econômicas e Sociais. Almeida Prado, em explícito tom de embaraço com a indicação, assume não ter um programa a efetivar, mas apresentava-se disposto a corresponder aos sentimentos "do povo paulista, que espera que os novos dirigentes do Estado, agora empossados, consigam realizar a obra grandiosa do reerguimento político e financeiro de São Paulo” ${ }^{102}$.

Ainda em 1931, os democratas tentaram imprimir o projeto de universidade paulista aproveitando-se do fôlego político conquistado com a investidura de Laudo de Camargo. Apesar do relato de Fernando de Azevedo apontar para o fato de a primeira tentativa de criação da Universidade de São Paulo ter ocorrido em meados de 1932, sob o entusiasmo da publicação do Manifesto dos Pioneiros da Educação Nova, a averiguação dos nomes citados nos cargos públicos e do contexto político indicam que o "grupo do Estado" intentou, junto à gestão de Almeida Prado, concretizar a instalação da universidade tão logo foi indicado ao cargo. De acordo com Cardoso (1982, p. 106-107), Fernando de Azevedo apontou a formação de uma comissão que ficaria responsável por organizar o projeto do sistema universitário paulista, composta por Júlio de Mesquita Filho, Fernando de Azevedo, Alcântara Machado, Raul Briquet e Lúcio Rodrigues. A comissão teria iniciado o projeto com questões preliminares em

\footnotetext{
102 Diário de S. Paulo. Está completamente organizado o novo governo do Estado, 28 de julho de 1931 [Fundo
} Ernesto de Souza Campos, Curriculum Vitae, Vol.III]. 
reuniões na Escola Normal da Praça da República, sem ter chegado a termo, provavelmente pela instabilidade e falta de força política para sua implementação ${ }^{103}$.

A imprensa corrobora a hipótese de que a campanha pela universidade, apesar de arrefecida, continuou durante aquele ano. Na ocasião da visita a São Paulo do Diretor do Instituto de Educação Internacional de New York, Stephen Duggan, o secretário da Educação e Saúde Pública e o diretor geral do Ensino foram ao encontro do estrangeiro para saber sua opinião a propósito da oportunidade da instalação de uma universidade em São Paulo e dos moldes que deveriam ser adotados, logo que "a criação da Universidade Paulista preocupa seriamente o titular da pasta da Educação, que vem estudando a melhor forma de pôr em prática essa ideia” ${ }^{104}$.

Em janeiro de 1932, a classe médica paulista e convidados da Bahia e Rio de Janeiro, entre eles Carlos Chagas, do Instituto Oswaldo Cruz, participaram da Semana de Laboratório, evento promovido pela Sociedade de Medicina e Cirurgia de São Paulo e inaugurado com a presença solene do secretário da Educação e Saúde Pública, do prefeito da capital e representantes de associações médicas, entre os quais Souza Campos, na qualidade de presidente da Associação dos Antigos Alunos da Faculdade de Medicina e como um dos organizadores. O encontro científico foi noticiado pelo jornal Diário Nacional, órgão de divulgação do Partido Democrático, como sendo a prova de que São Paulo era "terra de cientistas” e tinha atingido sua “maioridade científica”. Em tom de crítica, o jornal utilizava o evento para vangloriar a vida acadêmica médica paulista e apontar a existência de rivalidades mesquinhas que eram contrárias ao "espírito superior de colaboração que soma esforços, o apreço mútuo que valoriza o trabalho e a boa camaradagem que estimula e auxilia”, chave que conduzia ao "grande futuro de São Paulo como centro de ciência",

\footnotetext{
${ }^{103}$ No relato de Azevedo, o projeto foi interrompido pelo estopim da revolução em 9 de julho de 1932.

104 O Estado de S. Paulo. A criação das universidades brasileiras, 13 de novembro de 1931 [Fundo Ernesto de Souza Campos, Curriculum Vitae, vol.III]. Interessante notar que nesse mesmo dia a gestão de Laudo de Camargo e Almeida Prado chegava ao fim, assumindo o posto de interventor o militar carioca Manuel Rabelo, com a pasta de Educação e Saúde Pública ficando em aberto até a nomeação do médico Francisco de Sales Gomes Júnior, em março de 1932, junto à posse de Pedro de Toledo, como tentativa fracassada de Vargas para apaziguar os ânimos paulistas pela sublevação do estado contra o governo provisório.

${ }^{105}$ Diário Nacional. A Semana de Laboratório veio demonstrar que S. Paulo é também terra de cientistas, 12 de janeiro de 1932; Diário Nacional. A Semana de Laboratório veio provar que S. Paulo já atingiu sua maioridade científica, 17 de janeiro de 1932; Folha da Manhã. Como ecoou no Rio a "Semana de Laboratório", 19 de janeiro de 1932. A comissão organizadora do evento foi composta por: Rocha Lima, Afrânio do Amaral, Ernesto de Souza Campos, Carvalho Lima e Altino Antunes [Fundo Ernesto de Souza Campos, Curriculum Vitae, Vol.III].
} 
O esforço paulista pelo bem da ciência, a “magnitude” espacial e científica da Faculdade de Medicina e o sucesso do evento científico ecoaram no Rio de Janeiro, por meio de entrevista cedida pelo médico microbiologista Arthur Moses ao jornal O Globo, e publicada na Folha da Manhã. Exaltando o espírito bandeirante paulista, a Faculdade de Medicina, com sua nova instalação, regime de tempo integral e curso pré-médico "representa um dos maiores auxiliares na formação de gerações médicas” e, junto com os institutos de pesquisa estão “perfeitamente irmanados, no melhor dos entendimentos, com o interesse da ciência pela ciência, [que] fazem de S. Paulo o Estado culto e vanguardeiro, grande pelo valor de seus filhos” ${ }^{\text {"106 }}$. Alguns dias após a realização do encontro acadêmico, foi assinado pelo chefe do governo provisório um decreto concedendo à Faculdade de Medicina de São Paulo as prerrogativas de equiparação ao modelo federal, reconhecendo oficialmente os diplomas por ela expedidos, ato que teria sido “aplaudido” pela imprensa carioca, que considerava a escola paulista como a verdadeira referência para equiparação da congênere federal ${ }^{107}$.

Apesar das conquistas no campo da pesquisa médica, que segundo o discurso da imprensa liberal alçava São Paulo ao patamar de estado preparado para a vida acadêmica universitária, o projeto paulista de universidade não saiu da condição de aspirações. Em fevereiro de 1932, em confronto à política federal o Partido Democrático e o Partido Republicano Paulista uniram-se em uma Frente Única contra o inimigo comum: o governo Vargas. O discurso político era alicerçado no retorno da constitucionalidade e, consequentemente, da autonomia do estado paulista frente ao governo federal. Como mola propulsora desse projeto unificado estava o imaginário de São Paulo como "locomotiva do país”, terra de bandeirantes, antepassados míticos que tornaram os paulistas descendentes homens destemidos e de bravura. Embora Vargas tenha acenado para o retorno da constitucionalidade naquele mesmo mês, promulgando o código eleitoral e agendando, em 14 de maio, a formação da Assembleia Nacional Constituinte para maio de 1933, a Frente Única iniciou um processo de revolta em 23 de maio, que acabou tornando-se armado em 9 de julho. A sublevação passou a ter progressiva adesão popular, graças à campanha propagandística elaborada pelos órgãos de comunicação. Estes apelavam para os símbolos da paulistanidade,

\footnotetext{
${ }^{106}$ Folha da Manhã. Como ecoou no Rio a "Semana de Laboratório" - Opinião do professor Arthur Moses sobre o cometimento paulista, 19 de janeiro de 1932 [Fundo Ernesto de Souza Campos, Curriculum Vitae, Vol.III]. 107 O Estado de S. Paulo. Um decreto sobre a Faculdade de Medicina de S. Paulo, 20 de janeiro de 1932 e Diário da Noite. A imprensa carioca aplaude o ato do governo equiparando a Faculdade de Medicina de São Paulo, 21 de janeiro de 1932 [Fundo Ernesto de Souza Campos, Curriculum Vitae, Vol.III].
} 
convencendo o cidadão à aderir a guerra “pelo bem de São Paulo”, buscando em suas entranhas o “orgulho paulista” (SANTOS; MOTA, 2010).

O acirramento político levaria a Faculdade de Medicina, junto à Faculdade de Direito e a Escola Politécnica a declararem apoio ao movimento insurgente contra o governo Vargas, em junho de 1932. Desde o ano anterior, as relações entre a classe médica paulista e o governo federal já estavam estremecidas, devido à centralização do projeto sanitário nacional, eliminando a autonomia do projeto sanitário paulista e a tentativa de tomada de espaços institucionais, como foi o caso da Instituto de Higiene, cogitado a transformar-se em quartel militar. Com o levante, a faculdade foi invadida pelas forças getulistas e muitos professores e alunos foram atuar nas frentes de batalha, nas corporações médicas de guerra, enquanto outros participaram organizando estratégias de arrecadação de recursos financeiros (MARINHO; MOTA, 2012, p.99).

A elite paulista se organizou para participar do levante. Em agosto, a Associação Comercial deu largada à Campanha do Ouro, que seria destinado a custear a fabricação de capacetes e armas, com o slogan "Doe ouro para o bem de São Paulo” (SANTOS; MOTA, 2010), causa aderida por Souza Campos, que doou seu anel de formatura em engenharia, além de ter atuado como clínico em hospital para soldados sediado na capital. Como presidente da Associação dos Antigos Alunos da Faculdade de Medicina, Ernesto de Souza Campos enviou ofício aos presidentes das sociedades médicas paulistas, sugerindo que a classe médica fizesse a oferta do anel simbólico recebido na formatura em medicina ${ }^{108}$. Além dessa iniciativa, a associação promoveu entre os pares a arrecadação de recursos para a aquisição da caneta de ouro usada para assinar a ata de lançamento da primeira pedra fundamental da faculdade, doada por Altino Antunes, assim como do anel de médico de Arnaldo Vieira de Carvalho, doado pela família em contribuição à causa paulista. Ambos objetos, pelo valor simbólico, seriam legados ao arquivo da faculdade ${ }^{109}$.

Os combates seguiram até outubro de 1932, quando o estado paulista assinou sua rendição. Para Santos e Mota (2010, p.80),

a revolta e a decepção geradas na população pela inesperada notícia da derrota só foi amainada pela propagação da noção de que, moralmente,

\footnotetext{
${ }^{108}$ ERNESTO DE SOUZA CAMPOS. Ofício da Associação dos Antigos Alunos da Faculdade de Medicina de São Paulo, 19 de agosto de 1932 [Fundo Ernesto de Souza Campos, Curriculum Vitae, Vol. III]

${ }^{109}$ Diário Nacional. Louvável iniciativa dos Antigos Alunos da Escola de Medicina, 20 de agosto de 1932; O Estado de S. Paulo. Anel de médico do Dr. Arnaldo Vieira de Carvalho, 23 de agosto de 1932. Souza Campos também doou objetos de arte na campanha "Cruzada Artística”, organizada por Olívia Penteado [Fundo Ernesto de Souza Campos, Curriculum Vitae, Vol. III].
} 
São Paulo saíra vitorioso das trincheiras, uma vez que a bandeira constitucionalista mostrava-se muito mais nobre comparada com as tendências demonstradas pelo governo de Vargas, abertamente acusado de ditador. Registrando esse clima nas semanas que se sucederam ao fim das hostilidades, Mário de Andrade anotou: "agora os paulistas trazem a cabeça em pé”. Assim, um dos mitos constitutivos dessa memória baseia-se na ideia de que São Paulo, mesmo derrotado nos campos de batalha, foi o vencedor moral.

No plano político, a derrota, apesar de ter representado uma grande humilhação aos paulistas, serviu para reforçar a aliança já existente entre PD e PRP em uma Chapa Única que, seguindo o calendário inalterado das eleições proposto por Vargas, concorreu às eleições com ampla vitória na composição da Assembleia Constituinte, em 1933. Em 1934, a Chapa Única dissolveu o PD e organizou um partido de base mais ampla, o Partido Constitucionalista, liderado por Armando de Salles Oliveira, interventor do estado de São Paulo desde agosto anterior (LOVE, 1982, p. 170-171), indicação claramente apoiada pela congregação da faculdade de medicina paulista ${ }^{110}$.

No ambiente da Faculdade de Medicina de São Paulo, assim como no plano político, enquanto o movimento de sublevação de 1932 significou para alguns o declínio de suas carreiras, "por outro lado, significou a subida ao poder de outros que, mesmo estando no front, se revelaram de imensa importância para o projeto getulista que foi se desenhando a partir de então” (MARINHO; MOTA, 2012, p.99). Entre eles, podemos citar Souza Campos, que durante meados da década de 1930 e início de 1940 compôs, junto a outros intelectuais, os quadros “técnicos” do governo Vargas, especificamente no Ministério da Educação e Saúde Pública.

Entre 1933 e 1934, Ernesto de Souza Campos continuou a dedicar-se às pesquisas e à docência na cadeira de Microbiologia. Por ocasião do vigésimo quinto aniversário da imigração japonesa em São Paulo, Souza Campos, entre outros cientistas, diplomatas e homens ligados ao comércio e indústria participou das comemorações do evento, noticiadas no Diário de S. Paulo. Sua colaboração foi a respeito da história da universidade nipônica e seus cientistas renomados, considerados como destaques para o desenvolvimento das ciências, especificamente no campo

\footnotetext{
${ }^{110}$ Em 25 de agosto de 1933, dias após a indicação por Getúlio Vargas de Armando de Salles Oliveira para a interventoria de São Paulo, a congregação da Faculdade de Medicina visitou oficialmente o novo comandante paulista, registrada em fotografia publicada pelo Diário da Noite. O mesmo apoio teria ocorrido por meio da comissão de professores que visitou pessoalmente Salles de Oliveira, com a missão de convidá-lo para participação no Congresso Médico Paulista, ocorrido em novembro de 1933 [Fundo Ernesto de Souza Campos, Curriculum Vitae, Vol. III].
} 
médico. Relembrou, entre outros médicos, os trabalhos do professor Noguchi, o qual conheceu durante o estágio nos Estados Unidos pela Fundação Rockefeller, pesquisador que manteve contato e intercâmbio de material científico ${ }^{111}$. Em novembro daquele ano, Souza Campos, como chefe da comitiva de alunos e professores da Faculdade de Medicina de São Paulo, partiu a navio para o Japão em "viagem de estudos e cordialidade”, com o apoio oficial da interventoria do estado e do consulado japonês, fazendo escala acadêmica nos Estados Unidos, onde visitou faculdades e organizações médicas na costa oeste. No Japão, o grupo permaneceu por três semanas em visitas e conferências, regressando ao Brasil via Índia e África do Sul, em 6 de abril do ano seguinte ${ }^{112}$. Dessa viagem resultou a publicação do livro Japão, de autoria de Souza Campos.

Enquanto Souza Campos visitava as universidade japonesas e celebrava os feitos da medicina paulista, em São Paulo decretava-se, em 25 de janeiro de 1934, a criação da Universidade de São Paulo pelas mãos de Salles de Oliveira e idealização do "grupo do Estado”, centralizada na figura de Júlio de Mesquita Filho. Com o controle do poder estadual devido ao compromisso político com o governo Vargas, a elite paulista instituiu a universidade como maior símbolo do projeto de nação liderada por São Paulo, em que se formaria a elite intelectual que levaria o país ao esplendor democrático. Animada pela elite intelectual e política durante a década de 1920, a Universidade de São Paulo nasceu com uma herança da revolução de 1932 e com um destino manifesto -- vencer pela ciência, como representação da vitória moral de São Paulo contra o governo federal (CARDOSO, 1982; SANTOS; MOTA, 2010, p.84).

Não menos “majestosas” foram as primeiras sessões do Conselho Universitário, ocorridas no salão nobre da congregação da Faculdade de Medicina, também casa da novel Faculdade de Filosofia, Ciências e Letras. O contexto de união e aparente harmonia entre os institutos superiores que levou à composição da universidade, no entanto, não duraria muito tempo.

\footnotetext{
${ }^{111}$ ERNESTO DE SOUZA CAMPOS. Universidades do Japão e cientistas médicos japoneses, [1933?] [Fundo Ernesto de Souza Campos, Curriculum Vitae, Vol. III].

112 Diário da Noite. Quatorze estudantes e cinco assistentes da Faculdade de Medicina de S. Paulo vão ao Japão, em viagem de estudos, 6 de novembro de 1933. Em entrevista oferecida por dois dos estudantes da caravana ao jornal $O$ Globo, a viagem teria sido iniciativa de alguns discentes da faculdade e paga com finanças pessoais, contando apenas com o apoio do consulado japonês. Entre os organizadores do empreendimento estava o sobrinho de Ernesto, Rubens Malta de Souza Campos, estudante de medicina [Fundo Ernesto de Souza Campos, Curriculum Vitae, Vol. III].
} 


\section{CONSOLIDAÇÃO DA OBRA: ESPÍRITO E CORPO DA UNIVERSIDADE}

Conjuntamente a fundação da Universidade de São Paulo, foi criada a Faculdade de Filosofia, Ciências e Letras, considerada no projeto de seus fundadores como suporte para a integração universitária, ou seja, necessária à formação do “espírito universitário” por promover estudos em comum para alunos de diferentes escolas. Essa integração também ocorreria com a convivência de professores e alunos em espaços e edifícios comuns ou em vilas universitárias, conforme consta na sessão do decreto de fundação da universidade (SÃO PAULO, 1934). Para que o "espírito universitário" fosse formado era necessário reunir em um mesmo espaço professores e alunos de diversas áreas do saber, com o objetivo de compartilhar a "experiência universitária”, a experiência da universalidade do conhecimento, o debate e troca constantes de ideias e o sentimento de pertencimento a uma mesma instituição. Essa ligação “espiritual”, que traria a marca da alma mater da universidade, deveria ser criada na FFCL, por meio da centralização das cátedras das ciências puras e desinteressadas provenientes dos outros institutos e pela união dos institutos universitários em um mesmo lugar, um refúgio acadêmico criado para consubstanciar a dinâmica universitária -- a cidade universitária. Dessa forma, o “espírito” (a FFCL) e o “corpo” (a cidade universitária) da Universidade de São Paulo seriam animados e materializados. Ernesto de Souza Campos teve papel fundamental na defesa e constituição desses dois elementos enquanto ocupou a cadeira de diretor da FFCL e da comissão de estudos para localização e organização do plano da cidade universitária, salvaguardando os princípios do projeto dos fundadores frente às resistências por eles enfrentados nos primeiros anos da universidade. No Rio de Janeiro, Souza Campos igualmente atuou ao lado dos idealizadores da Universidade do Brasil, defendendo no projeto da cidade universitária uma visão pedagógica da construção do espaço universitário em confronto com a visão dos arquitetos modernos.

\subsection{A FORMAÇÃO DO “ESPÍRITO UNIVERSITÁRIO”: A FFCL}

\subsubsection{Fundação da Faculdade de Filosofia, Ciências e Letras : contextos e contrapontos}

Cumprindo a diretriz do Estatuto das Universidades Brasileiras, a Universidade de São Paulo foi criada a partir da união dos institutos de ensino superior pré-existentes no estado paulista -- em especial as tradicionais Faculdade de Medicina, Escola Politécnica e Faculdade de 
Direito -- conjuntamente com a fundação da novel Faculdade de Filosofia, Ciências e Letras, uma variante da sugerida Faculdade de Educação, Ciências e Letras pelo decreto federal (CUNHA, 1980, itálicos nossos). A mudança sutil em relação aos cursos que comporiam a faculdade, no caso paulista, filosofia no lugar de educação, representava o posicionamento dos fundadores da universidade quanto às aspirações depositadas na instituição, evidenciando os mecanismos político-institucionais que levaram à viabilização de seu projeto.

Diferentemente do plano universitário do ministro Francisco Campos para a Universidade do Rio de Janeiro, a universidade paulista não tinha, em sua concepção, o objetivo principal de formar professores para o ensino secundário, mas sim cientistas, pesquisadores das ciências puras, futuros dirigentes políticos nacionais. No caso federal, a Faculdade de Educação garantiria, ao lado das pesquisas de “alta cultura” desenvolvidas nos departamentos de Ciências e Letras, a observância da função de caráter pragmático e de ação imediata sobre a cultura, por meio da formação de professores para o ensino normal e secundário, em uma tentativa de conciliar, mediante essa faculdade híbrida, os grupos em oposição representados na $\mathrm{ABE}$, órgão encampado pelo Ministério da Educação (MENDONÇA, 1994, p.39).

Nas terras bandeirantes, os esforços em formar os quadros docentes para o ensino secundário foram canalizados no projeto do Instituto de Educação ${ }^{113}$, em 1933, liderado por Fernando de Azevedo. À Universidade de São Paulo e à FFCL caberia um papel superior, o de formar as elites dirigentes paulistas que levariam a nação, por meio da ciência, ao trilhos da democracia e da civilização. A formação da “consciência nacional”, ponto chave para a reorganização da sociedade brasileira, passaria pela compreensão dos problemas pelos quais esta passava ao longo dos anos de 1920 e 1930.

Para que o destino da FFCL se cumprisse, o primeiro passo dado pelos fundadores foi buscar no exterior professores formados na "alta cultura", capazes de criar escolas de pensamento e desenvolver pesquisas de caráter puro e desinteressado na nova entidade e que não tivessem ligados à mentalidade "bacharelesca” e “autodidata” dos docentes nacionais, estes formados nas escolas profissionais e partidários do pragmatismo acadêmico (ANTUNHA, 1974). Para a composição do corpo docente da FFCL decretou-se que seria possível buscar

\footnotetext{
${ }^{113}$ O Instituto de Educação foi criado como escola de formação superior, em 1933, por Fernando de Azevedo, Diretor Geral da Instrução Pública do estado. Em 1934, foi incorporado à USP, sendo extinto em 1938, e tendo sua escola de professores se transformado na Seção de Pedagogia na Faculdade de Filosofia, Ciências e Letras. Sobre a história do Instituto de Educação e a Universidade de São Paulo, consultar Bontempi Jr. (2011a).
} 
professores estrangeiros, posto que a faculdade estava sendo instalada e que, na concepção dos fundadores, não existiam especialistas nacionais para tais disciplinas, dispensando dessa maneira os processos de concursos. Os criadores conseguiram implantar um sistema híbrido, no qual os contratados não ocupavam as cátedras como titulares, mas gozavam de regalias de catedráticos, tais como participar da congregação, eleger representantes e indicar assistentes (SÃO PAULO, 1934). A contratação, que era para ser regime de exceção, foi regra, e assim os "professores estrangeiros constituíram a maior parte do corpo docente da Faculdade de Filosofia, Ciências e Letras durante os primeiros anos da USP” (PETITJEAN, 1996a, p.259).

Em março de 1934, Theodoro Ramos, nomeado diretor da FFCL, foi à Europa com a missão de estudar o funcionamento das universidades e contratar docentes, em representação a Mesquita Filho. De forma geral, a distribuição prevista pelos fundadores antes da partida foi contemplada: missão francesa no âmbito das letras e ciências sociais, missões italiana e alemã para as exatas e naturais. Ao quadro de professores estrangeiros, juntaram-se três brasileiros nas cadeiras de etnologia, língua tupi-guarani, física e biologia, esta última preenchida por André Dreyfus, que migrou da Faculdade de Medicina. Os cursos da FFCL somente começaram a funcionar no mês de julho (PETITJEAN, 1996a, p. 262-269).

Para Petitjean (1996a, p. 260-261; 1996b, p.91 - 93), a influência cultural exercida pela França na composição do quadro docente era consequência de uma política científica e cultural de longa data, nascida com a missão artística de Debret no século XIX e de uma cooperação universitária intensa desde o início do século $\mathrm{XX}$ sob as diretrizes do Groupement des Universités et Grandes Écoles de France pour les Relations avec l'Amérique Latine. O Groupement foi fundado em 1907, no Collége de France, em Paris, pelos físico Henry Le Chatelier e matemático Paul Appel, como resultado de uma iniciativa da comunidade de cientistas de promover o intercâmbio científico e a difusão da cultura francesa, por ser considerado elemento importante da influência francesa no mundo, em oposição às rivais imperiais Alemanha e Itália e à nação norte-americana. O médico Georges Dumas foi o primeiro enviado especial do grupo à América Latina em 1908, onde retornou inúmeras vezes durante as duas décadas seguintes para assinar acordos de cooperação interuniversitários. Essa política científica e cultural formou laços pessoais entre Dumas e professores franceses, como Robert Garric e Paul Fauconnet, e os brasileiros Julio de Mesquita Filho, o "grupo do Estado", médicos e engenheiros docentes das escolas profissionais superiores de São Paulo. 
Na capital paulista, Georges Dumas criou, em 1925, o Liceu Franco Brasileiro para coordenar a vinda de conferencistas para a sociedade "esclarecida”, e o Instituto Técnico Franco-Paulista, com o objetivo de difundir a cultura técnica francesa. Esta iniciativa contou com o apoio de José Lobo, secretário do interior; Geraldo de Paula Souza, diretor do Instituto de Higiene; Ramos de Azevedo, diretor da Escola Politécnica e Pedro Dias da Silva, diretor da Faculdade de Medicina. Apesar do empenho em estimular cursos de maior duração, o instituto durou apenas um ano, e a ação francesa permaneceu no campo das conferências de docentes de passagem pela América Latina até a formação da missão francesa para a universidade (PETITJEAN, 1996b).

Na década de 1930, a difusão científica francesa do Groupement havia perdido progressivamente espaço para a dimensão cultural e diplomática, devido ao acirramento do contexto político internacional entre as correntes fascistas, liberais e comunistas e a anexação deste órgão ao Service des Oeuvres do Ministério das Relações Estrangeiras da França, comandado por Jean Marx. Como braço diplomático do Estado, o Groupement passou a agir no combate cultural e político em defesa de valores da "latinidade”, como a cultura geral, a língua francesa e o positivismo, buscando eco na identificação das elites latino-americanas com sua moral. Gradualmente, os intelectuais ligados ao Groupement passaram a atuar como políticos, o que gerou, em consequência, a diminuição do prestígio de Georges Dumas nos círculos universitários franceses e seu isolamento em algumas áreas do saber, como as ciências exatas e naturais ${ }^{114}$. Assim, a política científica e cultural francesas no Brasil teria como objetivo "tecer redes de aliados políticos a partir de uma influência cultural e política” (PETITJEAN, 1996b, p.91).

Ora, as características que definiram a política de difusão científica e cultural francesas iam ao encontro dos posicionamentos do projeto político pedagógico defendidos pelo "grupo do Estado" em relação ao papel da universidade. Os valores da "latinidade”, especialmente a ideia de cultura geral e liberalismo como princípios necessários para a elite paulista tomar a

\footnotetext{
114 Tal situação pôde ser comprovada com a dificuldade de Dumas em contratar, para a missão francesa na USP, professores renomados, os mestres da "alta cultura" como era esperado pelos brasileiros. Segundo Petitjean (1996a), das missões estrangeiras que vieram para preencher as cadeiras da FFCL, a francesa era a que tinha a menor faixa etária e menor titulação, sendo uma exceção docentes que estavam vinculados às universidades. Além disso, Dumas não conseguiu acertar professores franceses para as cadeiras das ciências exatas e naturais. Ainda, do grupo que havia formado a primeira missão francesa (seis professores), quatro retornaram à Europa no ano seguinte, anunciando os reveses que Dumas passaria para contratar docentes que aceitassem se estabelecer no Brasil por pelo menos três anos, como era esperado pelos fundadores da universidade. Por conta dessa situação, ocorreu, até 1940, a vinda de três missões francesas, que por fim se estabilizou por conta do início da Segunda Guerra Mundial e da adaptação dos professores à universidade brasileira.
} 
“consciência nacional” e assumir sua função política de liderar o país para a democracia seriam obtidos justamente sob a égide cultural francesa. Portanto, as disciplinas consideradas de “formação do espírito” foram delegadas à missão francesa, por seu teor de aproximação cultural, assim político e pedagógico, segundo os critérios dos fundadores da universidade.

A política de difusão cultural francesa inscrevia-se internacionalmente no quadro de disputas políticas e econômicas entre as grandes potências imperiais e o despontar hegemônico dos Estados Unidos. A América Latina tornou-se nesse contexto um “laboratório” do campo de forças entre essas nações, expressa também em rivalidades no âmbito científico, levando a uma situação em que “os intelectuais latino-americanos polemiza[va]m regularmente a respeito dos fundamentos da união da América do Sul: união latina, com abertura para a Europa, ou união pan-americana, o que implica[va] admitir a hegemonia crescente dos EUA” (PETITJEAN, 1996b, p.100).

Se os franceses obtiveram o domínio das áreas das ciências sociais e literárias na formação da FFCL, sua política era inadequada e insuficiente para corresponder às demandas brasileiras nas áreas das ciências duras, algo claro para o matemático Theodoro Ramos e igualmente para os articuladores do Groupement que, nas palavras Robert Garric, receava o perigo da americanização da vida intelectual em São Paulo pela dificuldade de corresponderem à demanda paulista (PETITJEAN, 1996b, p.108). A composição multinacional da FFCL, dividida basicamente entre mestre franceses, italianos e alemães, expressa na realidade uma disputa de lugares dessas nacionalidades na comunidade científica internacional. Os Estados Unidos, já ancorados na estrutura universitária paulista por meio da instalação do modelo Rockefeller na Faculdade de Medicina, conquistariam, a partir do final da década de 1930, espaços na FFCL nas pesquisas das áreas das ciências biológicas e exatas (MARINHO, 2001).

A divisão feita na composição dos quadros da FFCL, em 1934, já anunciava posteriores disputas internas, eclodidas ainda mesmo na década de 1930 e intensificada nas seguintes. Acompanhava a lógica do declínio do "prestígio cultural” francês e a caducidade da concepção de cultura geral frente aos avanços das ciências especializadas, que progressivamente dominavam o cenário científico internacional (PETITJEAN, 1996b).

A USP e a FFCL, dessa maneira, já nasceram como um híbrido de concepções e políticas universitárias, seguindo uma lógica de apropriação de aspectos de diferentes modelos universitários, de acordo com as necessidades do local e do momento de cada instituição, conforme pontua Charle (2013), ao defender uma análise transnacional da historiografia do 
ensino superior, especialmente a partir do século XIX. Se a França fez escola com sua missão, estruturalmente pode-se afirmar que a USP é herdeira de uma concepção de universidade alemã, especificamente humboldtiana, que estava ancorada no binômio ensino e pesquisa, já apropriada pelos franceses durante a reforma de suas universidades no final do século XIX, da qual o núcleo de cientistas do Groupement havia participado ${ }^{115}$. Historicamente, a Faculdade de Filosofia como núcleo da universidade por seu papel de pesquisa pura e desinteressada foi um fenômeno da universidade alemã do início do século XIX. A presença da tradição alemã na FFCL, apesar de ser reduzida a alguns professores, também fez-se presente na concepção de universidade como local de pesquisa, representada pela Faculdade de Filosofia como centro. A Universidade de Berlim, criada em 1809, estava livre do peso da tradição e tinha como missão fundamentar uma nova nação cultural e política. Baseada no princípio da autonomia externa (em relação ao Estado e à sociedade) e interna (liberdade acadêmica), este modelo alçava à filosofia papel preponderante de crítica e unificação do conhecimento (princípio da universalidade da ciência) e caracterizava-se por ser um modelo de universidade idealista (CATROGA, 2011, p.34-35).

Seguindo esses preceitos, que generalizaram-se nas universidades europeias e norte-americanas no século XIX e início do XX (CHARLE, 2013), e estavam afinados com os defendidos pelos fundadores da USP em franca oposição aos partidários da formação técnica, Souza Campos, dado seu credenciamento como especialista em ensino superior e "apostolado" pela universidade como local de pesquisa científica nucleado na FFCL, foi convidado a ocupar cargos e posições estratégicas dentro da Universidade de São Paulo em um momento delicado de sua história, quando ainda em consolidação enfrentou forte resistência por disputas internas de grupos de professores que representavam diferentes concepções de universidade.

\footnotetext{
115 O modelo universitário francês teve uma formação distinta do alemão, pois suas principais instituições de ensino superior não eram as universidades, mas as grandes Écoles, gestadas no século XVIII. Mesmo tendo o impacto da reforma universitária alemã, as écoles continuaram a ser os principais centros de altos estudos, pois eram os locais de formação da mais alta cúpula estatal. A universidade reformada do período napoleônico não se propôs a romper com o sistema das grandes Écoles, centros de formação especializada e pragmática. Portanto, o ensino superior francês caracterizava-se pela dualidade, mesmo com as tentativas de reformas empreendidas no final do século XIX, que lutavam contra a excessiva profissionalização e a dispersão e fragmentação das faculdades pelo país, mas tinham em seu cerne a ideia da aprendizagem a serviço de motivações morais e cívicas. Nesse período, tentou-se implantar a ideia da universidade como local de produção científica, com base principalmente nas ciências sociais, área dominada pela doutrina positivista, que teria isolado a filosofia (CATROGA, 2011, p.16-28).
} 


\subsubsection{Contestações ao projeto da FFCL durante a diretoria de Ernesto de Souza Campos}

Em junho de 1937, Ernesto de Souza Campos foi nomeado diretor da Faculdade de Filosofia, Ciências e Letras ${ }^{116}$, permanecendo no cargo por um ano, a convite do secretário da Educação Cantídio de Moura Campos, em substituição a Antônio de Almeida Prado, que dirigia a faculdade desde 1934 e atuava como vice-reitor. Se naquele momento o contexto político apontava para o acirramento das disputas por conta da corrida para as eleições presidenciais de 1938 contra as estratégias de permanência de Vargas no poder, vitoriosas no golpe militar deflagrado em novembro de 1937, não menos conturbado estava o ambiente da FFCL. Em relatório endereçado ao reitor como prestação de contas por sua gestão, Souza Campos (1938b, p.7) narra que sua indicação ao cargo de diretor da FFCL ocorreu em um “período angustioso por que passou esta Faculdade”, tendo como missão “dirigir e defender a instituição cujos destinos me foram confiados”. A sobrevivência do projeto da alma mater, de fato, estava sob ameaça.

Conforme pontuou Petitjean (1996a, p.321), ao analisar os desafios passados pelas missões francesas na universidade,

a situação conflituosa é tanto mais permanente quanto se nutre do conflito não resolvido que tinha marcado o nascimento da USP: o conflito entre as escolas profissionais (a Politécnica, a Faculdade de Medicina, a Faculdade de Direito) e a FFCL. A resistência, para não dizer a hostilidade aberta, nunca tinha cessado. Todas as medidas tomadas só faziam atenuar essa resistência, sem jamais conseguir fazê-la desaparecer.

Bontempi Jr. (2011b, 2016) têm apontado algumas razões dessa resistência ao projeto da FFCL por parte das congregações das escolas profissionais, especialmente no que tange ao campo simbólico. A Faculdade de Direito, a Escola Politécnica e a Faculdade de Medicina constituíram suas identidades a partir de tradições distintas, condizentes com as expectativas de seus idealizadores sobre seu papel na sociedade. O engenheiro, o bacharel e o médico traziam consigo uma mística sobre sua formação, que passou a ser questionada e minimizada pela nova tradição universitária implantada pelo decreto de fundação da USP, que delegava ao filósofo posição de destaque, considerado por Júlio de Mesquita Filho como a "elite da elite” da universidade. Conforme o autor, se em 1934 as escolas profissionais uniram-se em uma frente

\footnotetext{
${ }^{116} \mathrm{Na}$ estrutura de poder da universidade, a cátedra era o cargo básico para que o docente ascendesse aos postos da gestão. Somente os catedráticos brasileiros natos poderiam ser nomeados, pelo governo do estado, para os cargos de diretor e reitor, o que acarretava a investidura de catedráticos de outras unidades para a diretoria da FFCL, majoritariamente composta por professores estrangeiros contratados.
} 
ampla pela paulistanidade, levando a cabo a fundação da USP como resposta à derrota da Revolução de 1932, não demorou para que as disputas de poder, de autonomia, concepção de ciência e tradições levassem o projeto da universidade a situações de instabilidade e conflito interno.

\begin{abstract}
O que havia de comum nessas manifestações, e que era traduzido nas sessões rituais [formaturas da FFCL] como 'incompreensões' das altas aspirações dos bandeirantes da cultura, portanto, como ignorância e mesquinhez diante dos benefícios civilizatórios das iniciativas em prol do controle da produção de ciência e da formação cultural pela FFCL, era a demonstração de que os ideais do grupo de Mesquita Filho não eram consensuais em todos os círculos da elite ilustrada paulista, cujas frações, em defesa de suas respectivas instituições, reagiram à imposição unilateral de uma 'integração universitária' pela qual fossem submetidas à Faculdade de Filosofia. Essa reação, diferentemente da interpretação pretendida na FFCL, não era motivada por conservadorismo e apego ao passado, mas pela pretensão dos grupos rivais em tornar viáveis os seus próprios projetos de modernidade, dos quais as instituições de ensino superior eram portadoras (BONTEMPI Jr., 2008, p. 178).
\end{abstract}

Dois episódios ocorridos em 1937 representam as contendas que os defensores da FFCL passaram para a consolidação do “espírito universitário” sobre os outros “espíritos” das escolas profissionais, ocasiões em que Souza Campos foi elemento crucial para a manutenção do projeto da Faculdade de Filosofia e da USP.

No ano de sua instalação, a FFCL não contava com espaço próprio para suas cadeiras. Em decorrência, os cursos foram implantados em espaços da Faculdade de Medicina (Zoologia, Botânica e Biologia Geral, Química, Mineralogia, Filosofia, Letras, Geografia, História, Ciências Sociais e Políticas e o setor administrativo) e da Escola Politécnica (Física e Matemática). Com o decorrer dos anos letivos, houve a necessidade de ampliação dos laboratórios de química na sede da Medicina, o que levou a uma celeuma entre os médicos e os filósofos, ocasionando a saída definitiva da FFCL deste prédio (BONTEMPI Jr., 2011b). Mesmo não dando maiores detalhes sobre o incidente, Souza Campos denota que o problema do espaço para o bom andamento da Faculdade deveria ser primordialmente resolvido, pois assim "ficaria a Faculdade de Medicina com os seus departamentos integrados na sua vida anterior e teriam estas seções da Faculdade de Filosofia mais liberdade de ação no desenvolvimento do seu trabalho”(CAMPOS, 1938b, p.15).

Assim que tomou posse, procurou uma sede própria para a unidade, que teria os cursos do segundo semestre iniciados dentro de dezessete dias. Com o curto período de tempo, optou 
por remover algumas seções (as que eram ligadas a laboratórios continuaram provisoriamente na Medicina até a possibilidade de transferência adequada, assim como as seções que estavam na Escola Politécnica) e a administração para um prédio municipal, como medida emergencial. Essa instalação provisória foi substituída no ano seguinte pelo palacete da Alameda Glete, escolhido por Souza Campos e adquirido pelo estado, como o mais satisfatório pela localização, dimensões e valor comercial. A primeira sede própria da faculdade comportou os cursos já transferidos e, quanto ao pavilhão da Química, inacabado na Faculdade de Medicina, Souza Campos tratou de utilizar a verba restante que tinha sido destinada à obra para a construção no novo terreno, em andamento no ano de 1938 (CAMPOS, 1938b).

Se a questão com a Faculdade de Medicina foi resolvida em curto prazo, o mesmo não ocorreria com os atritos entre a FFCL e a Escola Politécnica, que tocaram no âmago do projeto político pedagógico da Faculdade de Filosofia e da Universidade de São Paulo: a centralização das cátedras de ciências fundamentais, até então existentes nas escolas profissionais, na unidade nuclear da universidade como condição para a criação do “espírito universitário”.

De acordo com memorial apresentado pela Congregação da Escola Politécnica ao Conselho Nacional de Educação ${ }^{117}$, a origem do conflito entre a escola de engenharia e a FFCL teria se configurado nas sessões do Conselho Universitário em meados de 1936, onde deliberou-se sobre o provimento de cadeira comum a Faculdade de Ciências e Politécnica, dada a um professor estrangeiro. A Congregação da Politécnica impugnou a regência da cadeira pelo referido docente, ancorado na prerrogativa dela ter competência superior para julgar matéria didática, e a partir dela, afirmar que a experiência com os professores estrangeiros não era satisfatória pois sua formação como cientistas não permitia que seus trabalhos fossem aplicados a profissão do engenheiro, conforme era previsto no regulamento da Escola (UM CONFLITO..., 1937).

Em abril de 1937, foi dado ciência no Conselho Universitário a respeito de ofício da Faculdade de Direito sobre projeto de centralização dos cursos universitários ${ }^{118}$ na FFCL (RANIERI, 2005, p.38). No relato, a Congregação da Politécnica narra que, um mês antes,

\footnotetext{
${ }^{117}$ Neste memorial constam os diversos documentos referentes ao caso, tanto os pareceres da Congregação da Politécnica quanto do Conselho Universitário e a defesa de voto de Ernesto de Souza Campos. Por essa razão, usaremos esse registro como base documental para análise dos posicionamentos da Congregação e de Souza Campos.

${ }^{118}$ Na data, o diretor da Faculdade de Direito era Francisco Morato, fundador do Partido Democrático e líder da Frente Única Paulista contra o governo provisório. Morato havia retornado do exílio pela derrota da Revolução de 1932 para trabalhar no governo Salles Oliveira e, em 1935, assumiu a cadeira de diretor da Faculdade no lugar de Alcântara Machado d'Oliveira (FUNDAÇÃO GETULIO VARGAS, 2017a).
} 
como forma "preventiva”, havia enviado ao Conselho Nacional de Educação um memorial ${ }^{119}$ contendo seu parecer em oposição ao projeto de unificação das cadeiras, com disposições que acabaram sendo incorporadas no Plano Nacional de Educação ${ }^{120}$, elaborado sob a presidência de Reynaldo Porchat, primeiro reitor da USP.

Desde 1935, a centralização dos cursos universitários propedêuticos nas Faculdades de Filosofia, Ciências e Letras, ao lado da definição do tipo de universidade que seria adotada para o país estava em pauta, pois foram os pontos deliberados pela comissão de professores convocada pelo Ministro da Educação Capanema “especialmente designada para o estudo de uma 'organização universitária modelar' na capital da República”, que seria utilizado como subsídio para o Plano Nacional de Educação. Para Souza Campos, único membro dessa comissão advindo da Universidade de São Paulo, composta por docentes da Universidade do Rio de Janeiro, da Escola Politécnica do Rio de Janeiro, entre outros institutos científicos (FÁVERO, 1980, p.96), a opção pela centralização das cadeiras teria resultado da análise de “muitos professores universitários que se tem dedicado especialmente aos problemas educacionais” e estão em “postos de direção dos nossos mais altos centros de estudos” (UM CONFLITO..., 1937, p. 147-148).

De acordo com Souza Campos, o tipo de universidade escolhida para o caso brasileiro foi o tipo contemporâneo, constituído por um "núcleo fundamental -- a Faculdade de Filosofia, Ciências e Letras em torno da qual se agrupam Faculdades, Escolas ou Institutos de ensino superior”. Não deveriam adotar o tipo profissional puro ou utilitário, como haviam preconizado alguns debatedores na ocasião da propaganda pela universidade, nos anos 1929 e 1930, no Rotary Club de São Paulo, pois nas universidades a FFCL seria um elemento indispensável. No caso da Universidade do Brasil, antiga Universidade do Rio de Janeiro, a comissão organizadora dos trabalhos propôs a enumeração das faculdades que poderiam fazer parte da universidade, entre elas a Escola Politécnica e a Faculdade de Química, que juntas formavam a

\footnotetext{
119 Este documento foi assinado pelos professores: Henrique Jorge Guedes, Victor da Silva Freire, A. Martins Barbosa, Mário Whately, Bruno Simões Magro, Ed. Ribeiro Costa, Clodomiro Pereira da Silva, Luiz de Anhaia Mello, Lysandro P. Silva, João F. de Ulhôa Cintra, A. C. Cardoso, Lúcio M. Rodrigues, Eugênio Lindenberg e Gaspar Ricardo Júnior (UM CONFLITO..., 1937, p.100).

${ }^{120}$ O Conselho Nacional de Educação foi empossado em 11 fevereiro de 1937 e instalado em 16 do mesmo mês. Tinha como uma das principais atribuições elaborar o Plano Nacional de Educação, para ser aprovado pelo Poder Legislativo. Devido à importância desse Plano, viu-se a necessidade da elaboração de um regimento interno próprio para reger os trabalhos da elaboração do PNE. Foram designadas vinte comissões especiais, encarregadas de tratar de cada assunto, de acordo com o nível e área do saber, ficando a comissão da redação final a cargo de Lourenço Filho, Amoroso Lima, Reynaldo Porchat, Pe. Leonel Franca e Raul Leitão da Cunha. Na sessão de 17 de maio de 1937, última da elaboração do PNE, foi assinado o anteprojeto com a leitura da Redação Final, encaminhado ao Ministro da Educação e Saúde Pública (CURY, 2013).
} 
Universidade Técnica, de acordo com o tipo das Technische Hochschule alemãs. Incorporada à organização universitária com a reestruturação da Universidade do Brasil, em julho de 1937, a Universidade Técnica foi extinta. A mesma diretiva deveria ser seguida para a Universidade de São Paulo e nas universidades de Minas Gerais e Rio Grande do Sul (UM CONFLITO..., 1937, p.149-151).

Defensores da centralização das cadeiras, Souza Campos e Azevedo do Amaral ${ }^{121}$, um dos ideólogos das diretrizes educacionais do Estado Novo ao lado de Capanema (FÁ VERO, 1980, p.91), passaram a publicar artigos sobre o tema na imprensa, explicando os argumentos do projeto e suas vantagens para a constituição da universidade brasileira. Para esses professores, a organização do ensino superior em formato universitário seria o ideal, pois promoveria o intercâmbio direto e bem dirigido entre as instituições que compõem a universidade. O primeiro ponto necessário para o ajuste seria a alteração dos regulamentos de cada unidade, para se adaptar às novas condições. O sistema universitário traria vantagens, pois conjugaria cadeiras e estruturas que eram similares ou idênticas em diferentes escolas, como o caso das matemáticas, físicas, químicas, etc, conceituado por eles como cursos de formação elevada, diferentes da natureza dos cursos de disciplinas propedêuticas de medicina e odontologia, que não eram tão exigentes. Outro ponto essencial para a centralização seria o Colégio Universitário articulado à Faculdade de Filosofia, Ciências e Letras, auxiliando na formação do “espírito universitário” dos estudantes ${ }^{122}$.

Engrenando porém a Faculdade de Filosofia, Ciências e Letras com o Colégio Universitário e devendo todos os estudantes universitários frequentar este curso intermediário entre o curso secundário e o curso superior é evidente que através deste aparelhamento haverá não só uma influência geral na Faculdade de Filosofia sobre todos os alunos universitários como também, deste critério resultará uma boa homogeneização dos conhecimentos adquiridos em curso ginasial os mais diversos distribuídos em todo o país. Esta será, sem dúvida uma das maiores vantagens da centralização universitária ${ }^{123}$.

\footnotetext{
${ }^{121}$ Inácio Manuel Azevedo do Amaral formou-se na Escola Naval do Rio de Janeiro, onde também foi docente. Trabalhou como professor de matemática no Colégio Dom Pedro II e diretor na Escola Normal do Distrito Federal. Em 1926, obteve, por concurso, a cátedra de geometria analítica e cálculo infinitesimal na Escola Politécnica, cuja congregação representou, de 1930 a 1934, no Conselho Universitário do Distrito Federal. Chefe do Departamento de Ensino do Armamento da Escola Naval a partir de 1931, integrou de 1932 a 1938 o conselho técnico-administrativo da Escola Politécnica do Rio de Janeiro. Diretor do Escritório do Plano da Universidade do Brasil a partir de 1935, integrou, até 1937, o Conselho Nacional de Educação (FUNDAÇÃO GETULIO VARGAS, 2017b).

${ }^{122}$ ERNESTO DE SOUZA CAMPOS; INÁCIO AZEVEDO DO AMARAL. O Estado de S. Paulo. O problema educativo, 9 de abril de 1937 [Fundo Ernesto de Souza Campos, Curriculum Vitae, Vol.VI]

${ }^{123}$ Ibidem.
} 
Assim como Souza Campos, Inácio Azevedo do Amaral, como membro do CNE, pronunciou-se partidário da centralização das cadeiras, tese que acabou aceita com unanimidade pela comissão dos professores da UB e adotada no Plano Nacional de Educação, na seguinte redação do Art. 459:

1a.- O ensino das ciências puras fundamentais, comuns a vários cursos universitários, deverá ser centralizado na Faculdade de Ciências e nos Institutos especializados que venham a ser criados para o ensino das mesmas ciências, realizando-se assim uma unidade de instalações e de aparelhagem didática em tudo que diz respeito a laboratórios, gabinetes, museus e bibliotecas especializadas.

2a.- Os cursos de ciências puras fundamentais, para a preparação às diferentes carreiras profissionais, serão realizadas de acordo com programas especiais, seguindo a orientação que for estabelecida em cada curso pela congregação da respectiva escola técnica, e serão dados pelos respectivos professores das mesmas escolas (UM CONFLITO..., 1937, p. 10-11, itálicos do autor).

Caminhando no mesmo sentido do governo federal, na reunião do Conselho Universitário de 20 de maio de 1937, a Secretaria da Educação ${ }^{124}$ do governo paulista encaminhou anteprojeto visando centralizar na Faculdade de Filosofia, Ciências e Letras as cadeiras de ciências fundamentais dos institutos da universidade, no termo do decreto estadual 24.279, de 22 de maio de 1934, que aprovou a regulamentação do artigo terceiro do Estatuto das Universidades Brasileiras ${ }^{125}$, em segunda tentativa de efetivar o projeto de formação do “espírito universitário” por meio da centralização das cátedras na FFCL. Na ocasião, as congregações dos institutos foram ouvidas e a Escola Politécnica apresentou-se contrária novamente, apontando que qualquer deliberação deveria atender ao dispositivo do artigo 44 do decreto federal $^{126}$, ficando o impasse jurídico a cargo da avaliação da Faculdade de Direito. Em 30 de agosto, sessão em que Ernesto de Souza Campos participou como diretor da FFCL, após ampla discussão, o parecer da Comissão de Ensino e Regimento aprovou a proposta de união

\footnotetext{
${ }^{124}$ Itálicos nossos. O governador do Estado do período era José Joaquim Cardoso Melo Neto, catedrático da Faculdade de Direito e membro do Partido Constitucionalista, e o secretário da educação, Cantídio de Moura Campos, professor da Faculdade de Medicina, no posto desde a gestão de Armando de Salles Oliveira (LOVE, 1982).

${ }^{125}$ Decreto-lei 19.851/31, Art. $3^{\circ}$ : O regime universitário no Brasil obedecerá aos preceitos gerais instituídos no presente decreto, podendo, entretanto, admitir variantes regionais no que respeita à administração e aos modelos didáticos (BRASIL, 1931).

126 Decreto-lei 19.851/31, Art. 44: O conselho universitário, de acordo com o parecer das congregações respectivas, poderá centralizar em um só instituto universitário o ensino de disciplinas fundamentais, cujo conhecimento habilitem a continuação dos estudos superiores de natureza técnica ou cultural. Parágrafo único. No caso previsto neste artigo, serão organizados programas de ensino de acordo com o critério do melhor aproveitamento da disciplina fundamental nos estudos superiores consecutivos (BRASIL, 1931).
} 
das disciplinas fundamentais em um único instituto, encaminhada pelo Governo do Estado ao Conselho Universitário (RANIERI, 2005, p. 38).

Para a Congregação da Politécnica, o parecer emitido ao CNE e ao Conselho Universitário demonstrava “à saciedade que a reunião das cadeiras constituía, não somente clamorosa falta de compreensão do regime universitário, como regresso franco em matéria de ensino técnico" (UM CONFLITO..., 1937, p.7, itálicos nossos). No entanto, a discussão ocorrida no seio do Conselho Universitário contou com um fato "único” que teria marcado sua decisão: "um dos membros do Conselho publicou, pela imprensa, desenvolvidamente, a sua declaração de voto. Personalidade de responsabilidade no caso, foi essa declaração que conduziu, orientou, liderou o Conselho Universitário da Universidade de São Paulo” a aprovação do projeto, como uma contraprova ao parecer da Congregação da Politécnica (UM CONFLITO...,1937, p.7). O autor deste pronunciamento no jornal O Estado de S. Paulo foi Ernesto de Souza Campos, diretor da Faculdade de Filosofia, Ciências e Letras.

Em artigos publicados no decorrer do mês de setembro, Souza Campos legou à opinião pública os argumentos e motivos de sua defesa pela centralização das cátedras na FFCL. Ancorado na experiência de diversos centros universitários em alguns países, retomou a arguição a favor da centralização das cátedras e do tipo ideal para a universidade brasileira, nucleada na Faculdade de Filosofia, Ciências e Letras. Desta maneira, para Souza Campos estava

fora de dúvida que este é o tipo universitário [tipo contemporâneo] recomendado pelos educadores brasileiros e que está mais de acordo com as nossas possibilidades e as nossas conveniências. Seria de todo absurdo constituir em São Paulo um Technische Hochschule segundo o tipo de Zurique que é, na realidade, uma instituição universitária [...]. Teríamos assim de organizar, à custa do Estado, duas universidades, quando ainda não está em plena maturação a Universidade de São Paulo, fundada há apenas 3 anos. Não é pois adaptável ao nosso meio o tipo tradicional puro [Faculdades de Filosofia, Teologia, Direito e Medicina], do qual são excluídos os cursos de engenharia, admitindo-se no conjunto universitário apenas as quatros faculdades clássicas. O conceito brasileiro está de acordo com nossa tradição (UM CONFLITO..., p.151-152, itálicos nossos).

Souza Campos colocava-se ao lado do educadores brasileiros, que vinham, desde a década de 1920, lutando pela constituição da universidade como local de ciência, em detrimento da técnica e do bacharelismo. Por essa razão, defendia um conceito de universidade, que chamou de conceito brasileiro, e que correspondia às condições e necessidades da formação do 
ensino superior nacional. Cabe ressaltar que o tipo de universidade defendida por Souza Campos, nomeada de tipo misto ou contemporânea ganhou, no prelúdio do Estado Novo, contornos nacionais. Essa transição semântica explica, na realidade, sua filiação intelectual ao projeto universitário do governo federal, que ia ao encontro do projeto universitário da USP. Conforme Lahuerta (1997, p. 95), o sentimento de missão dos intelectuais da década de 1920, genericamente modernista, aprofundou-se, nos anos 1930, com contornos nacionais, buscando o “brasileiro” e tendo no Estado o “desaguadouro de todas as inquietações”. A politização das questões culturais e o tema do moderno passaram a ficar submetidos ao projeto de construção nacional, pela força catalizadora do Estado em efetivar diferentes visões intelectuais, dentro de um consenso da intelectualidade sobre a necessidade de unificar o país (LAHUERTA, 1997, p.100).

O nó da questão para a Congregação da Escola Politécnica da Universidade de São Paulo estava justamente na falta da devida compreensão do referido artigo por parte de Ernesto de Souza Campos e do Conselho Universitário, classificando a interpretação deles como “cegueira, pois da pior espécie: a cegueira 'de quem não quer ver”, ${ }^{127}$. Argumentavam que no PNE estava explícita a recomendação para centralizar as instalações e aparelhagem didática, porém, era indicada a descentralização do ensino, com professores separados, de cada congregação, submetido a programas, orientações e métodos por elas traçados (UM CONFLITO..., 1937, p. 17). Estava, portanto, exposto o golpe desferido à Congregação da Politécnica: a impossibilidade de escolher os professores, estes engenheiros, em detrimento de cientistas como matemáticos e físicos, que foram recrutados no exterior como condição dos fundadores para a criação do “espírito universitário” e científico da universidade. Apesar de parecer ser este conflito motivado pela vaidade, ele tinha raízes mais profundas, ligadas a um debate entre a concepção de ciência pura e aplicada, além de um conceito diverso sobre a organização universitária.

Conforme Bontempi Jr. (2016, p.106-107), a defesa da Congregação era decorrente de um projeto de Universidade Técnica inspirado nas Technische Hochschule, que teria como

\footnotetext{
127 Esta cegueira, segundo a Congregação da Politécnica, igualmente seria explicada pela formação acadêmica de Souza Campos como engenheiro agrônomo, já extinta na década de 1910 naquela instituição, que lhe exigiu o estudo das disciplinas básicas somente em nível elementar, característica da formação politécnica do final do século XIX e início do XX. Por essa razão, ele não estaria a par das necessidades técnicas profissionais do engenheiro civil, mecânico, eletricista etc, daquele momento, levando-o a uma visão restrita da questão e aceita pelos outros professores do Conselho Universitário, que estariam nas mesmas condições de compreensão (UM CONFLITO..., 1937, p.28-29).
} 
núcleo a Escola Politécnica e que foi derrotado com a criação da universidade nos moldes da Comunhão paulista. Além disso, estava em jogo o apreço do grupo dos engenheiros por “símbolos, lugares, mestres e pela tradição antiga que representavam, na qual a especulação desinteressada era justamente o que mais caracterizava o 'bacharel' como antípoda do ‘engenheiro politécnico’”. Com a contratação de professores estrangeiros cientistas para as disciplinas fundamentais, os engenheirandos teriam descaracterizado o início de sua formação, recebendo a essência do "espírito universitário" desinteressado em lugar do aplicado "espírito politécnico”.

Se parte do grupo dos professores da Politécnica lutavam para manter, dentro da Universidade, a autonomia didática e simbólica de sua formação técnica, seus opositores trabalham para a criação e consolidação de uma nova tradição científica, a universitária brasileira. Essa tradição, representada no “espírito universitário”, era acalentada não apenas pelo "grupo do Estado", mas por docentes como Amoroso Costa, Theodoro Ramos, Fonseca Telles, Souza Campos e Azevedo do Amaral, retomando uma questão que estava exposta na década de 1920, com a criação da Academia Brasileira de Ciências e as campanhas e inquéritos da $\mathrm{ABE}$ e de OESP.

No campo da matemática, por exemplo, a defesa por parte de alguns professores dos estudos das ciências puras e desinteressadas em contraposição ao pragmatismo técnico estavam intimamente ligadas à crítica a concepção positivista da ciência, dominante na Escola Politécnica do Rio de Janeiro no final do XIX e início do XX (SIQUEIRA, 2017). Ao se manifestarem favoráveis a instituição de uma Faculdade Superior de Ciências, em 1923, como lugar da pesquisa pura e desinteressada,

\begin{abstract}
os membros da $\mathrm{ABC}$ vão além de dizer que não há espaço para esse tipo de prática nas atuais faculdades brasileiras, eles sugerem que a criação, a novidade, a invenção não se faz nelas. Nas décadas seguintes, o novo em oposição ao atraso será um moto contínuo entre os discursos dos professores e estudantes das universidades dos anos 30 (SIQUEIRA, 2017, p.24).
\end{abstract}

No caso da escola fluminense, Siqueira (2017, p.32) aponta que a campanha dos professores das disciplinas teóricas do curso de engenharia por um novo espaço para as ciências puras e desinteressadas correspondia a uma reação ao sentimento de "desprestígio" por eles experimentado, em decorrência da progressiva popularização do título de bacharel em ciências a qualquer formando em engenharia, segundo o regimento de 1925 da Escola Politécnica. Assim, 
pressionados pela desvalorização daquilo que faziam, ao invés de abraçarem a profissionalização da carreira dos engenheiros que despontava no horizonte, parte desses engenheiros procuraram construir um outro espaço institucional. Os ideais de pureza e desinteresse compunham um vocabulário bastante adequado para se opor a um grupo que aspirava se profissionalizar e disputava vagas no mercado de trabalho (SIQUEIRA, 2017, p.32).

Os projetos antagônicos -- ciências puras e desinteressadas versus ciência aplicada e técnica -- desembocaram, no final da década de 1920 e 1930, nas tensões entre a concepção de universidade nucleada na Faculdade de Filosofia e na universidade técnica, razão da resistência dos engenheiros à centralização das cadeiras fundamentais na FFCL no caso paulista e à criação da faculdade de ciências na Universidade do Rio de Janeiro, que acabou não saindo do papel.

No parecer da Congregação da Politécnica, os docentes desejavam a distinção das cadeiras básicas, pois “o desenvolvimento da técnica por um lado e o da ciência por outro, obrigando, cada vez mais acentuadamente, ‘técnicos’ e ‘cientistas’ a uma preparação distinta” apontava a solução mais adequada ao conflito (UM CONFLITO..., 1937, p. 14).

Mesmo tendo como aspiração a universidade técnica alemã, autônoma em relação à universidade do modelo humboldtiano, em última instância não seria possível implantá-la em São Paulo sem seu desligamento da USP, algo apontado por Souza Campos em seu pronunciamento de voto. Se levada a cabo, o projeto de universidade técnica poria fim à consolidação da FFCL e ao projeto da Comunhão paulista. Como alternativa, a congregação propunha manter a separação das cadeiras fundamentais em seu aspecto didático, inclusive na nomeação dos professores, que deveriam antes de tudo ser engenheiros. Para defenderem de forma documentada esse argumento, em ampla crítica ao ensaísmo de Souza Campos em sua declaração, descrita como um “catálogo” de depoimentos colhidos de professores da área em universidades estrangeiras e de experiências de outros países, a Congregação da Politécnica valeu-se dos relatórios do Congresso Internacional do Ensino Técnico, realizado 1910, em Bruxelas, e do inquérito da Society for the Promotion of Engineering Education, de 1934, promovido nos Estados Unidos. Em ambos documentos, os especialistas indicavam como melhor estrutura de formação a união entre técnica e ciência pura, de forma seriada na mesma instituição, na qual o ensino técnico era a base e, para os que desejasse seguir os estudos desinteressados, acrescentavam-se as matérias afins. Dessa forma, seriam formados engenheiros voltados às exigências da indústria e engenheiros voltados às ciências puras, estes por meio de especialização para o doutoramento, enquanto a proposta aprovada pelo Conselho Universitário 
estava baseada no sentido inverso, defendendo a centralização das cadeiras como elemento propedêutico, na contramão da tendência do "consenso moderno, real e universal do ensino da engenharia” (UM CONFLITO..., 1937, p.126).

Mesmo entrando com recurso perante o CNE, em outubro de 1937, e pedindo a impugnação da decisão do Conselho Universitário da USP, o parecer da Comissão de Ensino e Regimentos, assinado pelo diretor da Politécnica Alexandre Albuquerque e pelo professor Altino Antunes foi aceito, pois o órgão federal deliberou que o caso era da jurisprudência da universidade. Por fim, o projeto da formação do "espírito universitário”, voltado à vivência e formação geral dos alunos e professores na FFCL estava salvaguardado. A força centrípeta da FFCL resistiu, sobrepondo-se à temida conglomeração de escolas profissionais, julgada negativamente desde os primórdios da campanha pela universidade na década de 1920.

No relatório de 1938, feito à reitoria da universidade como prestação dos serviços oferecidos a FFCL, Souza Campos (1938b, p.14) confessava: “espero assim ter correspondido à confiança dos que me chamaram para a direção desta Faculdade, em uma hora difícil e perigosa da sua vida ainda não bem consolidada”. Mesmo na esperança de ter apaziguado a situação instável da FFCL, esta ainda continuaria a sofrer com as incertezas sobre seu futuro após as mudanças encetadas com a nomeação de Adhemar de Barros ao cargo de interventor de São Paulo e do bacharel católico Alexandre Corrêa para o cargo de diretor da unidade.

\subsection{A MATERIALIZAÇÃO DO “ESPÍRITO UNIVERSITÁRIO”: A CIDADE UNIVERSITÁRIA}

Entre os anos de 1935 e 1937, Souza Campos foi designado “em missão oficial, [para promover] o estudo de vários problemas relacionados ao ensino médico e às organizações universitárias de São Paulo, da capital da República e outros pontos do país” (CAMPOS, 1938a, p. 17), participando das comissões de organização e localização das cidades universitárias da Universidade do Brasil e da Universidade de São Paulo, assim como dos estudos para a reorganização dos blocos médicos das Faculdade de Medicina da Bahia e de Porto Alegre, reverberando sua autoridade como intelectual especialista em estruturas e espaços universitários, angariada especialmente com a construção da sede da Faculdade de Medicina de São Paulo. Dessa forma, Souza Campos atuou na concretização dos projetos das universidades, 
ao buscar a materialização o “espírito universitário” na elaboração dos planos das cidades universitárias.

\subsubsection{O caso da USP: a primeira fase dos planos}

Em junho de 1935, Reynaldo Porchat convocou Souza Campos para compor a comissão, nomeada pelo interventor Armando de Salles Oliveira, para estudos da localização da cidade universitária da USP, ao lado de Ernesto Leme, da Faculdade de Direito, Alexandre Albuquerque, da Escola Politécnica, Fernando de Azevedo, do Instituto de Educação, Afrânio do Amaral, do Instituto Butantã e Mário de Andrade, diretor do Departamento de Cultura. Reunidos por três meses para debate da questão, apresentaram memorial ao governador com a escolha da área do terreno compreendido entre a Faculdade de Medicina e o Butantã para a construção da cidade universitária (CAMPOS, 1938a, p. 183).

Souza Campos desempenhou papel fundamental na escolha dos terrenos e no conceito geral da cidade universitária.

Tão importante quanto os profissionais específicos voltados para o projeto e obras, foi a participação do professor Ernesto de Souza Campos,[...] defendendo ideias e propondo soluções durante as fases iniciais da localização e planejamento da Cidade Universitária; traçando parte das diretrizes que pautaram a centralização e setorização das unidades universitárias e o programa pedagógico, que são dois dos principais temas que, diretamente, interferiram na escolha da localização, das dimensões da área a ser adquirida e das soluções urbanístico-arquitetônicas da futura Universidade que estava se criando"(CARAM, 2014, p.185-186).

De acordo com a ata da segunda sessão da comissão, Ernesto de Souza Campos demonstrou a

necessidade de uma área ampla para a localização da Universidade, justificando seu ponto de vista no futuro desenvolvimento de São Paulo e da Universidade. Apresenta, ainda, à consideração da Comissão dados relativos às áreas de vinte e oito universidades norte-americanas com a lista de seus institutos componentes, sugerindo a área de 100 alqueires para a Universidade de São Paulo e demonstrando ser já escassa a área presentemente reservada à Faculdade de Medicina para a realização de seu programa completo (CAMPOS, 1938a, p. 185-186).

A referência ao campus norte-americano para o plano da cidade universitária da USP é explícito. De acordo com Pinto e Buffa (2009) e Caram (2014), a formação do espaço 
universitário em formato de campus $^{128}$ é uma criação genuinamente norte-americana, que advém da formação de seu ensino superior baseado nos colleges do modelo inglês, somada às transformações geradas pela expansão territorial e industrialização do país durante o século XIX, marcadamente após a instituição do Morril Act (1862) no contexto da Guerra Civil, que legou aos estados financiamento e o uso de lotes de terras públicas para a construção das instituições universitárias voltada aos estudos militares, de agricultura e artes mecânicas (COHEN,1998, p.107).

A noção de campus se consolidou no planejamento dos espaços universitários nos EUA que, por estar afastado da cidade, permitia a fruição de um ambiente adequado para as práticas acadêmicas. O modelo de ocupação tipo campus, desenvolvido e adotado em várias universidades dos Estados Unidos, vem servindo de referência para a implantação de universidades da Europa, América Latina, assim como no Brasil (CARAM, 2014, p.51).

O campus surgiu nos EUA para abrigar um novo modelo de configuração espacial na implantação dos college desde o século XVII, que negavam sua origem nos claustros fechados do modelo inglês e que consideravam os "limites da cidade ou mesmo o próprio campo o local ideal para instalação do complexo acadêmico. [...] Na América, os colleges foram implantados nos limites da cidade, muito mais do que nas áreas centrais urbanizadas” (CARAM, 2014, p.58). Com a expansão do número de instituições acadêmicas no século XIX, arquitetos passaram a dedicar-se em concepções espaciais mais apuradas em relação às demandas educacionais das instituições. Este foi o caso do projeto do campus da Universidade de Virgínia, em Charlottesville, projetado por Thomas Jefferson, em 1817, que configurou um avanço no modo de se implantar os espaços desse tipo de ensino e estabeleceu um padrão de universidade que serviu de referência para os projetos de colleges e universidades estadunidenses, conhecidas como "American village green” ou "academical village", constituído por um formato de college estendido, com casa dos professores, centro da biblioteca, pátio verde, e ensino universitário laico (CARAM, 2014, p. 61- 62).

\footnotetext{
${ }^{128}$ Apesar de existir uma diferença conceitual e histórica em relação a palavra campus, ligada a ideia de espaço campestre, e a expressão cidade universitária, diretamente relacionada à infraestrutura urbana (PINTO; BUFFA, 2009), "na prática brasileira, não há muitas distinções entre o conceito de cidade universitária e campus universitário, visto que no planejamento do espaço universitário foram utilizados os paradigmas do urbanismo, recorrentes nas primeiras décadas do século XX”(CARAM, 2014, p.122). Utilizamos, portanto, as duas formas como sinônimos.
} 
A relação harmônica entre homem e natureza permaneceu nos campi universitários norte-americanos, formados em espaços longe da agitação das cidades e com possibilidade de ampliação interna. Mesmo com a crescente urbanização e o encampamento pelas cidades, a interação entre arquitetura, edifícios, arte e natureza transfigurou-se em um modelo onde o campus situava-se em um local nem totalmente rural, longe da civilização, nem no meio da cidade, com suas distrações. Estava no entremeio, como um lugar para o tipo certo de pessoa promover um refinado e moral estilo de vida, integrado ao entorno urbanizado, resguardando o caráter campestre e de parque predominante na paisagem interna do campus (CARAM, 2014, p.68). "Esse ideal é tão forte nos EUA que mesmo as escolas localizadas nas cidades, onde a terra é mais escassa, procuram áreas que simulem, de alguma forma, com muito verde, um rio ou um lago, uma especialidade rural” (PINTO; BUFFA, 2009, p.38-39).

Mesmo antes do movimento da arquitetura moderna, que no início do século XX acabou por trazer novas relações para planejamento dos complexos universitários nos Estados Unidos e Europa, a concepção do conceito de campus constitui um território privilegiado, com desenhos urbanos distintos da cidade que o cerca. "Tais soluções (tradicionais ou modernas) vem influenciando o planejamento urbano e arquitetônico de universidades em várias partes do mundo, incluindo o Brasil, no processo de concepção e construção de suas primeiras cidades universitárias, a partir da década de 1920” (CARAM, 2014, p. 72).

Conforme Souza Campos (1938b, p. 118-121), a localização ideal da cidade universitária deveria corresponder a uma área de grande extensão, dividida em setores, de acordo com as áreas de conhecimento, onde a FFCL seria o setor nuclear, relembrando a tese apresentada por Álvaro Ozório de Almeida no período da campanha pela universidade, capaz de abranger, dentro de um mesmo campus, todas as organizações de educação e pesquisa e institutos auxiliares, garantindo a centralização como fator indispensável à viabilização didática e física da universidade. Por isso, era imperativo deslocá-la dos centros urbanos, mas mantendo uma proximidade por conta da fácil comunicação, indispensável aos cursos de extensão universitária. Outro fator preponderante para que a cidade universitária mantivesse uma conexão com a zona urbana era o setor médico, que deveria estar disponível à população, em clara alusão à manutenção do prédio da Faculdade de Medicina por ele projetado dentro dos limites do campus.

A referência mais evidente da comissão eram as instalações de algumas universidades norte-americanas. Era clara a intenção de não separar duas unidades já instaladas e em funcionamento: o Instituto Butantã, ao lado 
do Rio Pinheiros, e o Complexo Médico, no alto do Araçá, na outra extremidade (PINTO; BUFFA, 2009, p.76).

Encerrada a fase dos estudos da localização, foi dado andamento ao segundo estágio, relativo à organização do plano geral e das primeiras unidades da cidade universitária, efetuado pelo Escritório Técnico presidido por Antonio de Almeida Prado, diretor da FFCL e vice-reitor, dirigido e orientado por Ernesto de Souza Campos, com Hyppolito Gustavo Pujol Jr. como arquiteto chefe. A efetivação do plano escolhido pela comissão, no entanto, não se tornou possível, pois seria necessário desapropriar parte dos terrenos da Companhia City, que negou a negociação com o governo, levando o caso à Assembleia Legislativa. Após outros estudos para resolver a questão, chegou-se à "Solução Butantã”, área que compreende atualmente o campus, sem a ligação direta com o bloco da Medicina no Araçá (CARAM, 2014, p.196). Quanto a formação arquitetônica dos prédios,

a proposta dos pavilhões foi uma das primeiras abordagens em relação à
forma a ser adotada nas unidades acadêmicas da Universidade. Mas, no
decurso dos debates e realizações, o plano da Cidade Universitária
aglutinou várias propostas e projetos que representam culturas, ideias e
épocas diferentes, não se fixando apenas num modelo de ocupação
(CARAM, 2014, p.186).

Mesmo com a protelação das decisões referentes ao terreno e a interrupção dos trabalhos do escritório técnico, que teve seu projeto engavetado após a instauração do Estado Novo, até serem retomados e reformulados a partir de 1941, os primeiros planos para a cidade universitária da USP configuraram, segundo Souza Campos (1954) a primeira fase de elaboração e construção da cidade universitária, criando as diretrizes mestras sob as quais outros projetos iriam se sobrepor ao longo de três décadas de processos de construção descontínuos.

\subsubsection{Projeto educacional versus projeto arquitetônico: disputas no caso da UB}

No Rio de Janeiro, a atuação de Souza Campos junto ao Ministério da Educação foi intensa e decisiva. Ainda nos trabalhos iniciais da Comissão de Estudos do Plano da Universidade do Brasil, Capanema indicou Souza Campos para fazer parte de uma subcomissão, a Comissão de Organização do Plano da Universidade, responsável pelo projeto arquitetônico da cidade universitária, junto a Lourenço Filho, Jônatas Serrano e Azevedo do Amaral. Também foi indicado para a direção do Escritório Técnico do Plano da Universidade, 
ao lado de Inácio Azevedo do Amaral, para agirem em nome da COPU. Conforme Gustavo Capanema defendeu, em discurso na sessão de instalação solene da comissão do plano da Cidade Universitária, o projeto de construção física da universidade quase se confundia com a elaboração dos planos de seus cursos e institutos, e por essa razão ambas as atividades deveriam ser desenvolvidas pela mesma comissão de professores (SCHWARTZMAN; BOMENY; COSTA, 1984, p.96-97). Espaço e programa deveriam ser concebidos de forma unificada, entrelaçadas em prol da formação universitária.

Esta concepção estava muito próxima do projeto proposto por Souza Campos na construção do prédio da Faculdade de Medicina, desenvolvido nos moldes do programa curricular reformulado pela instituição, segundo o padrão de excelência exigido para a doação da Fundação Rockefeller, garantindo que os espaços físicos fossem condizentes com as necessidades do ensino e da pesquisa. Conforme o próprio Souza Campos (1938a, p. 307), Gustavo Capanema o teria escolhido para a comissão por ser um "nome que se tornou conhecido no Brasil inteiro pela sua capacidade em matéria de construção de escolas de medicina, pelo trabalho que realizou nesse sentido em S. Paulo e pelos estudos preciosíssimos que fez neste sentido".

Com um projeto de formação superior para as elites, a concepção universitária defendida pelo governo federal se assemelhava ao projeto da universidade paulista, centrada nos objetivos de criar a Faculdade de Filosofia, Ciências e Letras, construir o campus universitário e formar uma elite intelectual condutora da cultura nacional. Para Schwartzman, Bomeny e Costa (1984, p.209), a Universidade do Brasil seria uma universidade para a elite, assentada em uma “Cidade Universitária construída em moldes grandiosos, que fosse, ao mesmo tempo, o núcleo da cultura brasileira e o marco mais visível da passagem de Gustavo Capanema pelo Ministério da Educação”. Apesar da grande expectativa, os conflitos acerca da produção arquitetônica da cidade universitária da UB tomou proporções internacionais e acabou ganhando uma dimensão ampliada em relação ao planejamento curricular dos cursos. Estas disputas, protagonizadas por Souza Campos, teriam prejudicado o próprio andamento do projeto da cidade universitária, que acabou abortado em 1939 e somente retomado em diferente contexto, nos anos 1950.

Os conflitos ocorrem sobre a escolha do terreno e a disputa dos projetos arquitetônicos efetuados pelos arquitetos Marcello Piacentini, convidado por Capanema para desenhar o projeto nos moldes da novo campus da Universidade de Roma, e Le Corbusier, apoiado por um grupo de arquitetos cariocas que se filiaram ao seu trabalho. De acordo com Schwartzman, 
Bomeny e Costa (1984), durante a atuação da comissão dos professores na construção do projeto da Cidade Universitária da UB, houve uma polêmica quanto à produção e controle do projeto entre a comissão de professores e as entidades representativas dos arquitetos, liderados por Lúcio Costa. A comissão dos professores universitários, juntamente com Piacentini, recebeu forte reação dos arquitetos e engenheiros nacionais ligados ao estilo moderno corbusiano, grupo que pressionou o ministério para a criação de uma comissão paralela de profissionais da área e pelo convite a Le Corbusier para ser o idealizador do projeto do campus. Conforme apontaram Lissovsky e Sá (2000, p. 53), “a renhida luta por audiência e espaços de afirmação social travada entre correntes artísticas costumava acentuar-se quando o objeto de disputa estava de alguma forma relacionado ao Estado”. De fato, o que estava exposto nessa disputa era por um lado o controle do projeto da cidade universitária por dois engenheiros que não eram do ramo da arquitetura (Souza Campos e Azevedo do Amaral), mas que se colocavam como conhecedores dos termos técnicos dos projetos ao mesmo tempo que se julgavam pertencentes ao grupo dos educadores que compreendiam os princípios educacionais do Plano da Universidade como projeto político-pedagógico; e por outro os arquitetos modernos, que buscavam junto ao Estado uma oportunidade de institucionalização da arquitetura moderna como "brasileira”, expressando sua ascensão no campo da arquitetura.

A princípio, o terreno indicado para a construção do campus da UB era no bairro Praia Vermelha. No entanto, Souza Campos relata que via a área como diminuta, e que teria de ser expandida, gerando assim uma despesa considerável. Por esta razão, outras opções foram aventadas, sendo na Gávea, Leblon, Mangueira e Quinta da Boa Vista. Marcello Piacentini, presente no Brasil em agosto de 1935, examinou os terrenos propostos e projetou traçados urbanísticos para a cidade universitária para todas as opções, mas mostrou-se favorável ao projeto da Praia Vermelha, primeiramente, e em seguida, pelo da Quinta da Boa Vista. A comissão do escritório apresentou ao ministro as considerações do arquiteto, propondo sugestões para o andamento dos trabalhos para a escolha do terreno. Em janeiro de 1936, as propostas definitivas foram apresentadas à comissão dos professores e a proposta da Quinta da Boa Vista foi aprovada pela maioria (CAMPOS, 1938a, p. 314-318).

Em seguida ao levantamento topográfico do terreno, passou-se à elaboração dos programas das faculdades que comporiam a universidade. Dirigida por Souza Campos e Azevedo do Amaral e composta por mais dois engenheiros, a subcomissão responsável pelo plano de organização da cidade universidade obedeceu às seguintes diretivas: 
A sub-Comissão julga dever propor a definição dos seguintes princípios, em que se consubstanciam os resultados da observação e da experiência do seu presidente o professor Souza Campos nas investigações a que procedeu para a organização e constituição da Faculdade de Medicina da Universidade de São Paulo, e suas dependências, visitando e estudando mais de duzentas Universidades e institutos de todos os pontos do mundo. [...] 3 - A eficiência do sistema, porém, exige duas providências fundamentais. A fixação do número de alunos, sem a qual será impossível criar qualquer organização didática e construtiva, e a adoção de princípios do "tempo integral"[...]. 4 - O planejamento material da Universidade depende pois, do número de alunos e de professores e auxiliares, convindo assinalar que a adoção do regime de "tempo integral” exige um aumento de área, pela necessidade de espaço para instalações adequadas às pesquisas, permanentemente realizadas (CAMPOS, 1938a, p.322).

Explicitamente, Souza Campos tentou imprimir as diretivas e os princípios que deveriam guiar os programas e a construção das faculdades da universidade. Esse controle derivava da experiência anterior na Faculdade de Medicina de São Paulo, durante sua colaboração com a Fundação Rockefeller para os estudos e construção do prédio. A referência está igualmente clara na defesa do tempo integral de dedicação dos docentes e da adequação dos espaços das instalações conforme as necessidades do ensino e da pesquisa, em formato de departamentos, conforme o modelo Rockefeller. Seguindo essa lógica, a quantidade de departamentos, laboratórios, salas de serviços e número de alunos eram os pontos de partida para o planejamento do espaço almejado. O espaço deveria estar a serviço das demandas da formação. Para Mendonça (2002, p.128-129), Souza Campos tentou também interferir, de forma infrutífera, no processo de organização da Faculdade de Filosofia, que corria de forma paralela ao plano global da universidade, persuadindo Gustavo Capanema a incorporar no projeto da UB “sua concepção de universidade integrada a partir da Faculdade de Filosofia, Ciências e Letras -- célula máter da instituição --, cerne da concepção da USP”.

Posteriormente à fase dos programas, passou-se ao estudo dos projetos de urbanização, assunto de disputa com os arquitetos. No livro de Souza Campos (1938a), o relato sobre as oposições aparece de forma sutil. No entanto, cruzando as informações com outros documentos do arquivo de Gustavo Capanema e obras historiográficas é possível detectar que o conflito ganhou proporções que contribuíram para o adiamento dos trabalhos. "Por constituir-se um desafio simultaneamente monumental e urbanístico, a contenda em torno dela [cidade universitária] foi ainda mais acirrada que a da sede do ministério” (LISSOVSKY; SÁ, 2000, p.55). 
As entidades de classe de engenharia e arquitetura protestaram contra a contratação do arquiteto estrangeiro Marcello Piacentini, argumentando que o ato contrariaria a ética e a legislação em vigor no que se referia a edificações públicas. No entanto, para conseguir a colaboração de Piacentini, o ministério teria requerido seu trabalho por meio do formato de “consulta técnica”. Após o primeiro momento de reação à vinda do italiano, o ministério solicitara a colaboração de arquitetos nacionais para formar uma equipe por meio de representantes do Instituto Central dos Arquitetos, do Clube de Engenharia e do Sindicato dos Engenheiros. Entre os indicados estava Lúcio Costa, principal articulador entre Le Corbusier e o ministério e defensor de seu estilo arquitetônico no Brasil (LISSOVSKY; SÁ, 2000, p.55-56). A contenda inicia-se no ponto referente à localização do terreno. Lúcio Costa não se satisfaz com o terreno da Quinta da Boa Vista, que não teria vista para o mar. Para substituí-lo, sugere que a cidade universitária fosse criada sobre a lagoa Rodrigo de Freitas, ideia que o ministro temeu tornar-se um escândalo na imprensa (LISSOVSKY; SÁ, 2000, p.55). Conforme o relatório de Souza Campos (1938a, p.325-326), os arquitetos escolhidos realizaram várias reuniões com os diretores do escritório para tomar conhecimento dos trabalhos realizados, que constavam nos programas descritivos e gráficos já elaborados pela comissão especial, para poderem desenvolver seus trabalhos na solução arquitetônica e urbanística na cidade universitária. Inicialmente, deveriam fazer o projeto de urbanização, zoneamento e terraplenagem, para depois começarem os estudos dos projetos de cada unidade universitária. O Escritório do Plano da Universidade já havia estabelecido dois planos de urbanização e zoneamento e a composição geral do maior número das unidades do complexo universitário, apresentados como subsídios para o estudo definitivo, ao lado dos esboços de Piacentini. Entretanto, a comissão dos arquitetos apresentou a proposta da lagoa Rodrigo de Freitas, no qual todos os edifícios ficariam sobre estacas e seriam ligados por meio de pontes. Para Souza Campos e Azevedo do Amaral, a proposta apresentava objeções técnicas decisivas, além do que, a escolha do terreno já havia sido feita em processo anterior. Desaprovada a proposta dos arquitetos, estes solicitam ao ministério a vinda de Le Corbusier ao Brasil, sob a nomeação oficial de convidado para um ciclo de conferências. (CAMPOS, 1938a, p. 327). Nas palavras de Le Corbusier, em carta endereçada ao ministro Gustavo Capanema, a proposta é negada: “estou em uma idade que não mais me permite deslocar para tão longe pura e simplesmente para dar conferências a estudantes. É-me indispensável que eu possa criar obras arquitetônicas pequenas ou grandiosas, mas significativas” (apud LISSOVSKY; SÁ, 2000, p.53). 
Fica evidente que a comissão dos arquitetos chefia por Lúcio Costa tentara barganhar junto ao ministério a possibilidade da mudança do terreno para a criação de uma obra moderna de grande impacto nacional e internacional. Queriam aproveitar o momento para emplacar a arquitetura moderna no Brasil por meio de uma obra pública, buscando dispor um marco na arquitetura, que garantiria sua legitimidade no campo (LISSOVSKY; SÁ, 2000).

As diferentes motivações que regiam os planos das duas comissões era explorado como argumento definitivo da supremacia do projeto dos professores. Conforme ofício de Souza Campos ao ministro, diversas vezes foi salientado que o "problema de composição do organismo universitário é de ordem educativa. As questões de arquitetura estão em plano inferior e principalmente no que diz respeito aos de doutrina arquitetônica” (apud SCHWARTZMAN; BOMENY; COSTA, 1984, p.207). A celeuma entre as comissões havia atingido o debate público, o que levou Souza Campos a publicar na imprensa um artigo anônimo, explicando os princípios que regiam o projeto da cidade universitária:

Estamos diante de um problema educativo e não de um problema urbanístico. Não se construiria uma Universidade somente para dar relevo e embelezamento a uma cidade. Para esta obra concorrem todos os brasileiros e o que eles devem desejar é que se constitua um centro de estudos moderno e eficiente. Edifícios amplos e bem aparelhados e de custo razoável. Não uma Universidade para mostrar ao estrangeiro e sim para educar o nosso povo. O urbanismo deve entrar na composição do programa com elemento conveniente ou mesmo de caráter indispensável, porém não como fator primordial. Universidade produtiva e não decorativa é o que precisamos ${ }^{129}$.

Tal visão era condizente com as experiências vivenciadas por Souza Campos com o escritório de Ramos de Azevedo, conhecido por suas obras funcionais de estilo eclético. Souza Campos argumentava junto a Azevedo do Amaral que para a cidade universitária a escolha deveria recair sobre um tipo de construção simples e destituída de elementos decorativos de custo elevado, e não “mirabolante” e “irrealizável” como o projeto Le Corbusier, acreditando que "resultam dessas condições a fadiga dos que realmente estão empenhados no problema, o desânimo dos que nele punham alguma esperança, o fortalecimento dos que, por qualquer motivo, combatem a iniciativa e finalmente um gasto improfícuo de somas” ${ }^{\text {130 }}$. As sutilezas dos

\footnotetext{
${ }^{129}$ O Jornal. A localização da Cidade Universitária (de um observador), 18 de abril de 1936 [Fundo Ernesto de Souza Campos, Curriculum Vitae, Vol.VI].

${ }^{130}$ Carta de Ernesto de Souza Campos a Inácio Azevedo do Amaral, 18 de setembro de 1936 [Fundo Ernesto de Souza Campos, Curriculum Vitae, Vol.VI].
} 
conflitos não passavam, no entanto, somente pelo viés estilístico. Para o arquiteto chefe dos projetos escolares anisianos do Distrito Federal, Enéas Silva,

baseado no estudo profundo dos objetivos educacionais, sociais e recreativos da instituição, o plano de desenvolvimento do campus representa, ao mesmo tempo a substância de um ideal e o plano diretor para a execução desse ideal. É óbvio concluir, portanto, que o plano diretor para a construção de uma Universidade contemporânea, não poderá ser concebido através do mesmo partido arquitetônico adotado em Universidades construídas no século passado ${ }^{131}$.

A crítica era endereçada ao projeto de Piacentini em Roma, inspirado na manutenção do formato de fórum das praças quinhentistas e da adoção do quadrângulo norte-americano dos antigos colleges, que por serem uma estrutura fechada não correspondiam às necessidades do organismo vivo da universidade moderna. Para ele, somente um partido arquitetônico novo, ou seja, o moderno, poderia representar os novos processos educativos. A mesma crítica vinha de Le Corbusier, que em carta a Capanema afirmava estar "persuadido de que a imitação da concepção americana de universidades é um erro, e que as teses que enunciei em meus estudos são realmente as que convêm a um empreendimento de espírito moderno" (apud SCHWARTZMAN; BOMENY; COSTA, 2000, p.368). Além da polarização vivenciada pelas duas comissões, de acordo com Caram (2014, p.305),

desta fase de intensa elaboração projetual da equipe de arquitetos, professores, e pelo arquitetos estrangeiros, surgiu também um projeto alternativo elaborado pelo engenheiro-arquiteto Pujol Júnior e pelo professor Ernesto de Souza Campos, que pouco foi explorado na crítica historiográfica sobre os diversos planos desenvolvidos para a Universidade do Brasil. Este projeto, embora também não executado, corrobora com a tese de que a concepção das primeiras universidades seguia influências das cidades-jardins, provando quão forte foi essa tendência de urbanismo que serviu de base e inspiração para a elaboração de planos de cidades, bairros e campi universitários. Desenhado por Pujol, este plano serviu de inspiração para o projeto do concurso vencedor para a Cidade Universitária da USP, em 1945.

Eliminado o projeto de Le Corbusier, a comissão de arquitetos, agora integrada por Oscar Niemeyer, apresenta um anteprojeto sob a orientação do “mestre” para a área da Quinta da Boa Vista, que foi rejeitado definitivamente pela comissão de professores em fevereiro de 1937. Somado aos impasses entre a comissão dos professores e a comissão dos arquitetos, a imprensa fluminense repreendeu duramente o plano da cidade universitária, com destaque aos

\footnotetext{
${ }^{131}$ O Correio da Manhã, 19 de julho de 1936 [Fundo Ernesto de Souza Campos, Curriculum Vitae, Vol.VI].
} 
discursos dos deputados Figueiredo Rodrigues e Gomes Ferraz endereçado ao Senado Nacional, por conta de questões que envolviam a desapropriação de terrenos em área urbana e pela própria monumentalidade do projeto educacional de Capanema, em tempos de crise financeira (UNIVERSIDADE..., 1937, p.3-6).

Em 1939, por questões políticas e técnicas, as atividades das comissões foram definitivamente encerradas e ambos os projetos foram arquivados. O grupo dos arquitetos voltou a barganhar com o Estado pela construção do edifício do Ministério da Educação e Saúde, que acabou ficando para a posteridade como a grande obra moderna brasileira da década de 1940 .

Tanto no caso da cidade universitária da USP (CAMPOS, 1954) quanto da UB (MENDONÇA, 2002, p.128), Souza Campos permaneceu envolvido nos projetos e embates com os arquitetos modernos durante as duas décadas seguintes, em um novo contexto político, econômico, cultural e social que transformaram os projetos originais de ambas universidades em seu período de idealização e criação, nas décadas de 1920 e 1930. 


\section{CONSIDERAÇÕES FINAIS}

Dados o enquadramento desta pesquisa no campo da História da Educação e a complexidade das relações de Ernesto de Souza Campos no mundo da elite intelectual paulista, construídas tanto por sua origem familiar quanto por seu pertencimento à instituições científicas e de debate público, a presente tese teve como objetivos apresentar e analisar a trajetória intelectual de Ernesto de Souza Campos desde suas formações acadêmicas até por sua atuação na causa das universidades nas primeiras metade do século XX, suas concepções educacionais e vinculações com projetos políticos de educação superior de setores do elite paulista e do governo estadonovista, a partir da participação na elaboração do prédio da Faculdade de Medicina, do campus da Universidade de São Paulo e da Universidade do Brasil. Comprovamos que sua ação intelectual foi relevante para a implementação de aspectos de modelos universitários estrangeiros em instituições de ensino superior brasileiras entre as décadas de 1920 e 1930, marcadamente o norte-americano, com o qual teve contato durante seu estágio de especialização como bolsista da Fundação Rockefeller e nas viagens como comissionado pela mesma instituição para estudos dos modelos médicos e universitários. Por meio de apropriações desses elementos, Souza Campos enredou-se na elaboração do aspecto “espiritual” da universidade, ou seja, da idealização conceitual, e no aspecto material, com a consolidação do projeto universitário em uma cidade universitária.

Neste itinerário, Souza Campos utilizou-se de conhecimentos técnicos e simbólicos adquiridos nas formações em engenharia e medicina como instrumentos para seu engajamento na “causa educacional”, considerada indispensável para a instauração da modernidade no país, aproximando-se do poder político como especialista em ensino superior e, capaz de estabelecer as diretrizes dos projetos político-pedagógicos dos governos para os quais trabalhou. Em consonância com o ambiente de discussão intelectual da década de 1920 e 1930, promoveu o que defendeu como conceito brasileiro de universidade, caracterizado por uma formação híbrida do modelo alemão e francês no tocante a formação da FFCL e o norte-americano, especificamente quanto ao conceito de campus universitário.

Este estudo não teve por finalidade legitimar uma interpretação das ações de Souza Campos como idiossincrasias ou emanações de um espírito visionário, mas como elementos que compuseram o debate público, os jogos políticos institucionais e a constituição da história dessas 
instituições, proveniente de sua inserção em grupos da elite intelectual paulista e federal, diretamente ligadas a relações acadêmicas, sociais, políticas e institucionais.

Para alcançar o objetivo da pesquisa, abarcamos aspectos de sua biografia, das relações por ele mantidas nos círculos sociais e profissionais, dos contextos políticos, culturais e institucionais em que esteve inscrito, por meio do diálogo com a historiografia do ensino superior brasileira e norte-americana, com documentos institucionais nacionais e internacionais e da imprensa, com a finalidade de compor e compreender o ambiente em que viveu e desenvolveu sua trajetória intelectual, na busca por delinear as dimensões das ações históricas de nossa personagem no ensino superior brasileiro. Assim como outros intelectuais de seu tempo, Souza Campos, engenheiro e médico, foi um "apóstolo" da causa da universidade, um educador, ideólogo e especialista em modelos, projetos e espaços universitários nos anos 1920 e 1930. 


\section{FONTES}

ALMEIDA, A. O. A organização universitária e as Faculdades de Sciências e Letras. In: ASSOCIAÇÃO BRASILEIRA DE EDUCAÇÃO. O problema universitário brasileiro. Rio de Janeiro: Encadernações S. A., 1929, p.126-157.

ASSOCIAÇÃO BRASILEIRA DE EDUCAÇÃO. O problema universitário brasileiro . Rio de Janeiro: Encadernações S. A., 1929.

BRASIL. Decreto Federal n.o 19.851, de 11 de abril de 1931. Disponível em: $<$ http://www.planalto.gov.br/ccivil_03/decreto/1930-1949/D19851.htm>. Acessado em 08 nov. 2016.

CAMPOS, E. S. Doença de Rustizky-Kahler (Myeloma). São Paulo: Faculdade de Medicina e Cirurgia de São Paulo,1919.

.Educação Superior no Brasil. Rio de Janeiro: MESP, 1940.

.Estudos sobre o problema universitário. São Paulo: Revista dos Tribunais,1938a.

. Fundo Ernesto de Souza Campos, Curriculum Vitae, Vol. I ao VI.

.História da Universidade de São Paulo. São Paulo: Saraiva,1954.

.Meio século de trabalho de Ernesto Souza Campos . São Paulo: Saraiva, 1956.

.Memorial apresentado à Faculdade de Medicina e Cirurgia de S. Paulo pelo Dr. Ernesto de Souza Campos. São Paulo, 1923.

.Um ano de administração na Faculdade de Filosofia, Ciências e Letras da Universidade de São Paulo (junho de 1937 - junho de 1938). São Paulo: Revista dos Tribunais, 1938b.

ESCOLA POLITÉCNICA. Ernesto de Souza Campos. Pasta n. 689, 1900.

ESCOLA POLITÉCNICA. Regulamentos da Escola Polytechica de São Paulo de 1897 a 1935. São Paulo, [1935?].

ESCOLA POLYTECHNICA DE SÃO PAULO. Annuario da Escola Polytechnica de São Paulo para o anno de 1906. São Paulo: Typographia do Diário Oficial, 1906.

ESCOLA POLYTECHNICA DE SÃO PAULO. Annuario da Escola Polytechnica de São Paulo para o anno de 1907. São Paulo: Typographia Brazil, 1907.

FOLHA DA MANHÃ. As inspiradoras dos paulistas de ontem e de hoje. A geração atual da família Sousa Campos. São Paulo, 3 de maio de 1953, s/p. [Fundo Ernesto de Souza Campos] 
JOHNS HOPKINS UNIVERSITY. The Johns Hopkins University School Of Medicine (1893-1943). Baltimore: Johns Hopkins University, 1943.

SÃO PAULO (ESTADO). Secretaria de Estado da Educação e da Saúde Pública . Decreto no 6.283 de 25 de janeiro de 1934. Cria a Universidade de São Paulo e dá outras providências. Disponível em $\quad<\quad$ http://www.leginf.usp.br/?historica=decreto-n-o6-283-de-25-de-janeiro-de-1934>. Acessado em: 12 nov. 2012.

UM CONFLITO entre a congregação da Escola Polytechnica e o Conselho Universitário da Universidade de São Paulo perante Conselho Nacional de Educação. São Paulo: Revista dos Tribunais, 1937.

UNIVERSIDADE DO BRASIL E CIDADE UNIVERSITÁRIA AO SENADO FEDERAL, Rio de Janeiro: Jornal do Comércio, 1937.

ROCKEFElLer ARCHIVE CENTER. 305A Sao Paulo Faculty of Medicine- Sao Paulo Historical Records.

ROCKEFELlER ARCHIVE CENTER. Medical Commission to Brazil. "Medical Education in Brazil”. 


\section{REFERÊNCIAS BIBLIOGRÁFICAS}

ACADEMIA DE MEDICINA DE SÃO PAULO. João Alves de Lima. Disponível em: <http://www.academiamedicinasaopaulo.org.br/biografias/74/BIOGRAFIA-JOAO-ALV ES-DE-LIMA.pdf>. Acessado em: 21 jan. 2017.

ACADEMIA DE MEDICINA DE SÃO PAULO. Sérgio de Paiva Meira (1857-1917). Disponível em: <http://www.academiamedicinasaopaulo.org.br/biografias/178/BIOGRAFIA-SERGIOFLORE NTINO-DE-PAIVA-MEIRA.pdf>. Acessado em: 4 de outubro de 2016.

ALONSO, A. Ideias em movimento: a geração de 1870 na crise do Brasil-Império. São Paulo: Paz e Terra, 2002.

ALVES, C. Jean-François Sirinelli e o político como terreno da história cultural. In: LOPES, E. M. T.; FARIA FILHO, L. M. Pensadores sociais e História da Educação II. Belo Horizonte: Autêntica, 2012, p.111-133.

ANDRADE, R. O. Benvenuti, doutores. Revista Pesquisa Fapesp, 2017. Disponível em:

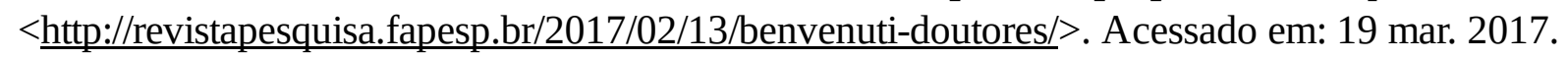

ANTUNHA, H. C. G. Universidade de São Paulo: Fundação e reforma. São Paulo: MEC; INEP; CRPE-SU, 1974.

BOBBIO, N. Os intelectuais e o poder. NOGUEIRA, M. A. (trad.).São Paulo: UNESP, 1997.

BONTEMPI Jr., B. A cadeira de História e Filosofia da Educação da USP entre os anos 40 e 60: um estudo das relações entre a vida acadêmica e a grande imprensa, 2001. Tese (Doutorado). Pontifícia Universidade Católica de São Paulo, São Paulo. 2001.

As sessões solenes da Faculdade de Filosofia: rituais da comunidade intelectual uspiana. Estudos Ibero-Americanos, PUCRS, v. XXXIV, n. 2, p. 168-187, dez., 2008.

Do Instituto de Educação à Faculdade de Filosofia da Universidade de São Paulo. Cadernos de Pesquisa. Vol. 41, n. 142, jan./abr. 2011a, p.188-207.

Escola Politécnica de São Paulo: produção da memória e da identidade social dos engenheiros paulistas. História da Educação [online]. Porto Alegre: UFRGS, V. 19, n. 46 mai/ago, 2015, p.223-242.

História e memória das elites das escolas superiores de São Paulo. São Paulo, 2016. Relatório científico final- FAPESP.

.O espírito decretado e os outros espíritos: tradições e mitologias conflitantes na Universidade de São Paulo (1934-1968). São Paulo, 2011b. Projeto de Pesquisa CNPq/FAPESP/FEUSP. 
.O Estado de S. Paulo e a Faculdade de Filosofia, Ciências e Letras da Universidade de São Paulo: o pensamento educacional convergente. Revista do Mestrado em Educação. São Cristóvão: UFS/NPGED, Vol.4, jan./jun, 2002, p.25-34.

Nacionalismo e regionalismo em dois inquéritos sobre o ensino superior brasileiro nos anos 1920. São Paulo, 2017. No prelo.

BOURDIEU, P. Os usos sociais da ciência: por uma sociologia clínica do campo científico. São Paulo: UNESP, 2004.

BUENO, B. P. S. Escritório Técnico Ramos de Azevedo, Severo \& Villares: longevidade, pluralidade e modernidade (1886-1980). Revista CPC, São Paulo, n.19, p.194-214, jun. 2015.

CAMPOS, N. Encontros e desencontros no processo de constituição do ensino superior no Paraná. In: Revista Brasileira de História da Educação, nº 21, p. 93-122, set./dez. 2009.

CARDoso, I. R. A universidade da Comunhão Paulista: O projeto de criação da Universidade de São Paulo. São Paulo: Editores Associados; Cortez, 1982.

CARVALHO, M. M. C. Molde nacional e fôrma cívica: higiene, moral e trabalho no projeto da Associação Brasileira de Educação (1924 -1931).Bragança Paulista: EDUSF, 1998.

; PINTASSILGO, J. Modelos culturais, saberes pedagógicos, instituições educacionais: Portugal e Brasil, histórias conectadas. São Paulo: EDUSP, 2011.

CARAM, A. L. B. Arquitetura e educação superior: projetos e realizações dos engenheiros-arquitetos da Poli. 2014. 392p. Dissertação (Mestrado em História e Fundamentos da Arquitetura e do Urbanismo) - Faculdade de Arquitetura e Urbanismo, Universidade de São Paulo, São Paulo. 2014.

CASA DE OSWALDO CRUZ/ FIOCRUZ. Laboratório de Bacteriologia do Estado de São Paulo. In: Dicionário Histórico-Biográfico das Ciências da Saúde no Brasil (1832-1930). Disponível em: <http://www.dichistoriasaude.coc.fiocruz.br/iah/pt/verbetes/labbacesp.htm>. Acessado em: 17 nov. 2016.

CATROGA, F. Os modelos de universidade na Europa do século XIX. In: CARVALHO, M. M. C.; PINTASSILGO, J. Modelos culturais, saberes pedagógicos, instituições educacionais: Portugal e Brasil, histórias conectadas. São Paulo: EDUSP, 2011.

CELESTE FILHO, M. Os primórdios da Universidade de São Paulo. Revista Brasileira de História da Educação. v.9, n. 1, p. 187-204, jan./abr. [19], 2009.

CENTRO ACADÊMICO OSWALDO CRUZ. Revista de Medicina, ano 13, $2 .^{\circ}$ sem. 1929, n. 5. Disponível em: <http://www.obrasraras.usp.br/xmlui/handle/123456789/4305>. Acessado em: 15 abr. 2017. 
CERASOLI, J. A grande cruzada: os engenheiros e as engenharias de poder na Primeira República. 1998. 265f. Dissertação (Mestrado em História) - Programa de Pós-graduação em História, Universidade Estadual de Campinas, Campinas, 1998.

CERTEAU, Michel de. A invenção do cotidiano. Artes de fazer. V. 1, $2^{\mathrm{a}}$ ed. ALVES, E. F. (trad.) Petrópolis: Editora Vozes, 1996.

CHARLE, Christophe. Jalons pour une histoire transnationale des universités. Cahiers d'histoire. Revue d'histoire critique [On line], 121, p.21-42, 2013. Disponível em: <http://chrhc.revues.org/3147>. Acessado em: 15 abr. 2016.

CHARTIER, R. A história cultural: entre práticas e representações. Lisboa: DIFEL, 2002.

COHEN, A. M. The shaping of american higher education. San Francisco: Jossey Bass Publishers, 1998.

CUNHA, L. A. A universidade crítica: o ensino superior na República Populista. 2a . ed. Rio de Janeiro: Francisco Alves, 1989.

A universidade temporã: o ensino superior da Colônia à Era Vargas. Rio de Janeiro: Civilização Brasileira/UFC, 1980.

CURY, J. O Plano Nacional de Educação de 1936/1937. In: VII CONGRESSO BRASILEIRO DE HISTÓRIA DA EDUCAÇÃO. Cuiabá, Anais... 2013 p.1-15. Disponível em:

http://sbhe.org.br/novo/congressos/cbhe7/pdf/01-\%20ESTADO\%20E\%20POLITICAS\%20ED UCACIONAIS\%20NA\%20HISTORIA\%20DA\%20EDUCACAO\%20BRASILEIRA/O\%20 PLANO\%20NACIONAL\%20DE\%20EDUCACAO\%20DE\%201936\%20-\%201937.pdf>.

Acessado em: 21 jul. 2017.

DOSSE, F. O Desafio Biográfico: escrever uma vida. SOUZA, G. C. C. S. (trad.). São Paulo: Editora da Universidade de São Paulo, 2009.

ESCOLA POLITÉCNICA. Prof. Dr. Alexandre Albuquerque - 1937-1938. Disponível em : $<$ http://www.poli.usp.br/pt/a-poli/historia/galeria-de-diretores/211-prof-dr-alexandre-albuquerqu e.html >. Acessado em: 28 abr. 2017a.

ESCOLA POLITÉCNICA. Prof. Dr. Rodolpho Baptista de São Thiago - 1928-1930. Disponível em: http://www.poli.usp.br/pt/a-poli/historia/galeria-de-diretores/199-prof-dr-rodolpho-baptista-de-sa o-thiago.html. Acessado em: 25 nov. 2016.

ESCOLA POLITÉCNICA. Prof. Dr. Victor da Silva Freire -1933-1934. Disponível em: http://www.poli.usp.br/pt/a-poli/historia/galeria-de-diretores/201-prof-dr-victor-da-silva-freire-.ht ml. Acessado em: 08 mai. 2017b.

FABRIS, A. A crítica modernista à cultura do ecletismo. Revista Italianística, ano III, n.3, p. 73-84, 1995. 
FARLEY, J. To Cast Out Disease: A History of the International Health Division of Rockefeller Foundation (1913-1951). Cary, US: Oxford University Press, 2003.

FÁVERO, M. L. A. A universidade no Brasil: das origens à Reforma Universitária de 1968. Educar em Revista, v.1, p.17-36, 2006. Disponível em: < http://www.scielo.br/pdf/er/n28/a03n28.pdf> . Acessado em: 02. out.2010.

. Universidade e poder. Análise Crítica/Fundamentos históricos: 1930-1945. Rio de Janeiro: Achiamé. 1980.

FICHER, S. Os arquitetos da Poli: ensino e profissão em São Paulo. São Paulo: FAPESP/EDUSP, 2005.

FRAIZ, P. Arquivos pessoais projetos autobiográficos: o arquivo de Gustavo Capanema. IN: GOMES, A. de C. Capanema: o ministro e seus ministérios. Rio de Janeiro: FGV, 2000, p.73102.

FUNDAÇÃO GETUliO VARGAS. José Carlos de Macedo Soares. Disponível em: < http://cpdoc.fgv.br/producao/dossies/AEraVargas1/biografias/jose carlos de macedo soares $>$. Acessado em: 20 set. 2016.

FUNDAÇÃO GETULIO VARGAS. Francisco Morato. Disponível em: < $\underline{\text { http://cpdoc.fgv.br/sites/default/files/verbetes/primeira-republica/MORATO,\%20Francisco.pdf }}$ $>$. Acessado em: 14 jul. 2017a.

FUNDAÇÃO GETULIO VARGAS. Inácio Manuel Azevedo do Amaral. Disponível em: < http://www.fgv.br/cpdoc/acervo/dicionarios/verbete-biografico/inacio-manuel-azevedo-do-amar all>. Acessado em: 15 jun. 2017b.

GOMES, A. de C. Escrita de si, escrita da História: a título de prólogo. IN: GOMES, A. de C. Escrita de si, escrita da História. Rio de Janeiro: FGV 2004, p.7-25.

GONDRA, J. G. Dossiê: Viagens de educadores, circulação e produção de modelos pedagógicos. Revista Brasileira de História da Educação. Campinas, nº 22, p.13-16, jan./abr. 2010.

GRÊMIO POLYTECHNICO. Rodolpho Baptista de S. Thiago, São Paulo, 1933, p.217-218. Disponível em: $<\underline{\text { http://memoria.poli.usp.br/handle/123456789/1952?discover?rpp=10\&etal=0\&query=Rodolph }}$ o+de+SÃ£o+Thiago\#page/2/mode/1up>. Acessado em: 18 out. 2016.

GUIMARÃES, A. P. F. P.; CHAMON, C. S. Roberto Mange: atuação e proposições para a formação do trabalhador da indústria brasileira (1913-1955). In: III SEMINÁRIO NACIONAL DE EDUCAÇÃO PROFISSIONAL E TECNOLÓGICA (SNEPT)/CEFET-MG. Belo Horizonte. Anais..., $2012 . \quad$ Disponível em: http://www.senept.cefetmg.br/galerias/Anais 2012/GT-04/GT04-002.pdf. Acessado em: 28 jan. 2017.

HEINZ, F. (org.). Por outra história das elites. Rio de Janeiro: FGV, 2006. 
HERSCHMANN, M.; KROPF, S.; NUNES, C. Missionários do progresso: médicos, engenheiros e educadores (1870-1937). Rio de Janeiro: Diadorim, 1996.

INSTITUTO DE ENGENHARIA. História. Disponível em: $<$ https://www.institutodeengenharia.org.br/site/instituto/index/id sessao/18/id texto/14>.

Acessado em: 3 dez. 2016.

KATINSKY, J.; SILVA, H. A. A.; COSTA, S. S. F. Restauro da Faculdade de Medicina da USP: estudos, projetos e resultados. São Paulo: CD.G Casa de Soluções, 2013.

KEMP, A.; EDLER, F. C. A reforma médica no Brasil e nos Estados Unidos: uma comparação entre duas retóricas. História, Ciências, Saúde - Manguinhos, vol. 11(3): p.569-585, set.-dez. 2004.

KESSEL, C. Vanguarda efêmera: arquitetura neocolonial na Semana de Arte Moderna de 1922. Estudos Históricos, Rio de Janeiro, n. 30,p. 110-128, 2002.

KOPP, A. Quando o moderno não era um estilo e sim uma causa. Edi G. de Oliveira tradução. São Paulo: Nobel; Edusp, 1990.

KROPF, S. Sonho da razão, alegoria da ordem: o discurso dos engenheiros sobre a cidade do Rio de Janeiro no final do século XIX e início do século XX. In: HERSCHMANN, M.;__ _; NUNES, C. Missionários do progresso: médicos, engenheiros e educadores (1870-1937). Rio de Janeiro: Diadorim, 1996, p.69-154.

The art of medicine Carlos Chagas: science, health, and national debate in Brazil. Perspectives. Vol 377, n. 21, p.1740-1741, may, 2011.

LACOSTE, J. Y. Apóstolo. In: Dicionário crítico de Teologia. MENEZES, P. (trad.). São Paulo: Paulinas; Edições Loyola, 2004, p.175-179.

LAHUERTA, M. Os intelectuais e os anos 20: moderno, modernista, modernização. In: LORENZO, H. C.; COSTA, W. P. (orgs.) A década de 1920 e as origens do Brasil moderno. São Paulo : UNESP, 1997, p.93-114.

LISSOVSKY, M. \& SÁ, P. S. M. de. O novo em construção: o edifício sede do Ministério da Educação e Saúde Pública e a disputa do espaço arquiteturável nos anos 1930. IN: GOMES, A. de C. Capanema: o ministro e seus ministérios. Rio de Janeiro: FGV, 2000,p. 49- 72.

LOVE, J. A locomotiva: São Paulo na federação brasileira (1889-1937). Vera Alice Cardoso da Silva (trad.). Rio de Janeiro: Paz e Terra, 1982. (Coleção Estudos Brasileiros; v. 57)

MANZALLI, A. P. A História contada com arcos e vãos. Jornal do Campus, 27 out. 2008. Disponível em: <http://www.jornaldocampus.usp.br/index.php/2008/10/a-historia-contada-com-arcos-e-vaos/> . Acessado em: 14 jun. 2017. 
MARINHO, M. G. S. M. C. Arnaldo Vieira de Carvalho: um percurso pela formação intelectual e rede de sociabilidades (1880-1913) ln: .; MOTA, A. (orgs.) Medicina, Saúde e História: Textos escolhidos e outros ensaios (Coleção Medicina, Saúde e História), Vol. VI. São Paulo: USP/ UFABC/Casa de Soluções e Editora, 2014, p.11-32.

Difundir a ciência, modernizar a medicina. Pactos para uma nova racionalidade médica: São Paulo, 1916-1925. In: .; MOTA, A. Caminhos e trajetórias da

filantropia científica em São Paulo. A Fundação Rockefeller e suas articulações no ensino, pesquisa e assistência para a Medicina e Saúde (1916-1952). São Paulo: USP, Faculdade de Medicina/ UFABC/ Casa de Soluções e Editora, 2013a. (Coleção Medicina, Saúde e História)

Elites em negociação: breve história dos acordos entre a Fundação Rockefeller e a Faculdade de Medicina de São Paulo (1916-1931). In: ; MOTA, A. Caminhos e trajetórias da filantropia científica em São Paulo. A Fundação Rockefeller e suas articulações no ensino, pesquisa e assistência para a Medicina e Saúde (1916-1952). São Paulo: USP, Faculdade de Medicina/ UFABC/ Casa de Soluções e Editora, 2013b.(Coleção Medicina, Saúde e História)

Norte Americanos no Brasil: Uma história da Fundação Rockefeller na Universidade de São Paulo (1934-1952). Campinas, SP: Autores Associados, São Paulo: Universidade São Francisco, 2001.

MARINHO, M. G. S. M. C.; MOTA, A. Caminhos e trajetórias da filantropia científica em São Paulo. A Fundação Rockefeller e suas articulações no ensino, pesquisa e assistência para a Medicina e Saúde (1916-1952). São Paulo: USP, Faculdade de Medicina/ UFABC/ Casa de Soluções e Editora, 2013.(Coleção Medicina, Saúde e História)

(orgs.). Trajetória da Faculdade de Medicina da Universidade de São Paulo: aspectos históricos da “Casa de Arnaldo”. São Paulo: Casa de Soluções e Editora, 2012.

MELLO, J. Da arqueologia portuguesa à arquitetura brasileira. Revista do IEB, n. 43 set. 2006, p.60-98.

MENDONÇA, A. W. P. C. Anísio Teixeira e a universidade de educação. Rio de Janeiro: EdUERJ, 2002.

A universidade no Brasil. Revista Brasileira de Educação. 500 anos de educação escolar. SAVIANI, D. et al.(orgs.), n¹4, p. 131-150, mai.jun./jul./ago., 2000 . Disponível em http://www.anped.org.br/rbe/rbedigital/RBDE14/RBDE14_09_ANA_WALESKA_P_C _MENDONCA.pdf $>$. Acessado em 02. out. 2012.

Universidade e formação de professores: uma perspectiva histórica. Cadernos de Pesquisa. São Paulo, n. 90., p.36-44, ago.1944.

MOTA, A. Arnaldo Vieira de Carvalho: história e memória de um médico ilustre. In: MARINHO, M. G.S. M. C.; . (org.) Medicina, Saúde e História: Textos escolhidos e outros ensaios (Coleção Medicina, Saúde e História), Vol. VI. São Paulo: USP/ UFABC/Casa de Soluções e Editora, 2014, p.33-56. 
Tropeços da Medicina Bandeirante: medicina paulista entre 1892-1920. São Paulo: EDUSP. 2005.

MUSEU HISTÓRICO DA FACULDADE DE MEDICINA DA UNIVERSIDADE DE SÃO PAUlO. Fundos OPCM - Ovídio Pires de Campos (1884-1950). Disponível em: $<$ http://www.pesquisadores.museu.fm.usp.br/index.php/ov-dio-pires-de-campos1884-1950;isad>. Acessado em: 18 de outubro de 2016.

NERY, A. C. B. Embates no campo educacional: a Sociedade de Educação de São Paulo (1922-1931). In: 24a REUNIÃO ANUAL DA ANPED. Caxambu. Anais..., 2001. Disponível em: <www.anped.org.br/sites/default/files/gt02 06.pdf>. Acessado em: 13 fev. 2017.

NUNES, C.; CARVALHO, M. M. C. Historiografia da educação e fontes. In: GONDRA, José Gonçalves. Pesquisa em história da educação no Brasil. Rio de Janeiro: DP\&A, 2005, p.40-62.

NUNES, C. Cultura escolar, modernidade pedagógica e política educacional no espaço urbano carioca. In: HERSCHMANN, M.; KROPF, S.; Missionários do progresso: médicos, engenheiros e educadores (1870-1937). Rio de Janeiro: Diadorim, 1996, p. 155-224.

PAZIANI, R. R. Versões, reversões, controvérsias: o desafio biográfico. Revista USP. n92,p. 190-200, 2012.

PETITJEAN, P. As missões universitárias francesas na criação da Universidade de São Paulo (1934-1940). In: HAMBURGUER, A. I. et al.(Org.). A ciência nas relações Brasil-França (1850-1950). São Paulo: Edusp/ Fapesp, 1996a, p.259-330.

Entre Ciência e Diplomacia: A organização da Influência Científica Francesa na América Latina. In: HAMBURGUER, A. I. et al.(Org.). A ciência nas relações Brasil-França (1850-1950). São Paulo: Edusp/Fapesp, 1996b, p.89-120.

PINTO, G. A.; BUFFA, E. Arquitetura e educação: câmpus universitários brasileiros (online). São Carlos: EdUFSCAR, 2009.

RANIERI, N. B. S. (org.). Autonomia universitária na USP: 1934-1969. Vol. I. TOBA, M. M.(coord.). São Paulo: EDUSP, 2005.

ROTHEN, J. C. A universidade brasileira na Reforma Francisco Campos de 1931. Revista Brasileira de História da Educação. n.17, p. 141-160, mai/ago. 2008.

SANTOS, M. C.; MOTA, A. São Paulo 1932: memória, mito e identidade. São Paulo: Alameda, 2010.

SCHMIDT, B. B. O gênero biográfico no campo do conhecimento histórico: trajetória, tendências e impasses atuais e uma proposta de investigação. Anos 90: Revista do Programa de Pós-Graduação em História. Porto Alegre. Nº6 p. 165-192, dez., 1996. 
SCHWARTZMAN, S.; BOMENY, M. H. B.; COSTA, V. M. R. Tempos de Capanema. Rio de Janeiro: Paz e Terra, São Paulo: EDUSP, 1984.

SETTON, M. G. J. Rotary Club: habitus, estilo de vida e sociabilidade. São Paulo: Annablume, 2004.

SILVA, M. C. EE. Cel. Fernando Prestes: arquivo permanente, memória e história. 2007. 91f. Dissertação (Mestrado em Educação),Universidade de Sorocaba-Uniso, Sorocaba, 2007.

SIQUEIRA, R. M. A matemática e seus usos controlados: engenheiros matemáticos positivistas do Brasil Imperial ao Republicano. 167f. 2017. Tese (Livre Docência). No prelo.

SOUZA, R. F. Templos de civilização: a implantação da escola primária graduada no estado de São Paulo (1890-1910), São Paulo: Fundação Editora da UNESP, 1998.

STEPAN, N. L. The National and the International in Public Health: Carlos Chagas and the Rockefeller Foundation in Brazil, 1917-1930s. Hispanic American Historical Review [online], vol. 91(3), aug., p.469-502, Duke University Press, 2011.

TAFURI, M. Projecto e utopia: arquitectura e desenvolvimento do capitalismo. JARDIM, C; NOGUEIRA, E. (trad.) Lisboa: Presença. 1985.

TAUnAY, A. D’E. Dr. Antônio de Cerqueira César. Grêmio Polytechnico. São Paulo, 1915. Disponível em: $<$ http://memoria.poli.usp.br/handle/123456789/2106?discover?rpp=10\&etal=0\&query=Dr.+ Antonio+de+Cerqueira+C\%C3\%83\%C2\%A9sar\#page/1/mode/1up $>$. Acessado em: 20 jun. 2016.

TELAROLLI Jr., R. Poder e saúde: as epidemias e a formação dos serviços de saúde em São Paulo. São Paulo: Editora da Universidade Estadual Paulista, 1996.

THELIN, J. A history of American higher education. Baltimore: The Johns Hopkins University Press, 2004.

THEODORO, J. São Paulo de Ramos de Azevedo: da cidade colonial à cidade romântica. Anais do Museu Paulista. São Paulo. N. Sér. v.4, p.201-208, jan./dez. 1996.

UHLE, A. B. Comunhão Leiga: O Rotary Club no Brasil. 1991, 353 p. Tese ( Doutorado em Educação).Faculdade de Educação, Universidade Estadual de Campinas, Campinas, 1991.

UNIVERSIDADE DE SÃO PAULO. Diretrizes para apresentação de dissertações e teses da USP: Parte I (ABNT). 3 ed. rev., amp., mod., FUNARO, V. M. B. O. (coord.). São Paulo: SIBIUSP, 2016 (Cadernos de Estudos; 9)

VIEIRA, C. E. Erasmo Pilotto: identidade, engajamento político e crenças dos intelectuais vinculados ao campo educacional brasileiro. In: LEITE, J. L..; ALVES, Cláudia (org.). Intelectuais e história da educação no Brasil: poder, cultura e políticas. Vitória: EDUFES, 2011, p.25-54. 
WACHOWICZ, R. C. Universidade do mate: história da UFPR. Curitiba: APUFPR, 1983

WATKIN, D. A History of Western Architecture. 4 ed. Londres: Laurence King Publishing, 2005.

WEINSTEIN, B. (Re)formação da classe trabalhadora no Brasil (1920-1964). São Paulo: Cortez, 2000.

ROCKEFELLER ARCHIVE CENTER. Abraham Flexner. 100 years -The Rockefeller Foundation. Disponível em: $<$ http://rockefeller100.org/biography/show/abraham-flexner $>$. Acessado em: 26 jan.2017.

YOURCENAR, M. Memórias de Adriano. 2.ed., CALDERARO, M. (trad). Rio de Janeiro: Nova Fronteira, 1980.(Coleção Grandes Romances) 